\author{
Universidade de São Paulo \\ Instituto de Física \\ Instituto de Química \\ Instituto de Biociências \\ Faculdade de Educação
}

\title{
Planejamento e Plano de Ensino de Química para o Ensino Médio: concepções e práticas de professores em formação contínua
}

\section{Marcela Gaeta de Andrade}

Orientadora: Profa. Dra. Carmen Fernandez

Dissertação de Mestrado apresentada ao Instituto de Física, ao Instituto de Química, ao Instituto de Biociências e à Faculdade de Educação da Universidade de São Paulo, para a obtenção do título de Mestre em Ensino de Ciências.

São Paulo 
Dê-me, Senhor, agudeza para entender, capacidade para reter, método e faculdade para aprender, graça e abundância para falar. Dê-me, Senhor, acerto ao começar, direção ao progredir e perfeição ao concluir.

São Tomás de Aquino 
À minha mãe, Maria Helena. Seu exemplo de dedicação à educação foi minha inspiração para seguir nesta profissão. Sua força como mulher incentiva-me a querer sempre mais. E seu amor e apoio em todas as horas não me deixam desistir frente aos maiores desafios. Meu amor eterno. 


\section{AGRADECIMENTOS}

A Deus por me dar saúde e serenidade para atingir meus objetivos.

À Profa ${ }^{a}$ Dra . Carmen Fernandez pela orientação primorosa e pelo companheirismo durante este percurso.

À Pro ${ }^{a}$. Dra . Paola Corio pela colaboração e palavras de incentivo nos momentos de desespero.

Ao Prof ${ }^{\circ}$. Dro. José Cerchi Fusari e à Profa ${ }^{a}$ Dra . Jesuína Pacca pelas contribuições no Exame de Qualificação.

À Prof ${ }^{a}$. Dra ${ }^{a}$. Marcela Fejes pela acolhida no LabVirt e a todos os participantes deste projeto.

À Cindy Coelho Valadão, aluna de iniciação científica, pela colaboração na realização deste trabalho.

Aos professores que se dispuseram para a pesquisa.

Ao meu marido, Renato, pelo amor, respeito e companheirismo e às nossas filhas, Fernanda e Fabiana, pela compreensão nas horas em que estive ausente e pelo carinho nas horas presentes.

Aos meus familiares, que sempre torceram pelo meu sucesso e que estão felizes por mais esta conquista.

$\mathrm{E}$ a todos aqueles que, direta ou indiretamente, contribuíram para que este meu sonho se realizasse. 


\section{RESUMO}

Dentre os muitos e bem conhecidos problemas relacionados ao ensino de Ciências, a falta de planejamento dos professores vem contribuindo para agravar ainda mais esses problemas. Na prática escolar existe grande dificuldade em compreender a necessidade de um processo de planejamento e de torná-lo real. Atualmente o planejamento é rejeitado por professores que por obrigação se limitam a elaborar seu plano burocraticamente, apenas para atender as exigências da Instituição.

Esta pesquisa buscou investigar as concepções sobre planejamento e elaboração do plano de curso de sete professores de Química de escolas estaduais de São Paulo que participaram do Projeto Laboratório Didático Virtual (LabVirt) desenvolvido pela Escola do Futuro da Universidade de São Paulo. Buscou investigar também a possibilidade de uma ação de formação contínua ter efetividade prática na promoção de mudanças significativas na elaboração dos planos de curso destes professores, enfatizando não apenas os conteúdos, mas também os objetivos, os métodos, os recursos e a avaliação.

Os dados desta pesquisa foram coletados na forma de questionários, entrevistas e planos de curso pré e pós-projeto e organizados em mapas cognitivos por permitem uma visão idiossincrática de cada indivíduo.

Os resultados obtidos sugerem que os professores entendem o processo de planejamento como necessário para organizar os conteúdos conceituais que serão ensinados durante o ano. Seus planos de curso seguem o modelo padrão estabelecido pela maioria das escolas (objetivo, conteúdo, metodologia e avaliação) e não refletem o "quê fazer" do professor.

As atividades desenvolvidas no LabVirt pouco contribuíram para modificações nos planos de curso, na medida que os planos elaborados pós-projeto são praticamente idênticos aos do pré-projeto. Apesar disso, todos assumem que o fato de ter um plano de aulas bem organizado, facilita e orienta a prática docente mostrando então que perceberam a importância do planejamento no seu dia-a-dia.

Palavras-chave: ensino de química, planejamento, formação contínua de professores. 


\begin{abstract}
Among the many and well-known problems related to science education, the poor preparation of teaching plannings make these problems worse. Most in-service teachers have difficulties to understand the necessity of the planning process, and to bring it to reality. In general, teachers reject planning, for they consider it only as an imposition of the school's bureaucratic structure.

The aim of this research was to investigate the conceptions on planning and the elaboration of course plans of seven Chemistry teachers working in public schools from the state of São Paulo, and which took part in the Virtual Didactic Laboratory Project (LabVirt) developed by the "Escola do Futuro" of the University of São Paulo. Another aim was to investigate the effects of an in-service teacher education action designed to promote significative changes in the elaboration of course plans, which should focus not only contents, but also objectives, methods, resources and assessment.

Data of this research consisted in answers to questionnaires, interviews and plannings which were collected before and after the LabVirt activities. Data were organized in cognitive maps, which allowed an idiossincratic view the participants.

The results suggested that the teachers understand the planning process as necessary to organize the conceptual contents that will be taught during the year. Their annual plannings follow the established pattern in most schools, and do not properly reflects the teachers' practices.

The activities developed in the LabVirt project brought few contributions to the modification of course plans, since the plans elaborated after the project activities were practically the same those made before them. However, most teachers recognized the importance of a well-elaborated class plan. The importance of planning to their everyday practice seemed to have been assimilated by the teachers.
\end{abstract}

Key-words: chemical education, planning, in-service teacher education 


\section{SUMÁRIO}

APRESENTAÇÃO

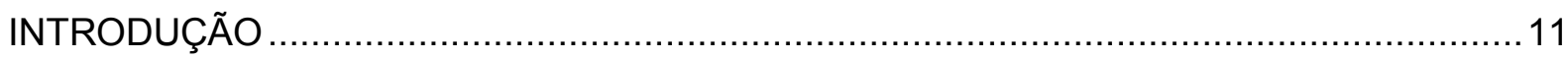

1. FORMAÇÃO CONTÍNUA DE PROFESSORES DE QUÍMICA ….................................18

2. CONSIDERAÇÕES TEÓRICAS SOBRE O PLANEJAMENTO DE ENSINO E SUA

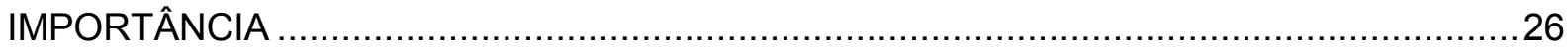

2.1. Planejamento

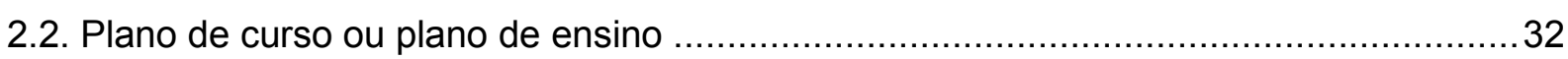

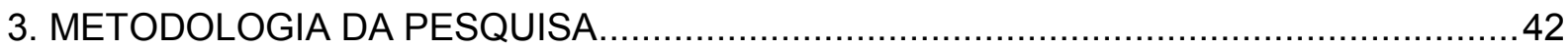

3.1. O contexto: Projeto Laboratório Didático Virtual Química - LabVirt.............................42

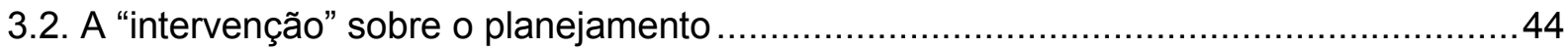

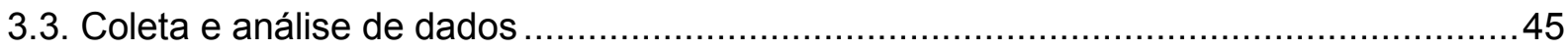

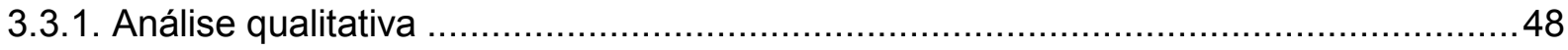

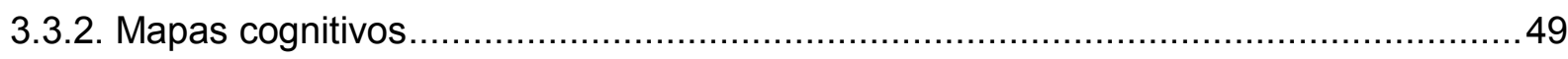

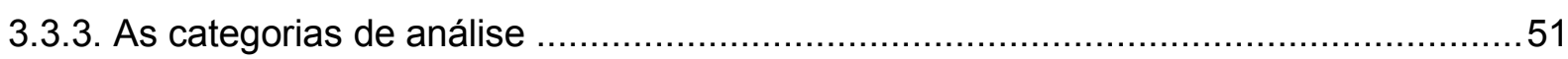

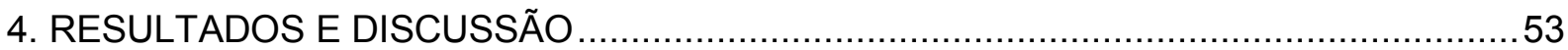

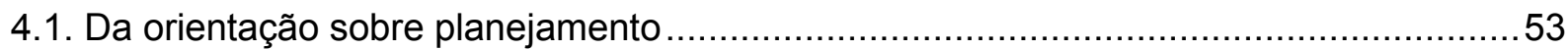

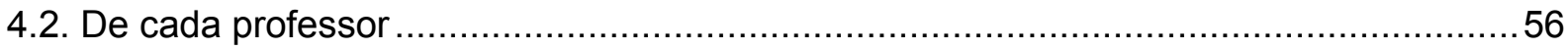

4.2.1. Professor $P 1$

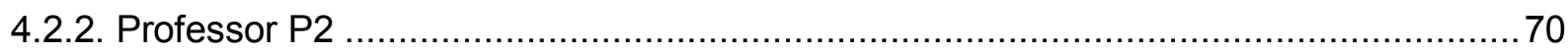

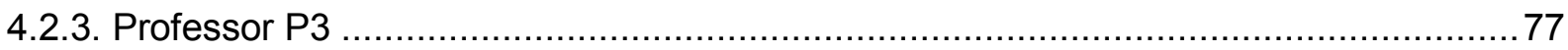

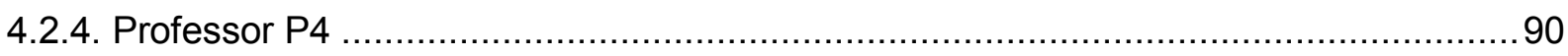

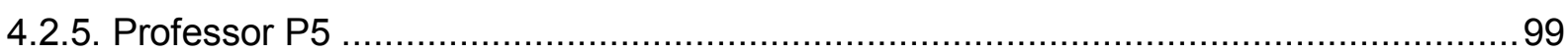

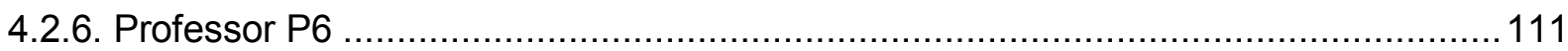

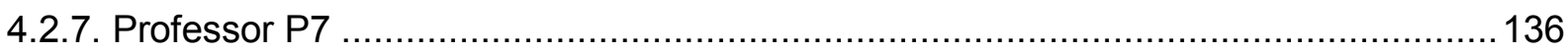

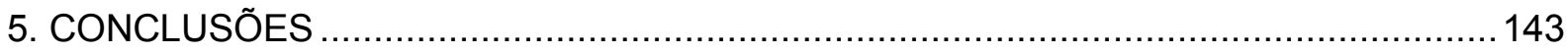


ANEXOS 156

Anexo 1. Planejamento geral de unidades didáticas - LabVirt 156

Anexo 2. Roteiro orientador para a elaboração do plano de ensino e aula. 160

Anexo 3. Transcrição da intervenção sobre planejamento 172

Anexo 4. Questionários pré-projeto 194

Anexo 5. Transcrição das entrevistas. 206

Anexo 6. Questionários pós-projeto 270 


\section{APRESENTAÇÃO}

Antes de iniciarmos nossa conversa sobre este estudo, apresento minha trajetória e os anseios que levaram a interessar-me pelo processo do planejamento e seus produtos.

Em 1998, após ter concluído o bacharelado em Química, ingressei para o magistério em escolas públicas estaduais de São Paulo como professora de Química do Ensino Médio, cursando ainda a licenciatura em Química. Posso dizer que a escolha pelo magistério não poderia ter sido diferente já que venho de uma família de educadores e por isso convivo neste ambiente desde muito pequena e pelo qual sempre me interessei.

No início do ano letivo dessa escola todos os professores tiveram que elaborar o planejamento da sua disciplina (assim denominavam o documento) e, como eu nunca havia elaborado um, não sabia como fazê-lo. Para tanto, utilizei como modelo os planejamentos de anos anteriores. Os conteúdos que seriam ensinados, copiei do livro didático; os objetivos de documentos oficiais (LDB, Parâmetros Curriculares, etc.); e os outros tópicos (estratégias, avaliação e recursos), compartilhei com os meus pares. Tendo o documento pronto e formatado em formulário pré-estabelecido pela escola, entreguei-o à coordenação pedagógica e a sensação de "trabalho cumprido" se estabeleceu.

No decorrer do ano, percebi que todo aquele conteúdo pré-estabelecido em meu planejamento jamais seria alcançado. Isto se tornaria impossível por vários motivos que não foram considerados por mim no momento de sua elaboração, como, por exemplo, diversidade de níveis cognitivos dos alunos, número de aulas, quantidade de conceitos a serem ensinados/aprendidos, contexto sócio-econômico da escola, etc.

A partir dessa experiência e de uma curta discussão sobre planejamento na Licenciatura na disciplina de Prática de Ensino, nos próximos anos o planejamento para mim passou a ser um momento de maior reflexão e discussão sempre a partir da realidade encontrada. A elaboração não só do planejamento, mas de um plano de aula, tornou-se necessária à minha prática, caso contrário o improviso tomaria conta das minhas aulas. Em 2003, ao assumir o cargo de Assistente Técnico-Pedagógico da Área

${ }^{1}$ Assistente Técnico-Pedagógico: Conforme a Resolução SE - 12, de 11-2-2005, é um docente que representa uma área da Educação Básica na Oficina Pedagógica e tem como atribuições elaborar e implementar o Plano de Trabalho da Oficina Pedagógica, de forma articulada com o da Diretoria de Ensino; participar da formulação, do acompanhamento e da avaliação das atividades de natureza pedagógica presentes no Plano de Trabalho da Diretoria de Ensino; identificar as demandas de formação continuada, a partir da análise de indicadores, 
de Ciências da Natureza na Diretoria de Ensino (D.E.) Sul- $1^{2}$, deparei-me com a tarefa de orientar pedagogicamente os professores desta área (Química e Biologia). Para isso eram oferecidas mensalmente Orientações Técnicas ${ }^{3}$ a esses professores de Ensino Médio que trabalhavam nas escolas dirigidas pela D.E. Sul-1. Como estratégia de trabalho para essas orientações, pensei em partir do planejamento que cada professor

propondo ações voltadas para as prioridades estabelecidas; desenvolver, dentro de sua área específica de atuação, ações descentralizadas de formação continuada, de acordo com o Plano de Trabalho da Oficina Pedagógica; prestar assistência e apoio técnico-pedagógico às equipes escolares no processo de elaboração e implementação da proposta pedagógica da escola; estimular a utilização de novas tecnologias na prática docente, nas diferentes áreas do currículo, favorecendo a sua apropriação; orientar as equipes escolares para a utilização e otimização dos ambientes de aprendizagem e dos equipamentos e materiais didáticos disponíveis; promover ações que possibilitem a socialização de experiências pedagógicas bem-sucedidas; divulgar e estimular o acesso dos professores ao acervo da Oficina Pedagógica e auxiliá-los na seleção dos materiais disponíveis, incentivando-os a produzir outros materiais pedagógicos; desenvolver ações a partir de demandas específicas das escolas e ou propostas pelos órgãos centrais.

2 Diretoria de Ensino: órgão da Secretaria de Estado da Educação de São Paulo responsável por um determinado número de Escolas Estaduais e Particulares de uma região que tem como atribuições executar a política educacional da Secretaria da Educação; acompanhar o desenvolvimento do ensino; prestar assistência técnico-administrativa aos Diretores de Escola de sua área de atuação; controlar e avaliar as atividades administrativas da sua área de jurisdição; supervisionar atividades pedagógicas e de orientação educacional; colaborar na difusão e implementação das normas pedagógicas emanadas dos órgãos superiores; avaliar os resultados do processo ensino-aprendizagem; analisar dados relativos à Diretoria e elaborar alternativas de solução para os problemas específicos de cada nível e modalidade de ensino; assegurar a retroinformação ao planejamento curricular; opinar quanto à necessidade e oportunidade de treinamento para os recursos humanos específicos da Diretoria; dar pareceres, realizar estudos e desenvolver outras atividades relacionadas com a supervisão pedagógica e de orientação educacional.

A Diretoria de Ensino Sul-1 atua em 86 escolas estaduais distribuídas nos Distritos de Campo Grande, Campo limpo, Cidade Ademar, Jabaquara, Pedreira, Santo Amaro e Vila Andrade.

Orientações Técnicas: encontros mensais de 4 horas dos Assistentes TécnicoPedagógicos com diretores, coordenadores pedagógicos ou professores da Rede Estadual de Ensino a fim de orientá-los quanto às diretrizes do Ministério da Educação e da Secretaria de Estado da Educação de modo a subsidiar o trabalho na Unidade Escolar. 
havia elaborado para a sua disciplina por considerar que este refletiria em parte a sua prática em sala de aula.

Sendo assim, solicitei aos professores que trouxessem seus planejamentos e a grande maioria disse não estar com eles em mãos porque os haviam entregado para a coordenação pedagógica da escola.

Minha nossa! Os professores elaboram um documento que, na minha opinião, é imprescindível para a sua prática docente diária, e não possuem ao menos uma cópia para orientar o seu trabalho? Esses professores são capazes de lembrar o que planejaram para um ano letivo inteiro para cada série em que lecionam? Como eles organizam sua prática? O que eles fazem em suas aulas? Como será que eles as planejam? Ou melhor, será que eles as planejam?

A Oficina Pedagógica ${ }^{4}$ da D.E. Sul-1 tinha sob minha orientação professores de 50 escolas das 3528 escolas com Ensino Médio da Secretaria de Estado da Educação e, tomando por base esta realidade, passei a refletir sobre quantos professores na Rede Estadual de Ensino estariam trabalhando dessa forma. Poderia existir uma maneira de envolvermos esses professores no processo de planejamento de forma mais efetiva e reflexiva?

Essas dentre outras tantas perguntas não pararam de me atormentar. Então, ao ingressar neste programa de mestrado em Ensino de Ciências em 2004, estava muito claro qual seria meu objeto de pesquisa: o planejamento. E considerando minha formação específica, focaria nos planejamentos elaborados pelos professores de Química. Isso mesmo, "planejamento", porque até então não considerava que o documento pronto era o plano de curso e que o planejamento era um processo para a elaboração desse documento.

Espero então com este estudo entender como o plano de ensino é elaborado por alguns professores de Química, quais as concepções em que se baseiam e se a formação contínua contribui para a o enriquecimento desses professores sobre este tema a ponto de modificar sua postura no momento de sua elaboração e, conseqüentemente, a melhoria do resultado final.

${ }^{4}$ Oficina Pedagógica: de forma articulada com a Equipe de Supervisão da Diretoria de Ensino, desempenha papel relevante na implementação das ações de formação continuada e dos projetos voltados para a melhoria da qualidade do ensino e da aprendizagem dos alunos da rede estadual. 


\section{INTRODUÇÃO}

Muitas críticas são dirigidas à escola e à educação escolar, principalmente no que diz respeito ao seu "tradicionalismo" expresso pela presença de um currículo fechado, elaborado a partir de livros didáticos e por métodos de ensino baseados unicamente na transmissão de conhecimentos. Essas preocupações são antigas e para muitas dessas críticas várias propostas de melhoria vêm sendo sugeridas por pesquisadores da área.

Como exemplo, podemos citar o Movimento da Escola Nova, idealizado aqui no Brasil na década de 30 por Lourenço Filho, Anísio Teixeira e Fernando de Azevedo, que baseando-se nos ideais de John Dewey propunha que o aprendizado escolar ao invés de ser organizado a partir de uma hierarquização de matérias deveria ser organizado a partir da reconstrução das experiências o que promoveria uma aprendizagem auto-ativa, onde o aluno resolveria problemas por meio de recursos experimentais ou materiais ou do seu comportamento reflexivo. Isso foi traduzido nas práticas pedagógicas do escolanovismo como "aprender é aprender a aprender" (CAMPOS e SHIROMA, 1999).

Caminhando para os anos 90, a última reforma educacional brasileira (BRASIL, 1996) retomou a preocupação com o currículo a ser ensinado e procurou estabelecer diretrizes que se contrapunham a essa situação criticada propondo mudanças que permeiam, entre outros focos, a centralidade do indivíduo e do processo de aprendizagem, assinalando então as competências finais a serem adquiridas pelos alunos, deixando livre, a cargo da escola e conseqüentemente do professor, a tarefa de selecionar os conteúdos necessários para atingir tais competências.

Considerando então que um dos princípios e fins da Educação Nacional é "a educação, dever da família e do Estado, inspirada nos princípios de liberdade e nos ideais de solidariedade humana, tem por finalidade o pleno desenvolvimento do educando, seu preparo para o exercício da cidadania e sua qualificação para o trabalho" (Artigo 2, BRASIL, 1996), e todas as críticas advindas de anos de história da Educação, os Parâmetros Curriculares Nacionais para o Ensino Médio - PCNEM (BRASIL, 1999) divulgados pelo Ministério da Educação a fim de difundir os princípios da reforma do ensino em nível médio, propuseram um novo perfil para o currículo, apoiado em competências básicas para a inserção de nossos jovens na vida adulta buscando com isso dar significado ao conhecimento escolar, evitar a compartimentalização do conhecimento e incentivar o raciocínio e a capacidade de aprender.

Com isso podemos pensar como sendo função intrínseca da escola auxiliar cada sujeito, tanto individual como coletivamente, a ser capaz de pensar para inovar. Só que para inovar é preciso conhecer, e só tem condições de conhecer, neste mundo de produção de conhecimento, quem aprendeu a aprender pelas próprias mãos e que 
também por idéia própria sabe pensar. Aprender a aprender e saber pensar são, pois, as habilidades a procurar desenvolver em cada sujeito se o que se quer é educar para um mundo de oportunidades mais equalizadas (DEMO, 1997).

Para os PCNEM (BRASIL, 1999), a formação do aluno deve ter como alvo principal a aquisição de conhecimentos básicos, a preparação científica e a capacidade de utilizar as diferentes tecnologias relativas às áreas de atuação, devendo este portanto ser capaz de pesquisar, buscar informações, analisá-las e selecioná-las tornando-se então responsável pelo seu aprendizado. Essa visão se opõe à formação específica e ao exercício da memorização que por muito tempo prevaleceram em nossas escolas e que vêm sendo criticadas desde a década de 30 .

Apesar dessas propostas já estarem inseridas no contexto escolar há 11 anos, seja como documento, como discurso, ou até mesmo como prática, percebemos que pouco dessas propostas realmente se efetivaram, pois ainda deparamo-nos com uma escola desvinculada da vida, abstrata, formalista, autoritária, passiva, etc.

Inserido nesse contexto está o ensino de Ciências que, apesar de pesquisas indicarem que cientistas e educadores concordam sobre os objetivos maiores da área pensar lógica e criticamente (KRASILCHIK, 1987) - vem apresentando resultados insatisfatórios frente às orientações curriculares atuais onde propõem que, vivendo num mundo científico e tecnológico de rápidas mudanças, a Ciência, ao ser ensinada durante a educação básica, deve preparar para a vida, qualificar para a cidadania, e capacitar para o aprendizado permanente, em eventual prosseguimento nos estudos ou diretamente no mundo do trabalho (BRASIL, 2002).

Apesar da comunidade de educadores em Ciências dispor de um corpo de conhecimentos que aborda eficazmente os problemas que apresenta o processo de ensino-aprendizagem das Ciências, Copello Levi e Sanmartí Puig (2001), ao analisarem como se ensinam as Ciências no Brasil, afirmam que existe uma profunda distância entre as propostas curriculares que costumam ser conseqüência de teorias didáticas surgidas da investigação educativa e de planejamentos sócio-econômicos, e as ações que realmente se efetivam nas escolas.

Muitos são os motivos apontados para a não efetivação dessas propostas. Nas Orientações Curriculares do Ensino Médio (BRASIL, 2004) foram atribuídos fatores políticos, quando não ocorreu uma discussão entre os segmentos da comunidade educacional; fatores pedagógicos, devido às condições de ensino e à divergência conceitual entre os documentos e os professores quanto à noção de competência; e fatores sociais, que ao separar o Ensino Médio da educação profissional ampliou o tempo de formação para ingresso do jovem na vida produtiva desencadeando a evasão escolar devido à precariedade na condição de oferta desses cursos e à dificuldade 
financeira, forçando-o a inserir-se no mercado de trabalho, mesmo antes de ter concluído sua Educação Básica e portanto sem nenhum preparo para encarar os desafios de uma nova profissão.

Para Gil-Pérez e Carvalho (2000), isto se justifica pela persistência de uma visão bastante simplista das mudanças curriculares de que basta apresentar aos professores as novas propostas, fundamentadas em investigações rigorosas, para que estas propostas sejam aceitas e aplicadas.

Os professores normalmente não são ouvidos, respeitados e tão pouco atendidos em suas necessidades para a elaboração dessas propostas. As reformas geradas em gabinetes atropelam violentamente educadores, educandos e a própria comunidade na qual a escola está inserida.

Maldaner (2000) aponta que, pela falta de compromisso com as orientações curriculares produzidas e por não se sentirem valorizados em sua profissão, os professores estão fora do processo de implementação das pretendidas melhorias, em caminho inverso ao que recomendam estudos e pesquisas pedagógicos, e por isso nada muda significativamente.

Porém não podemos pensar somente nas políticas públicas como o eixo estruturador da ação docente. Uma reforma curricular apenas não dará conta de resolver todos os problemas educacionais que foram germinando ao longo de tantos anos. A concepção do professor sobre o processo de ensino-aprendizagem, seu objetivo educacional, o conhecimento de sua disciplina e de outros assuntos relacionados à educação necessários para sua prática, são alguns dos fatores que influenciam, e muito, essa ação.

No Ensino de Ciências os resultados insatisfatórios quanto à educação tecnológica básica e a compreensão do significado da ciência devem-se ainda à vivência do professor em dois contextos, como aluno e como docente, pois se considera que os professores de ciências têm concepções sobre a ciência e sobre a forma de aprendê-la e ensiná-la, fruto de seus anos de escolaridade, que estão profundamente arraigadas (MELLADO, 1996).

Além disso, ao considerarmos a complexidade de fatores que norteiam a ação docente e ao imaginarmos que no Brasil há uma imensa desigualdade estrutural nos setores educacional e social, além de outros, podemos pensar em diferentes "professores", em diferentes "alunos" e em diferentes "ambientes educacionais" que compõem nossa Educação e que estão sujeitos a uma mesma legislação numa tentativa de equalizar a educação nacional. Neste contexto, não poderíamos pensar em outra realidade que não numa diversidade quanto à qualidade na formação desses jovens. 
Diante de tantas razões para a atual situação do ensino brasileiro, decidimos focar nosso estudo no planejamento escolar vivenciado pelo professor. Apesar de existirem muitos estudos, desde a década de 70 , sobre os processos de planejamento, poucos são dedicados especificamente ao ensino de Ciências (SÁNCHEZ e VALCÁRCEL, 1999).

A importância do plano de ensino para a prática docente se justifica na medida que este fornece parâmetros para a ação em sala de aula e é concebido como um meio para facilitar e viabilizar a democratização do ensino (FUSARI, 1990). Assim como Goodson (1997), entendemos que ao conceber e planejar a ação educativa, o professor expõe suas crenças e indica as formas e concepções do currículo acreditando que este trabalho será desenvolvido.

Junto a isso verificamos que após a divulgação dos PCNEM (BRASIL, 1999), onde um novo currículo educacional admitido como aberto e flexível foi proposto, esse passou a ser o principal referencial teórico nas Orientações Técnicas oferecidas aos diretores, coordenadores pedagógicos ou professores nas Diretorias de Ensino, mais especificamente nas Oficinas Pedagógicas. Como conseqüência, as Unidades Escolares estariam sendo influenciadas, ou não, pelas concepções de educação fornecidas por esse documento, ao elaborarem o seu Plano Político Pedagógico e o plano de ensino dos professores.

Seria ingenuidade de nossa parte acreditar que as Orientações Técnicas por si só seriam suficientes para mudar radicalmente a prática docente dos educadores. São muitos os determinantes que os condicionam a serem mais "reprodutores" do que "sujeitos" no processo de ensino-aprendizagem. Contudo, devemos ressaltar que nas Orientações Técnicas sobre os Parâmetros foi destacado que tanto a Unidade Escolar como os professores poderiam ter um papel ativo na elaboração de seus planos, o que possibilitaria a autonomia de cada professor, libertando-os de reproduzir os programas curriculares pré-estabelecidos por livros didáticos.

Acontece que a profissão docente ainda sofre influência do processo da proletarização. Há uma tendência para separar a elaboração de currículos e de programas da sua concretização pedagógica, provocando uma degradação do seu estatuto e retirando-lhes margens importantes de autonomia profissional (NÓVOA, 1995).

Almeida (1999) indica a presença de limites significativos à autonomia e ao controle profissional dos professores na medida que estes trabalham em instituições burocráticas e hierarquizadas, onde ocupam posições subordinadas e estão sujeitos a variadas formas de controle burocrático e administrativo.

Uma delas é a de que o professor cumpra sua tarefa de ensinar todo o conteúdo de sua disciplina sem a possibilidade de discutir possíveis inovações com seus pares, limitando-se assim a seguir o currículo pré-estabelecido pelos livros didáticos variando 
muito pouco sua metodologia a cada ano de magistério, deixando de considerar, então, o contexto escolar a que está submetido.

O professor não é um técnico que aplica instruções, e sim um construtivista que processa informações, toma decisões, gera rotinas e conhecimento prático, e possui crenças que influem em sua atividade profissional (MELLADO, 1996).

Devemos ressaltar que o primeiro e mais importante objetivo do planejamento das disciplinas, para uma situação de ensino, deveria ser de desenvolver uma ação eficaz de ensino-aprendizagem. Portanto, se o professor planejar o seu ensino, deve ser para ele e para seus alunos, em primeiro lugar. Esse plano passa a ser um instrumento de uso pessoal entre professores e alunos. E só em segundo lugar o plano poderá servir a outros setores da escola, para cumprir certas obrigações e exigências administrativas ou burocráticas (MENEGOLLA e SANT'ANNA, 2003).

Mas, infelizmente, não é o que se verifica em geral na Semana de Planejamento (2 dias e meio normalmente) no início de cada ano letivo nas Unidades Escolares Estaduais. Neste momento, o corpo diretivo, os coordenadores pedagógicos e todos os professores da Unidade se reúnem (ou deveriam se reunir) para discutir os objetivos educacionais da instituição, seu Plano Político Pedagógico, seus projetos e enfim para elaborar os planos de curso de cada professor que devem ser entregues até uma data estabelecida. Essa proposta enfatiza e fortalece a idéia arcaica de que primeiro só planejamos, depois só executamos e depois só avaliamos, sendo uma sistemática distante das necessidades e possibilidades das escolas públicas em geral.

Isso não invalida esses momentos iniciais que fortalecem mais o preparo do ensino. Porém acreditamos que o processo de planejamento deva decorrer durante os 200 dias letivos do ano, onde os educadores planejam, desenvolvem, avaliam e, principalmente, reinventam o processo escolar de ensinar e aprender.

Aproveitando seu contato direto com professores nesses momentos de planejamento, Fusari (1990) destaca algumas falas sobre a insatisfação desses professores em relação ao seu trabalho: "Eu acho importante planejamento, mas não da forma como vem sendo realizado"; "Do jeito que as coisas estão, impossível planejar o meu trabalho docente, vivo de constantes improvisações"; "Eu sempre transcrevo o planejamento do ano anterior, acrescento algo quando dá, entrego e pronto. Cumpri a minha obrigação".

Esse desconforto dos professores é refletido em sua prática quando preenchem formulários já pré-estabelecidos pela coordenação, com objetivos, conteúdos, 
estratégias, avaliação, indicação de livros didáticos, etc., feitos quase que mecanicamente, cumprindo prazos e rituais formais, vazios de sentido. Ou quando não fazem fotocópias do plano do ano anterior, como dito acima, o que é, infelizmente, uma prática muito comum nas escolas.

Não podemos desconsiderar que a grande maioria dos professores recebeu uma educação formal fundamentada na transmissão cultural, e não teve oportunidade de discutir e fazer um plano de curso (de Química, no nosso contexto) em sua formação inicial. Conseqüentemente, os professores ainda não estão conseguindo conceber coletivamente um planejamento com caráter processual, aberto e flexível, pois isso requer uma mudança radical em suas concepções e prática docente (MALDANER, 2000).

Além disso, o número elevado de estudantes em cada classe e a heterogeneidade de suas capacidades e suas formações tem sido um complicador não indiferente do comportamento do professor e de seu processo de escolha e organização das atividades didáticas (VILLANI e PACCA, 1997).

Por tudo isso, o ensino de Química atual, não tem atendido de forma adequada às necessidades de um curso voltado à formação da cidadania, conforme dispõe a legislação de ensino. O professor fica dividido entre as propostas inovadoras racionalmente aceitas, e as concepções, interiorizadas de forma espontânea a partir da vivência irrefletida. Daí, a distância entre o planejamento de curso e a ação em sala de aula, entre as idéias defendidas e a prática realizada (GARRIDO e CARVALHO, 1999).

Nosso objetivo, ao trabalhar com planejamento escolar, é primeiramente analisar qual a concepção que o professor de Química do Ensino Médio tem sobre planejamento e como ele elabora seu plano de ensino em seu cotidiano escolar a partir da seguinte pergunta:

a) Qual é a concepção desses professores de Química do Ensino Médio sobre planejamento escolar e como eles elaboram seu plano de curso para sua prática docente?

Em seguida queremos identificar possíveis mudanças nesse plano, após um ano de participação dos professores no Projeto Laboratório Didático Virtual - LabVirt, oferecido pela Escola do Futuro da Universidade de São Paulo aos professores da Rede Estadual de Ensino de São Paulo, onde uma de suas tarefas era a elaboração de um plano de aula utilizando a metodologia proposta pelo LabVirt. Para isso, propomos mais uma questão a investigar: 
b) O projeto LabVirt, como um programa de formação contínua, possibilitará que os professores percebam o plano de ensino não apenas como um rol de conteúdos mas também como um documento imprescindível para sua prática docente, explicitando os objetivos, os procedimentos de ensino, os recursos e a avaliação do processo de ensino-aprendizagem de forma integrada, detalhada, refletindo a realidade da sala de aula?

No primeiro capítulo discutimos sobre a Formação Continua de Professores e mais especificamente os de Química, onde apontamos propostas para uma formação mais efetiva. No segundo capítulo, fazemos considerações teóricas sobre o planejamento, sua importância para a prática docente e quais as necessidades do professor para elaboração de seu plano de ensino. No capítulo 3 abordamos a metodologia da pesquisa incluindo o seu contexto, como se deu a intervenção com os professores, como se procedeu a coleta de dados e quais são os nossos referencias teóricos para a análise desses dados.

A exposição e análise dos dados estão no capítulo seguinte, onde descrevemos as discussões sobre planejamento que aconteceram no encontro com todos os professores participantes do projeto e organizamos os dados de cada professor pesquisado, individualmente. A partir da análise desses dados buscamos responder nossa primeira questão de investigação.

Completando nossa análise, no capítulo 5, fazemos uma comparação entre os professores com o intuito de responder a segunda questão da pesquisa e extrapolamos os dados para a realidade de nossas escolas apontada na literatura.

Para finalizar, nas considerações finais indicamos as implicações que esta pesquisa gera para a área de formação contínua de professores. 


\title{
1. FORMAÇÃO CONTÍNUA DE PROFESSORES DE QUÍMICA
}

\author{
Não há política ou programa de formação \\ contínua que consiga aperfeiçoar um professor que \\ não queira crescer, que não perceba o valor do \\ processo individual-coletivo de aperfeiçoamento \\ pessoal-profissional.
}

José Cerchi Fusari

As reformas educacionais, implantadas nos últimos dez anos, representam um período de grandes mudanças para a educação brasileira e conseqüentemente para os professores. Novos conteúdos, novas metodologias de ensino, conceito de avaliação, entre outros, baseando-se em pressupostos construtivistas ${ }^{5}$, foram propostos pela legislação vigente (LDB, PCN) exigindo do professor o desenvolvimento de suas competências profissionais.

Considerando que somente a formação inicial não daria conta de desenvolver nos professores tais competências, a formação contínua vem se institucionalizando como forma de atender às demandas da educação. As secretarias de Educação, por exemplo, têm firmado convênios com universidades públicas e privadas para realizar programas de formação contínua - Teia do Saber ${ }^{6}$ - na forma de cursos, conferências, seminários, com o propósito de enfrentar a baixa qualidade do ensino da escola pública, onde poderão suprir as deficiências de sua formação inicial e entrarão em contato com novas tecnologias, metodologias e técnicas de ensino-aprendizagem (SOUZA, 2002).

${ }^{5}$ Construtivismo: Concepção teórica que parte do princípio de que o conhecimento é determinado pelas interações entre sujeito e objeto. A idéia é que a criança não nasce inteligente, mas também não é passiva sob a influência do meio. Ao contrário, responde aos estímulos externos agindo sobre eles, transformando-os e assimilando-os a suas estruturas mentais (COLL, PALACIOS E MARCHESI, 1996).

${ }^{6}$ Teia do Saber: Programa de Formação Continuada da Secretaria da Educação do Estado de São Paulo que tem como finalidade a atualização permanente para o uso de novas metodologias voltadas para práticas inovadoras e para o uso de materiais didáticos que atendam às necessidades de aprendizagem das crianças e jovens, explicitadas pelos indicadores de desempenho; desenvolvimento de competências para a utilização de novas tecnologias a serviço da aprendizagem; adoção de práticas de avaliação como instrumento de acompanhamento do trabalho docente e do percurso do aluno, seus avanços e dificuldades, como propósito de redimensionar as ações (CENP, 2005). 
Nesse contexto, a formação de professores de Ciências vem sendo pensada e estruturada por Instituições Superiores, na figura de grupos de pesquisa em Ensino de Química, para que os professores adquiram os instrumentos necessários para assumir os desafios que se interpõem em suas práticas (LIMA, 1996). Consideram-se novas estratégias para a formação de profissionais da educação de forma a incorporar as mudanças dos sistemas produtivo e educacional que exigem dos professores a capacidade de identificar as necessidades e desafios da sociedade, impondo assim uma dinâmica de permanente reconstrução de conhecimento, saberes, valores e atitudes.

[...] O recente crescimento de uma visão construtivista de ensino e aprendizagem nos meios didáticos recoloca o problema da formação do professor, ressaltando a importância do seu conhecimento científico e da natureza de sua competência profissional (VILLANI e PACCA, 1997).

Porém, devemos pensar que o educador é antes de tudo um ser humano produto de múltiplas e contraditórias determinações. Para Beattie (1995), tornar-se e ser um professor está cada vez mais sendo reconhecido como um processo complexo, que envolve a pessoa intelectualmente, moralmente, emocionalmente e esteticamente. Isso influencia diretamente na construção da cultura docente que, em interação com as exigências da realidade moderna, configura a conduta acadêmica e profissional desse professor que em muitos casos apresenta-se complexa, instável, incerta e conflitiva.

De modo geral espera-se do professor de Ciências não só uma sólida formação científica como também pedagógica, bem como a capacidade de utilizar diversas estratégias didáticas a fim de que seus alunos alcancem uma adequada alfabetização científica ao final da educação básica.

Para Strike e Posner citados em Villani e Pacca (1997), o professor tem a tarefa principal de monitorar o crescimento cognitivo e o amadurecimento pessoal dos estudantes, contribuindo para a construção, por parte de cada um, de um conhecimento pessoal, com a dupla característica de ser semelhante ao conhecimento científico estabelecido e ter continuidade com a própria ecologia conceitual [...].

Muitas são as necessidades formativas do professor de Ciências apontadas pela literatura (GIL-PÉREZ e CARVALHO,1998; BALWIK, 2000; FURIÓ e CARNICER, 2002). Segundo esses autores, espera-se que o docente seja capaz de:

- romper com visões simplistas de ensino-aprendizagem;

- conhecer a matéria a ser ensinada tendo a convicção da sua importância e seu valor para os alunos e a sociedade em geral; 
- questionar as idéias docentes de "senso comum", desenvolvendo o hábito da reflexão consciente e crítica;

- adquirir conhecimentos teóricos sobre a aprendizagem das ciências;

- analisar criticamente o "ensino tradicional";

- preparar atividades capazes de gerar uma aprendizagem efetiva, propondo situações-problema relacionadas tanto com os conteúdos fundamentais como com os de interesse do aluno e da sociedade;

- conduzir o trabalho dos alunos;

- desenvolver e aplicar diferentes instrumentos para avaliar o processo de ensino-aprendizagem;

- auto avaliar-se;

- adquirir a formação necessária para associar ensino e pesquisa didática;

- trabalhar em equipe, entre outras.

Analisando os professores em serviço ou recém-formados, podemos dizer que a grande maioria não possui todas essas habilidades, o que deixa evidente que as instituições formadoras de professores pouco estão colaborando para essa formação, já que colocam no mercado de trabalho, profissionais sem uma perspectiva pedagógica e sem que compreendam seu papel de professor no nível da formação "ambiental", dentro do "senso comum" da profissão docente e da tarefa de ensinar e educar (MALDANER, 2000).

Pensando nessa figura complexa e nos objetivos que se deseja alcançar, a formação contínua precisa ser pensada a fim de promover uma revisão, renovação e aprofundamento de conhecimentos, atitudes e habilidades desse professor em serviço, sem esquecer de considerar o que dele se espera.

E ainda, incluindo os professores recém-formados no processo de formação contínua, é necessário contrapor-se às suas concepções simplistas sobre o processo de ensino, quando pensam que para ensinar basta saber o conteúdo específico da disciplina, o que evidencia o seu "despreparo" para integrar o conhecimento acadêmico de Química ao conhecimento pedagógico. Como conseqüência, apresentam com freqüência a idéia de que cumprir a tarefa de "passar" ou "transmitir" o extenso conteúdo da disciplina, geralmente da maneira que aparecem nos livros didáticos, é fácil e muito rápido.

A prática atual de formação inicial mais freqüente de professores, isto é, a separação da formação profissional específica da 
formação em conteúdos, cria uma sensação de vazio de saber na mente do professor, pois é diferente saber os conteúdos de Química, por exemplo, em um contexto de Química, de sabê-los, em contexto de mediação pedagógica dentro do conhecimento químico (MALDANER, 2000).

Porém, estamos cientes de que somente a formação inicial de professores não daria conta de preparar os professores para cumprir com excelência todas as habilidades e competências apresentadas acima, principalmente se considerarmos que a formação não se esgota na formação inicial, devendo prosseguir ao longo da carreira, de forma coerente e integrada, respondendo às necessidades de formação sentidas pelo próprio e às do sistema educativo, resultantes das mudanças sociais e/ou do próprio sistema de ensino (RODRIGUES E ESTEVES, 1993).

Assim, podemos pressupor que a graduação não basta para o professor, pois este, em sua prática pedagógica, depara-se com inúmeras situações de natureza diferente daquelas encontradas em sua formação inicial, dada a riqueza e complexidade do dia-a-dia do ato pedagógico.

Há a necessidade de um contínuo aprimoramento profissional do professor, com reflexões críticas sobre sua prática pedagógica, no ambiente de seu contexto de trabalho, porque o assumo como profissional e, portanto, submetido às condições sociais de produção do seu trabalho docente (SCHNETZLER, 2002).

Nessa perspectiva, as propostas de ações e programas de formação contínua vêm tomando espaço na medida em que alguns profissionais acreditam na melhoria das escolas em nosso País e, portanto, na educação como direito do cidadão e dever do Estado.

Villani e Pacca (1992) concebem como formação contínua uma atualização que se faz necessária em função do progresso crescente, tanto do campo científico e tecnológico como do campo epistemológico e pedagógico, que deve ter como estratégia um programa capaz de levar a uma mudança conceitual do que seja ensinar para que o professor possa produzir um programa de ensino de qualidade.

Rodrigues e Esteves (1993), por sua vez, entendem a formação contínua como aquela que tem lugar ao longo da carreira profissional após a certificação profissional inicial e que consiste num processo de aprendizagem e de socialização, de natureza 
voluntária, informal e pouco previsível, centrada na interação entre colegas e nos problemas que trazem de suas práticas docentes.

Caldeira, citado em Cunha e Krasilchick (2000), considera a formação contínua de professores como um processo, que como tal não se esgota também em cursos de atualização, mesmo considerando-se situações em que esses aconteçam na escola em que o professor trabalha, local privilegiado de reflexão pedagógica.

A partir das definições propostas por alguns autores, Garcia (1994) discute a formação contínua procurando expressar diferentes aspectos sobre o mesmo tema (aperfeiçoamento, formação em serviço, formação continuada, reciclagem, desenvolvimento profissional ou desenvolvimento dos professores) e conclui que o desenvolvimento profissional de professores deve contemplar os seguintes aspectos:

Desenvolvimento pedagógico - melhora do ensino do professor mediante atividades centradas em determinadas áreas do currículo, em estratégias instrucionais ou em gestão de classe;

Conhecimento e compreensão de si mesmo - orientado a alcançar do professor uma imagem de si mesmo equilibrada e auto-atualizada;

Desenvolvimento cognitivo - aquisição de conhecimentos e melhora das estratégias de processamento de informações por parte dos professores;

Desenvolvimento teórico - baseada na reflexão do professor sobre sua prática docente;

Desenvolvimento profissional - através da investigação;

Desenvolvimento da carreira - mediante a adoção de novas relações docentes.

Porém, enquanto não se atinge esse nível de desenvolvimento profissional, muitos são os problemas vivenciados pela maioria dos professores, chegando a ser um consenso entre os que lecionam Química que, para melhorar a aprendizagem de seus alunos, seria necessário: fazer com que estes se interessarem pela Química, tornando seu ensino mais significativo; ter mais clareza sobre o que precisa ser ensinado de Química na escola fundamental e média; ter maior fundamentação em Química e em Educação, de maneira a lhes permitir a construção de seus próprios programas, já que reconhecem que o programa tradicional de Química contemplado nos livros didáticos, muitas vezes o único recurso didático - tem pouca serventia para seus alunos; conhecer e discutir possibilidades de como alcançar tais propósitos pedagógicos; tornarem-se melhores professores (SCHNETZLER, 2002). 
Então, na busca de superar tantos problemas, alguns professores comprometemse com sua auto-aprendizagem através da literatura, documentos oficiais, revistas da área ou buscam grupos de estudos, denominados de formação contínua, a fim de conhecerem os "instrumentos" necessários para assumirem os desafios que se interpõem em suas práticas e recuperarem, mesmo que parcialmente, resultados fundamentais não conseguidos com a formação inicial.

Para Maldaner (2000), os processos de formação contínua já testados e que podem dar respostas positivas a essas exigências têm algumas características relevantes:

- grupos de professores que decidem pensar e organizar seu tipo de aula e o conteúdo que irão ensinar, tendo a orientação maior - por exemplo, os Parâmetros Curriculares - como referência e não como fim;

- a prevalência dos coletivos organizados sobre indivíduos isolados, como forma de ação;

- a interação entre professores universitários, envolvidos e comprometidos com a formação de novos professores;

- o compromisso das escolas com a formação contínua de seus professores e com a formação de novos professores compartilhando seus espaços e conquistas;

- o apoio institucional e de autoridades educacionais locais às ações planejadas e executadas conjuntamente;

- o apoio financeiro para a melhoria das condições materiais das escolas e de estudo dos professores;

- as ações coletivas no âmbito de todas as licenciaturas de uma instituição.

Mas será que, com isso contemplado, seria prudente pensar que tendo professores mais capacitados e comprometidos com os valores que eles representam, conseqüentemente teríamos escolas mais participativas, inovadoras e abertas a adaptações curriculares?

Acreditamos que não, pois, da mesma forma que somente a formação inicial não oferece condições para o total desenvolvimento desse profissional, comprometendo sua atuação em sala de aula, a formação contínua não pode ser apresentada como a salvação para todos os problemas da escola se considerarmos que a formação de professores faz parte de uma rede de interação entre a sociedade e o sistema educacional (SOUZA, 2002) e, então, está sujeita muitas vezes a interesses políticos e não educacionais, gerando dúvidas sobre a eficiência desses programas. 
Algumas pesquisas sugerem justificativas para a falta de eficiência desses programas, apesar de haver um consenso sobre a importância e a necessidade da formação contínua de professores. Garrido e Carvalho, citados por Cunha e Krasilchik (2000), apontam para a não integração entre a Universidade e as escolas de Ensino Médio e entre estudos teóricos e a prática docente. Villani e Freitas (2002) seguem a mesma perspectiva ao verificarem que a construção dos conhecimentos que orientam os projetos de inovação contínua ocorre fora do contexto escolar, sendo iludidos pelos movimentos de inovação no ensino mantendo os moldes da racionalidade técnica. Assim, há um descompasso entre o "especialista" e os professores, no que se refere ao que é "apresentado" pelo primeiro, por meio de suas propostas inovadoras, e o que é, de fato, "desejado" pelos professores.

Schnetzler (2002) aponta, além da falta de relação entre o que é tratado ou ensinado nos cursos de formação contínua e os problemas vivenciados pelos professores, a falta de continuidade destes cursos não permitindo que o professor possa discutir seus dilemas, hesitações e inseguranças com seus pares ou mesmo com o orientador do curso, a realização destes cursos fora do contexto de produção do trabalho docente e, por fim, a usual obrigatoriedade dos professores nessas ações.

Esta autora ainda enfatiza que mudanças na prática pedagógica não acontecem por imposição ou apenas porque se deseja. Mudanças e inovações em nossas práticas de ensino requerem de nós explicitar, desconstruir e reconstruir concepções e isto demanda tempo e condições que não podem ser contempladas por ações de formação continuada tão curtas, esporádicas e descontínuas.

Finalmente podemos concluir que a formação contínua tende a ter mais sucesso quando:

- ocorre predominantemente na escola - formação contínua em serviço;

- existe uma equipe de lideranças (diretor, vice-diretor, coordenador pedagógico) e esta valoriza e viabiliza o processo de construção permanente do Projeto Político Pedagógico $^{7}$ (PPP) da Unidade Escolar;

${ }^{7}$ Projeto Político Pedagógico: é o plano global da instituição. Pode ser entendido como a sistematização, nunca definitiva, de um processo de Planejamento Participativo, que se aperfeiçoa e se concretiza na caminhada, que define claramente o tipo de ação educativa que se quer realizar. É um instrumento teórico-metodológico para a intervenção e mudança da realidade. É um elemento de organização e integração da atividade prática da instituição neste processo de transformação (Vasconcellos, 2002). 
- há o movimento permanente de construir, desconstruir e reconstruir o PPP que funciona como "mola propulsora" da formação contínua do coletivo de educadores;

- o trabalho pedagógico em curso (planejamento e ação em sala de aula) transforma-se em objeto de estudo e questionamentos dos educadores;

- os educadores apresentam disponibilidade para vivenciar este processo, entendendo-o como parte integrante do seu desenvolvimento pessoal e profissional;

- transforma-se em um valor cultural para educadores, educandos e a comunidade escolar ampliada. 


\section{CONSIDERAÇÕES TEÓRICAS SOBRE O PLANEJAMENTO DE ENSINO E SUA IMPORTÂNCIA}

...é impossível enumerar todos os tipos e níveis de planejamentos necessários à atividade humana. Sobretudo porque, sendo a pessoa humana condenada por sua racionalidade, a realizar algum tipo de planejamento, está sempre ensaiando processos de transformar suas idéias em realidade.

Danilo Gandin (2001)

Faz parte do cotidiano do ser humano organizar suas ações para alcançar seus desejos. Para essa organização a pessoa pensa, prevê, imagina, sonha e toma decisões a todo o momento a fim de alcançar seus objetivos da melhor maneira possível. Estamos sempre pensando: vou fazer isso ou aquilo; faço desta forma ou de outra; posso fazer com isso ou com aquilo. A pessoa quando pensa sobre as suas ações diárias está planejando o seu "quê fazer". Ou seja, de uma forma ou de outra, de uma maneira empírica ou científica, o homem planeja (MENEGOLLA e SANT'ANNA, 2003).

A atividade/atitude de planejamento é inerente ao processo de ensinar e aprender. Isso significa que a escola sempre planejou seu trabalho, tomando como referência as diretrizes advindas de órgãos centrais como o MEC e as Secretarias de Educação. Historicamente, o espaço de autonomia da escola para planejar o seu trabalho era sempre delimitado, mais voltado à execução do que à concepção. Somente a partir da promulgação da LDB 9394/96 a autonomia da escola ganhou mais força na direção do espaço-sujeito do trabalho educativo e passou então a assumir a responsabilidade de, a partir do currículo já existente, elaborar coletivamente seu PPP e seus planos de ensino e curso a partir do planejamento (APEOESP, 2005).

Há uma confusão no ambiente escolar quanto à compreensão do conceito de planejamento e o uso adequado do mesmo, o que entendemos ser um complicador para o exercício da prática de planejar dos professores. Os educadores em geral utilizam em seu cotidiano o termo planejamento de ensino como sinônimo de plano de ensino, e estes possuem conceitos bem diferentes como veremos a seguir. 


\subsection{Planejamento}

Podemos partir de uma concepção de dicionário para definir planejamento:

planejamento. S. m. 1. Ato ou efeito de planejar. 2. Trabalho de preparação para qualquer empreendimento, segundo roteiro e métodos determinados; planificação. 3. Bras. Elaboração, por etapas, com bases técnicas (especialmente no campo sócio-econômico), de planos e programas com objetivos definidos; planificação (FERREIRA, 1988).

Porém numa revisão bibliográfica sobre o conceito dado ao planejamento de ensino percebemos que a definição acima é um pouco restrita já que não articula a elaboração e a realização de uma ação. Sendo assim destacamos a seguir algumas definições de vários autores:

- [...] é o processo que envolve "a atuação concreta dos educadores no cotidiano do seu trabalho pedagógico, envolvendo todas as suas ações e situações, o tempo todo, envolvendo a permanente interação entre os educadores e entre os próprios educandos" (FUSARI, 1988).

- [...] é o instrumento pedagógico imprescindível na atuação profissional, que, tendo objetivos bem definidos, guarda particularidades e especificidades de acordo com os usuários e as condições da sua utilização (PACCA, 1992).

- é um processo, não algo estanque, mas uma ação contínua e globalizante (DÁLMAS, 1994).

- é um processo cíclico, contínuo e interativo que ocorre em três fases sobrepostas (pré-atividade, atividade, e pós-atividade). Ele começa com uma idéia geral em forma de problema que é resolvido pela elaboração progressiva de planos (Bellon et al. in SANCHÉZ e VALCÁRCEL, 1999).

- [...] é o processo, contínuo e dinâmico, de reflexão, tomada de decisão, colocação em prática e acompanhamento (VASCONCELLOS, 2002). 
- [...] é um processo global que vai desde a definição de uma filosofia da educação até o estabelecimento dos processos para se desenvolver uma filosofia que oriente todo o processo (MENEGOLLA e SANT'ANNA, 2003).

- [...] organização da ação pedagógica intencional de forma responsável e comprometida com a formação dos alunos. Em uma percepção crítica da educação o processo de planejamento extrapola a simples ação de elaborar um plano de ensino tecnicamente recomendável e passa a demonstrar o cuidado e o compromisso do professor em dar à sua matéria de ensino o direcionamento para o alcance das finalidades da educação, para a concretização do projeto pedagógico da escola e para o desenvolvimento de saberes fundamentais em seus alunos (LOPES, 2004).

- processo de tomada de decisões bem informadas que visam à racionalização das atividades do professor e do aluno, na situação ensino-aprendizagem, possibilitando melhores resultados e, em conseqüência, maior produtividade (TURRA et al., 2004).

A partir dessas definições podemos reconhecer que o planejamento de ensino trata de um processo, e não de um documento real, de racionalização, organização e coordenação da atividade do professor buscando aproximar o máximo a realidade ao ideal. É uma práxis onde se reflete criticamente, questiona e avalia as ações e opções ao alcance do professor procurando atender as necessidades dos educandos.

Sendo assim, consideramos que, se o professor não entender o planejamento como uma necessidade para a prática docente, sua ação em sala de aula estará submetida ao acaso e, conseqüentemente, comprometida no que diz respeito à qualidade.

Portanto, o planejamento deve ser concebido, assumido e vivenciado no cotidiano da prática social docente, como um processo de reflexão articulado sobre os problemas e a realidade da educação escolar no processo ensino-aprendizagem, de forma a identificar a raiz do problema, usando o método científico e considerando uma visão total do fenômeno (FUSARI, 1990).

Considerando que os professores investigados nesta pesquisa são docentes em Escolas Estaduais de São Paulo, buscamos referências sobre o planejamento em documentos elaborados pela Secretaria de Estado da Educação (SEE) juntamente com a Coordenadoria de Estudos e Normas Pedagógicas (CENP) no início de cada ano letivo, que são disponibilizados às Diretorias de Ensino e Unidades Escolares. 
Para o ano letivo de 2005, o documento Planejamento 2005 - Orientações para elaboração do planejamento nas escolas e na Diretoria de Ensino propõe que para o momento do planejamento é importante refletir sobre os registros dos resultados educacionais, avaliando o comprometimento de todos os envolvidos na aprendizagem dos alunos, verificar a qualidade e o alcance das ações pedagógicas desenvolvidas e a satisfação dos alunos, dos pais e outros integrantes da comunidade em relação aos serviços prestados pela escola, para então estabelecer o que está dando certo e deve ser mantido e o que parece necessário mudar e como. A partir desta avaliação da gestão escolar, junto com a proposta pedagógica da escola, é que começa a se pensar nas prioridades estabelecidas, nos objetivos e nas metas pretendidas.

Em 2006, no documento Subsídios para o planejamento escolar/2006, foi proposto que o planejamento deveria dar destaque à garantia da função social da escola, à gestão democrática e à construção participativa da proposta pedagógica. Ao considerarem que o foco do processo de planejamento é a garantia de sucesso do aluno, o documento propõe como sendo necessário para a realização das ações de planejamento:

1) a consciência de que o planejamento é um movimento contínuo que não se esgota no período previsto em calendário escolar, mas antecede e ultrapassa esse limite;

2) que a equipe gestora tenha claro o aspecto processual, flexível e dinâmico do ato de planejar; e

3) que, inicialmente, dê respostas a duas questões norteadoras desse processo:

- Quais as etapas necessárias à construção do planejamento escolar?

- Que questões devem nortear as discussões, reflexões e ações desenvolvidas em cada etapa desse processo?

Sendo esses documentos oficiais da Secretaria de Estado da Educação, entendemos que, ao menos, os professores das Unidades Escolares deveriam ter acesso a essas informações no momento do planejamento e considerar suas orientações para a elaboração de seus planos de ensino.

Outros órgãos também elaboram documentos a fim de subsidiar os professores na sua prática pedagógica. O Sindicato dos Professores do Ensino Oficial do Estado de São Paulo (APEOESP), órgão do qual muitos professores são associados, em seus Cadernos de Formação $(2001 ;$ 2005) destacam o desgaste que o planejamento vem 
sofrendo nestes últimos anos culminando no descrédito e burocratização desta atividade e orientam sobre a concepção de planejamento e como organizá-lo nas escolas.

Para este órgão o planejamento do ano letivo constitui-se num momento privilegiado para reflexão coletiva sobre as ações educacionais e de integração da equipe de trabalho. É quando podemos analisar o que desenvolvemos até a presente data e então, traçar metas para a atuação da escola e para cada um de nós, quanto à formação dos nossos alunos, e a transformação da realidade escolar. O planejamento embasa a elaboração, o desenvolvimento e a avaliação de planos de ensino e o preparo de aulas. Traduz-se numa atividade e vivência crítica permanente diante do trabalho pedagógico, possibilitando ao conjunto da equipe de profissionais da escola conhecer, se apropriar e participar da construção do projeto educacional em desenvolvimento (APEOESP, 2005).

Pensando na concretização deste processo com a eficiência que lhe é necessária é preciso diagnosticar as necessidades de todos os envolvidos; planejar, com os pés na realidade, os conteúdos, suas abordagens e articulações, bem como sua avaliação; discutir as condições que precisam se fazer presentes na escola para que se realize um trabalho educativo digno e com qualidade; assegurar espaço para a efetiva presença e participação dos alunos, pais e comunidade nos rumos do trabalho escolar; reivindicar firmemente, junto aos órgãos responsáveis, as condições ausentes (APEOESP, 2001).

Assim percebemos que planejar não é uma tarefa tão simples, mecânica e burocrática como tem acontecido em grande parte das escolas. Isso requer um maior envolvimento e dedicação de todas as pessoas que deveriam fazer parte do processo: diretor, coordenador, professor, aluno e sociedade.

Então, para envolver toda a comunidade escolar nas ações do planejamento, a Secretaria de Estado da Educação (SÃO PAULO, 2006) sugere:

1. Sensibilizar e mobilizar diferentes sujeitos que constituem a comunidade escolar e definir critérios, espaços e limites de participação de cada um (professores, pessoal técnico-pedagógico e técnico administrativo, alunos, pais e parceiros), observadas as disposições contidas na Constituição Federal/88, na LDB e nas Normas Regimentais Básicas.

2. Estudar, discutir e compreender a função social da escola, a concepção de aprendizagem e de currículo presente nos documentos que referendam as políticas públicas de educação (LDB, Diretrizes e nos Parâmetros Curriculares Nacionais, Propostas Curriculares da CENP, Proposta Pedagógica da Escola e no Regimento Escolar, entre outros). 
3. Garantir acesso à documentação e registros, organizando tempo para estudo e discussão e prover espaço para os encontros.

4. Utilizar os indicadores de avaliação disponibilizados pelo MEC e pela Secretaria de Estado da Educação, e os organizados pela escola.

5. Buscar o envolvimento do profissional da educação e disponibilizar tempo e espaços, não só para a construção do projeto escolar, mas para a sua permanente execução, que envolve planejamento constante, de caráter interdisciplinar, crítico e que conduz ao sucesso do aluno.

Ao pensarmos especificamente no professor de Ciências, seus planos de ensino estão condicionados às referências educacionais adquiridas em sua formação científica e didática, além de suas concepções pessoais de educação adquiridas ao longo da sua prática docente. Isto é ressaltado por Sánchez e Valcárcel (1993), ao relacionarem o tipo de competências que requer um professor de Ciências e as ações necessárias para planejar seu ensino. (Figura 1) 


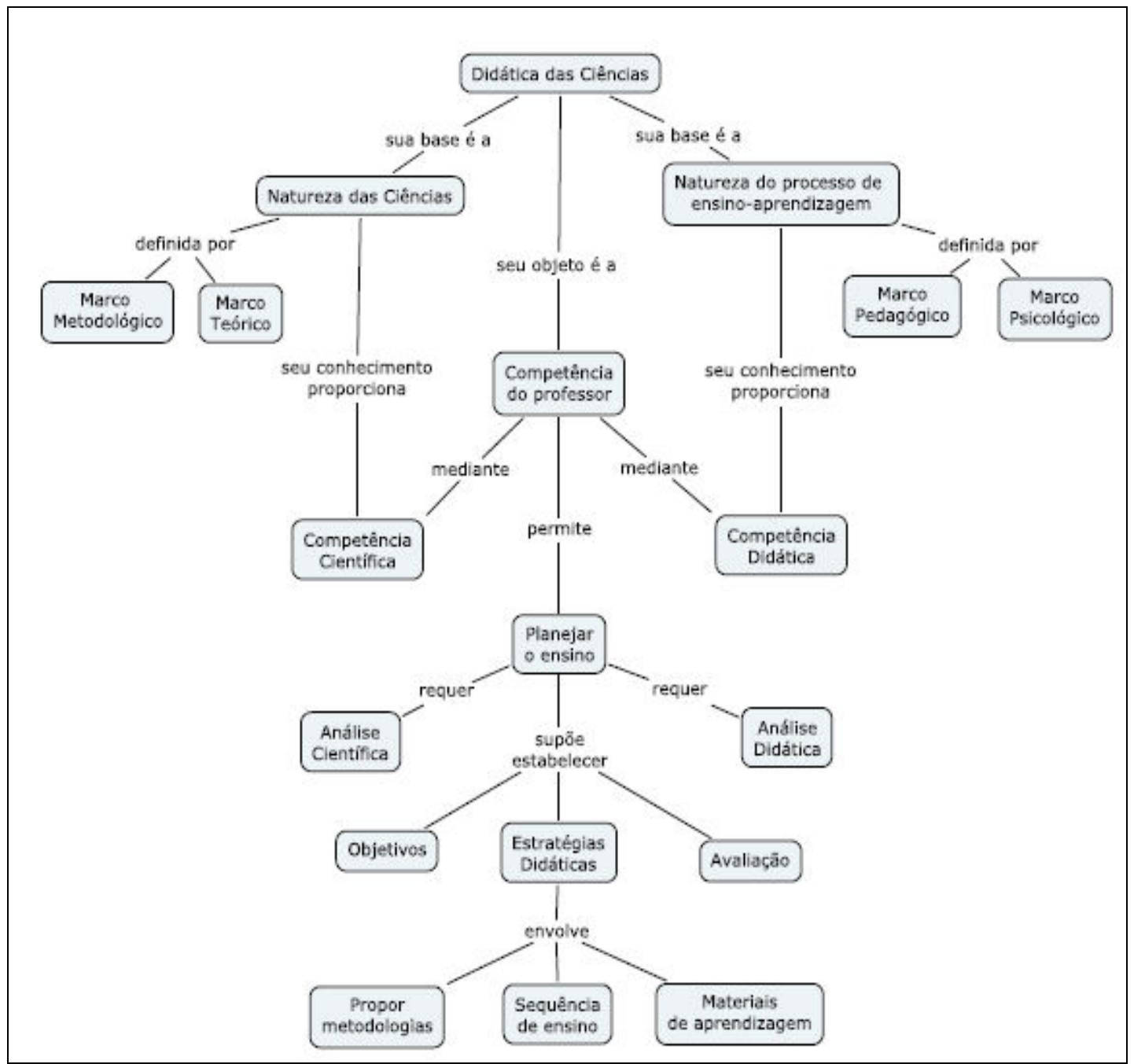

Figura 1. Didática das Ciências (SÁNCHEZ e VALCÁRCEL, 1993)

Assim, a partir das diversas propostas e necessidades relacionadas ao planejamento sentimos que o ideal seria um planejamento que envolvesse as pessoas como sujeitos de um processo, desde sua elaboração, com presença constante na execução até sua avaliação, na medida que entendemos o planejamento como sendo o caminho para combatermos as atividades desarticuladas e casuístas, e fundamental para buscar a construção de práticas educativas sintonizadas com as atuais necessidades dos nossos alunos e da sociedade.

\subsection{Plano de curso ou plano de ensino}

Partindo da idéia de que planejamento de ensino é algo mais amplo e abrange a elaboração, execução e avaliação de planos de ensino, entendemos que o plano de ensino é um dos resultados do processo do planejamento. Plano de ensino é, pois, um 
documento elaborado pelo(s) docente(s), contendo a(s) sua(s) proposta(s) de trabalho, numa área e/ou disciplina específica (FUSARI, 1990).

Segundo Vasconcellos (2002), o plano é o produto do planejamento, de um processo, contínuo e dinâmico, de reflexão, tomada de decisão, colocação em prática e acompanhamento, que pode ser explicitado em forma de registro, de documento ou não.

O professor que deseja realizar uma boa atuação docente sabe que deve participar, elaborar e organizar planos em diferentes níveis de complexidade para atender, em classe, seus alunos. Pelo envolvimento no processo ensino-aprendizagem, ele deve estimular a participação do aluno, a fim de que este possa, realmente, efetuar uma aprendizagem tão significativa quanto o permitam suas possibilidades e necessidades (TURRA et al., 2004).

A fim de destacar a importância do plano de disciplina para o professor, já que entendemos ser este um instrumento fundamental para sistematizar sua práxis e buscar atingir os objetivos da sua disciplina, selecionamos o que Menegolla e Sant'Anna (2003) apontam como justificativa para o professor planejar:

- ajuda o professor a definir os objetivos que atendam os reais interesses dos alunos;

- possibilita ao professor selecionar e organizar os conteúdos mais significativos para seus alunos;

- facilita a organização dos conteúdos de forma coerente, obedecendo a estrutura da disciplina;

- ajuda o professor a selecionar os melhores procedimentos e os recursos, para desencadear um ensaio mais eficiente, orientando o professor no como e com que deve agir;

- ajuda o professor a agir com maior segurança na sala de aula;

- o professor evita a improvisação, a repetição e a rotina no ensino, sendo necessário acompanhar as novidades da sala de aula;

- facilita uma melhor integração com as mais diversas experiências de aprendizagem;

- facilita a integração e a continuidade do ensino;

- ajuda a ter uma visão global de toda a ação docente e discente; 
- ajuda o professor e os alunos a tomarem decisões de forma cooperativa e participativa.

Com isso, percebemos que só fará um plano de ensino aquele professor que está comprometido com a educação de seus alunos e que, então, deseja direcionar sua matéria de ensino para o alcance das finalidades da educação, para a concretização do projeto pedagógico da escola e para o desenvolvimento de saberes fundamentais em seus alunos.

Para sistematização do seu plano de ensino, dentre outras estruturas (VASCONCELLOS, 2002; TURRA et al., 2004; ZABALLA, 1998), Menegolla e Sant'Anna (2003) sugerem que, para o professor planejar uma disciplina, são necessários:

- Conhecimento e análise da realidade do aluno, do professor, da escola e da comunidade;

- Definição dos objetivos dos alunos e dos professores em relação à disciplina;

- Delimitação dos conteúdos mais significativos para atingir os objetivos;

- Escolha dos melhores procedimentos e técnicas de ensino;

- Seleção dos possíveis e melhores materiais de aprendizagem;

- Estabelecimento dos melhores processos de avaliação, assim como as melhores técnicas e instrumentos.

Porém uma simples formalização do procedimento acima, elaborando um plano com objetivos, conteúdo programático, os métodos de ensino, os recursos didáticos, a avaliação da aprendizagem e às vezes a bibliografia a ser consultada, não pressupõe uma eficiência no ensino-aprendizagem da Química. É só pensarmos que todos os professores elaboram seus planos de ensino no início do ano letivo e que o ensino de Química ainda caminha a passos lentos para atingir os objetivos propostos nas Diretrizes Curriculares.

O padrão de plano de aulas adotado pela maioria dos professores nos remete a uma visão tecnicista de educação, e não é suficiente para dinamizar e facilitar o trabalho docente. Além disso, um bom plano não transforma, em si, a realidade da sala de aula, pois ele depende da competência e do compromisso docente (FUSARI, 1990).

Santos e Schnetzler (1996) apontam ser imprescindível o comprometimento do professor, no sentido de recuperar a verdadeira função da educação, buscando, por meio de uma nova postura frente ao aluno, contribuir de fato para a construção de uma 
sociedade democrática, cujos membros sejam cidadãos conscientes e comprometidos com a própria transformação dessa sociedade.

Para se elaborar um plano adequado, Sánchez e Valcárcel (2000) sugerem para o professor determinadas competências pedagógicas como:

- Conhecer em profundidade a disciplina, ou seja, seus objetivos, problemas, leis e teorias, sua história, a prática de sua metodologia cientifica, sua epistemologia e suas interações ciência-tecnologiasociedade associadas à sua construção.

- Adquirir conhecimentos fundamentados sobre a aprendizagem das Ciências; saber detectar, analisar e interpretar as concepções dos alunos para orientar sua aprendizagem, com especial atenção à análise dos possíveis obstáculos que impedem a construção das idéias científicas e ao estabelecimento dos possíveis caminhos para superá-los. Conhecer a psicologia e a sociologia do adolescente para compreender e favorecer sua aprendizagem.

- a) ter critérios para seleção e seqüência do conteúdo de ensino; b) saber formular, em relação com os objetivos e conteúdos de ensino, uma série de metaconhecimentos, um conjunto de procedimentos gerais e uma série de valores básicos que sirvam de referência contínua para o processo de ensino-aprendizagem; c) e concluindo, elaborar redes de conteúdos que relacionem a informação procedente das disciplinas científicas e problemas relevantes e interessantes para os alunos.

Complementando as competências acima citadas, como conhecimentos necessários para os professores a fim de elaborar um plano efetivo e utilizá-lo efetivamente em sua prática, a SEE (SÃO PAULO, 2006) propõe:

1. Compreensão dos conceitos de aprendizagem, competências, interdisciplinaridade e contextualização que são conceitos já interiorizados pelo professor e usado cotidianamente sem que este tenha claro o que cada um significa para a educação, impossibilitando que seu trabalho seja baseado nestes conceitos.

2. Compreensão do significado da organização curricular por competências e áreas do conhecimento. 
3. Consciência sobre a função social da escola, a importância do protagonismo juvenil e das representações que permeiam as relações no âmbito da escola.

4. Entendimento sobre as formas e critérios de Avaliação da Aprendizagem e seu papel na garantia do sucesso do aluno.

Sendo assim, para a elaboração deste plano, o professor não pode pensar em seus objetivos de ensino e suas ações de forma aleatória e pessoal. Um plano para ser útil e significativo, antes de tudo, deve ser constituído de uma seriedade pedagógica, que atenda as reais urgências e necessidades dos alunos (MENEGOLLA e SANT'ANNA, 2003).

Deve-se considerar que os objetivos de ensinar Química e mais amplamente Ciências determinarão toda a estrutura do plano. Todas as decisões a serem tomadas nos diversos momentos do planejamento devem se fundamentar nestes objetivos.

Para isso, a SEE (SÃO PAULO, 2006), nas orientações para a elaboração do plano de curso, propõe que esses objetivos estejam coerentes com as diretrizes curriculares nacionais e estaduais da escola básica, contribuindo efetivamente para a formação de valores essenciais ao convívio social e solidário, proporcionando oportunidades para o desenvolvimento da competência de leitura e escrita e para a inclusão no mundo da cultura, ciência, arte e trabalho.

Essa forma de pensar sobre os objetivos educacionais se justifica a partir dos Parâmetros Curriculares Nacionais, quando os objetivos da educação científica tomaram novos rumos. Propôs-se ensinar Ciências a partir do ensino sobre Ciência. O conceito de conteúdo escolar passou a incluir, além da dimensão conceitual, as dimensões procedimentais e atitudinais. O ensino deve então conjugar harmoniosamente a dimensão conceitual da aprendizagem disciplinar com a dimensão formativa e cultural (CARVALHO, 2004).

A seleção de conteúdos e sua seqüência de ensino têm também sua importância no momento do planejamento, porém não podemos considerar que o plano seja elaborado a partir deles.

Concordamos com Sánchez e Valcárcel (2000), quando dizem que essa tarefa deve ser guiada através de alguns fundamentos e procedimentos para a análise do conteúdo disciplinar e das dificuldades de sua aprendizagem em função das características dos alunos, o que constitui duas tarefas interdependentes, como reflexão prévia para a tomada de decisões em torno da concretização não somente dos objetivos e conteúdos, mas também das estratégias didáticas e da avaliação. 
Alguns estudos têm mostrado que, para o processo de planejamento, os professores detém uma maior atenção na escolha do conteúdo conceitual (SÁNCHEZ e VALCÁRCEL, 1999; SÁNCHEZ e VALCÁRCEL, 2000), como se abrangendo um maior número de temas o ensino será de melhor qualidade. Essa escolha de conteúdo, para uma grande maioria, é baseada em livros didáticos, que no caso dos de Química, aborda os conteúdos de maneira isolada, sem que os assuntos se relacionem, nem entre si nem com a realidade do aluno e baseiam-se na divisão clássica: Química geral para a $1^{\text {a }}$. série do Ensino Médio, Físico-química para a 2a . e Química orgânica para a $3^{\mathrm{a}}$.

Com o Programa Nacional do Livro para o Ensino Médio (PNLEM) ${ }^{8}$ nas Escolas Estaduais, os alunos passarão a ter acesso ao livro didático de Química a partir de 2008 , o que nos leva a crer que o vínculo com o livro didático será fortalecido, engessando ainda mais o ensino de Química, caso o professor não o entenda como um dos meios para o processo ensino-aprendizagem.

Fusari (1990) salienta que o livro didático é apenas um dos instrumentos comunicacionais do professor no processo de educação escolar, para qualquer nível de escolaridade. Isto significa que a capacidade do professor deve ser mais abrangente, não se limitando ao mero recorrer ao livro didático.

Esta postura do professor pode ser justificada a partir da sua formação inicial como professor de Ciências que está orientada para a aquisição de conhecimentos científicos e, portanto, acaba sendo sua referência mais imediata. A maioria dos cursos de licenciatura em Química não está estruturada de maneira que as disciplinas de conteúdo específico e as disciplinas pedagógicas se articulem. Os conteúdos específicos da disciplina compõem quase toda a proposta curricular, "restando" para as disciplinas de Didática e Prática de Ensino abordar os conteúdos pedagógicos. Essa estrutura enfatiza a pouca importância dada às disciplinas pedagógicas frente às específicas.

Se considerarmos que o professor sozinho não deve ser o responsável por estabelecer o que será ensinado em cada nível de ensino na sua instituição, este pode basear-se no currículo escolar, que já deve estar previamente estruturado no Projeto Político-Pedagógico da Unidade Escolar, e a partir daí fazer uma análise crítica para sua seleção com vistas à identificação dos conhecimentos que se mostram essenciais e

${ }^{8}$ PNLEM: Implantado em 2004, o Programa Nacional do Livro para o Ensino Médio prevê a distribuição de livros didáticos para os alunos do ensino médio de todo o País. Inicialmente, o programa atendeu, de forma experimental, os alunos da primeira série do ensino médio de escolas públicas das regiões Norte e Nordeste com livros das disciplinas de português e de matemática. Atualmente, estão disponíveis para escolha também livros das disciplinas de Biologia, Química e História (CENP, 2007). 
aqueles que podem ser considerados secundários naquela fase de aprendizado do educando (LOPES, 2004).

Para auxiliar os professores nessa tarefa, alguns autores (MENEGOLLA e SANT'ANNA, 2003; MARTINS, 2004; TURRA et al., 2004) recomendam que se levem em conta os seguintes aspectos:

- a estrutura lógica da matéria;

- as condições psicológicas da aprendizagem;

- as necessidades sócio-econômicas e culturais dos alunos;

- o significado dentro do campo de conhecimentos;

- o nível de interesse que irá despertar nos alunos;

- a adequação ao nível de maturidade e adiantamento dos alunos;

- os mais úteis em relação a resoluções que o aluno tenha que tomar;

- os que podem ser aprendidos dentro das limitações de tempo e recursos disponíveis.

Concluída a seleção, a organização da seqüência didática em que os conteúdos serão estudados também será pensada no momento do planejamento, e para tanto o professor não pode pensar que a seqüência mais adequada é sempre a estabelecida nos livros didáticos. A seqüência mais lógica e coerente relaciona-se com os objetivos da disciplina, com os conhecimentos dos alunos, com a possibilidade de articular-se com outros conteúdos da mesma disciplina e com as diversas disciplinas do currículo.

Definidos os conteúdos e sua seqüência de ensino, passamos à metodologia que o professor irá propor para ensinar esses conteúdos a fim de atingir seus objetivos. Esta metodologia abrange atividades, procedimentos, métodos, técnicas e modalidades de ensino, selecionados com o propósito de facilitar, ou melhor, proporcionar a aprendizagem. Neste momento o professor pode pensar e sentir, então, em como e com o que ensinar.

Para Sánchez e Valcárcel (1999), essa tarefa envolve uma mudança na postura do professor, ou seja, deixar de ser apenas um administrador dos programas fixos que estão incorporados nos livros didáticos e tornar-se autor ativo do seu curso e investigador, adaptando progressivamente e mudando seu modo de ensinar de acordo com o feedback recebido.

Pensamos ser esse um problema a ser enfrentado pelos professores, pois como a educação pode ocorrer durante toda a nossa vida a partir de acontecimentos diários e também por experiências derivadas da educação formal, como escolas ou universidades, os métodos a serem pensados devem ser capazes de permitir que os educandos façam 
conexões entre o que eles estão aprendendo e os acontecimentos dentro e fora da escola.

Então, quando os professores estão tomando decisões sobre suas práticas em sala de aula, eles devem refletir constantemente sobre como construir experiências que desafiarão seus estudantes a moverem-se além de seus entendimentos e concepções atuais para um melhor entendimento do mundo que os cerca (PARKE E COBLE, 1997).

Mas vale ressaltar que a escolha das estratégias e das propostas didáticas que permitam que o aluno construa o seu conhecimento, deve realizar-se mediante 0 levantamento das atividades que o professor é capaz de dominar em classe e que ao mesmo tempo atendem aos interesses dos alunos, pois se o professor tem pouco domínio da atividade ele acaba por não explorar suas potencialidades didáticas, e, se o aluno tem pouco interesse, ele acaba por desperdiçar as mesmas potencialidades (VILLANI, 1991).

Sendo assim, a opção por uma metodologia ou outra de ensino-aprendizagem está baseada nos interesses imediatos dos alunos e é originada a partir de uma análise crítica do contexto social e das características individuais e grupais desses alunos, considerando também os objetivos pretendidos, a natureza da aprendizagem, a natureza do conteúdo, o conhecimento prévio sobre o conteúdo e ainda aspectos estruturais como número de aulas, tempo de cada aula, ambiente das aulas, número de alunos por sala, etc.

Juntamente com a metodologia, está a seleção e organização dos recursos didáticos, aqui entendidos como os meios materiais e humanos que auxiliarão o professor e o aluno no processo ensino-aprendizagem.

Os recursos materiais possuem uma classificação tradicional que distingue os recursos visuais (projeções, cartazes), os recursos auditivos (rádio, gravações) e os recursos audiovisuais (cinema, televisão). Já como recursos humanos, temos o próprio professor, os alunos, o pessoal escolar e a comunidade.

Dispondo disso, o professor ao planejar sua disciplina deve considerar a importância dos recursos e quanto eles podem objetivar o ensino e a aprendizagem, despertar e manter o interesse dos alunos; auxiliar o professor na comunicação dos conteúdos; facilitar a concretização das idéias e fatos; elucidar conceitos; desenvolver a percepção e provocar a ação do aluno (MENEGOLLA e SANT'ANNA, 2003).

A última etapa e talvez a mais divergente do planejamento é quando se pensa em como avaliar todo o processo de ensino-aprendizagem. Este tema é atualmente muito discutido dentro da academia, no intuito de modificar seus objetivos. Pois, de elemento de referência do andamento do processo para a cooperação com o educando no seu desenvolvimento, tornou-se elemento de controle e dominação, já que o professor usa a 
avaliação como instrumento de pressão quando encontra dificuldades de mobilizar os alunos (VASCONCELLOS, 2002).

Partindo do princípio de que aprender significa dominar criticamente os conhecimentos, atitudes e procedimentos sobre determinados assuntos e saber utilizar essas habilidades para os mais diversos objetivos e nas mais variadas situações, avaliar esta aprendizagem é mais do que aferir o índice de respostas corretas dadas pelos alunos em relação a questões previamente definidas pelo professor, é refletir permanentemente sobre as finalidades e os objetivos do que vem sendo trabalhado, experimentado e vivenciado, no cotidiano das aulas, e as formas como cada aluno, cada grupo de alunos e o professor envolvido vêm atuando e contribuindo para a superação dos desafios de aprendizagem de todos (KENSKI, 2004).

Pensando na formalização do documento, é necessário expressar claramente a avaliação que será efetuada através de testes dissertativos, testes objetivos, exercícios individuais ou em grupos, trabalhos de pesquisa entre outros que devem ser bem adequados aos objetivos, aos conteúdos da disciplina e às características dos alunos, atendendo às condições intelectuais, emocionais e às habilidades psicomotoras dos alunos (MENEGOLLA e SANT'ANNA, 2003).

Ao planejar a avaliação, o professor deve considerar os objetivos e as determinações curriculares. Por isso os documentos escolares, neste caso o Projeto Político-Pedagógico, devem definir a avaliação em termos gerais e amplos, permitindo assim que o professor possa ter certa liberdade em relação ao modo como vai avaliar os seus alunos.

Finalmente, podemos concluir que a ausência de um processo de planejamento de ensino na escola está levando a uma improvisação pedagógica que prejudicará a aprendizagem dos alunos e o próprio trabalho escolar.

Mas, não podemos pensar que só o plano de ensino basta para uma prática pedagógica efetiva e programada. Ainda mais se considerarmos que é este plano que o professor deve entregar para o corpo diretivo da escola e que muitos deles não o consultam mais ao longo do ano. Isso reforça a necessidade do professor preparar as suas aulas, já que cada aula é um encontro curricular, no qual, nó a nó, vai-se tecendo a rede do currículo escolar proposto para determinada faixa etária, modalidade ou grau de ensino (FUSARI, 1990).

No plano de aula o professor descreve detalhadamente os objetivos pretendidos para cada aula e quais os meios necessários para seu alcance. Nesse plano, nota-se uma relação mais estreita entre os objetivos, conteúdos, procedimentos recursos e avaliação. 
Vale lembrar que, assim como o plano de curso, o plano de aula não pode ser considerado como algo que se deva cumprir rigorosamente. Aqui entra a capacidade do professor em perceber quando deve se afastar dele diante de possíveis interesses e necessidades dos alunos que não estavam inicialmente previstos. Porém, esse afastamento não pode se transformar numa prática habitual. Isso só mostraria que o plano de aula não está adequado àquela turma, podendo ser reavaliado e, se necessário, replanejado. 


\section{METODOLOGIA DA PESQUISA}

\subsection{O contexto: Projeto Laboratório Didático Virtual Química - LabVirt}

O Projeto Laboratório Didático Virtual Química - LabVirt (www.labvirtq.futuro.usp.br), desenvolvido pela Escola do Futuro da Universidade de São Paulo em parceria com a Faculdade de Educação, Escola Politécnica e Escola de Comunicação e Artes, foi organizado em 2004 como uma expansão do LabVirt Física (1999), e tem como principal objetivo construir uma infra-estrutura pedagógica e tecnológica - comunidade de aprendizagem - que facilite o desenvolvimento de projetos de física e química na escolas e incentive no aluno o pensamento crítico, o uso do método científico, o gosto pela ciência e principalmente a reflexão e compreensão do mundo que o cerca (LABVIRT, 2005).

Essa comunidade de aprendizagem direcionada para professores de Química (no nosso contexto) e alunos do Ensino Médio das Escolas Estaduais de São Paulo, contou com a participação de 6 equipes para dar suporte ao projeto, considerando a estrutura do espaço virtual (website) e seus objetivos estratégicos. Essas equipes constituíram-se em: coordenação, produção de simulações, orientação às escolas e professores, consulta ao especialista, fórum e notícias científicas. Para compor essas equipes tivemos professores-pesquisadores da Universidade de São Paulo, bem como alunos de pósgraduação e de graduação.

Em especial, a equipe de orientação às escolas e aos professores, da qual esta autora fez parte, foi composta por cinco mestrandos do Programa de Pós-graduação Interunidades de Ensino de Ciências - Modalidade Química da Universidade de São Paulo (Instituto de Física, Instituto de Química, Instituto de Biociências e Faculdade de Educação), e tinha como funções: 1) acompanhamento presencial, orientando os professores durante os encontros mensais e visitas às escolas participantes; 2) e acompanhamento à distância, através de atendimento a dúvidas e problemas enfrentados pelos professores via e-mails e ligações telefônicas.

O projeto LabVirt teve como objetivo mais amplo buscar a criação de uma comunidade virtual que auxiliasse na aprendizagem de Ciências e que favorecesse: 1) o "aprender fazendo"; 2) a solução de situações-problema do cotidiano do aluno; 3) o trabalho em grupo; 4) a meta-cognição; 5) a produção de materiais didáticos, neste caso as simulações disponíveis na rede; 6) e o intercâmbio de informações e experiências entre Universidade e escola (FEJES et al., 2005a).

Esperava-se que nessa comunidade virtual de aprendizagem tudo estivesse integrado e que todos aprendessem: os professores são continuamente capacitados e apoiados no processo de mudança pedagógica; os alunos aprendem e exploram os 
conhecimentos não somente como receptores mas também como construtores do conhecimento; os alunos universitários utilizam suas habilidades em situações autênticas e com importância social e os acadêmicos da universidade transmitem conhecimentos às escolas e investigam processos de transformação na educação (FEJES et al., 2005b).

A idéia principal do projeto era permitir que os alunos adquirissem um papel ativo e motivador em relação ao seu processo educacional como autores/criadores de situações que envolvessem os temas curriculares que os professores estavam ensinando, e que suas idéias fossem transformadas em simulações (FEJES et al., 2005c).

Para elaborarem as simulações os alunos identificavam situações-problema do seu cotidiano que deveriam relacionar-se com o conteúdo que estava sendo ensinado pelo professor. No processo de busca para resolver o problema, o conhecimento curricular presente nos livros didáticos seria extrapolado, e com isso o aluno aprenderia de uma forma mais abrangente o conteúdo específico estudado (FEJES et al., 2005b).

Com o projeto LabVirt, esperava-se colaborar para:

- a formação de alunos mais ativos e mais conscientes do seu processo de aprendizagem utilizando trabalhos colaborativos em projetos interdisciplinares suportados pelas novas tecnologias;

- $\quad$ incentivar atitudes científicas em diferentes circunstâncias, dentro e fora da escola;

- $\quad$ buscar superar a dicotomia entre teoria e prática;

- $\quad$ estimular uma visão mais integrada/interdisciplinar do conhecimento.

A hipótese do projeto LabVirt era de que, ao ser desenvolvido na sala de aula, afetaria diretamente não só os alunos, mas, também os professores que, por não estarem acostumados a planejar, orientar e avaliar trabalhos desta natureza, sentiriam a necessidade de valorização e apoio em questões técnicas, pedagógicas e conceituais. Nesse sentido, o professor se despiria da figura do educador e assumiria o papel de aprendiz ativo desse projeto, na medida em que colaboraria com as discussões compartilhando suas experiências e tomaria decisões quanto às ações a serem tomadas.

Para a sua concretização, ocorreram encontros mensais de 8 horas entre as equipes do projeto e os 24 professores participantes. Foram 16 encontros onde:

- compartilharam-se, com professores de Física que trabalhavam com o projeto desde sua implantação, experiências bem sucedidas no LabVirt Física;

- discutiu-se sobre o ensino por projetos e formas de desenvolvê-lo; 
- orientou-se sobre as características específicas do LabVirt;

- conheceram-se metodologias para formar redes colaborativas apoiadas em um ambiente virtual e com isso produzirem simulações;

- refletiu-se sobre a importância do planejamento e conseqüentemente do plano de aulas.

Esperava-se a partir desses encontros, colaborar para que o professor combinasse estratégias e elaborasse um currículo apropriado à realidade de seus alunos, considerando os métodos de ensino e de avaliação, e também que percebessem as dificuldades, as habilidades e as estratégias necessárias para planejarem e trabalharem com esse projeto.

Esses encontros finalizaram em dezembro de 2005 com uma avaliação positiva para o projeto em relação ao aproveitamento, já que quase todos os professores (20) conseguiram trabalhar a partir do LabVirt em sala de aula e 123 simulações foram produzidas por seus alunos. Essas simulações estão publicadas no website do projeto (www.labvirtq.futuro.usp.br) e disponíveis para serem utilizadas por qualquer usuário.

\subsection{A "intervenção" sobre o planejamento}

Dentre os materiais recebidos pelos professores durante o projeto LabVirt havia um "modelo" de plano de aula (Anexo 1), exatamente como acontece nas escolas. Para o desenvolvimento de nosso projeto, porém, sentimos a necessidade de discutir com maior profundidade com esses professores a importância do planejamento frente aos desafios da sua prática docente. Com esse propósito em mente, em um dos encontros mensais com os professores participantes do projeto, proporcionamos uma discussão sobre o planejamento e seus produtos, já que uma das tarefas do professor para aplicação do projeto na sala de aula era reelaborar o seu plano de aulas.

Nesse encontro os professores receberam um material (Anexo 2) que continha dados sobre a importância de planejar as ações, quais as finalidades de um planejamento de ensino-aprendizagem e um roteiro orientador de elaboração de plano de curso e de aula. Essa seção foi mediada pela pesquisadora, gravada em áudio e vídeo e posteriormente transcrita, com a expectativa de que nos forneceria dados sobre as concepções de planejamento desses professores. A transcrição na íntegra das falas dos professores encontra-se no Anexo 3.

Em relação ao roteiro de elaboração do plano de aulas, os professores foram orientados para que o fizessem com o maior detalhamento, já que refletiria o seu "quê fazer" cotidiano. 
Analisamos também exemplos de planos de aula pré-elaborados pelos orientadores do projeto a fim de identificarmos aqueles mais adequados à proposta do projeto e que possibilitavam uma visão real e detalhada da ação daquele professor. Ao final, os professores ficaram com a tarefa de elaborar o seu plano de aulas para trabalharem com a proposta do LabVirt.

Ao longo do ano de 2005, os orientadores do projeto acompanharam os professores a fim de auxiliá-los em suas tarefas e fornecer subsídios que permitissem o trabalho com o projeto, desde recursos materiais até a intervenção e orientação dentro da sala de aula.

\subsection{Coleta e análise de dados}

Esse estudo foi realizado com sete professores - que aqui identificaremos por P1, P2, P3, P4, P5, P6 e P7 - escolhidos aleatoriamente dentre os 24 participantes do projeto. Todos são licenciados em Química, ministram aulas no Ensino Médio da Rede Estadual de Ensino de São Paulo e estão em exercício há mais de 10 anos.

A coleta de dados desta pesquisa se deu num primeiro momento pelo plano do ensino do curso de Química para o Ensino Médio que cada professor havia elaborado em sua escola para o ano letivo, logo no início do projeto, a fim de analisar como o professor tem planejado o seu ensino.

Em seguida, os professores responderam a um questionário com dez questões abertas que versavam sobre o planejamento (Anexo 4). Com o intuito de testar a validade do instrumento, aplicou-se este mesmo questionário previamente a um grupo de 15 professores de Química do Ensino Médio também da Rede Estadual de Ensino pertencentes à Diretoria de Ensino - Sul 1.

A partir de uma breve análise desses instrumentos, entrevistamos sete professores, numa entrevista semi-estruturada (Anexo 5), a fim de esclarecer suas concepções sobre o planejamento de ensino e alguns pontos dúbios tanto no questionário quanto no plano de ensino. O procedimento global de coleta de dados e análise pode ser visualizado na Figura 2.

A partir desses dados, pretendemos responder nossa primeira pergunta de investigação:

a) Qual é a concepção desses professores de Química do Ensino Médio sobre planejamento escolar e como eles elaboram seu plano de curso para sua prática docente? 
Após o encontro para a discussão sobre planejamento, conforme descrito no item 3.2, e decorrido um ano de projeto sendo orientado para a elaboração do plano de aula do LabVirt, aplicamos outro questionário (Anexo 6) com o intuito de pesquisar como o professor considerou sua atuação no projeto LabVirt e quais foram as dificuldades encontradas ou não, tendo como foco as atividades do planejamento.

Por fim, com o término do projeto ao final de 2005, coletamos novamente os planos de ensino do curso que os mesmos professores elaboraram em suas escolas após um ano trabalhando com a proposta do LabVirt, com o objetivo de responder à segunda pergunta da nossa investigação:

b) $O$ projeto LabVirt, como um programa de formação contínua, possibilitará que os professores percebam o plano de ensino não apenas como um rol de conteúdos mas também como um documento imprescindível para sua prática docente, explicitando os objetivos, os procedimentos de ensino, os recursos e a avaliação do processo de ensino-aprendizagem de forma integrada, detalhada, refletindo a realidade da sala de aula? 


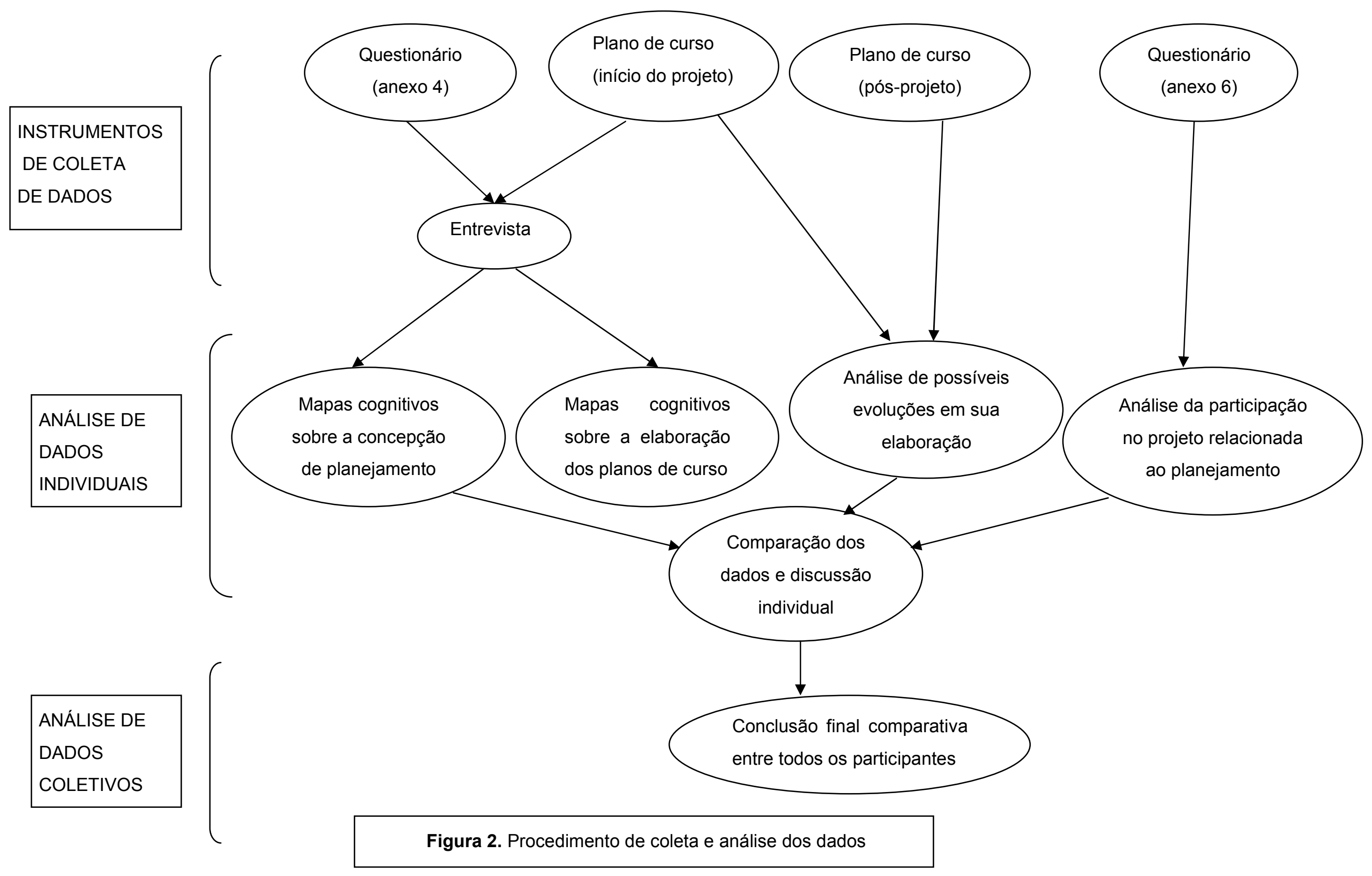




\subsubsection{Análise qualitativa}

A pesquisa qualitativa, já há algum tempo muito utilizada no campo educacional, é caracterizada segundo Bogdan e Biklen (1994) pelos seguintes aspectos: 1) a pesquisa qualitativa tem o ambiente natural como sua fonte direta de dados e o investigador é o instrumento principal; 2) tende a ser mais descritiva; 3) há um maior interesse pelo processo do que pelos resultados ou produtos; 4) os pesquisadores tendem a analisar os dados de forma indutiva; 5) e o significado é de importância vital.

Esse método de investigação costuma ser direcionado e não busca enumerar ou medir eventos, não utilizando, então, instrumental estatístico para análise dos dados.

O nosso trabalho vai se fundamentar nessa análise qualitativa dos dados. Para analisar os questionários e entrevistas, utilizamos o procedimento descrito por Miles e Huberman (1984) (Figura 3), que se distingue em três atividades a partir da coleta de dados:

a) Redução de dados: que se refere ao processo de seleção, concentração, simplificação, abstração e transformação de dados novos. É um processo que ocorre continuamente ao longo da pesquisa qualitativa. Esse processo permitiu a seleção e categorização dos dados obtidos nas entrevistas e questionários.

b) Exposição dos dados: um agrupamento de informações organizado que permitirá a elaboração de conclusões. A exposição dos dados é uma ótima maneira para validar dados qualitativos e pode ser desenvolvida através de matriz, gráfico, rede ou tabela. A exposição faz parte da análise, pois para representar as linhas e colunas de uma tabela e decidir quais dados e de que forma devem constar nas células, acaba sendo necessária uma atividade de análise. Este procedimento permitirá a criação de tabelas sobre a elaboração dos planos dos professores e a elaboração dos mapas cognitivos a partir dos questionários e entrevistas. Os mapas cognitivos são um modo de organizar os dados que se possuem e, portanto, uma forma de facilitar as reflexões que podem levar à geração de uma explicação para os dados obtidos (LLINARES, 1992).

c) Extração de conclusões e verificação: envolve extrair significados dos dados expostos, notificando regularidades, padrões, explicações, possíveis configurações, etc. Essas conclusões são também verificadas, testadas por sua plausibilidade, coerência e validade. A partir desse processo foi possível traçar um paralelo entre as concepções dos professores e suas ações no planejamento. 


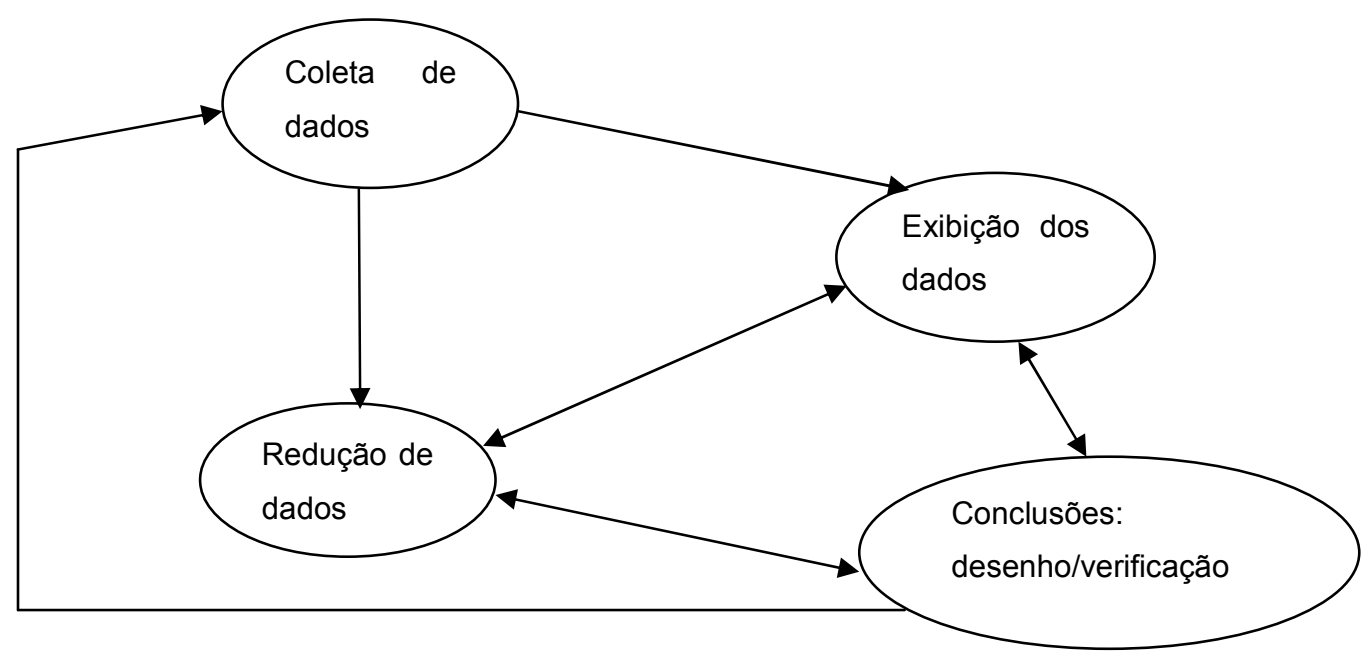

Figura 3. Componentes da análise dos dados (MILES e HUBERMAN,1984).

\subsubsection{Mapas cognitivos}

Os mapas conceituais, atualmente muito utilizados como instrumento para melhorar e avaliar os processos de ensino-aprendizagem de Ciências, foram elaborados por Joseph D. Novak a partir de seus estudos na Cornell University em 1975, baseado nas teorias de David Ausubel. Têm como idéia chave a natureza da aprendizagem significativa em contraste com a aprendizagem memorística (GONZÁLEZ GARCIA, 1992).

Segundo González Garcia (1992), Ausubel considera como princípio da aprendizagem significativa a idéia de que cada um de nós tem uma seqüência única de experiências de aprendizagem e conseqüentemente adquire significados idiossincráticos para os conceitos.

A construção de conceitos sobre um determinado tema se faz através do conhecimento que temos sobre este tema resultando num sistema coerente e ordenado de concepções. Esse sistema pode ser simbolizado por mapas conceituais, uma representação visual da hierarquia e das relações entre os conceitos contidos na mente, mais especificamente os conceitos científicos (NOVAK e GOWIN, 1988).

Essa metodologia vem sendo amplamente utilizada e validada (GONZÁLEZ et al., 2004) para representar as estruturas de conhecimentos dos estudantes para identificar e intervir nas concepções alternativas, para planejar unidades didáticas e propostas curriculares, para resolução de problemas, entre outros.

Entretanto, Novak e Gowin (1988), em seus estudos sobre aprendizagem significativa através dos mapas conceituais utilizaram como método de análise das 
transcrições das entrevistas os mapas cognitivos, por considerarem que estes refletem os conceitos e proposições revelados por cada estudante durante a entrevista.

Mapa cognitivo é o termo com o qual designamos a representação do que acreditamos que é a organização dos conceitos e proposições na estrutura cognitiva de um estudante determinado. Os mapas cognitivos são idiossincráticos, enquanto que os mapas conceituais devem representar uma área de conhecimentos da maneira que considerariam válida os especialistas no tema (NOVAK e GOWIN, 1988).

A partir dessa definição podemos concluir, junto com Ontoria et al. (2001), que mapas conceituais e mapas cognitivos possuem significados diferentes.

O termo mapa cognitivo foi usado pela primeira vez por Tolman, psicólogo neoconducista, em 1948, para descrever como ratos e, por analogia, humanos comportavam-se em seu meio ambiente (KITCHIN, 1994). Ele elaborou a hipótese de que nós construímos uma representação em forma de mapas dentro da "caixa preta" do sistema nervoso que é usado para guiar nossos movimentos cotidianos.

Downs e Stea citado em Ontoria et al. (2001) apresentaram a definição de mapa cognitivo mais tradicional usada e aceita pelos pesquisadores que diz que mapa cognitivo é um processo composto de uma série de transformações psicológicas pelo qual um indivíduo adquire, armazena, relembra e decodifica informações sobre os atributos e localizações relativas de um fenômeno em seu ambiente espacial cotidiano.

Assim, podemos destacar o caráter individual e psicológico do mapa cognitivo, frente ao caráter social e lógico do mapa conceitual. Para Novak, fora da psicologia ambiental, há a possibilidade de diversos mapas cognitivos corretos sobre um mesmo conteúdo informativo, devido à grande variedade de organizações que se pode dar entre um mesmo bloco de conceitos (ONTORIA et al., 2001).

O mapa conceitual sobre as idéias prévias ou estruturas cognitivas existentes no indivíduo antes de submeter-se a uma informação nova, seria um mapa cognitivo. A esta mesma categoria pertencem os mapas de pré-conceitos dos alunos das primeiras etapas evolutivas (ONTORIA et al., 2001).

Os mapas cognitivos vêm sendo utilizados então como procedimento de análise em pesquisas que se utilizam de questionários e entrevistas com dados (RUIZ et al., 
2005; GONZÁLEZ, 2004; MELLADO et al., 2002; MELLADO, 1998; 1997; 1996) por facilitar a visualização e interpretação dos dados.

Llinares (1992), em seu estudo sobre as crenças epistemológicas dos professores, utilizou os mapas cognitivos como instrumento de análise por entender que estes são uma representação gráfica das conexões entre os componentes do sistema de crenças e representam um método para modelar estas crenças de forma esquemática.

Utilizaremos a técnica proposta por Llinares para a elaboração dos mapas cognitivos como método de análise de nossos dados. O procedimento, através da análise do conteúdo, pode ser assim descrito:

a) Determinação de unidades de análise: podem ser desde palavras a símbolos ou proposições semânticas (frases ou conjunto delas) com um sentido próprio. Consideram-se como unidades de análise os segmentos de conteúdo com sentido relacionado ao motivo da análise.

b) Desenvolvimento de um processo de codificação para cada unidade de análise: os códigos são uma abreviação ou símbolo que se aplica a uma unidade de análise para classificá-la. Este processo é guiado por dois princípios fundamentais:

- os códigos devem estar relacionados com a natureza dos dados e;

- a teoria e as questões planejadas na investigação são as que devem guiar o processo de codificação e portanto determinar o conteúdo das categorias.

As unidades de análise selecionadas estão demonstradas na transcrição das entrevistas e no questionário pré-projeto que constam nos anexos.

Durante a geração dos sistemas de categorias se identificarão conexões implícitas entre os componentes das concepções. O passo seguinte no processo de análise é mostrar graficamente essas conexões, ou seja, proceder à construção dos mapas cognitivos como um meio de mostrar essas relações.

\subsubsection{As categorias de análise}

A partir da análise do questionário 1 e da entrevista, identificamos diversas unidades de informação para cada professor pesquisado. As unidades de informação nos guiaram para a elaboração das seguintes categorias apresentadas na Tabela 1 que serão base para a construção dos mapas cognitivos. 
Tabela 1. Categorias de análise

\begin{tabular}{|l|l|}
\hline \multicolumn{2}{|c|}{ CATEGORIAS } \\
\hline \multirow{4}{*}{ A. DO PLANEJAMENTO } & A.1. Significado e finalidade \\
\cline { 2 - 3 } & A.2. Importância \\
\cline { 2 - 2 } & A.3. Processo \\
\cline { 2 - 2 } & A.4. Referências bibliográficas \\
\hline \multirow{2}{*}{ B. DO PLANO DE CURSO } & B.1 Pré-requisitos para a \\
\cline { 2 - 2 } & B.2. Características do plano \\
\cline { 2 - 2 } & B.3. Seleção de conteúdos \\
\cline { 2 - 2 } & B.4. Avaliação diagnóstica \\
\hline
\end{tabular}




\section{RESULTADOS E DISCUSSÃO}

\subsection{Da orientação sobre planejamento}

O encontro com os 24 professores de Química que participavam do projeto LabVirt aconteceu na sede da Escola do Futuro no campus da Universidade de São Paulo durante um período de 8 horas. Para a discussão sobre planejamento reservamos toda a manhã (4 horas).

Nessa conversa mediada pela pesquisadora, discutimos conceitos e procedimentos sobre o planejamento, avaliamos planos de aulas e os professores iniciaram a elaboração do plano de aulas para trabalhar com o projeto LabVirt com seus alunos. Essa atividade foi gravada e sua transcrição na íntegra encontra-se no Anexo 3.

Ao longo das atividades pudemos verificar a fragilidade de alguns quanto aos seus saberes sobre o planejamento. Eles criticam a maneira como é posta a elaboração desse plano nas escolas e assumem que o elaboram "também" por motivos burocráticos, ...têm alguns momentos em que a gente até pensa nessa parte burocrática..., ...eu entrego porque o meu coordenador pede... O fato de algumas escolas imporem um formulário próprio para registrar o planejamento torna este processo ainda mais burocrático. O que deveria ser de autoria do professor já vem instituído e este deve adequar o seu trabalho a uma forma rígida e pré-definida. Na minha escola temos que fazer (o plano) naquele papelzinho. Desta vez a coordenadora deu a planilha em um disquete [...] para que ela passe para o computador na hora de fazer o Plano Diretor.

Junto a isso, a falta de conhecimento teórico sobre "como fazer", "porquê fazer" também é um impedimento para a elaboração do plano, ...na realidade ninguém sabe planejar..., ...fazemos isso automaticamente porque não temos muitas informações bibliográficas sobre planejamento..., de uma forma mais consciente e refletida. Reconhecem ainda que por si sós poderiam buscar essas referências, mas apontam a falta de tempo como um complicador para essa busca.

Quando apontada pela orientadora a necessidade de se planejar por área do conhecimento (Química, Física, Biologia e Matemática), os professores explicam os motivos que justificam a ausência desse planejamento em suas escolas. São raras as escolas que, no momento do planejamento e do replanejamento, reservam este para um planejamento efetivo. Vários assuntos referentes à Unidade Escolar são tratados e somente no final desses momentos é que os professores podem pensar em seus cursos. Então não resta muito tempo para os professores discutirem seus currículos por área. ...quando a gente tem o tempo do planejamento no início e no meio do ano, que são os dias que se tem mais tempo para isso, eu acho que se perde muito tempo com 
discussões que não levam a nada, [...] e a gente não tem tempo para realmente fazer aquilo que gostaria.

Como conseqüência, continuamos com o currículo compartimentado, sem sentido para o aluno. E, pior ainda, em escolas onde há mais de um professor da mesma disciplina, estes planejam coisas diferentes para a mesma série de um mesmo período ou, então, se lecionam em séries diferentes, o currículo não é linear, com um objetivo único. Pode acontecer de os dois professores estarem ensinando o mesmo conteúdo em séries diferentes. [...] têm três professores de Química na casa. Professores de biologia, têm cinco. Um dá aula para duas salas, outro dá aula para três salas. O conteúdo não bate com nada... cada um vai por si e pronto. Isso pode acontecer também pelas diferentes concepções de cada professor, ...a professora que dá aula nas segundas séries também, não concorda com a forma com que eu trabalho e obviamente que eu não vou concordar com a forma com que ela trabalha. De acordo com esse fato, percebemos uma postura egoísta da professora ao pensar somente nela e em sua forma de trabalho. O aluno e sua possível aprendizagem não são o seu foco principal. Isso mostra a necessidade de a escola ter uma Diretriz maior e o professor que estiver nela deve pensar no seu trabalho a partir dessa Diretriz, neste caso o Plano PolíticoPedagógico.

$\mathrm{E}$ ainda, o professor diz que se não há como avaliar o resultado desse planejamento não tem sentido fazê-lo, ...para que eu vou planejar se não consigo medir o resultado desse planejamento...tanto faz se deu certo ou se não deu certo o trabalho naquela classe... Parece que ele necessita de um acompanhamento externo quando coloca que ...se eu planejar que vou dar Química geral e der ou não der, não vai acontecer absolutamente nada, se eu der e os resultados forem negativos, também não vai acontecer nada... e mais ...não tem suporte de ninguém, ninguém te dá apoio, ninguém te dá um acompanhamento... Então se não há cobranças quanto ao plano por parte da direção ou da coordenação pedagógica, eles não vêem sentido em elaborá-lo com qualidade. Então, para que dê certo há uma necessidade de apontamentos por parte da coordenação de que caminho tomar ...o coordenador pedagógico acaba não dando todo o suporte pedagógico que a gente precisa...

Assim fica claro que o planejamento é elaborado apenas para a escola. Ele não percebe que o fato de ter dado certo ou não um trabalho realizado é um dado importante para avaliar o seu trabalho e repensar o seu plano, sua prática.

Em relação ao cumprimento do plano, as propostas de projetos sugeridas pela Secretaria de Estado da Educação são apontadas como um dos fatores a serem considerados. Ao longo do ano, muitos projetos são propostos para as escolas e estas, para cumpri-los, precisam adequá-los ao seu plano. Neste caso, há uma necessidade de 
excluir conteúdos pelo excesso de assuntos a serem tratados ...aí você é obrigado a tirar coisas que você julga importante [...] porque não vai dar tempo...

Os professores criticam esse modelo, julgando como mal organizado. A sugestão é que esses projetos já fossem apontados no início do ano para que o planejamento sofra poucas interferências ...o sistema é mal organizado, porque os projetos que vêm no decorrer do ano nós já deveríamos saber no começo para poder fazer o nosso planejamento. E na verdade a gente não sabe. Então, de repente, você está dando uma coisa, tem que parar porque tem que realizar o projeto. Então já vem do sistema esse mau planejamento.

Junto a isso, os conhecimentos prévios dos alunos para determinado conteúdo também contribuem para a seleção de conteúdos ...eu não vou dar isso porque tem todos esses pré-requisitos que eu sei que eles não têm, e nem eu tenho tempo para parar e resgatar essas coisas. Por isso, culpam a falta de conhecimentos prévios que deveriam ter sido aprendidos em outras disciplinas, pelo insucesso na Química ...eles estão vindo cada vez mais com dificuldades, e a Química que eu acho que usa português, matemática diretamente e física muitas vezes, não está conseguindo dar conta de todos os conteúdos, então você começa a selecionar...

Complementando, o reduzido número de aulas destinado à Química, 2 aulas por semana (no curso noturno, 1 aula) promoveram um achatamento no currículo de Química em relação a tempos atrás quando havia de 3 a 4 aulas de Química na grade horária.

Por outro lado, o mesmo grupo coloca o que planeja para acompanhar o andamento do processo ...eu planejo para minha ação, porque eu preciso ter na mente que andamento eu vou ter, ao longo do período eu vou checando algumas coisas que eu vi ser importantes...

E ainda, que para elaborar o plano de ensino é necessário ...fazer uma previsão de necessidades dessa turma, [...] fazer uma seleção de conteúdos para essa necessidade, prevendo o tempo que eu tenho, os recursos disponíveis que eu tenho na escola, tudo isso eu vou ter que pensar logo no início do ano e ver a situação. Aquela avaliação diagnóstica de conhecimento dele mesmo para também não vir tentar fazer grandes coisas e aí parar porque viu que não vai dar mesmo. Então, tudo isso são coisas que a gente tem que pensar no momento da avaliação, com etapas bem definidas do que a gente quer, e sem esquecer do momento de avaliação para ver se o que eu pensei está de acordo, está dando certo ou não, aonde eu errei, o que aconteceu, para eu planejar isso de novo. Este professor, que também é coordenador pedagógico, tem uma visão mais ampla do planejamento já que aponta várias etapas desse processo tendo como foco principal as necessidades da turma para a qual irá planejar. 


\subsection{De cada professor}

A fim de organizar a exposição dos dados de forma que estes permitam fornecer uma visão do processo de cada professor, iremos dispô-los da seguinte maneira:

A. Dados sobre a concepção de planejamento (mapas cognitivos construídos a partir do questionário aplicado ao início do projeto, Anexo 4).

B. Dados sobre a elaboração do plano de curso (mapas cognitivos construídos a partir das entrevistas semi-estruturadas, Anexo 5).

C. Os planos de curso pré e pós-projeto.

D. Dados do questionário pós-projeto (Anexo 6).

E. Discussão dos dados (individualmente).

\subsubsection{Professor $P 1$}

\section{A. Dados sobre a concepção de planejamento}

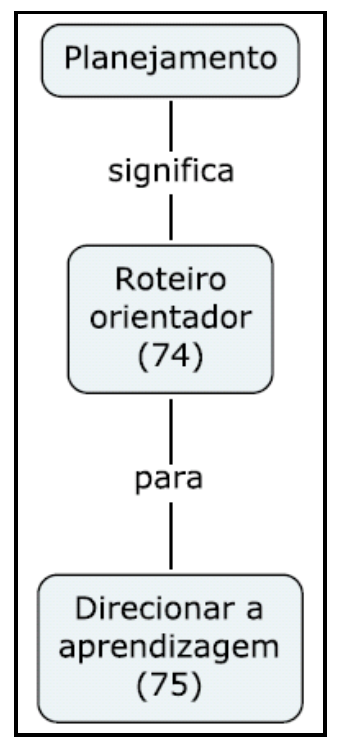

MC1. Planejamento_significado e finalidade de P1 


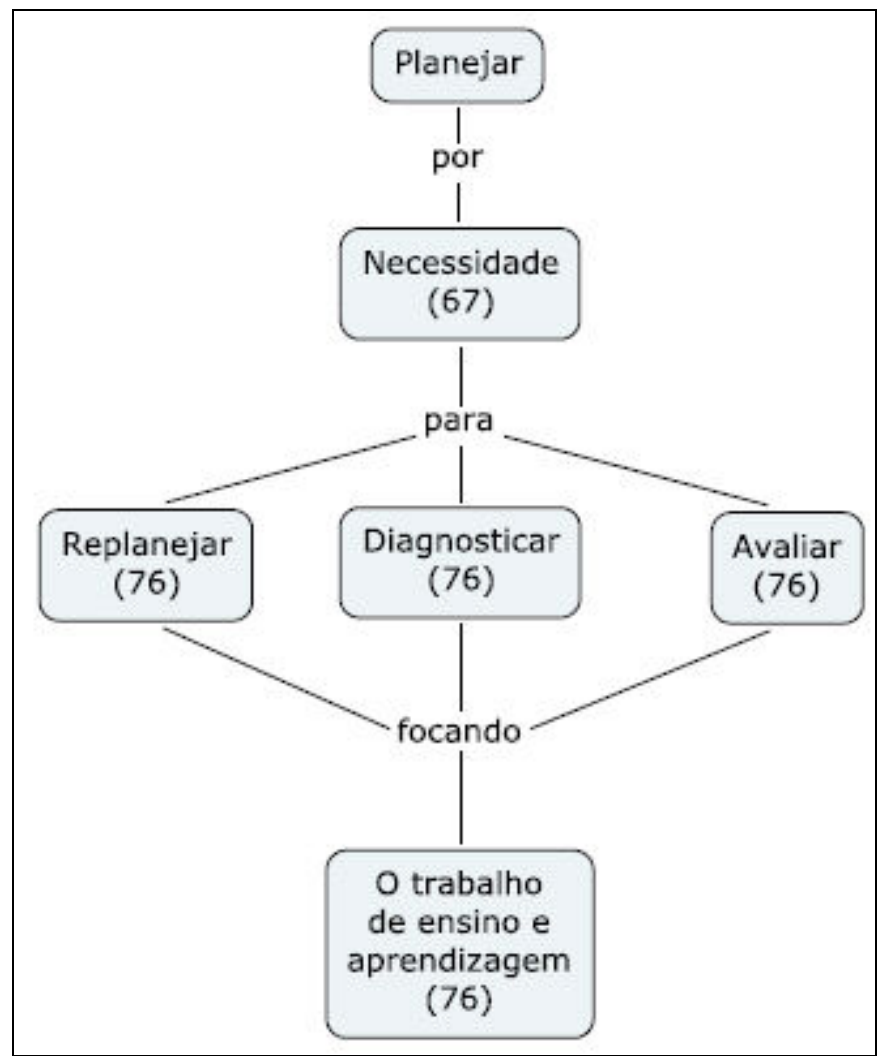

MC2. Planejamento_importância de P1

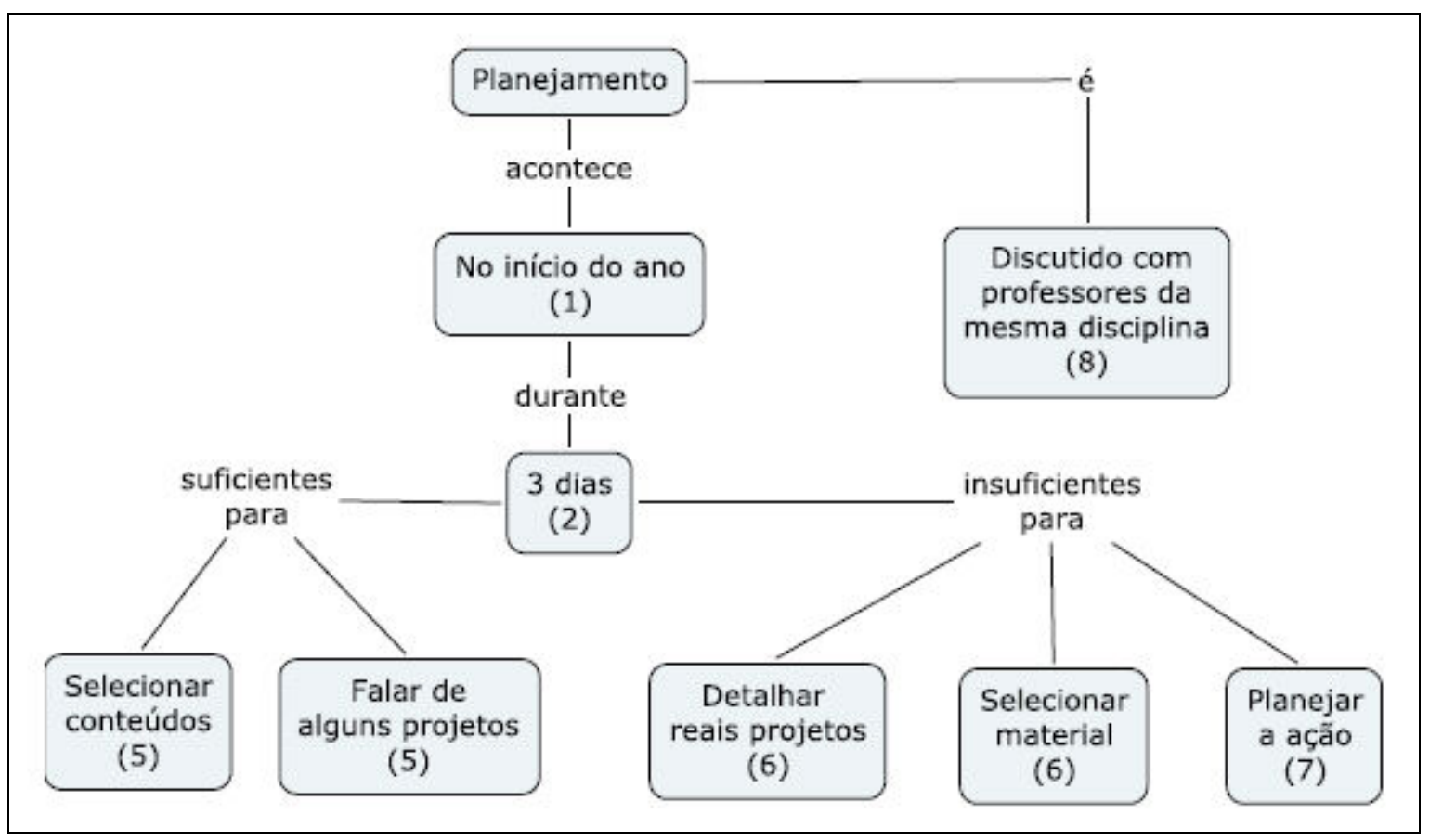

MC3. Planejamento processo de P1 


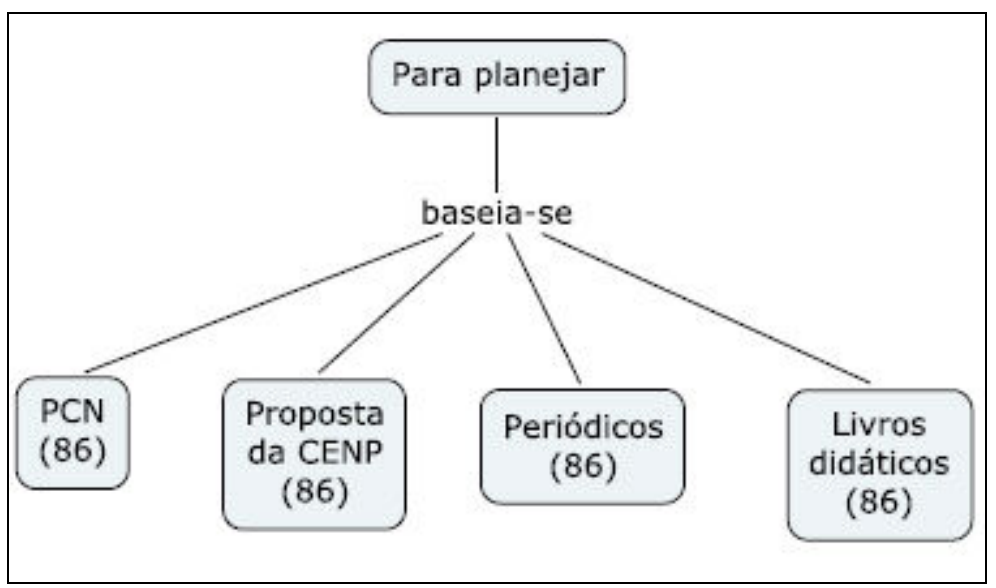

MC4. Planejamento_referências bibliográficas de P1

Em relação às concepções sobre planejamento de ensino, o professor $\mathrm{P} 1 \mathrm{o}$ concebe como um direcionador do ensino-aprendizagem, como um roteiro orientador a fim de organizar o ensino. Este sente a necessidade de elaborá-lo, pois é a partir do planejamento que poderá replanejar e avaliar seu trabalho. O planejamento em sua escola acontece no início do ano durante 3 dias, tempo suficiente para a seleção de conteúdos e a discussão superficial dos projetos da escola. Ao mesmo tempo, este professor considera o tempo insuficiente para uma discussão mais aprofundada dos projetos e para selecionar os materiais necessários ...isso daí eu acho que é a falha. É aquele tempo para estar planejando a ação. Apesar dos professores da disciplina estarem juntos nesse momento, a metodologia do processo de ensino-aprendizagem não é discutida com seus pares. Suas referências para elaborar seu plano são os documentos oficiais, artigos científicos e livros didáticos. E a partir dos conteúdos que esses materiais propõem ainda há uma seleção considerando a realidade da escola ...a grade curricular, a realidade da comunidade também, qual que é a situação que a comunidade vive. 
B. Dados sobre a elaboração do plano de curso

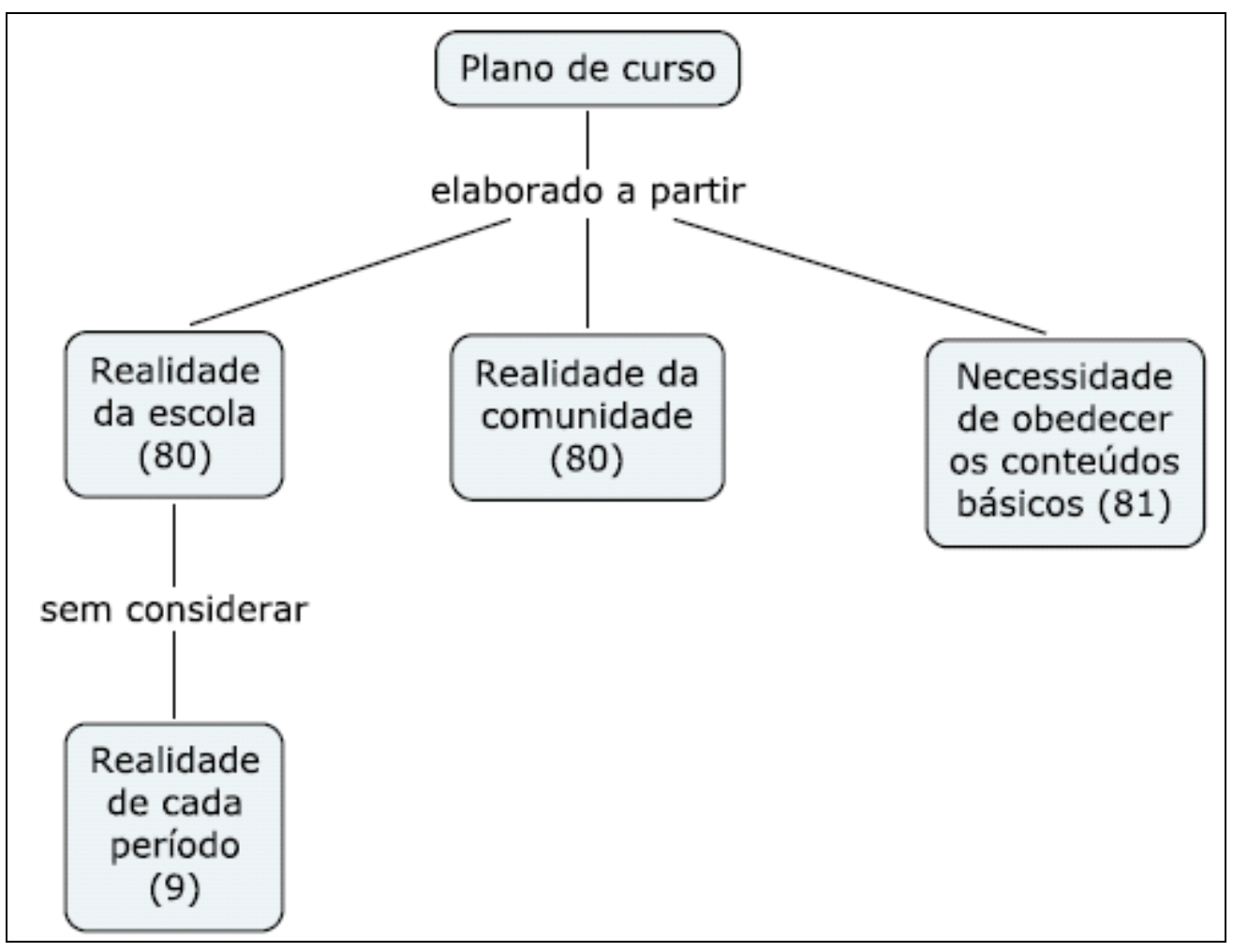

MC5. Plano de curso_pré-requisitos de P1

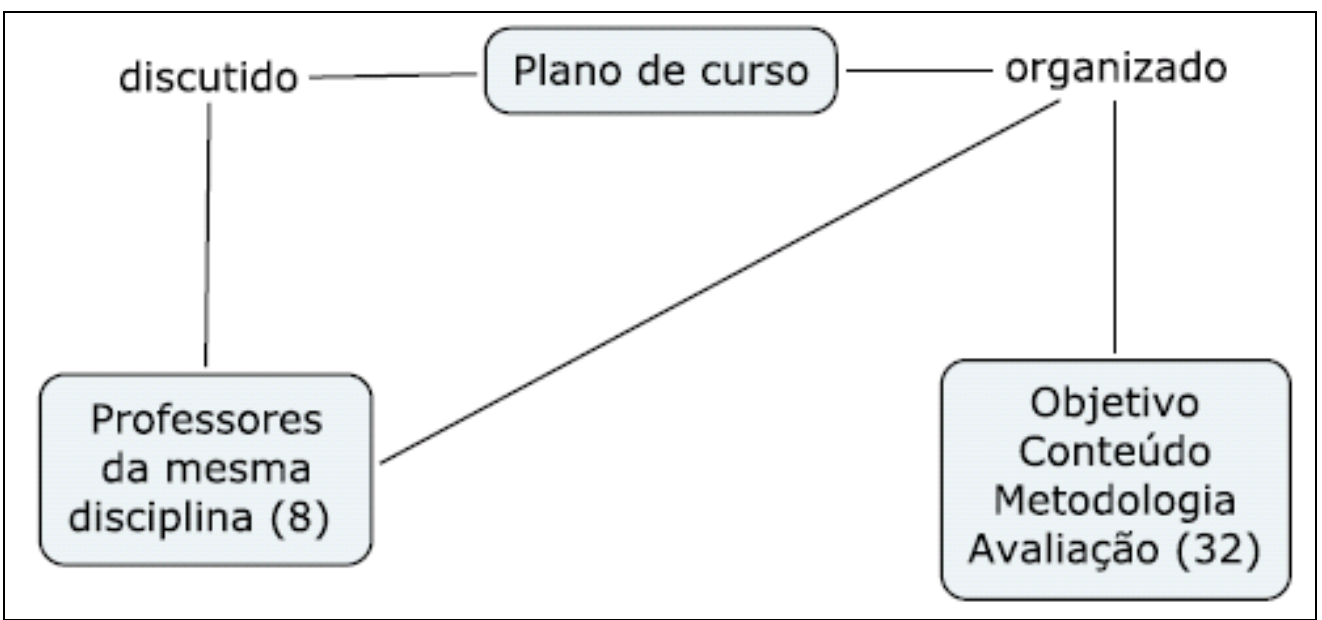

MC6. Plano de curso_características de P1 


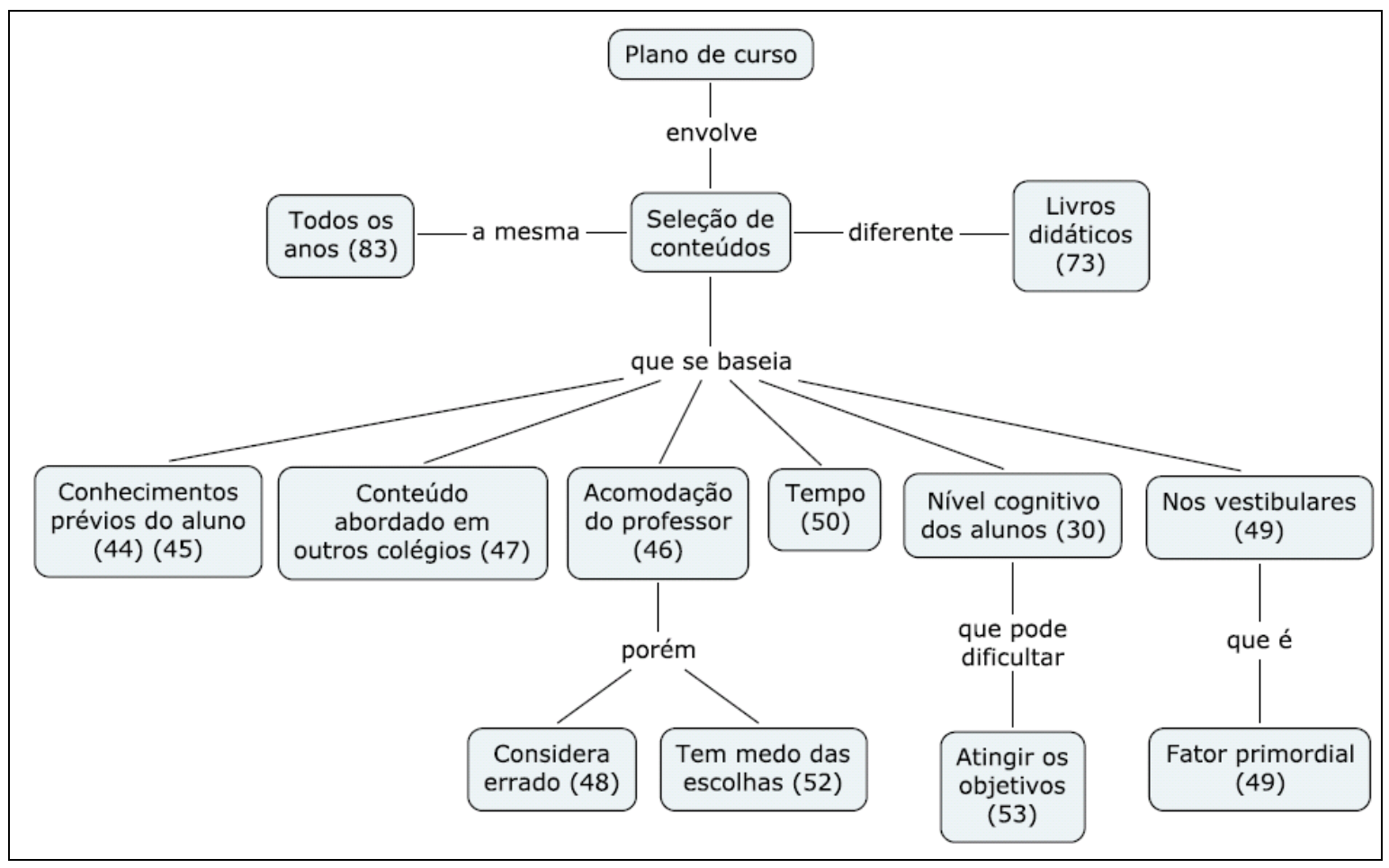

MC7. Plano de curso_seleção de conteúdos de P1

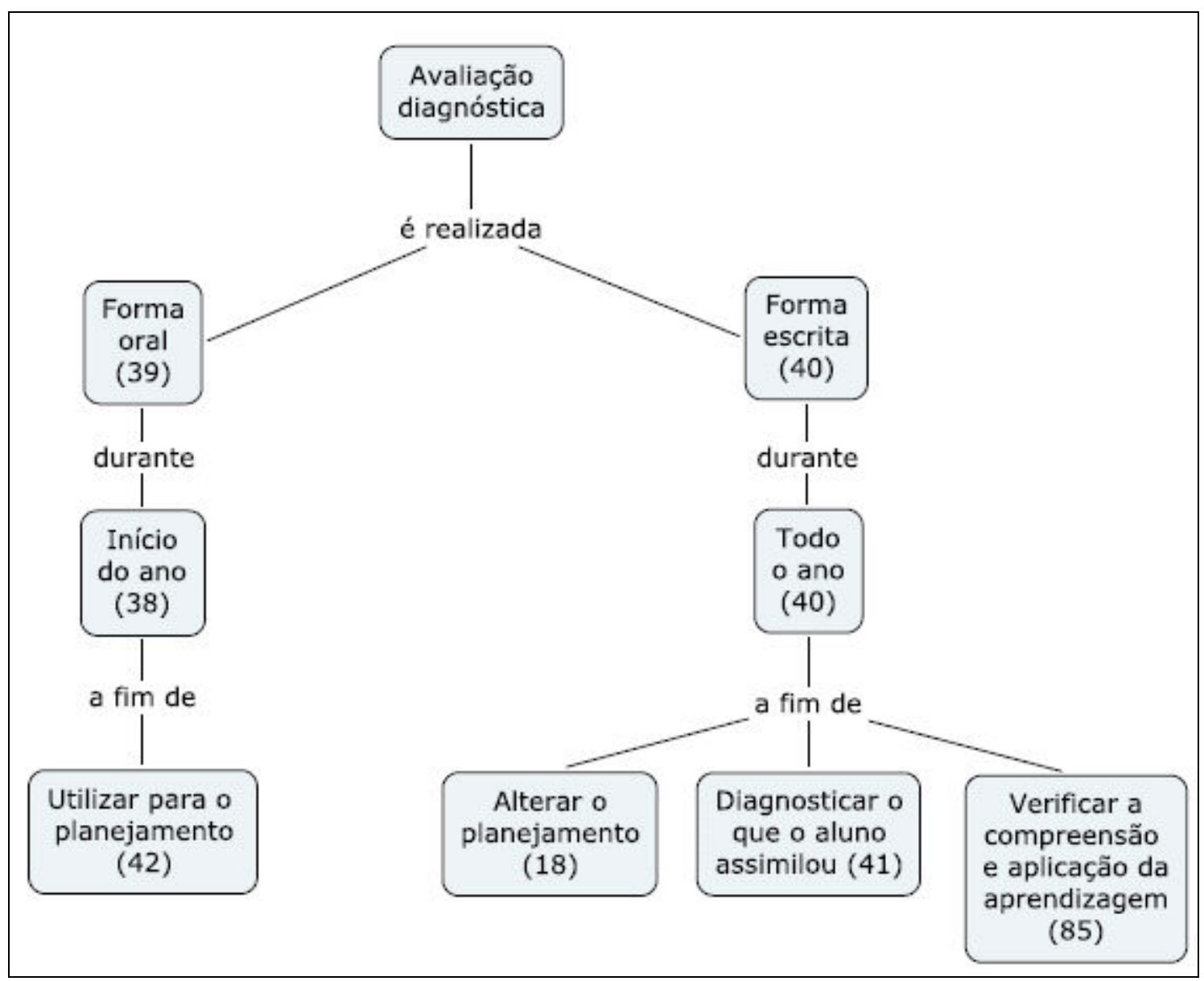

MC8. Plano de curso_avaliação diagnóstica de P1 
Para a elaboração do plano de curso o professor P1 considera a realidade da escola e da comunidade juntamente com uma avaliação diagnóstica não formal, o que entendemos como uma sondagem. Para ele o plano deve ser organizado de uma forma padrão entre as escolas, em tópicos (objetivos, conteúdos, metodologia e avaliação), e deve ser discutido por todos os professores de Química dessa escola.

Em relação à concepção sobre a seleção de conteúdos, o professor $\mathrm{P} 1$ demonstra em suas respostas certa insegurança frente à escolha dos conteúdos, no sentido de estar prejudicando o aluno ao inovar seu currículo.

Então, a seleção desses conteúdos está baseada no que considera ser básico para cada série, sendo os mesmos todos os anos, porém são diferentes da seqüência dos livros didáticos. Básicos para ele são aqueles pedidos nos vestibulares (primordial) e aqueles que as outras escolas também ensinam. Entre os conteúdos básicos, são selecionados aqueles que o professor terá tempo de ensinar, que são cômodos para o professor e que os alunos conseguirão aprender considerando o nível cognitivo dos mesmos.

Assim, fica claro que se ele considera que o aluno não terá condições de aprender tal conteúdo porque Ihe faltam conhecimentos prévios para isso, esse conteúdo então é excluído do planejamento. Ao mesmo tempo, ele assume ser errado o professor fazer essas escolhas ao seu "bel prazer".

Percebe-se também uma grande influência dos exames vestibulares quando diz “... só que teve um fator primordial, que foi aqueles (conteúdos) que são mais necessários, ou seja, pedidos na maioria dos vestibulares".

A avaliação diagnóstica é utilizada ao longo do ano, pois permite replanejar, verificar o que o aluno assimilou e compreendeu do que foi estudado.

\section{Os planos de curso pré e pós-projeto}

Dos planos de curso foram omitidos somente o nome da escola e dos professores, todo o restante do conteúdo está exatamente como os originais.

\section{Plano Anual de 2005}

\section{Componente Curricular: Química}

Série: $1^{\mathrm{a}}, 2^{\mathrm{a}}$ e $3^{\mathrm{a}}$ séries do Ensino Médio (MANHÃ E NOTURNO)

Professores: P1, P2 e P3 


\section{OBJETIVOS GERAIS}

Objetivando-se que o ensino de Química não se resuma em uma simples transmissão de conteúdos, mas na aquisição, por parte do aluno, de conteúdos contextualizados, isto é, que tenham significação humana social, propõe-se então, que se tome como ponto de partida a situação de interesse imediato do aluno, o que ele vive, conhece ou sofre influências e que se atinjam os conhecimentos químicos historicamente elaborados de modo que lhe permitam compreender e desenvolver uma consciência, mais plena de suas responsabilidades e direitos juntamente com o aprendizado disciplinar.

\section{CONTEÚDO}

\section{$1^{\circ}$ COLEGIAL}

. A História da Ciência e o ensino de Química

. O cotidiano no ensino de Química

. Química - Noções Fundamentais

. O átomo - Da História à sua Constituição

. Elementos Químicos - Classificação Periódica

. Ligações Químicas - Formação de Substâncias

. Reações Químicas - Transformações de Substâncias

. Funções Inorgânicas - Noções Fundamentais

\section{$2^{\circ}$ COLEGIAL}

. Reações Químicas

. Cálculos Químicos

. Funções Inorgânicas

. Físico- Química - Misturas Homogêneas e Heterogêneas

. Soluções

. Energia Térmica

. Cinética Química

\section{COLEGIAL}

. Gases - Estudo do Comportamento Físico Cálculos Químicos 
- Química Orgânica

Carbono

Funções Orgânicas

Isomeria

Diferenciação de Compostos Orgânicos

Produtos Orgânicos

Compostos Orgânicos - Fontes Naturais e Processos de Preparação Importância Biológica e Importância Industrial

\section{III - METODOLOGIA}

. Aulas expositivas

. Resolução de exercícios individuais e em grupo

. Debates

. Pesquisas

. Experimentos em sala de aula, sala de vídeo, sala de informática

. Excursões

. Seminários

. Textos de jornais e revistas

IV - AVALIAÇÃO

. Avaliação contínua

. Resolução de exercícios individuais e em grupo

. Trabalhos individuais e em grupo

. Relatórios

. Seminários

. Assiduidade

. Pontualidade

. Participação e interesse em todas as atividades desenvolvidas em sala de aula . Avaliação individual / dupla

\section{V - ESTUDOS DO MEIO}

. Exposições e Eventos ligados ao conteúdo.

. Exposições e Eventos ligados aos temas transversais.

. Parques Temáticos 
. Visitas às Empresas e /ou Indústrias Químicas relacionadas ao conteúdo.

VI - PROJETOS

. Labvirt

. Feira de Ciências

VII - BIBLIOGRAFIA BÁSICA

. USBERCO, João e SALVADOR, Edgard. Química Essencial. São Paulo. Ed. Saraiva.

. PERUZZO, Tito Miragaia e CANTO, Eduardo Leite. Química: Na Abordagem do Cotidiano. São Paulo. Ed. Moderna.

. COSTA, Maria Claudia e SANTOS, Gilson Oliveira. Química: A Visão do Presente. Belo Horizonte. Ed. Lê.

- Apostila POSITIVO

OBSERVAÇÃO: Serão consultados sites de Jornais e livros do acervo da biblioteca

São Paulo, Maio de 2.005

\section{Plano Anual de 2006}

\section{Componente Curricular: Química}

\section{Série: $1^{a}$. Série do Ensino Médio}

Professor(s): P1 e P2

\section{OBJETIVO GERAL}

Objetivando-se que o ensino de Química não se resuma em uma simples transmissão de conteúdos, mas na aquisição, por parte do aluno, de conteúdos contextualizados, isto é, que tenham significação humana social, propõe-se então, que se tome como ponto de partida a situação de interesse imediato do aluno, o que ele vive, conhece ou sofre influências e que se atinjam os conhecimentos químicos historicamente elaborados de modo que lhe permitam compreender e desenvolver uma consciência, mais plena de suas responsabilidades e direitos juntamente com o aprendizado disciplinar. 


\section{OBJETIVOS ESPECÍFICOS}

\section{PRIMEIRO BIMESTRE}

. Analisar a importância da Química para enfrentar os desafios da sociedade,

.Compreender que a ciência Química é experimental e a metodologia científica é a sua ferramenta,

.Correlacionar a transitoriedade dos modelos científicos com a sua evolução e a exigência de novas teorias,

. Reconhecer macroscopicamente os três estados da matéria associando suas características com modelos microscópicos,

. Explicar que a constância de algumas propriedades físicas e químicas pode servir como critério de pureza das substâncias.

\section{SEGUNDO BIMESTRE}

. Reconhecer que o modo como os elementos químicos estão agrupados na tabela periódica nos permite prever como algumas propriedades variam nos grupos e nos períodos,

. Reconhecer as principais diferenças entre metais e ametais,

. Reconhecer que as ligações químicas se estabelecem pela união entre átomos por meio da interação dos elétrons da camada de valência,

.Propor explicações microscópicas para as propriedades dos compostos iônicos, moleculares e metálicos.

. Prever a natureza polar ou apolar das ligações químicas.

\section{TERCEIRO BIMESTRE}

. Reconhecer a ocorrência de uma reação química por meio da observação visual

. Prever a ocorrência de reações químicas a partir dos reagentes.

\section{QUARTO BIMESTRE}

- Interpretar por meio de modelos microscópicos, os experimentos de condutibilidade elétrica realizada por Arrhenius

. Nomear, escrever as fórmulas e apresentar as principais aplicações para alguns ácidos, bases e sais. 
- Descrever os principais óxidos presentes na crosta terrestre, no mar e na atmosfera.

- Avaliar o papel dos óxidos na poluição atmosférica e no fenômeno do aquecimento global.

\section{CONTEÚDO}

\section{$1^{\circ}$ COLEgial}

. A História da Ciência e o ensino de Química

. O cotidiano no ensino de Química

. Química - Noções Fundamentais

. O átomo - Da História à sua Constituição

. Elementos Químicos - Classificação Periódica

. Ligações Químicas - Formação de Substâncias

. Reações Químicas - Transformações de Substâncias

. Funções Inorgânicas - Noções Fundamentais

\section{$2^{\circ}$ COLEGIAL}

. Funções Inorgânicas - Noções Fundamentais

. Átomos e Moléculas - Massas e Números de Partículas

. Gases - Estudo do Comportamento Físico

Cálculos Químicos

. Físico- Química - Misturas Homogêneas e Heterogêneas

. Soluções

. Energia Térmica

. Cinética Química

. Oxirredução

. Pilhas

. Eletrólise

\section{$3^{\circ}$ COLEGIAL}

. Radioatividade Natural e Artificial

. Química Orgânica

Carbono 


\author{
Funções Orgânicas \\ Isomeria \\ Diferenciação de Compostos Orgânicos \\ Produtos Orgânicos \\ Compostos Orgânicos - Fontes Naturais e Processos de Preparação \\ Importância Biológica e Importância Industrial
}

\title{
VI - METODOLOGIA
}

. Aulas expositivas

. Resolução de exercícios individuais e em grupo

. Debates

. Pesquisas

. Experimentos em sala de aula, sala de vídeo, sala de informática

. Excursões

. Seminários

. Textos de jornais e revistas

\section{V - AVALIAÇÃO}

. Avaliação contínua

. Resolução de exercícios individuais e em grupo

. Trabalhos individuais e em grupo

. Relatórios

. Seminários

. Assiduidade

. Pontualidade

. Participação e interesse em todas as atividades desenvolvidas em sala de aula

. Avaliação individual / dupla

\section{VI - ESTUDOS DO MEIO}

. Exposições e Eventos ligados ao conteúdo.

. Exposições e Eventos ligados aos temas transversais.

. Parques Temáticos

. Visitas às Empresas e /ou Indústrias Químicas relacionadas ao conteúdo. 


\section{VII - PROJETOS}

. Ler e Escrever prá Valer

. São Paulo 450 anos

. Feira de Ciências

\section{VIII - BIBLIOGRAFIA BÁSICA}

. USBERCO, João e SALVADOR, Edgard. Química Essencial. São Paulo. Ed. Saraiva.

. PERUZZO, Tito Miragaia e CANTO, Eduardo Leite. Química: Na Abordagem do Cotidiano. São Paulo. Ed. Moderna.

- COSTA, Maria Claudia e SANTOS, Gilson Oliveira. Química: A Visão do Presente. Belo Horizonte. Ed. Lê.

- Apostila POSITIVO

OBSERVAÇÃO: Serão consultados sites de Jornais e livros do acervo da biblioteca

São Paulo, Março de 2.006

O plano de curso de 2005 foi organizado da forma comumente pedida na maioria das escolas (objetivos gerais, conteúdo por série, metodologia e avaliação). Complementando esse plano, os professores que o elaboraram se preocuparam em apontar os possíveis estudos do meio e projetos que poderiam acontecer durante o ano, porém sem detalhar como serão trabalhados, em que momento e com quais conteúdos estão relacionados. O plano é o mesmo tanto para o período diurno quanto para o noturno, como está indicado no início do documento.

Os professores se preocuparam ainda em indicar quais livros didáticos são as referências para o planejamento das aulas, atitude que a maioria dos docentes não pratica.

Após um ano de projeto LabVirt, dois dos três professores que elaboraram o plano de 2005, planejaram o de 2006 de forma praticamente idêntica ao do ano anterior. Além dos objetivos gerais detalham também os objetivos específicos para cada bimestre.

No início do documento aparece indicado que esse é para a $1^{\text {a }}$ série do Ensino Médio (que denominam ainda de colegial), mas os conteúdos das três séries são listados. Esses conteúdos permaneceram na mesma seqüência, mas alguns foram remanejados 
entre os bimestres, deixando claro que o plano é cópia do ano anterior e que não foi revisado pelos professores já que os objetivos específicos relacionam-se com o conteúdo da $1^{\mathrm{a}}$ série do EM e consta no plano o conteúdo das $2^{\mathrm{a}}$ e $3^{\mathrm{a}}$ séries.

Com isso, podemos concluir que, para este professor o que importa é ter a lista de conteúdos pré-determinada. $O$ documento não orienta o professor quanto aos objetivos a serem alcançados. Mesmo incoerente, está perfeito para ser anexado aos documentos oficiais da escola, já que para uma pessoa, a coordenadora pedagógica, por exemplo, que não conhece os conteúdos da disciplina é praticamente impossível perceber tais incoerências.

\section{Dados do questionário pós-projeto}

De acordo com o questionário aplicado ao final do projeto (Anexo 6), P1 conseguiu trabalhar com a proposta do LabVirt em sala de aula e para tanto elaborou seu plano de aulas que facilitou sua prática porque através dele é possível direcionar o trabalho.

P1 aponta ainda a dificuldade em executar o plano porque muitos alunos não haviam compreendido os conceitos, porém seguiu o plano exatamente como havia planejado, sem problemas.

Esse professor coloca que o trabalho com o Projeto LabVirt em sala de aula interferiu no seu plano anual na medida em que os alunos perderam o ritmo da aprendizagem sendo necessário trabalhar alguns conceitos com mais profundidade.

\section{E. Discussão dos dados}

Analisando e comparando todos os dados apresentados acima, percebemos concordâncias e divergências em relação ao discurso e a prática de $\mathrm{P} 1$, apontadas a seguir.

P1 considera necessário para planejar, fazer uma avaliação diagnóstica no início do ano com o intuito de conhecer o que o aluno já viu. Mas, analisando os planos de curso de anos diferentes, que são praticamente iguais, não podemos acreditar que as turmas sejam tão semelhantes a ponto de não haver necessidade de fazer alterações.

Os planos de curso são, realmente, conseqüência de um planejamento baseado em conteúdos, pois os outros itens nos parecem que estão presentes apenas para cumprir as normas estabelecidas pela instituição, visto que não se relacionam e não subsidiam o professor em seu trabalho. Deste modo, esses documentos cumprem 0 papel de roteiro orientador como é esperado por P1.

Quanto aos conteúdos a serem ensinados, ao mesmo tempo em que P1 diz basear-se nos vestibulares e no que é ensinado em outros colégios, ele mantém ou 
exclui alguns dos conteúdos se não sentir segurança em ensiná-los ou se perceber que o tempo não será suficiente.

\subsubsection{Professor $P 2$}

A. Dados sobre a concepção de planejamento

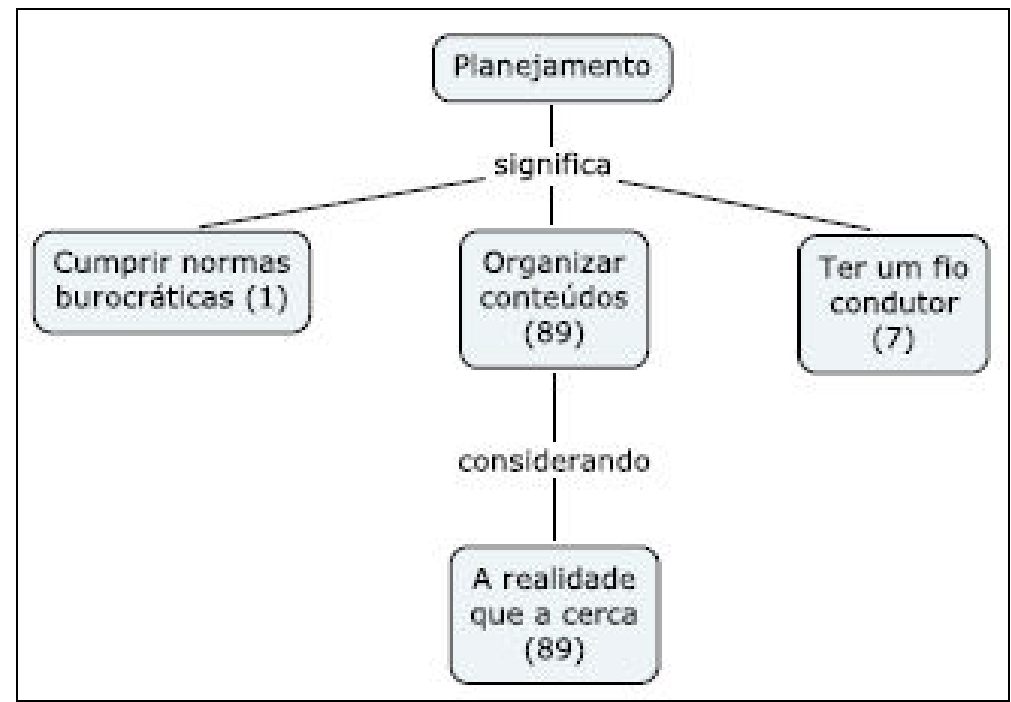

MC9. Planejamento_significado e finalidade de P2

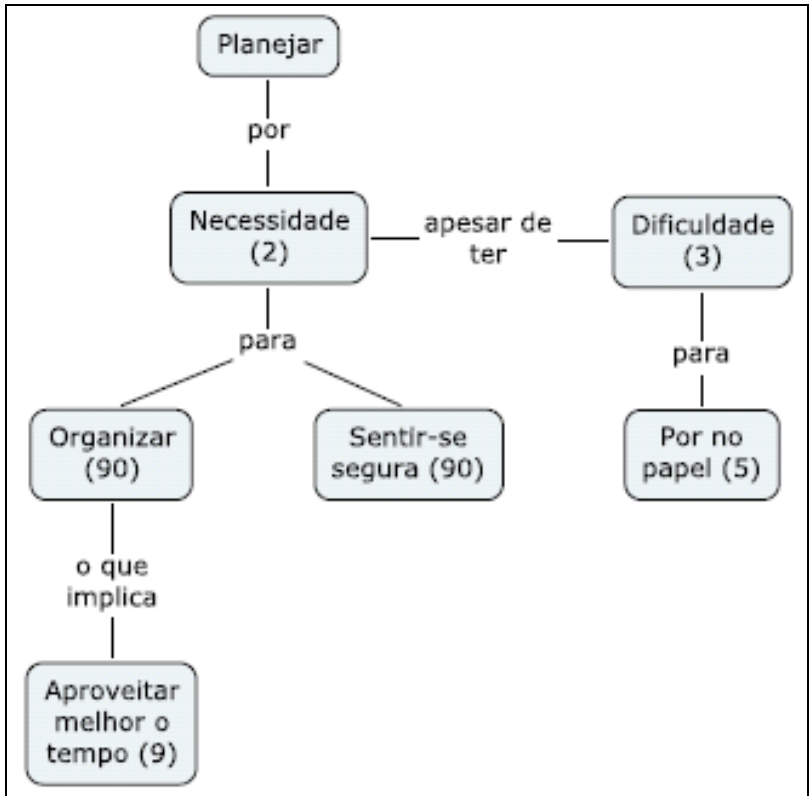

MC10. Planejamento_importância de P2 


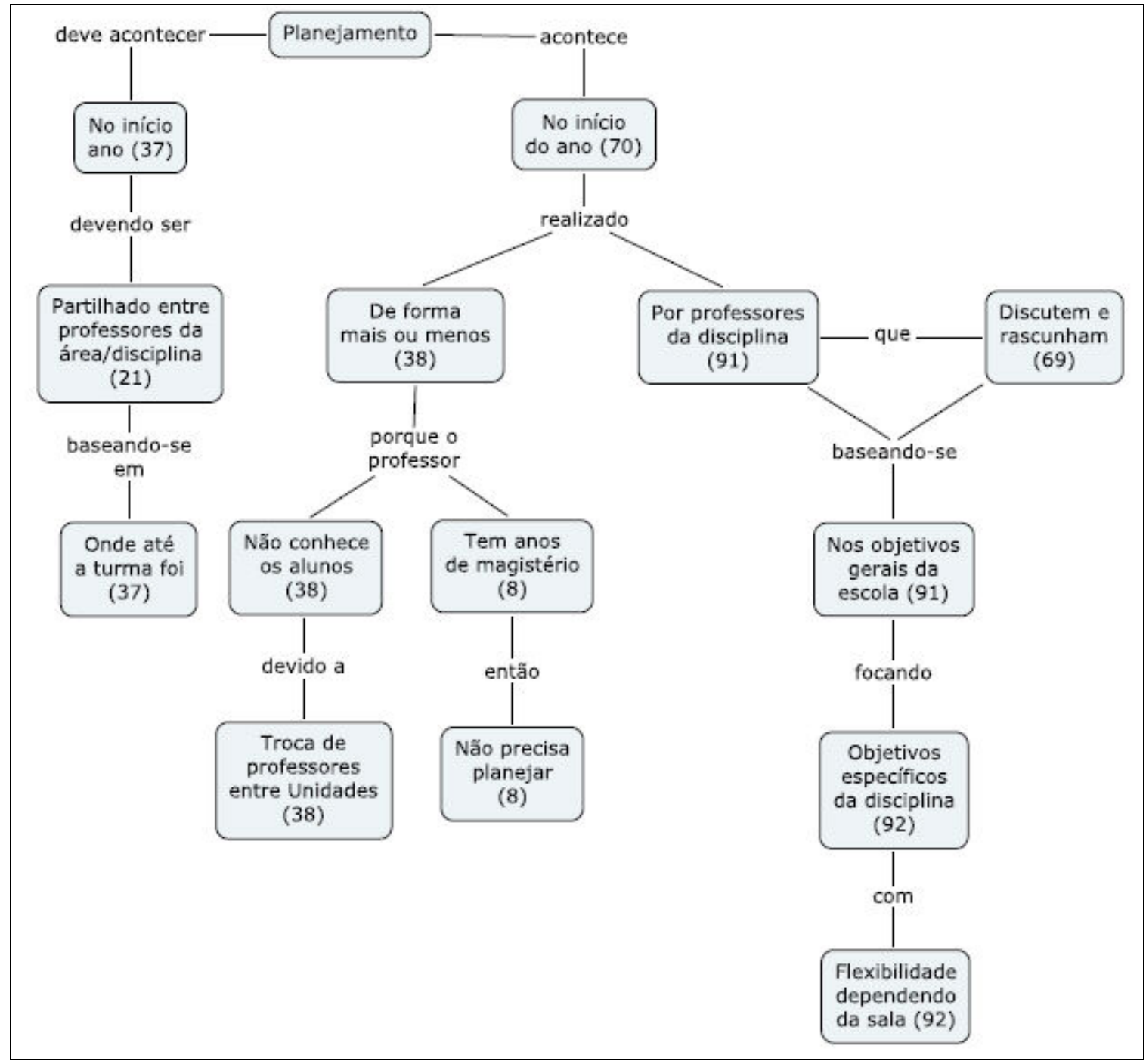

MC11. Planejamento_processo de P2

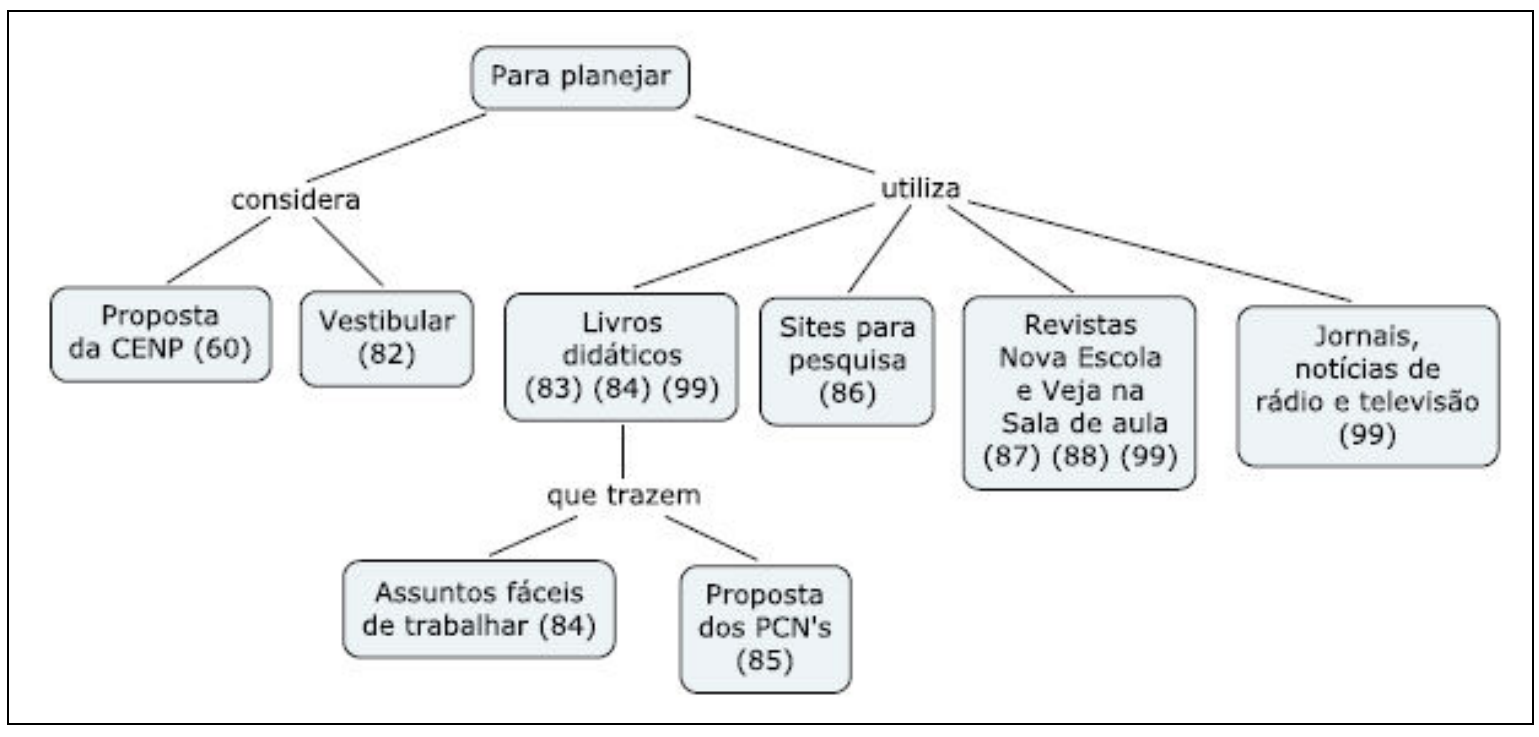

MC12. Planejamento_referências bibliográficas de P2 
O professor P2 percebe o planejamento com mais de uma finalidade, porém a maior ênfase está no fato de que o elabora para cumprir normas burocráticas, apesar de entender que é uma necessidade para sua prática. Quando menciona que ...não sou uma pessoa organizada, principalmente na questão do tempo, entendemos que o planejamento ajuda a organizar seu trabalho em relação ao tempo dedicado para cada conteúdo a ser ensinado permitindo então que não se perca ao longo do ano e cumpra o conteúdo planejado no início.

Apesar de dizer que seu planejamento se baseia nos objetivos gerais da escola, declara que gostaria que o planejamento fosse baseado em até onde a turma foi, deixando claro que para ele o planejamento consiste da seleção e organização de conteúdos, pois seu ponto de partida está em o quê os alunos já aprenderam e o quê está faltando.

Seu planejamento acontece no início do ano juntamente com professores da mesma disciplina, possibilitando a troca de experiências e idéias. Esse procedimento para esse professor é indispensável porque ele possui uma dificuldade para planejar seu trabalho e colocar no papel. Utiliza muitos materiais para trabalhar, mas considera o conteúdo do vestibular e a proposta da CENP os eixos estruturadores de seu trabalho. Os livros didáticos são referências para organizar suas aulas desde que sejam atualizados e tragam assuntos mais fáceis de trabalhar. 


\section{B. Dados sobre a elaboração do plano de curso}

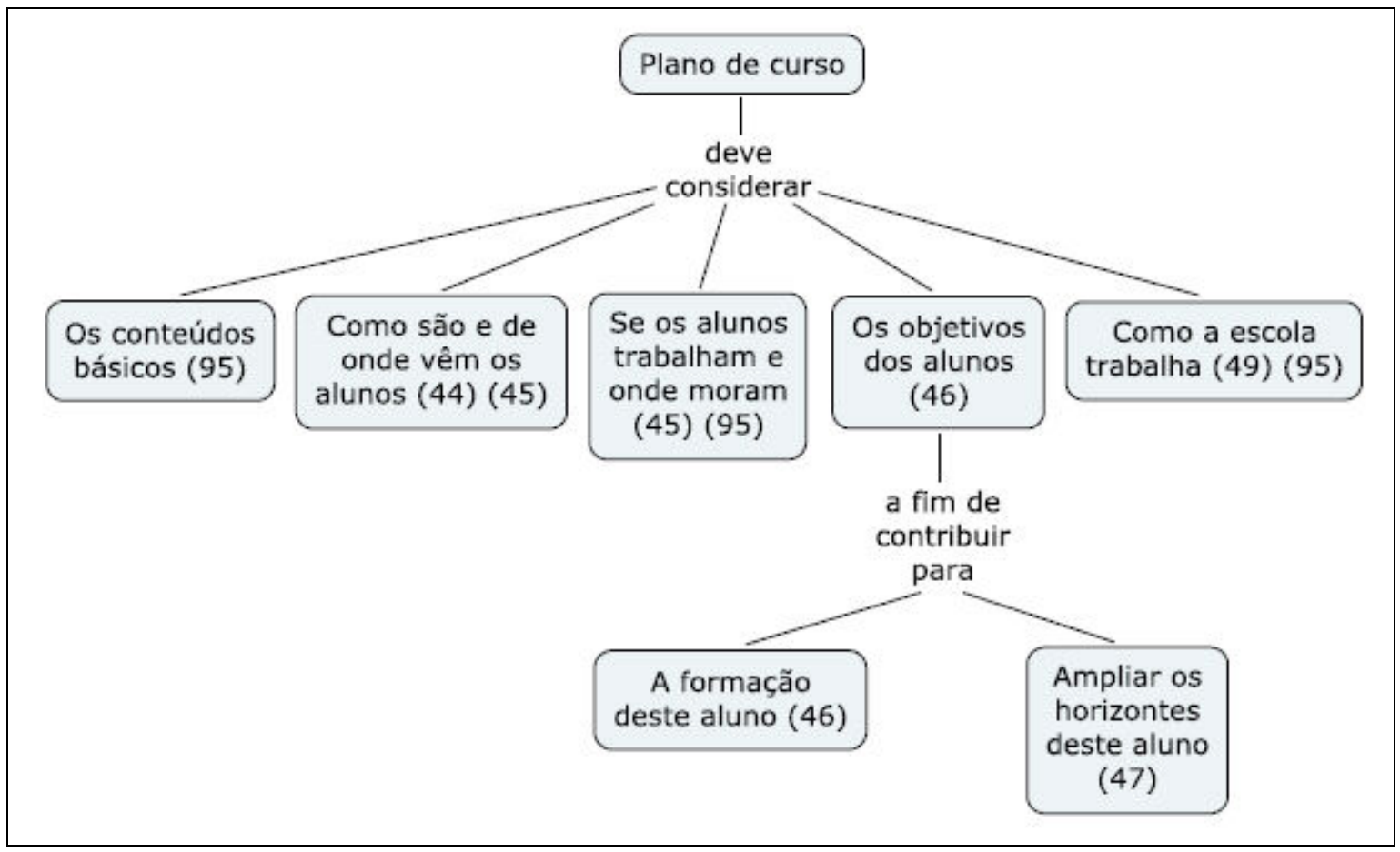

MC13. Plano de curso_pré-requisitos de P2

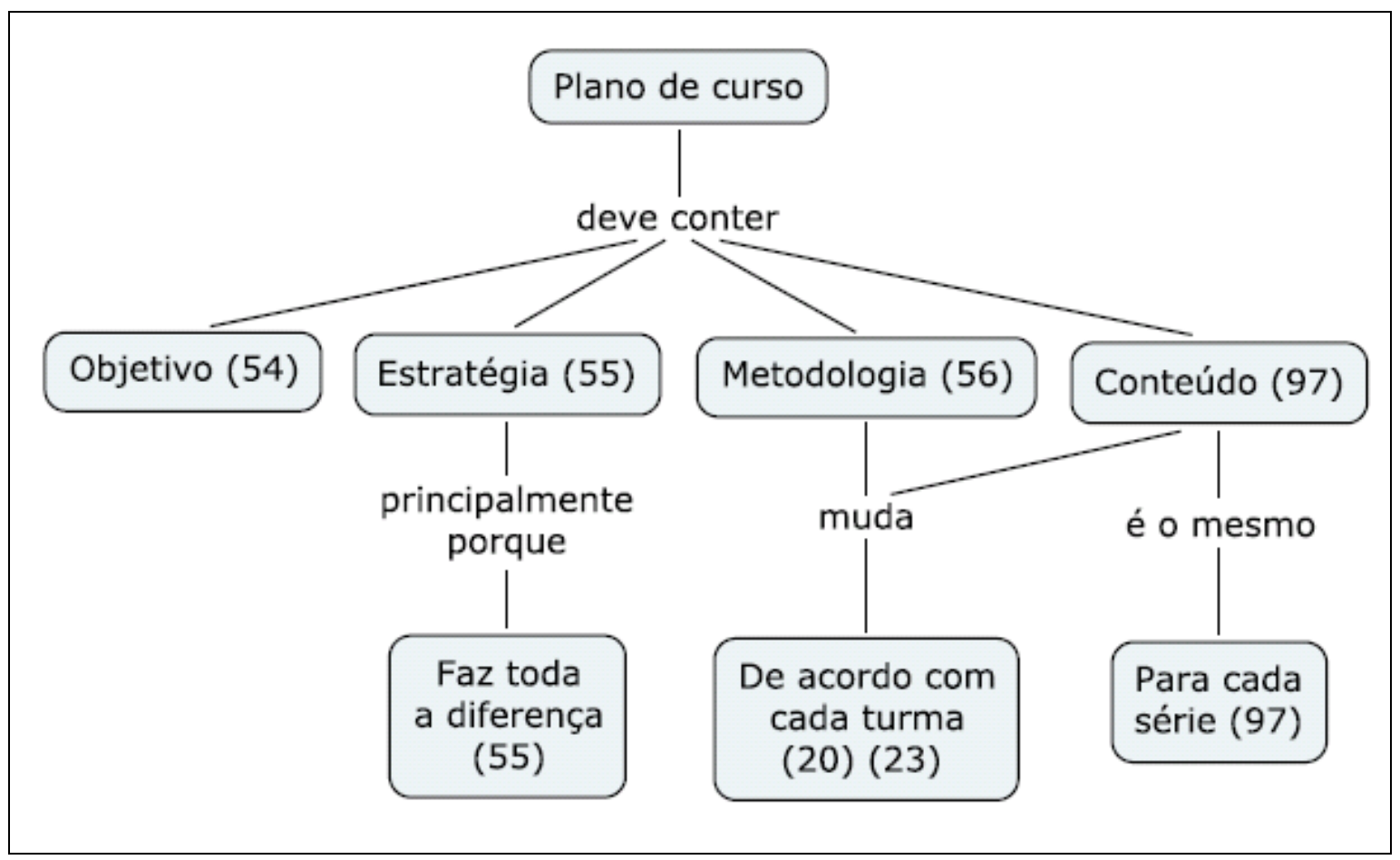

MC14. Plano de curso_características de P2 


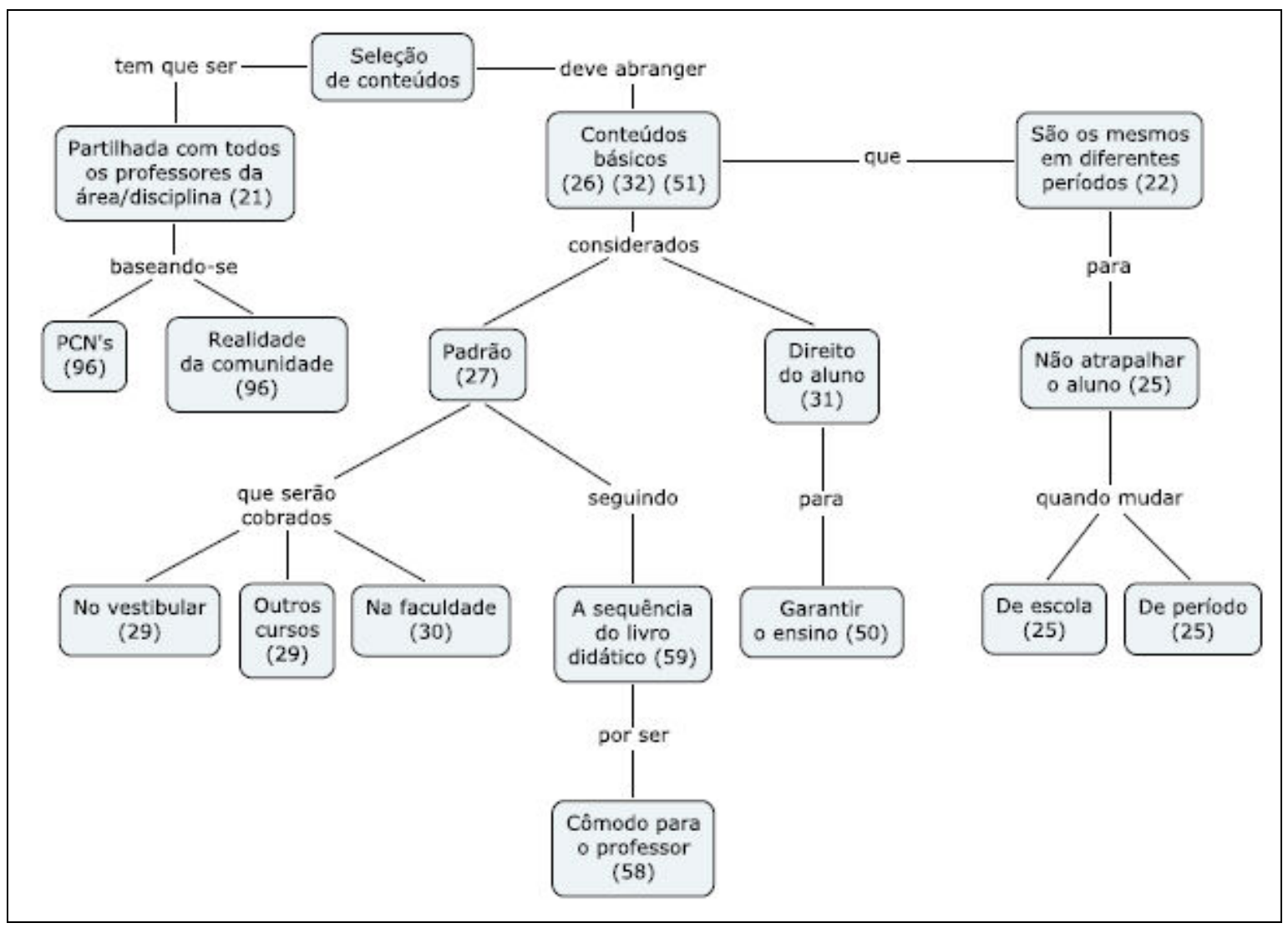

MC15. Plano de curso_seleção de conteúdos de P2 


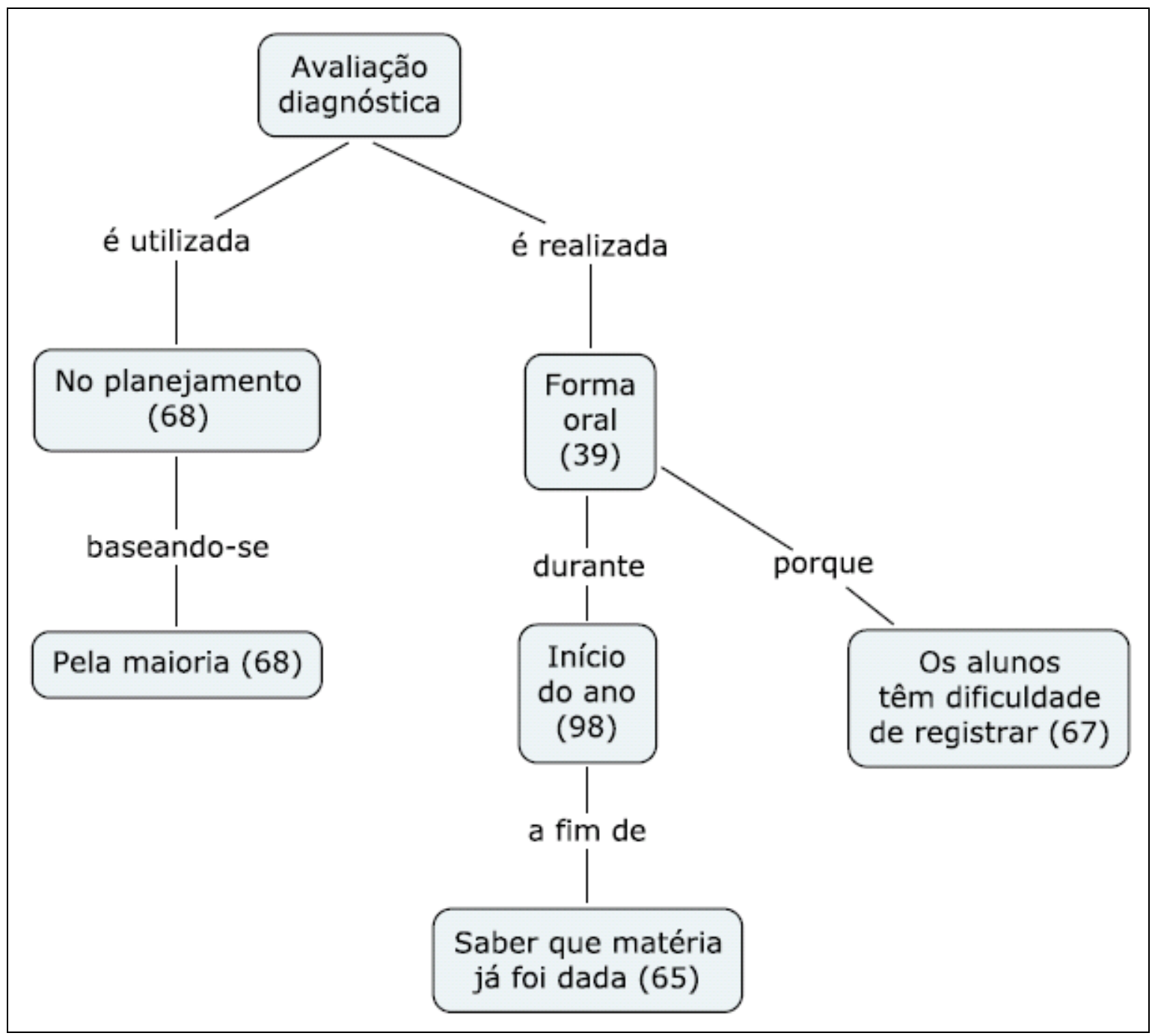

MC16. Plano de curso_avaliação diagnóstica de P2

O plano de curso de P2 é elaborado considerando muitos dados da clientela da escola, inclusive seus objetivos de vida e rotinas, para tentar atender ao máximo todas as necessidades destes alunos. Porém os conteúdos básicos, que entendemos ser os que constam nos livros didáticos, não são ignorados.

Pensa que o plano deve estar estruturado em objetivos, estratégia e conteúdo que são os mesmos para todas as turmas de uma mesma série. E ainda a metodologia, que vai mudar de acordo com a realidade de cada turma. Entretanto, não deixa explícito de que forma essa mudança ocorreria e por quais motivos.

Os conteúdos são os básicos para cada série e iguais em diferentes períodos, garantindo assim o direito do aluno aprender e a possibilidade de ser remanejado de turma ou mudar de escola sem prejudicar seu aprendizado. São baseados não só nos PCNs mas também no vestibular, em outros cursos e na faculdade pois ...dependendo da matéria que ele optar, ele vai ter que ter aquele mínimo... Sua seqüência é padrão de livros didáticos até por uma comodidade do professor. 
Para que possa selecionar os conteúdos necessita saber que matéria já foi dada à turma e para isso realiza a avaliação diagnóstica que consiste em identificar oralmente quais conteúdos já foram estudados pela maioria servindo como parâmetro para o planejamento.

\section{Os planos de curso pré e pós-projeto}

Os planos de curso de P2 são os mesmos de P1 pois, esses professores trabalham na mesma escola e elaboram juntos os planos de curso que valem para todos os períodos. Sendo assim, a análise dos planos é a mesma de P1.

\section{Dados do questionário pós-projeto}

P2 conseguiu trabalhar com o Projeto LabVirt em sala de aula o que exigiu a elaboração do plano de aulas. Para isso sentiu muita dificuldade, principalmente no que diz respeito à organização desse plano.

O professor percebeu que o fato de ter elaborado o plano de aulas facilitou muito seu trabalho com o projeto pois otimizou o tempo necessário para as atividades. Seguiu o plano exatamente como havia pensado não necessitando realizar alterações ao longo do processo. Enfim, percebeu a importância de tê-lo já que organizou melhor a sua prática.

\section{E. Discussão dos dados}

O professor P2 concebe que o plano de curso é feito para cumprir uma exigência da escola, mas não excluiu a necessidade de tê-lo em mãos para organizar seu trabalho.

Comparando os planos apresentados percebemos que ambos são praticamente idênticos e, portanto, não sofreram alterações de um ano para o outro. As pequenas mudanças não são significativas, o que contraria a idéia de que a realidade da clientela é considerada no momento do planejamento. Isto também se evidencia na metodologia que é a mesma para todas as séries e nos dois anos planejados.

A reorganização de conteúdos nos planos, que foi a única alteração feita, enfatiza a idéia de que o plano serve para organizar conteúdos e que os outros itens só estão detalhados para seguir o modelo padrão proposto pela escola. Essa organização baseiase na seqüência apresentada nos livros didáticos e sua seleção na comodidade do professor.

Quando menciona que a gente acha que já deu aula dez anos então não preciso mais planejar, deixa clara sua concepção simplista sobre educação de que para saber ensinar basta conhecer os conteúdos da disciplina e adquirir um pouco de experiência. 


\subsubsection{Professor P3}

A. Dados sobre a concepção de planejamento

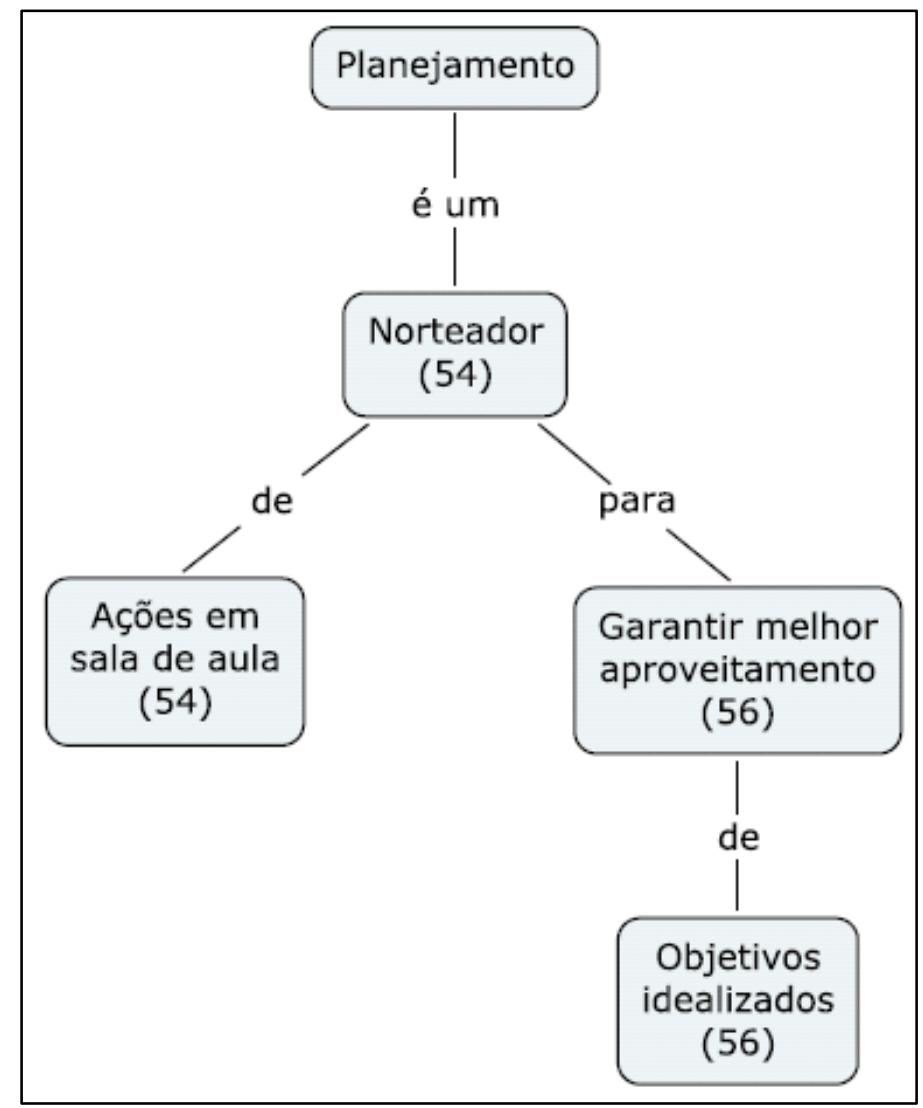

MC17. Planejamento_significado e finalidade de P3 


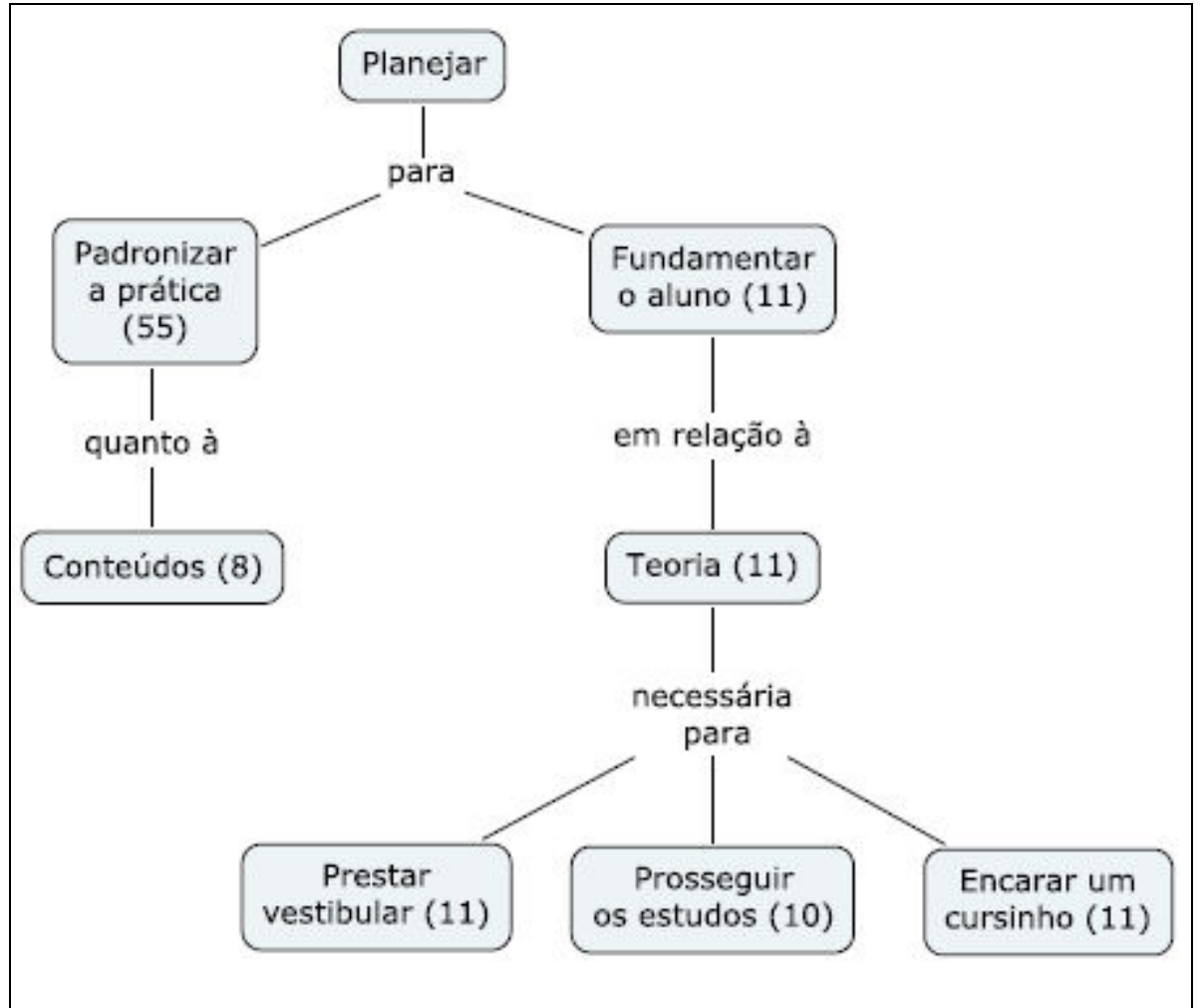

MC18. Planejamento_importância de P3

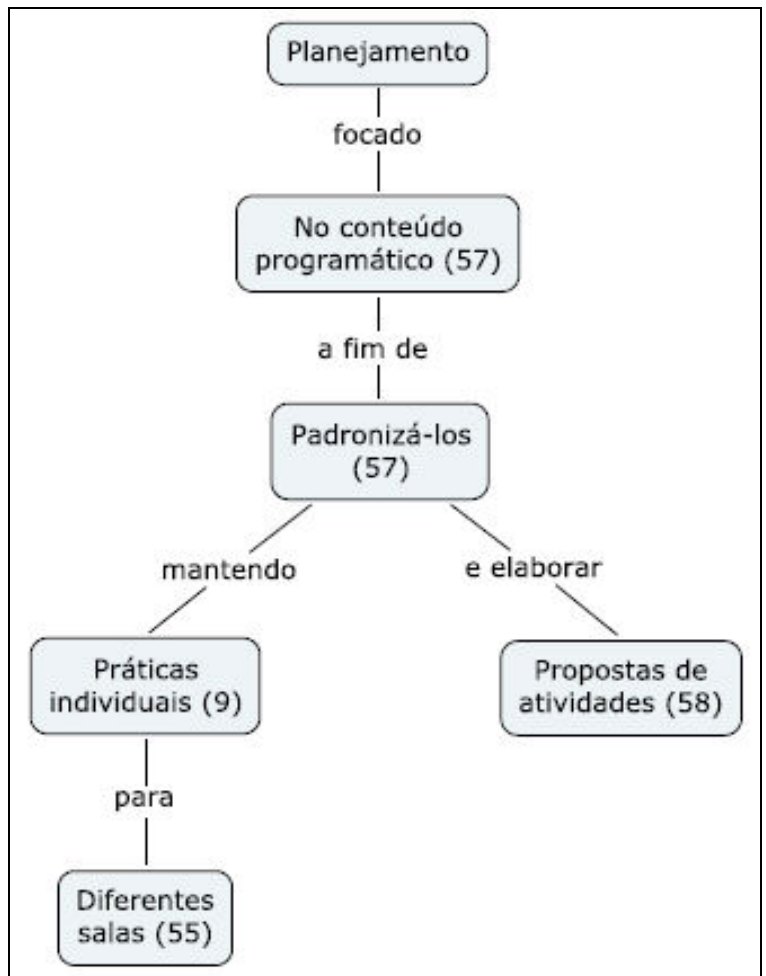

MC19. Planejamento_processo de P3 


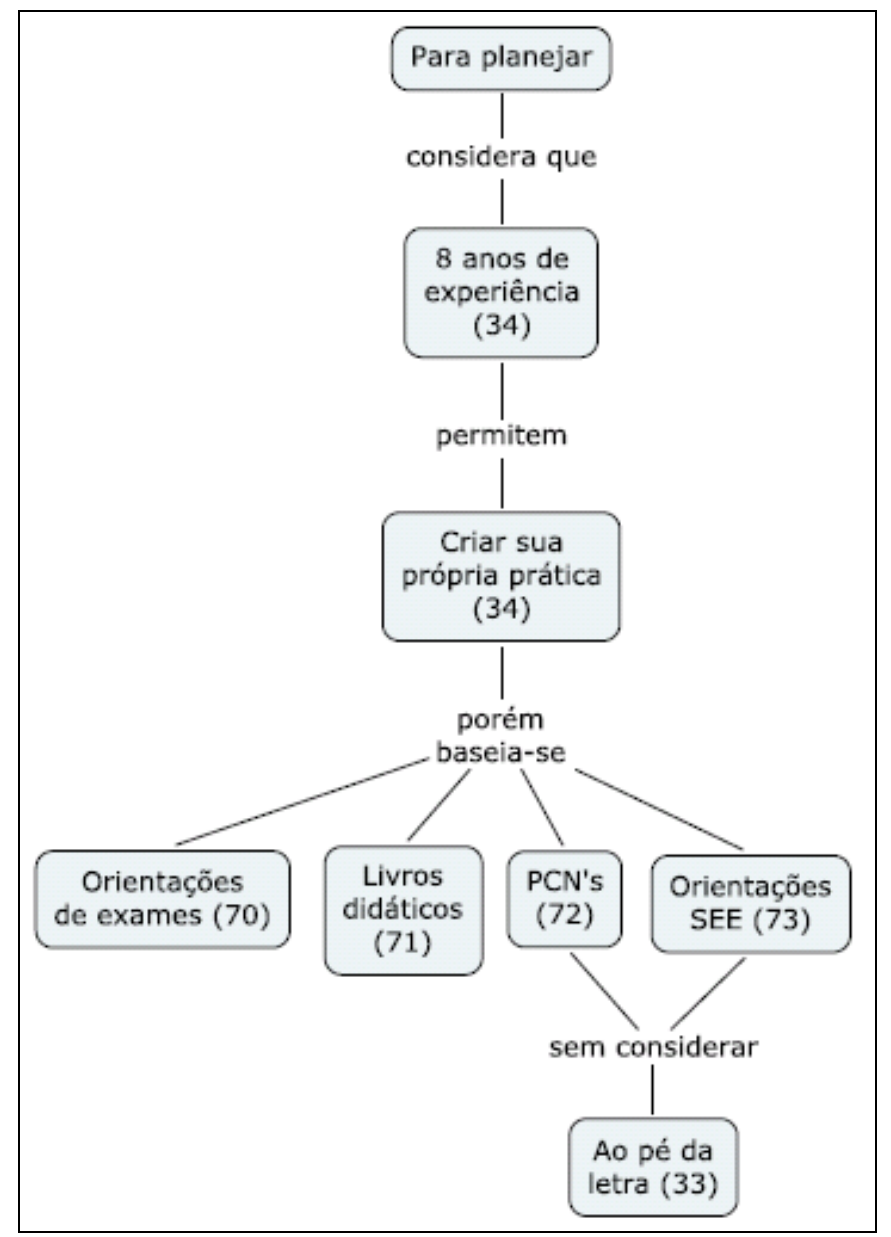

MC20. Planejamento_referências bibliográficas de P3

Segundo esse professor, o planejamento também é um norteador de suas ações. Com ele o aproveitamento dos objetivos idealizados é melhor. É uma maneira de padronizar a prática dos professores em relação aos conteúdos a serem ensinados. ...a gente tinha um sério problema, apesar de estar tudo documentado, dos professores de manhã e de noite trabalharem diferente.

Portanto, o planejamento é focado no conteúdo programático buscando padronizá-los em toda a escola para então elaborar propostas de atividades. Desta forma, os alunos se fundamentam de maneira uniforme, na teoria necessária para a continuidade de seus estudos e para os exames pré-vestibulares. A realidade e necessidades de cada turma são atendidas nas estratégias do professor, porque a prática é individual de cada um.

O tempo de trabalho permite que a gente vá criando uma prática própria, vá adaptando, tirando aquilo que não deu certo, colocando coisas novas... Mas para os conteúdos, são os exames oficiais, os livros didáticos, os PCN's e a proposta da CENP que auxiliam o professor na hora do planejamento. 


\section{B. Dados sobre a elaboração do plano de curso}

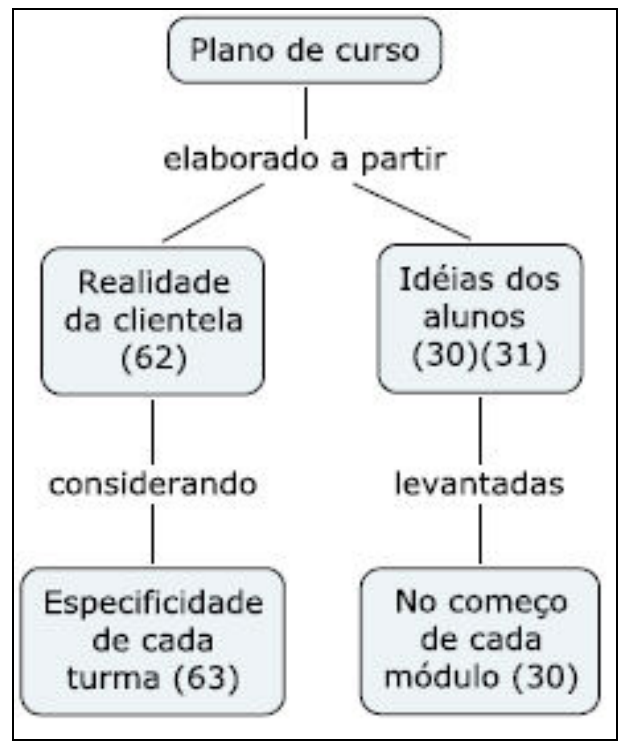

MC21. Planejamento_pré-requisitos de P3

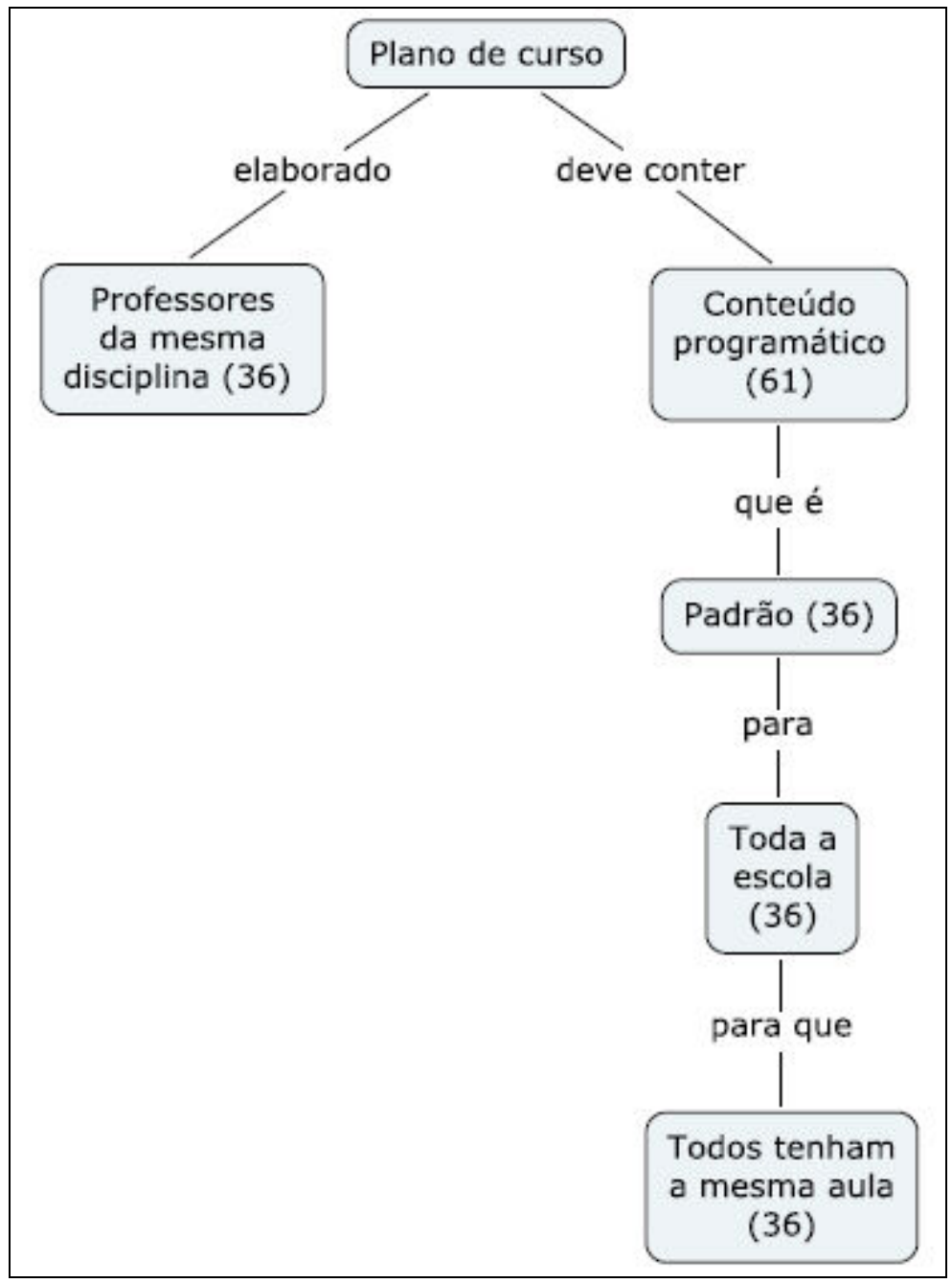

MC22. Planejamento_características de P3 


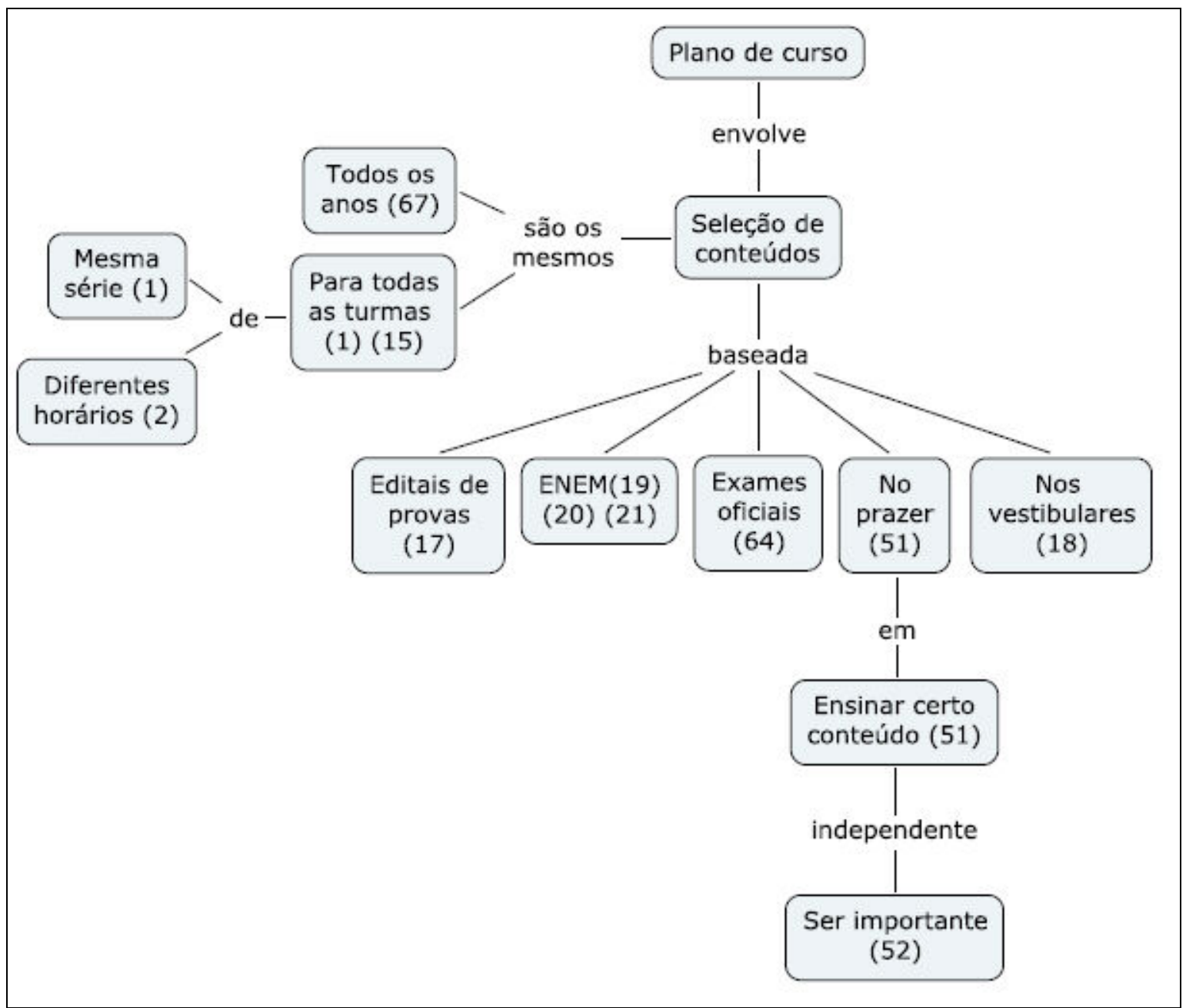

MC23. Planejamento_seleção de conteúdos de P3 


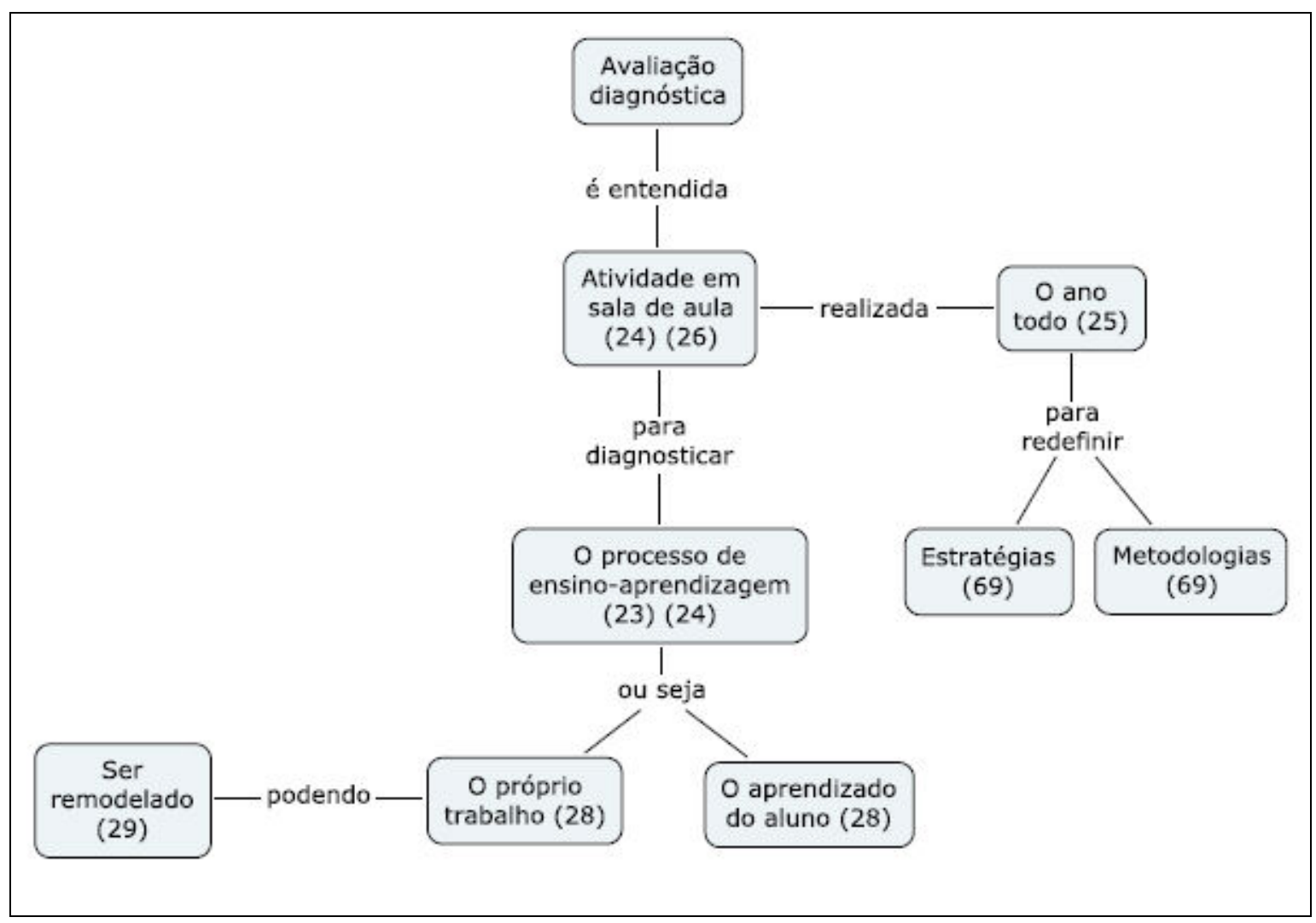

MC24. Plano de curso_avaliação diagnóstica de P3

Quando P3 elabora seu plano diz que considera a realidade da clientela e as idéias que os alunos já trazem, respeitando assim a especificidade de cada turma. $O$ plano é elaborado pelos professores da mesma disciplina e deve conter o conteúdo programático.

A escolha desses conteúdos está baseada em orientações bem diversas, como vestibulares e ENEM. O prazer do professor também é considerado, independente da importância em aprender alguns conceitos, é um conteúdo que ao meu ver não tenho muito prazer de trabalhar com o aluno não, ... é um conteúdo que eu deixaria de lado por opção própria.

Uma avaliação diagnóstica acontece no início do ano para identificar as idéias dos alunos sobre algum conceito. Na primeira aula eu peço pra eles trazerem a idéia do que eles sabem. Este diagnóstico é utilizado no momento do planejamento e dependendo do resultado é preciso parar e voltar, refazer. Ao longo do ano, a avaliação diagnóstica é utilizada como uma forma de identificar problemas no processo de ensino-aprendizagem. Pode ser atividade, prova ou alguma coisa que eu faça em sala de aula para medir quão suficiente está sendo esse processo de ensino-aprendizagem. Isto permite reorganizá-lo principalmente quanto às estratégias e metodologias. 


\section{Os planos de curso pré e pós-projeto}

\section{Planejamento Anual - Química - 2004 \\ $1^{\mathrm{a}}, 2^{\mathrm{a}}$ e $3^{\mathrm{a}}$ Séries do Ensino Médio}

\section{"Interação e Transformação"}

Profs. P2 e P3

\section{Objetivos Gerais}

Dar ao educando a possibilidade de desenvolver e compreender os conceitos e relacioná-los entre si, partindo do seu ambiente social, não esquecendo dos aspectos históricos, sociais, políticos e econômicos que norteiam esses conceitos.

Dentro desses aspectos, desenvolver a capacidade de abstração e comparação a partir de um universo macroscópico a fim de promover a integração entre todos os segmentos da Ciência.

\section{Objetivos Específicos}

Nortear o tema "Integração e Transformação", fazendo com que o aluno, como ser humano, veja que está em constante transformação, resultado de Interação entre os fatores biológicos e ambientais.

O processo de aprendizagem deve ser caracterizado por contínua construção de conhecimento, a partir de experiências vivenciadas. Desta forma o professor, o material de instrução e o ambiente atuam como facilitadores da elaboração e reconstrução do conhecimento.

\section{Tratamento Metodológico}

A metodologia será dinâmica - dialógica, baseada nos diálogos que se estabelecem entre o aluno e o professor, outros alunos e com o próprio texto.

O aluno deve colocar a sua visão em relação aos assuntos e temas ligados à sua realidade, cabendo ao professor facilitar e proporcionar e, a partir disso, modificar e ampliar a visão de mundo do aluno, tornando-o mais criativo e compromissado. 


\section{Procedimento Metodológico}

Diversificação das aulas, de modo a torná-las mais interessantes utilizando diversos recursos, do tipo: audiovisuais, laboratório, excursões, utilização de materiais extraclasse (jornais, revistas, paradidáticos, etc).

Retomada de conteúdo (pequenas revisões de técnica de operação para atingir os objetivos das aulas).

Reuniões periódicas que reforçam a integração entre professores da disciplina e das outras disciplinas afins.

Aulas práticas com uso de experimentação, jogos pedagógicos, etc.

\section{Processos de Avaliação e recuperação}

\section{- Avaliação}

A avaliação deve ser contínua e levar em consideração o processo de aprendizagem e não somente o produto final. $O$ aluno deverá ser avaliado segundo critérios que levem em conta o seu desenvolvimento global, individual e em relação ao grupo.

- Recuperação

A recuperação será um processo contínuo e/ou paralelo, dando-se sempre que necessário ao aluno, a oportunidade de rever-se no processo de construção do conhecimento.

\section{Conteúdos Programáticos da Disciplina}

- $1^{\text {a }}$ Série do Ens. Médio

\begin{tabular}{|c|c|c|c|}
\hline $\begin{array}{c}1^{\circ} \\
\text { BIMESTRE }\end{array}$ & $\begin{array}{c}2^{\circ} \\
\text { BIMESTRE }\end{array}$ & $\begin{array}{c}3^{\circ} \\
\text { BIMESTRE }\end{array}$ & $\begin{array}{c}4^{\circ} \\
\text { BIMESTRE }\end{array}$ \\
\hline $\begin{array}{l}\text { - Histórico } \\
\text { - Propriedades da } \\
\text { Matéria } \\
\text { - Estrutura } \\
\text { Atômica }\end{array}$ & $\begin{array}{l}\text { - Estudo da } \\
\text { Tabela } \\
\text { Periódica } \\
\text { - Ligações } \\
\text { Químicas } \\
\text { entre átomos }\end{array}$ & $\begin{array}{l}\text { - Funções } \\
\text { Inorgânicas } \\
\text { - Estudo das } \\
\text { Reações } \\
\text { Químicas }\end{array}$ & $\begin{array}{l}\text { - Grandezas } \\
\text { Químicas } \\
\text { - Estequiometria. }\end{array}$ \\
\hline
\end{tabular}


- $\quad 2^{a}$ Série do Ens. Médio

\begin{tabular}{|c|c|c|c|}
\hline $\begin{array}{c}1^{\circ} \\
\text { BIMESTRE }\end{array}$ & $\begin{array}{c}2^{\circ} \\
\text { BIMESTRE }\end{array}$ & $\begin{array}{c}3^{\circ} \\
\text { BIMESTRE }\end{array}$ & $\begin{array}{c}4^{\circ} \\
\text { BIMESTRE }\end{array}$ \\
\hline $\begin{array}{l}\text { - Estudo das } \\
\text { Soluções } \\
\text { - Termoquímica }\end{array}$ & $\begin{array}{l}\text { - Cinética } \\
\text { Química } \\
\text { - Equilíbrio } \\
\text { Químico }\end{array}$ & $\begin{array}{l}\text { - Ionização } \\
\text { - Diluição } \\
\text { - } p H \text { e pOH } \\
\text { - Hidrólise } \\
\text { - Produto de } \\
\text { Solubilidade }\end{array}$ & $\begin{array}{l}\text { - Eletroquímica } \\
\text { - Eletrólise }\end{array}$ \\
\hline
\end{tabular}

- $\quad 3^{a}$ Série do Ens. Médio

\begin{tabular}{|l|l|l|l|}
\hline \multicolumn{1}{|c|}{$1^{\circ}$} & \multicolumn{1}{|c|}{$2^{\circ}$} & \multicolumn{1}{c|}{$3^{\circ}$} & \multicolumn{1}{c|}{$4^{\circ}$} \\
BIMESTRE & \multicolumn{1}{|c|}{ BIMESTRE } & \multicolumn{1}{|c|}{ BIMESTRE } & BIMESTRE \\
\hline $\begin{array}{l}\text { Q Histórico da } \\
\text { Química }\end{array}$ & $\bullet$ Isomeria & $\bullet$ Reações & $\bullet$ Revisão \\
Orgânica & Propriedades & Orgânicas & \\
- Cadeias & $\bullet$ Acidez & & \\
Carbônicas & Basicidade nos & & \\
- Funções & compostos & & \\
Orgânicas & orgânicos & & \\
\hline
\end{tabular}

\section{Plano Anual de 2005}

Componente Curricular: Química

Série: $1^{\mathrm{a}}$. $2^{\mathrm{a}}$ e $3^{\mathrm{a}}$ séries do Ensino Médio (MANHÃ E NOTURNO)

Professores: P1, P2 e P3

\section{OBJETIVOS GERAIS}

Objetivando-se que o ensino de Química não se resuma em uma simples 
transmissão de conteúdos, mas na aquisição, por parte do aluno, de conteúdos contextualizados, isto é, que tenham significação humana e social, propõe-se então, que se tome como ponto de partida a situação de interesse imediato do aluno, o que ele vive, conhece ou sofre influências e que se atinjam os conhecimentos químicos historicamente elaborados de modo que lhe permitam compreender e desenvolver uma consciência, mais plena de suas responsabilidades e direitos juntamente com o aprendizado disciplinar.

\section{CONTEÚDO}

\section{$1^{\circ}$ COLEGIAL}

. A História da Ciência e o ensino de Química

. O cotidiano no ensino de Química

. Química - Noções Fundamentais

. O átomo - Da História à sua Constituição

. Elementos Químicos - Classificação Periódica

. Ligações Químicas - Formação de Substâncias

. Reações Químicas - Transformações de Substâncias

. Funções Inorgânicas - Noções Fundamentais

\section{$2^{\circ}$ COLEGIAL}

. Reações Químicas

. Cálculos Químicos

. Funções Inorgânicas

. Físico- Química - Misturas Homogêneas e Heterogêneas

. Soluções

. Energia Térmica

. Cinética Química

\section{$3^{\circ}$ COLEGIAL}

. Gases - Estudo do Comportamento Físico

Cálculos Químicos . Química Orgânica

Carbono

Funções Orgânicas

Isomeria 


\author{
Diferenciação de Compostos Orgânicos \\ Produtos Orgânicos \\ Compostos Orgânicos - Fontes Naturais e Processos de Preparação \\ Importância Biológica e Importância Industrial
}

\title{
III - METODOLOGIA
}

. Aulas expositivas

. Resolução de exercícios individuais e em grupo

. Debates

. Pesquisas

. Experimentos em sala de aula, sala de vídeo, sala de informática

. Excursões

. Seminários

. Textos de jornais e revistas

IV - AVALIAÇÃO

. Avaliação contínua

. Resolução de exercícios individuais e em grupo

. Trabalhos individuais e em grupo

. Relatórios

. Seminários

. Assiduidade

. Pontualidade

. Participação e interesse em todas as atividades desenvolvidas em sala de aula . Avaliação individual / dupla

\section{V - ESTUDOS DO MEIO}

. Exposições e Eventos ligados ao conteúdo.

. Exposições e Eventos ligados aos temas transversais.

. Parques Temáticos

. Visitas às Empresas e /ou Indústrias Químicas relacionadas ao conteúdo.

\section{VI - PROJETOS}

. Labvirt 


\section{. Feira de Ciências}

\section{VII - BIBLIOGRAFIA BÁSICA}

. USBERCO, João e SALVADOR, Edgard. Química Essencial. São Paulo. Ed. Saraiva.

. PERUZZO, Tito Miragaia e CANTO, Eduardo Leite. Química: Na Abordagem do Cotidiano. São Paulo. Ed. Moderna.

. COSTA, Maria Claudia e SANTOS, Gilson Oliveira. Química: A Visão do Presente. Belo Horizonte. Ed. Lê.

- Apostila POSITIVO

OBSERVAÇÃO: Serão consultados sites de Jornais e livros do acervo da biblioteca

São Paulo, Maio de 2.005

O plano de curso de 2004 para as três séries do Ensino Médio foi elaborado por P2 e P3 e está dividido em objetivos gerais e específicos, metodologia, avaliação e conteúdo programático. Sua configuração é da forma padrão sem muitos detalhes dos procedimentos de cada tópico. Os conteúdos estão organizados seguindo a proposta de livros didáticos tradicionais. Os professores não indicam os livros que são utilizados como referência para o trabalho.

O plano de 2005 foi elaborado por P1, P2 e P3 e contempla, além dos tópicos do plano anterior, os possíveis estudos do meio, os projetos e as referências bibliográficas. Houve uma reorganização dos conteúdos, mas ainda mantém a seqüência dos livros didáticos que foram citados na bibliografia básica. Nesse plano, os tópicos estão mais detalhados permitindo que o leitor possa saber quais serão os meios para ensinar e os instrumentos utilizados para avaliar.

Em ambos os casos, somente os conteúdos são diferentes para cada série. Isso nos revela que ao pensar no plano de curso o foco do professor está no conteúdo e os outros itens são elaborados mecanicamente, sem reflexões. Não é possível, por exemplo, que em todas as séries do Ensino Médio, os objetivos de ensinar Química sejam os mesmos.

\section{Dados do questionário pós-projeto}


Durante o ano de 2005 esse professor foi aprovado em um Programa de Mestrado em Portugal e por isso não chegou ao fim do projeto. Não pudemos aplicar o questionário para obtermos informações sobre sua participação. Porém, como acompanhamos esse professor um bom período, podemos dizer que ele trabalhou com o LabVirt em sala de aula de uma forma bem tranqüila. Para isso, elaborou um plano na forma de portfólio que entregou para cada aluno, assim eles podiam se organizar melhor para as aulas.

\section{E. Discussão dos dados}

P3 além de professor é coordenador pedagógico da escola no período noturno. Talvez por isso sua visão sobre educação seja diferente da dos demais. Ele consegue perceber a importância de organizar seu trabalho através do planejamento e para isso planeja suas aulas diariamente, apesar de não registrar.

Mesmo assim, analisando seus planos, percebemos que sua prática no planejamento não difere da dos outros, porque a organização do trabalho na forma do plano é muito semelhante a todos os outros planos que já analisamos. Esse não reflete a prática do professor em sala de aula e muito menos o que esse pensa sobre o ensino de Química.

Confirmando que o plano para esse professor é um mero documento administrativo, temos os objetivos, metodologia e avaliação, idênticos para todas as séries. Se para o professor o plano fosse uma necessidade para organizar e nortear seu trabalho como um todo, teríamos um plano para cada série e mais ainda, um plano para cada turma, com objetivos específicos diferentes, pois entendemos que cada uma tem suas particularidades que o professor identifica nas atividades ao longo do ano. Isso se concretiza nos portfólios que o professor prepara para cada sala ...cada módulo segue descrito separadamente mais especificamente e personalizado à sala. 


\subsubsection{Professor P4}

\section{A. Dados sobre a concepção de planejamento}

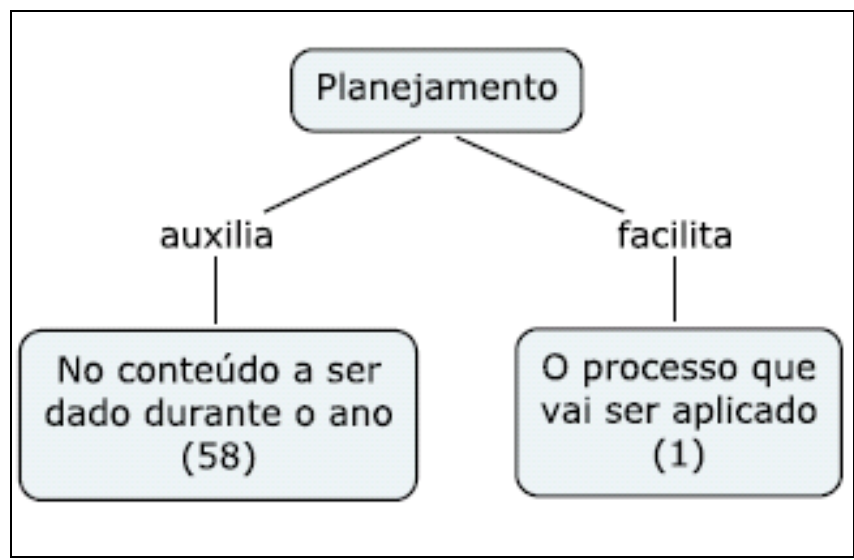

MC25. Planejamento_significado e finalidade de P4

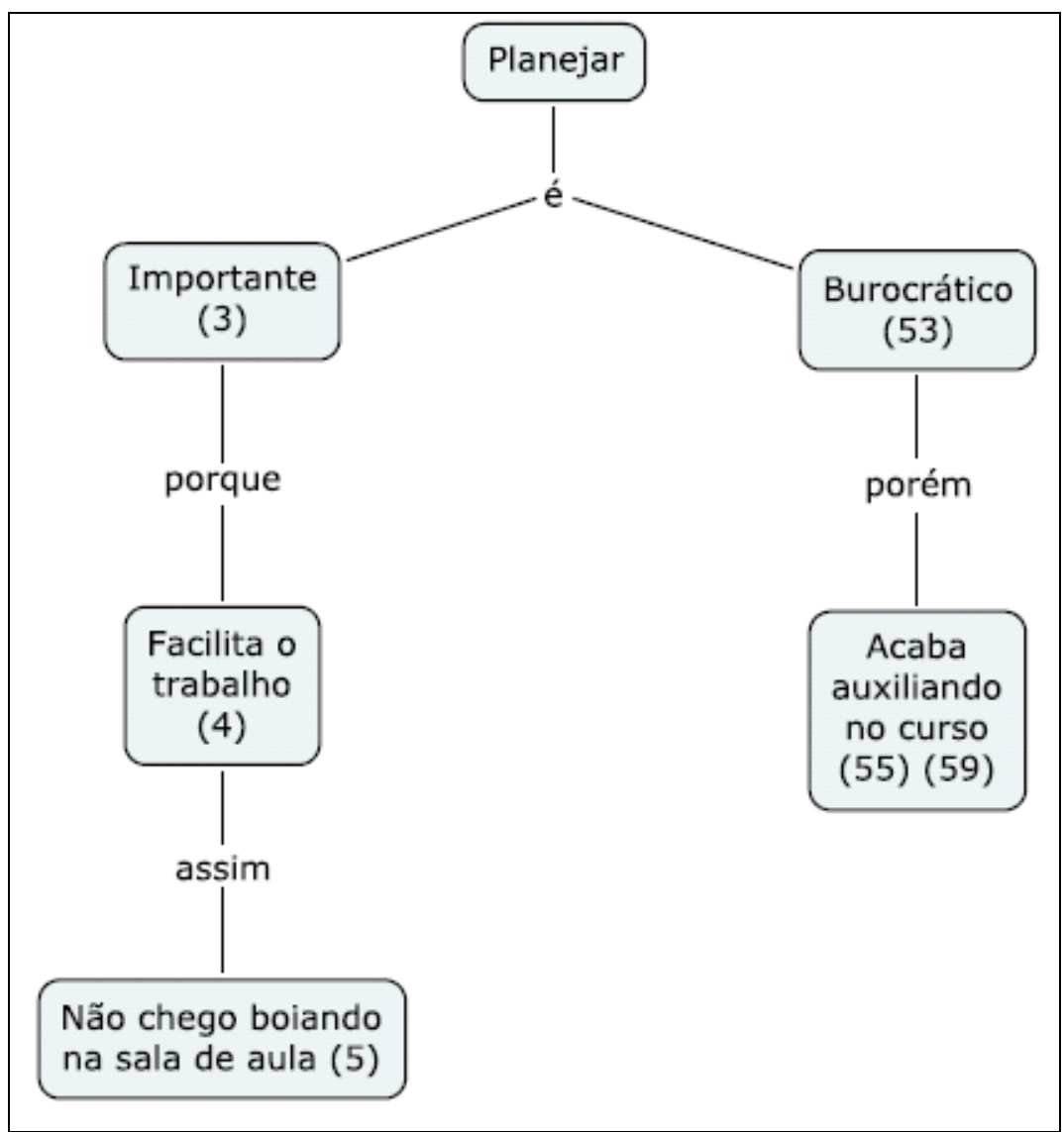

MC26. Planejamento_importância de P4 


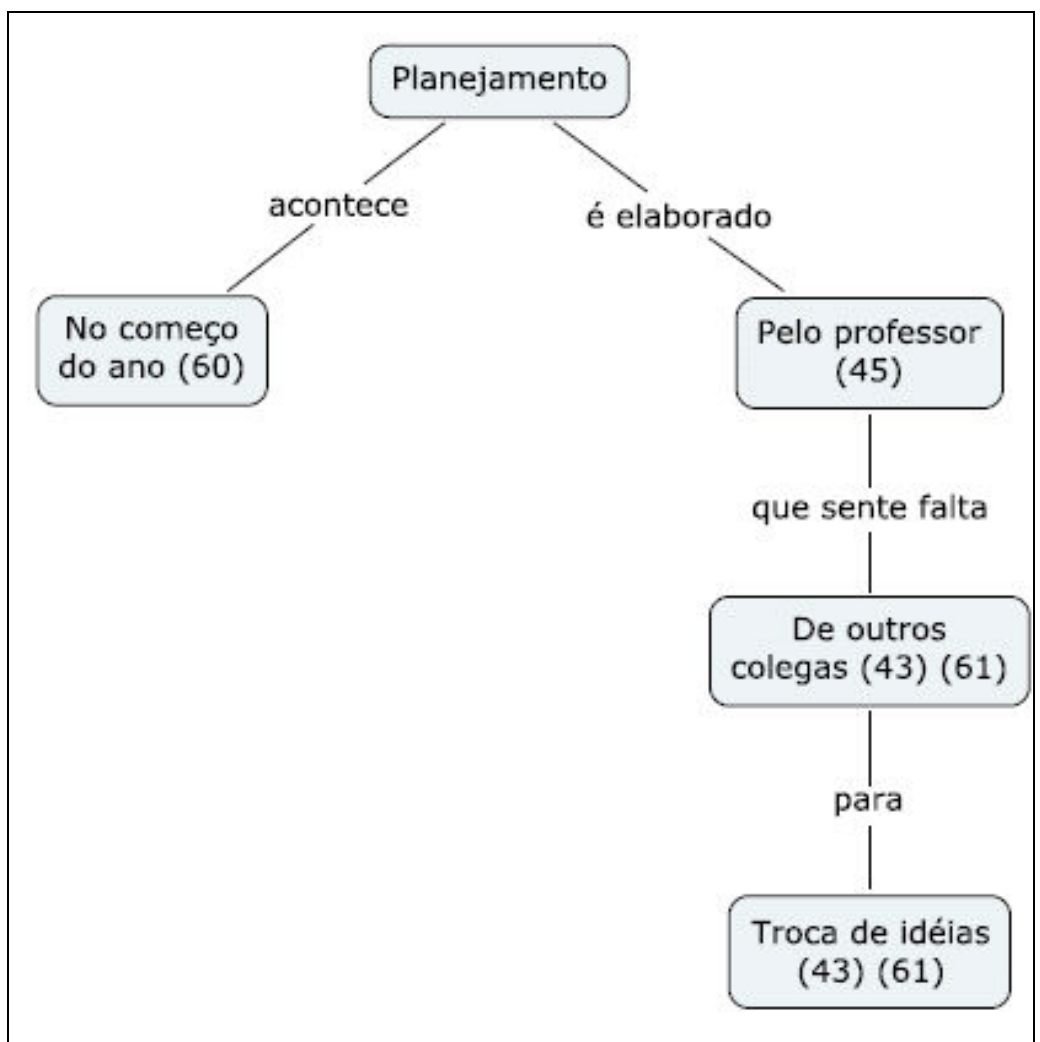

MC27. Planejamento_processo de P4

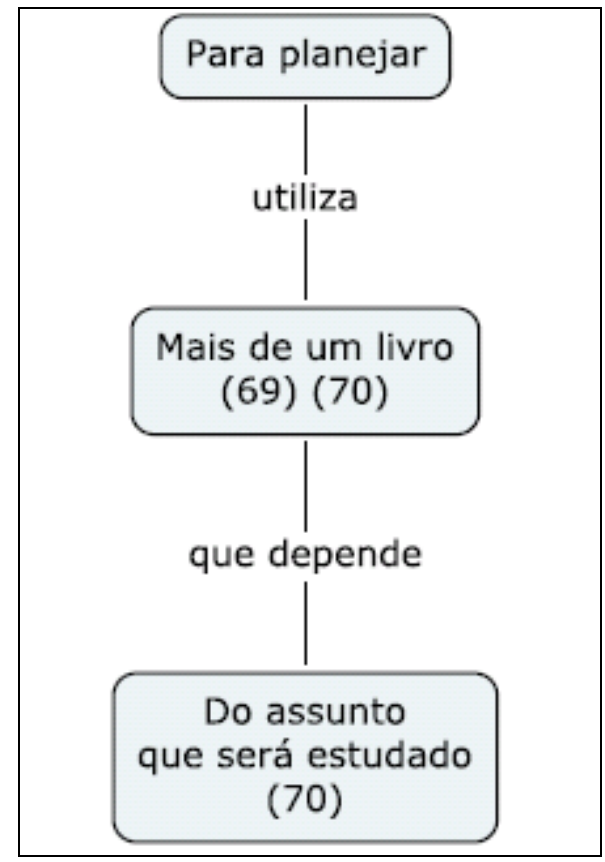

MC28. Planejamento_referências bibliográficas de P4

O professor P4 é um pouco mais simplista em sua concepção quando considera que o planejamento auxilia em relação ao conteúdo a ser ensinado facilitando o processo de ensino pois ...não chego boiando na sala de aula. Percebemos que entende o ensino 
como uma transmissão de conhecimentos e que, portanto basta saber qual conteúdo deverá "passar" para a sala. Então, seu foco principal está nos conteúdos selecionados e não em um objetivo de ensino-aprendizagem.

Elabora o plano de curso para cumprir as solicitações da escola, de forma burocrática, porém percebe que este pode ser útil, ...você acaba usando, acaba auxiliando.

O planejamento acontece no início do ano e P4 elabora sozinho o plano de Química. Ele sente a falta de outros professores da mesma disciplina para trocar experiências e idéias. Na escola em que trabalha há somente mais um professor de Química, mas em momento algum eles sentaram juntos para discutir sobre a disciplina.

Como referência bibliográfica para o planejamento diz que utiliza mais de um livro didático dependendo do assunto que será estudado.

\section{B. Dados sobre a elaboração do plano de curso}

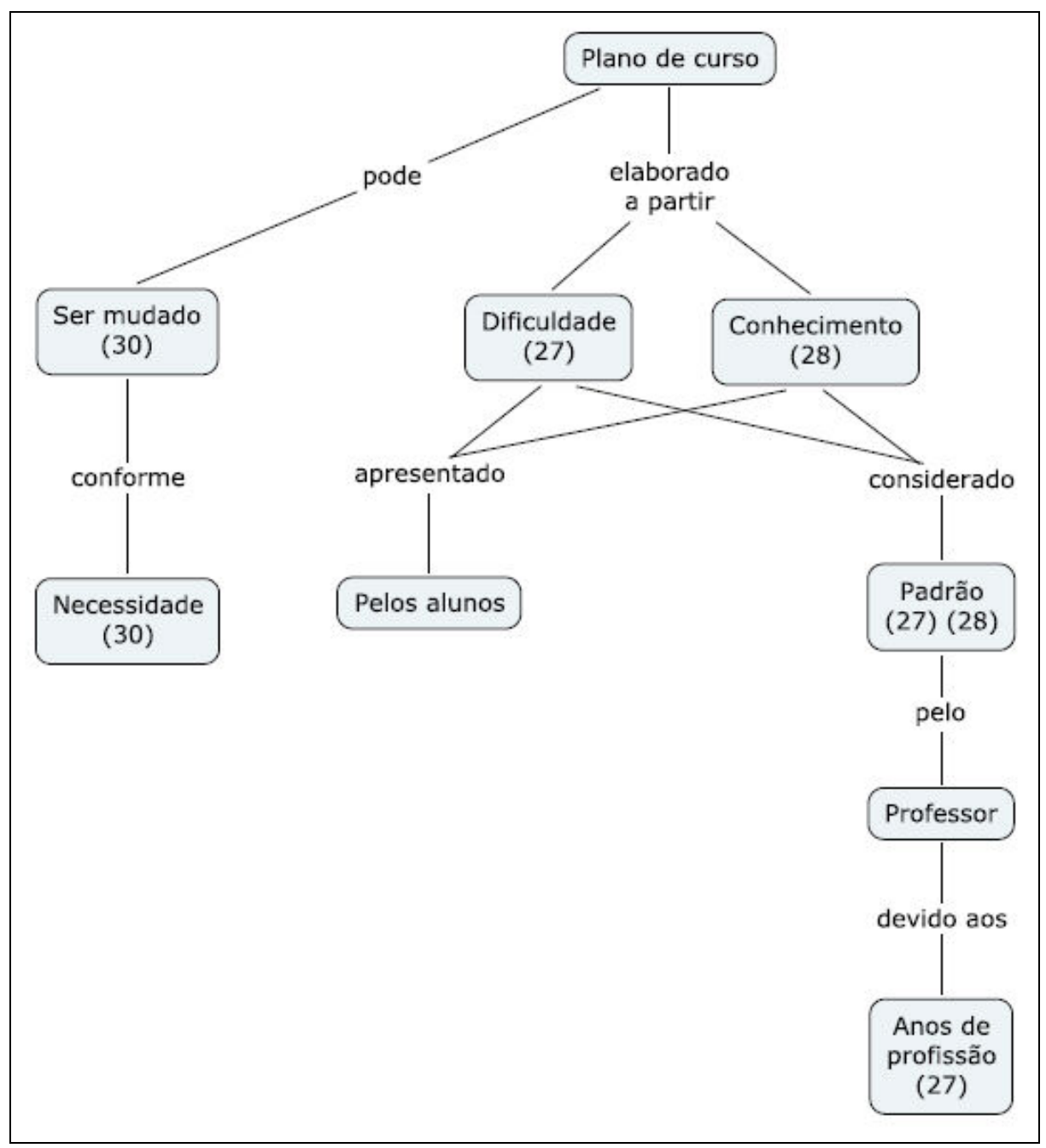

MC29. Plano de curso_pré-requisitos de P4 


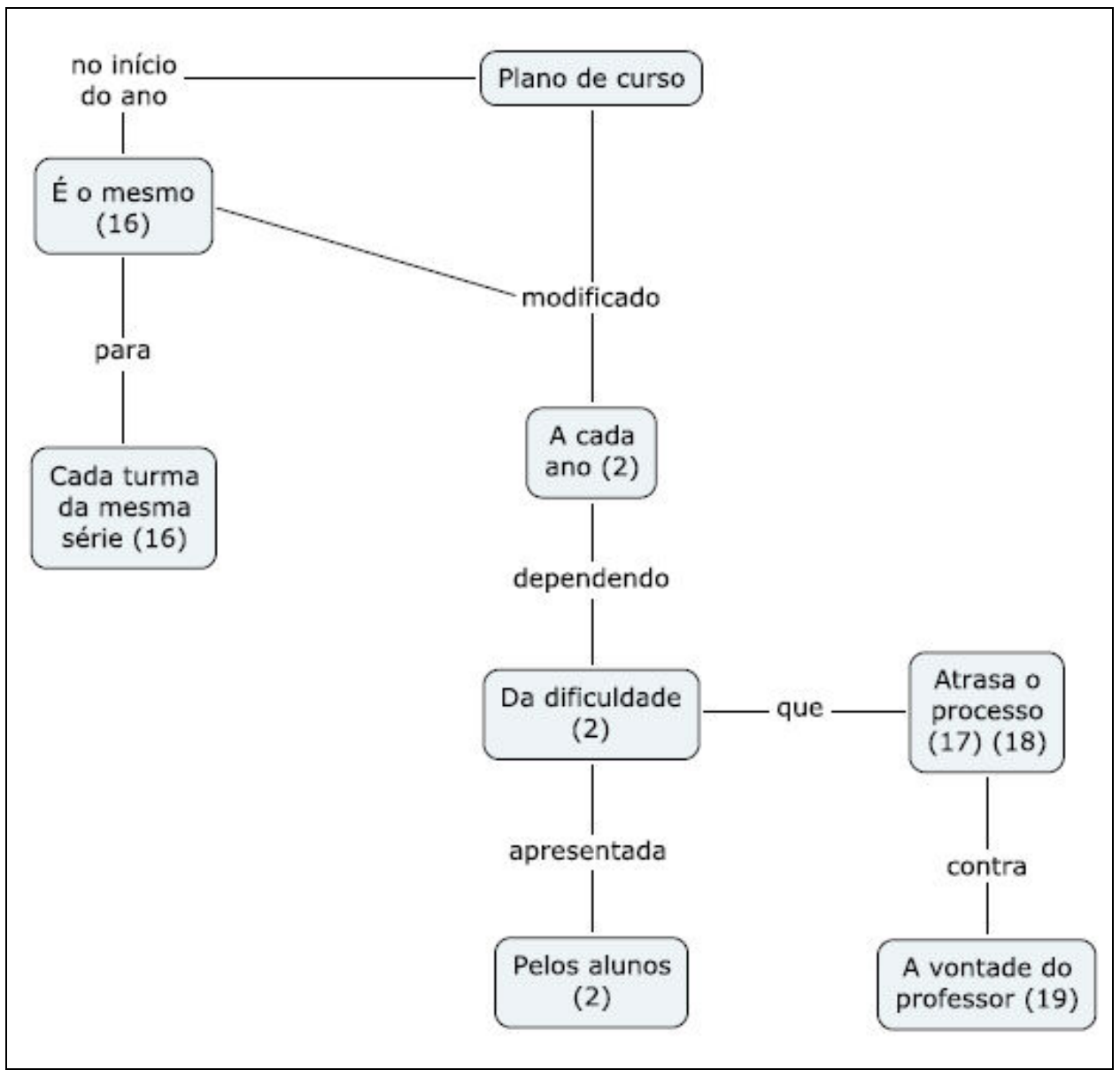

MC30. Plano de curso_características de P4

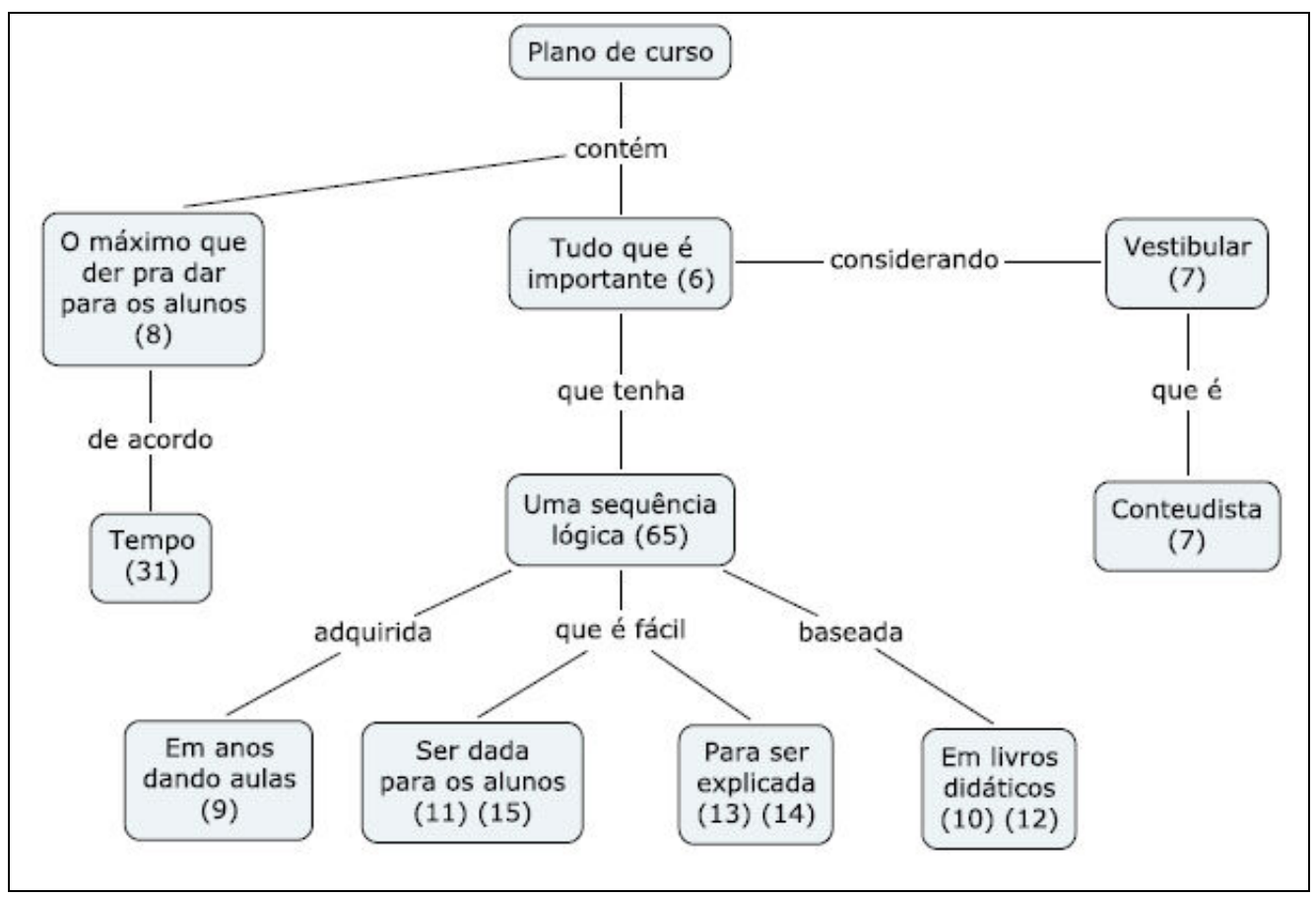

MC31. Plano de curso_seleção de conteúdos de P4 


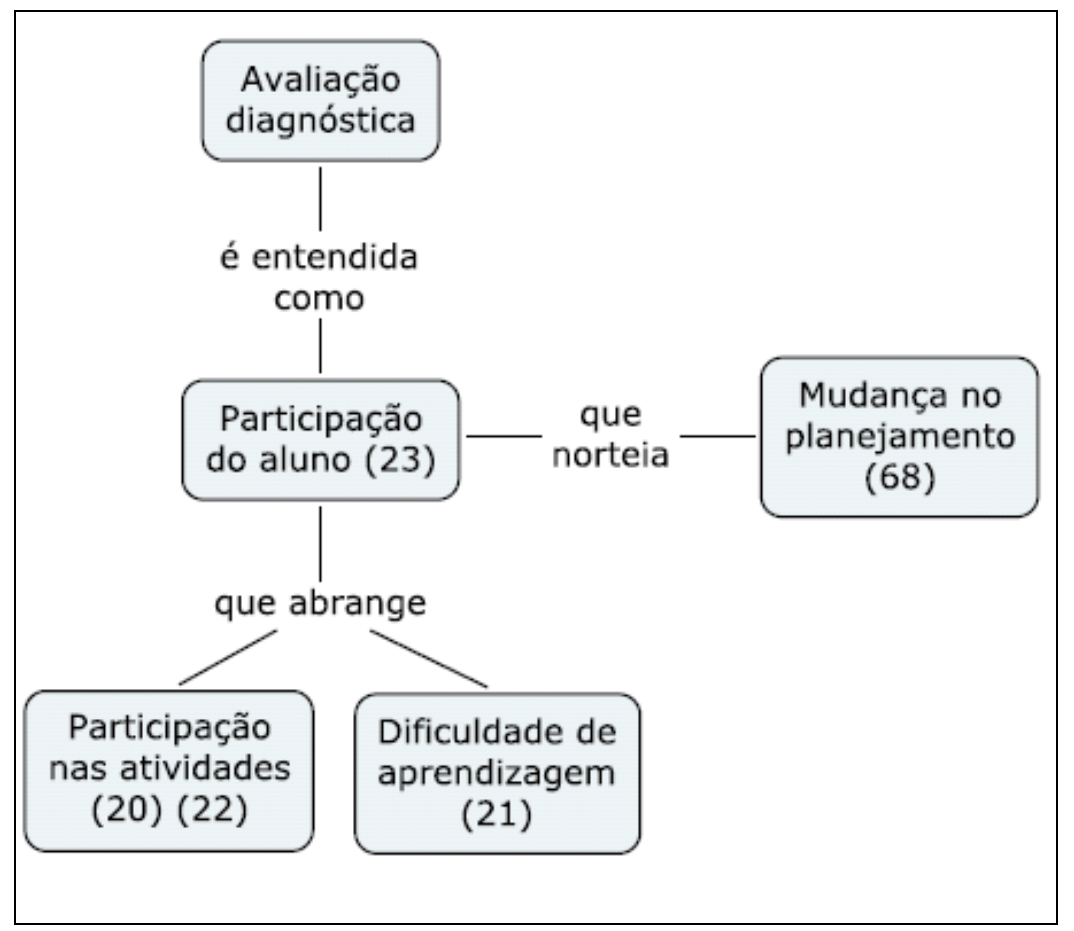

MC32. Plano de curso_avaliação diagnóstica de P4

Ao elaborar seu plano de curso no início do ano, P4 considera as dificuldades apresentadas pelos alunos e também o seu conhecimento sobre os conteúdos que são básicos para o ensino de Química, adquirido com anos de profissão.

Seu maior referencial para a seleção de conteúdos é o livro didático, já que este mantém uma "seqüência lógica". Percebe-se que esta "seqüência lógica" já foi interiorizada pelo professor quando diz uma seqüência lógica que eu adquiri já nesses anos dando aula. Acredita que tudo deve ser ensinado e que o tempo é determinante na escolha dos conteúdos.

O professor P4 considera também que essa seqüência deva ser fácil para os alunos aprenderem e fácil para ele ensinar, pois se ele não dominar aquele conteúdo com certeza não será incluído no planejamento. Isto fica evidente quando questionado sobre o fato de não constar "Termoquímica" em seu planejamento e constar "Radioatividade" e de como ele fazia estas escolhas. Ele explica, vejo que os dois são importantes. Mas vejo o que é mais fácil, eu tenho mais facilidade para explicar radioatividade. Termoquímica eu tenho dificuldade.

Não considera as concepções prévias dos estudantes ao elaborá-lo, utilizando a avaliação como verificador da aprendizagem. Tem como principal norteador o vestibular e sua própria experiência acadêmica. 


\section{Os planos de curso pré e pós-projeto}

\section{PLANEJAMENTO ESCOIAR ANO LETIVO 2005}

OBJETIVUS GERAIS DA ESCOLA: Criar condiçôes para o aluno se constituir como cidadão, subsidiando-o para a construção de una consciència critica e conseqüentemente transformando-o em agente modificador do meio. Para que tal objetivo seja alcançado e necessario que haja uma ponte entre o conhecimento aprendido na escola e nat sua aplicabilidade no dia a dia deste aluno

\section{Professores:}

Disciplina; Quimica

\section{OBJETIYOS GERAIS:}

Mostrar ao aluno que a quinica i $_{\text {um }}$ meio e uma ferramenta para entender o mundo ¿ atuar sobre ele como cidadào comprometido. a sua auto estima e prevençào de produtos quimicos

Mostrando para o aluno que a quinica está no nosso dia a dia e que muitas vezes as informaçōes veiculadas pelos meios de comunicaçōes são superficiais, ironnicos ou exageradamentes tecnicos. A quimica não e vilä, mas pode ser muitas vezes soluçôes para os problimas como exemplo poluição.

\section{OBJFTIVOS ESPECÍFICOS}

Apresentar os fatos hipoteses e leis qumicas que ajudaram o aluno a entender e atuar em problemas concretos em seu pais

\section{ENSINO MÉDIO MANHÃ E NOITE}

\section{COlegial}

Definições de stbstancias e tipos de misturas; separaçôes de misturas

Mudança de estados fisicos,

Modelos atomicos.

Leis ponderais.

Distribuição eletrònica

Tabela periodica , família, fundamentos de ligações químicas ; jònica e covalente,

Acidos e bases 


\section{COLEGLAI.}

Suluçòes - concentraçà densidade titulo.

Diluição de soluçôes

Radioatividade

tquaçòes gerais de gases.

Mol - estequiométrica.

Noçòes de eletroquimica

\section{COLEGIAL}

Qumica orgànica

Propriedades do carbono

Funçōes orgànicas: hidrocarbonetos alcoois, cetona. aideido, acidos carboxiticos, Vomenclaturas.

Reaçoes quimicas. de adição e de substituiçào

Polimeros

\section{AVALIACÕES}

I rabathos individuais e en grupo

Avaliaçoes escritas mulitipla esculha (testel e/ ou dissertativa

$V$ istos em atividades feita em sala de aula. como por exemplo. em exercicios

\section{ENSINO - F.JA}

\section{COI.FGIAL}

Definiçoes de substancias e tipos de misturas. separaçoes de misturas.

Mudança de estados fisicos,

Modelos atomicos.

Leis ponderais,

\section{COLEGIAL}

Soluçòs - concentraçào densidade. titujo.

Diluição de soluçōes

Radioatividade

\section{COLEGIAI.}

Quimica orgänica

Propriedades do carbone

Funçoes oryanicas hidrocarbonetos, aicoois, cetona, aldeido. acidos carboxilicos, Nomenclaturas. 


\begin{abstract}
AVALIACÕES
Trabalhos: individuais e em grupo

Avaliações escritas múltipla escolha (teste) e ou dissertativa.

$\checkmark$ istos em atividades feita em sala de aula. como por exemplo, em exercicios
\end{abstract}

BIBLIOGRAFIA:

TERLKO Y> UTIMURA - Qumica Fundamental - volune único, editor FTD:

SARDELLA- ediçào compacta de quimica - volume unico . editora Atica.

GHRALDO JOSF COVRF - Quimica total, volume unico editora FTD

SOUZA MOTA HARTWIG -Quimia volume 1,2 e 3, editora scipione.

ISBERCO. Quimica volume 1,2 e3, editora saraiva

O planejamento de 2006, nas escolas estaduais, finalizou em meados de março. Neste momento, já havíamos perdido o contato com esse professor. Ele não era efetivo em sua escola e então a cada ano há uma nova escolha da escola em que irá trabalhar. Procuramos via telefone e e-mail, mas não obtivemos resposta, por isso não temos o plano de curso de 2006 de P4.

Ainda assim, podemos analisar o plano de 2005 e perceber que este é único para diferentes níveis de ensino (Ensino Médio e Educação de Jovens e Adultos) no que se refere aos objetivos e avaliações. Só o conteúdo para o EJA é menor do que para o EM, já que o número de aula neste segmento é menor.

Nada consta sobre a metodologia que será utilizada, o que deveria ser diversa diante de um público com características tão distintas. A seqüência do que será dado é registrada apenas no diário para poder saber o que vai falar com os alunos.

Os objetivos gerais e específicos nos apontam um professor conteudista preocupado em transmitir conhecimentos. Os verbos "mostrar" e "apresentar" são exemplos de que o professor não se preocupa com o aprender.

P4 detalhou ainda a bibliografia, que neste caso são os livros didáticos utilizados para dar as aulas. Não são as referências para pensar sobre o ensino de Química e elaborar o seu plano. 


\section{Dados do questionário pós-projeto}

O professor P4 teve muita dificuldade para trabalhar com a proposta do LabVirt. Em visita à sua escola, percebemos que esse não tinha domínio sobre a sala e tão pouco segurança em sua atuação.

Por isso, não conseguiu trabalhar com o LabVirt. Embora tenha tentado, os alunos não respondiam às suas expectativas, mesmo tendo elaborado o plano de aulas. Esse professor não conseguiu seguir seu plano. Tentou fazer algumas mudanças, as quais não surtiram o efeito esperado em sala de aula.

\section{E. Discussão dos dados}

P4 é uma pessoa simples que não tem acesso a recursos tecnológicos e não teve uma boa formação inicial, portanto sua prática pedagógica está um pouco prejudicada. Apesar de se interessar por cursos de formação contínua tem dificuldades para colocar em prática o que aprende.

Sua concepção sobre planejamento é refletida em seu plano na medida em que o foco está no conteúdo programático. Com isso, entendemos porque o professor não incluiu a metodologia em seu plano, porque sua aula é apenas expositiva com exercícios de aplicação de conceitos elaborados pelo professor ou tirados dos livros didáticos. Ao tentar uma outra metodologia, não se sente seguro e não alcança os objetivos esperados nem o envolvimento dos alunos.

O plano é elaborado apenas porque a escola solicita e, portanto não é visto como um instrumento organizador e facilitador de sua prática. Não planeja suas aulas, com anos de prática já sabe o que fazer em sala, ...se tem um assunto que faz tempo que eu não vejo, eu dou uma olhada nos livros. 


\subsubsection{Professor P5}

A. Dados sobre a concepção de planejamento

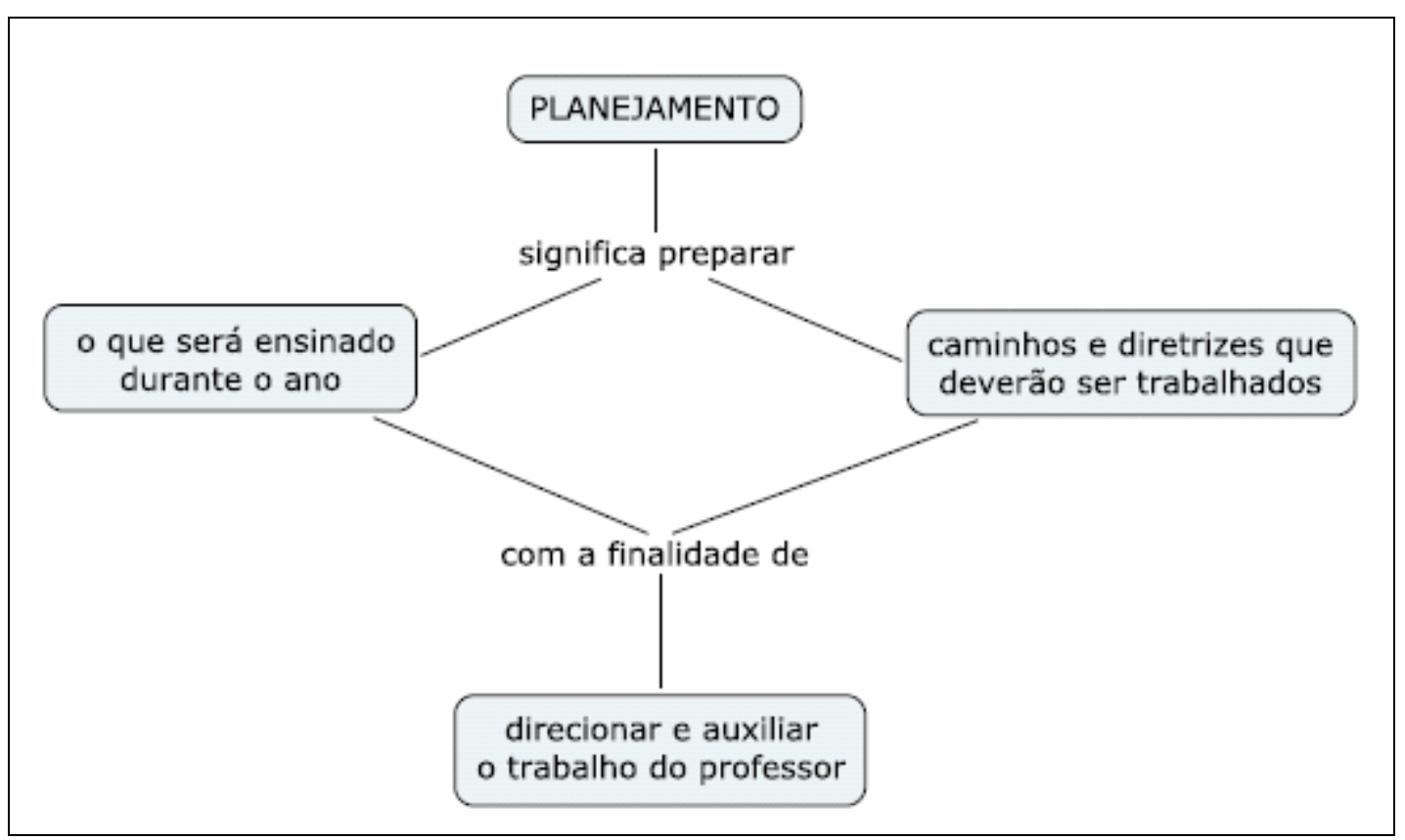

MC33. Planejamento_significado e finalidade de P5

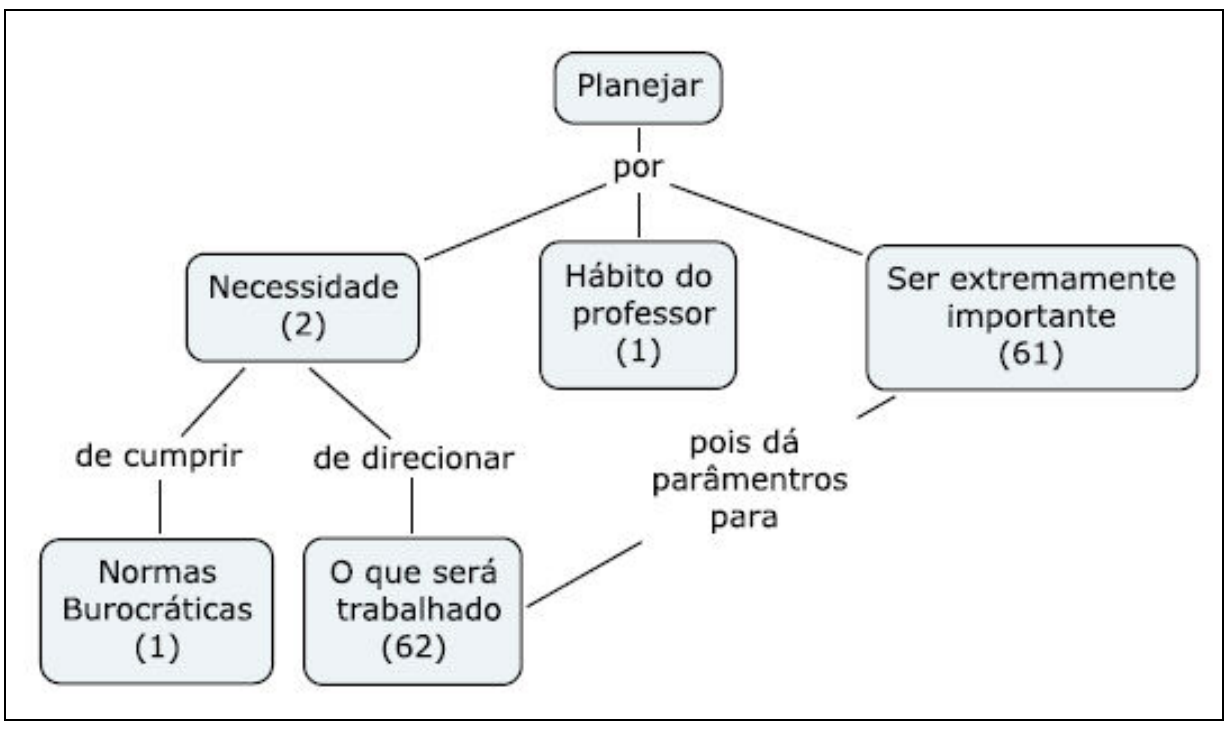

MC34. Planejamento_importância de P5 


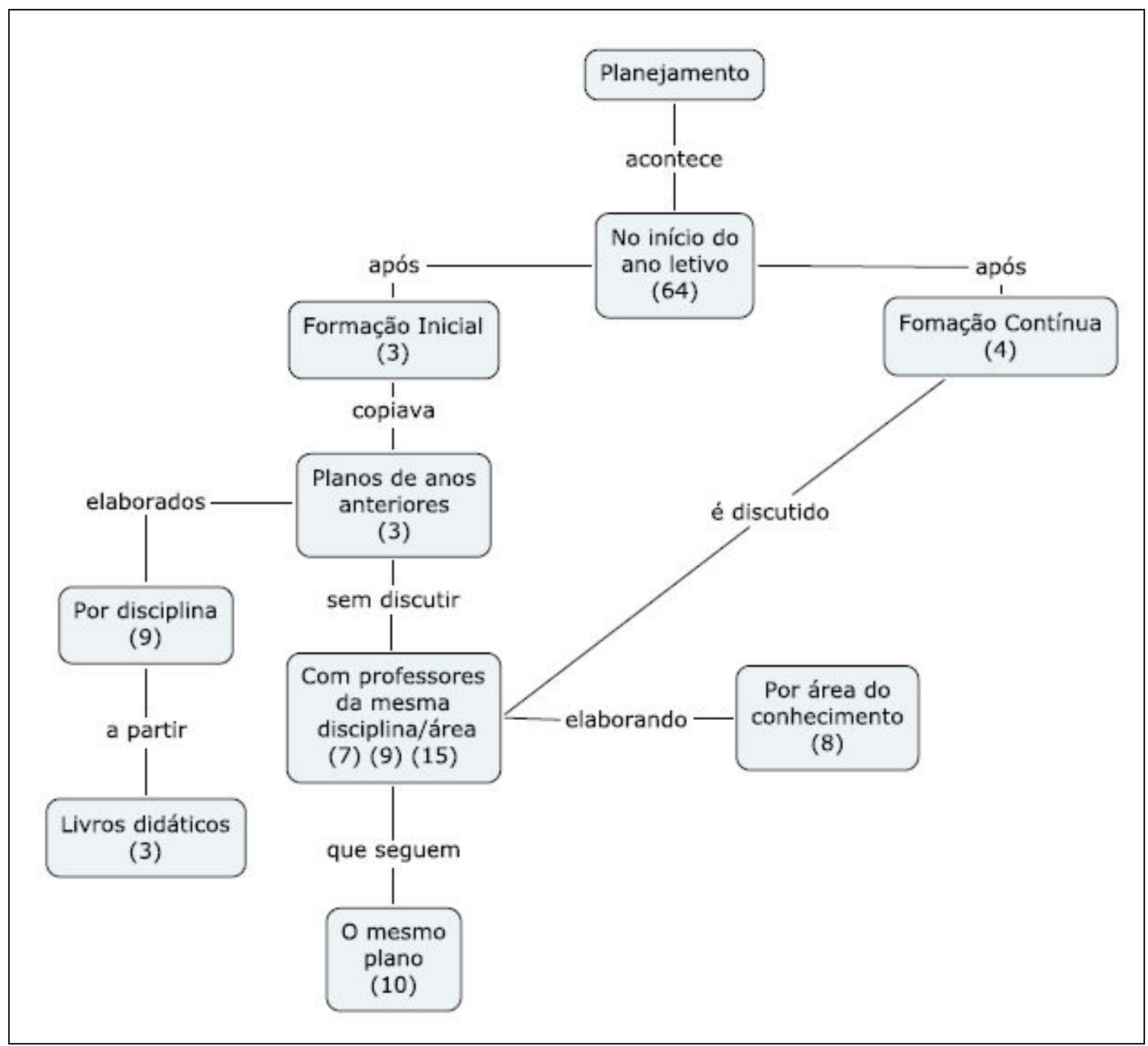

MC35. Planejamento_processo de P5 


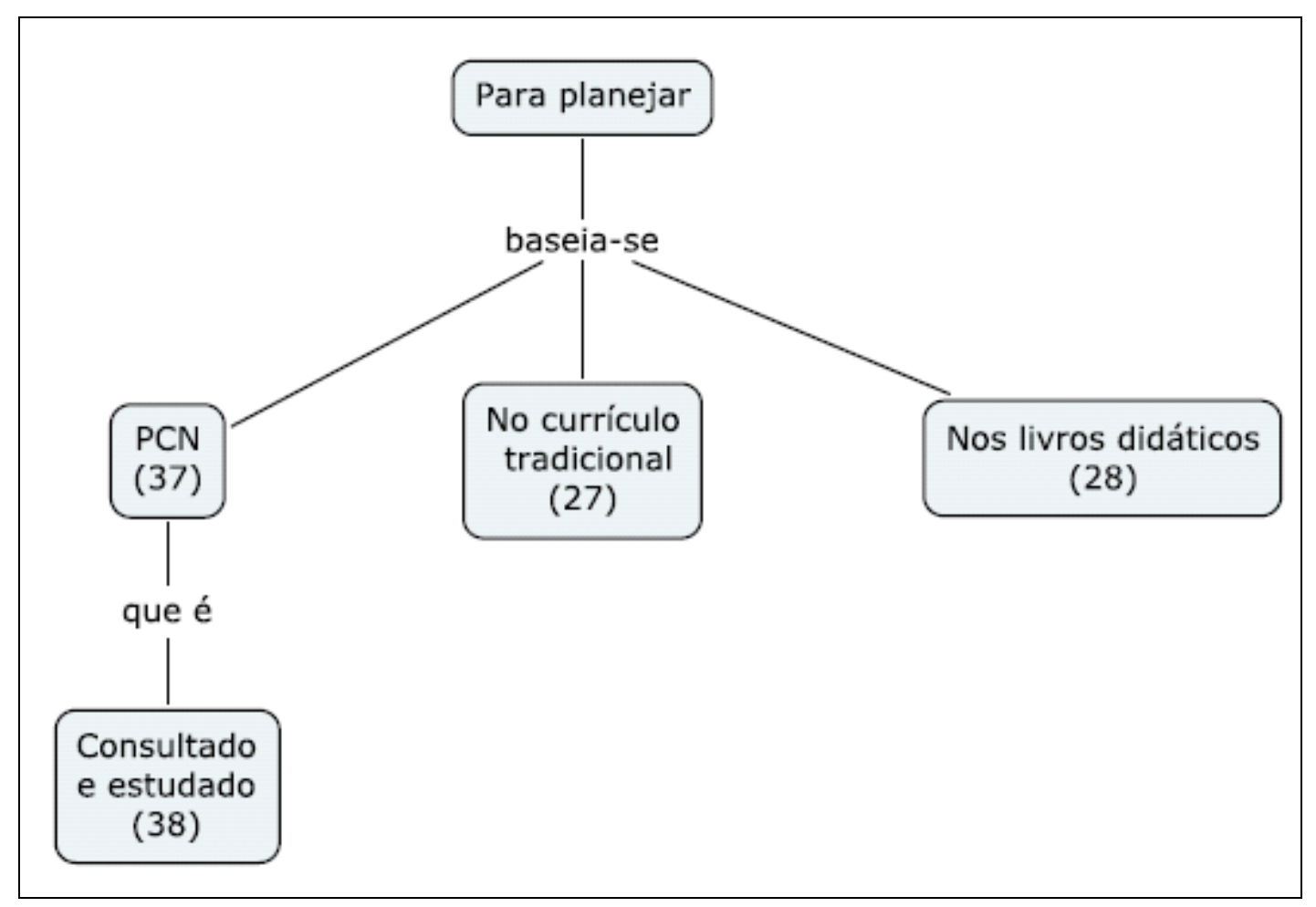

MC36. Planejamento_referências bibliográficas de P5

O professor P5 revela uma visão abrangente do planejamento quando considera que ele serve para preparar as diretrizes, os caminhos e o que será ensinado ao longo do ano. Pensa que o planejamento direciona e auxilia seu trabalho, mas também cumpre normas burocráticas solicitadas pela instituição escolar. Para ele, planejar já se tornou um hábito e é extremamente importante, pois dá parâmetro para o trabalho a ser desenvolvido pelo professor.

Com os conhecimentos adquiridos em sua formação inicial elaborava o seu plano sozinho, pois, a gente não tinha essa oportunidade de se encontrar, copiando de anos anteriores e baseando-se somente em livros didáticos. Tendo participado de programas de formação contínua, mudou o processo do planejamento e hoje, juntamente com outros professores, elabora seu plano por área do conhecimento para definir um tema para o projeto que é desenvolvido na escola.

Como referências bibliográficas para o planejamento baseia-se nos PCNs, apesar de não conhecê-los por inteiro. 
B. Dados sobre a elaboração do plano de curso

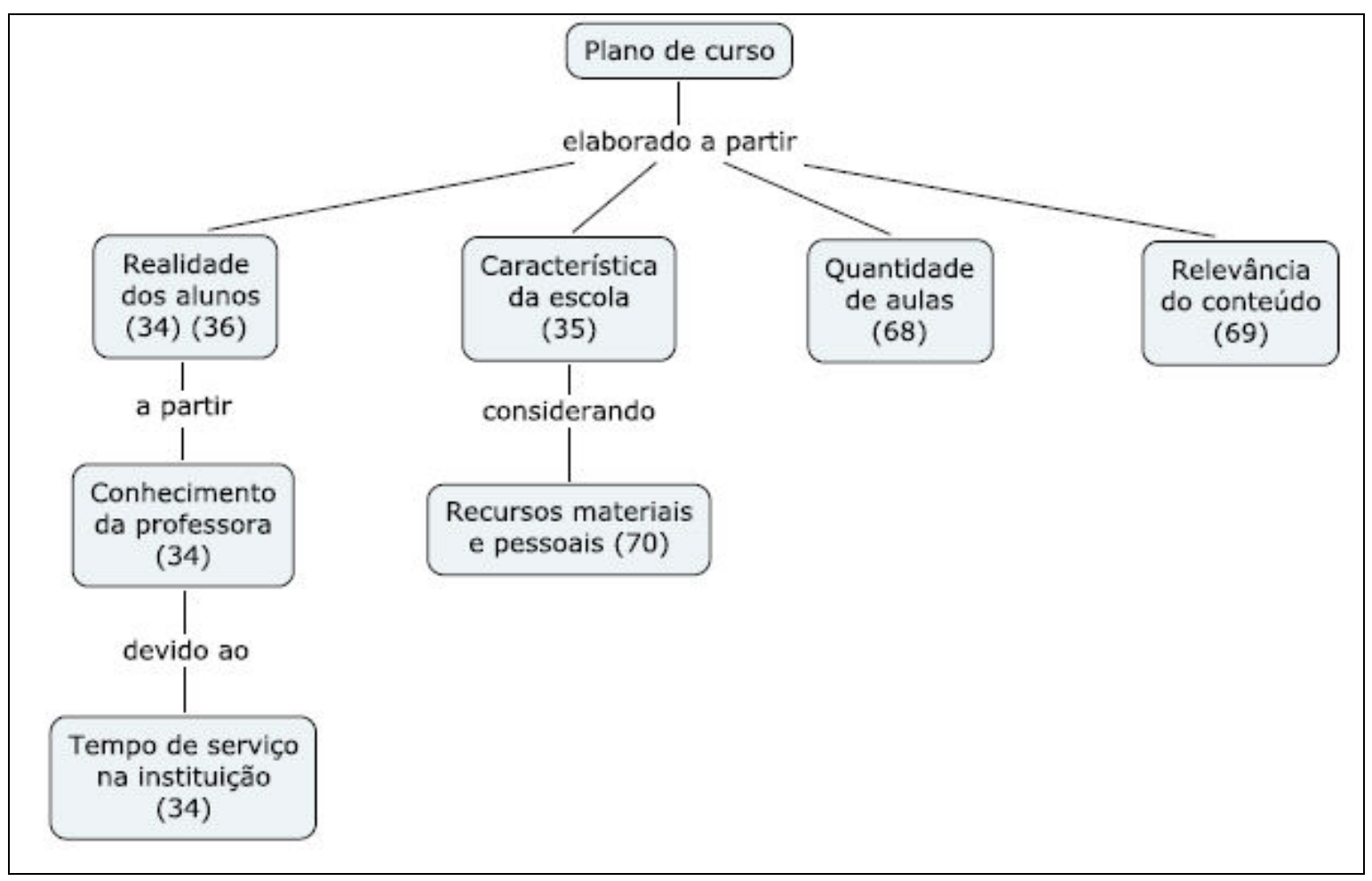

MC37. Plano de curso_pré-requisitos de P5

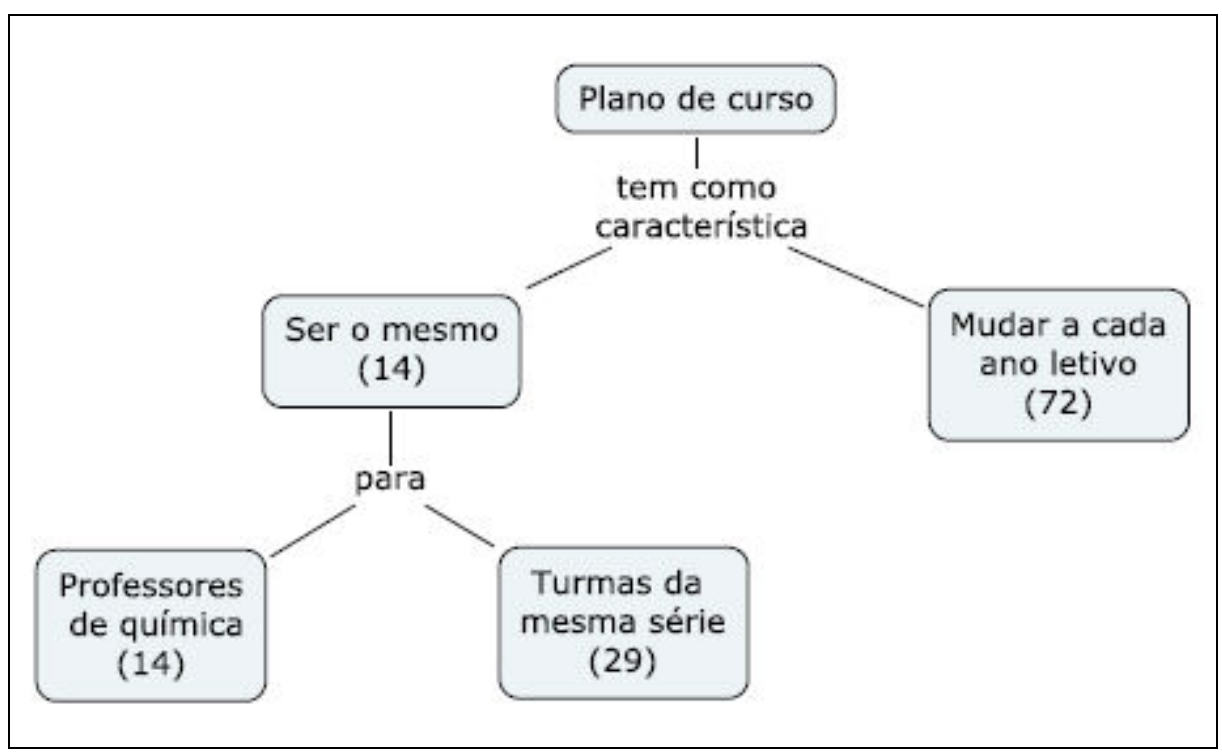

MC38. Plano de curso_características de P5 


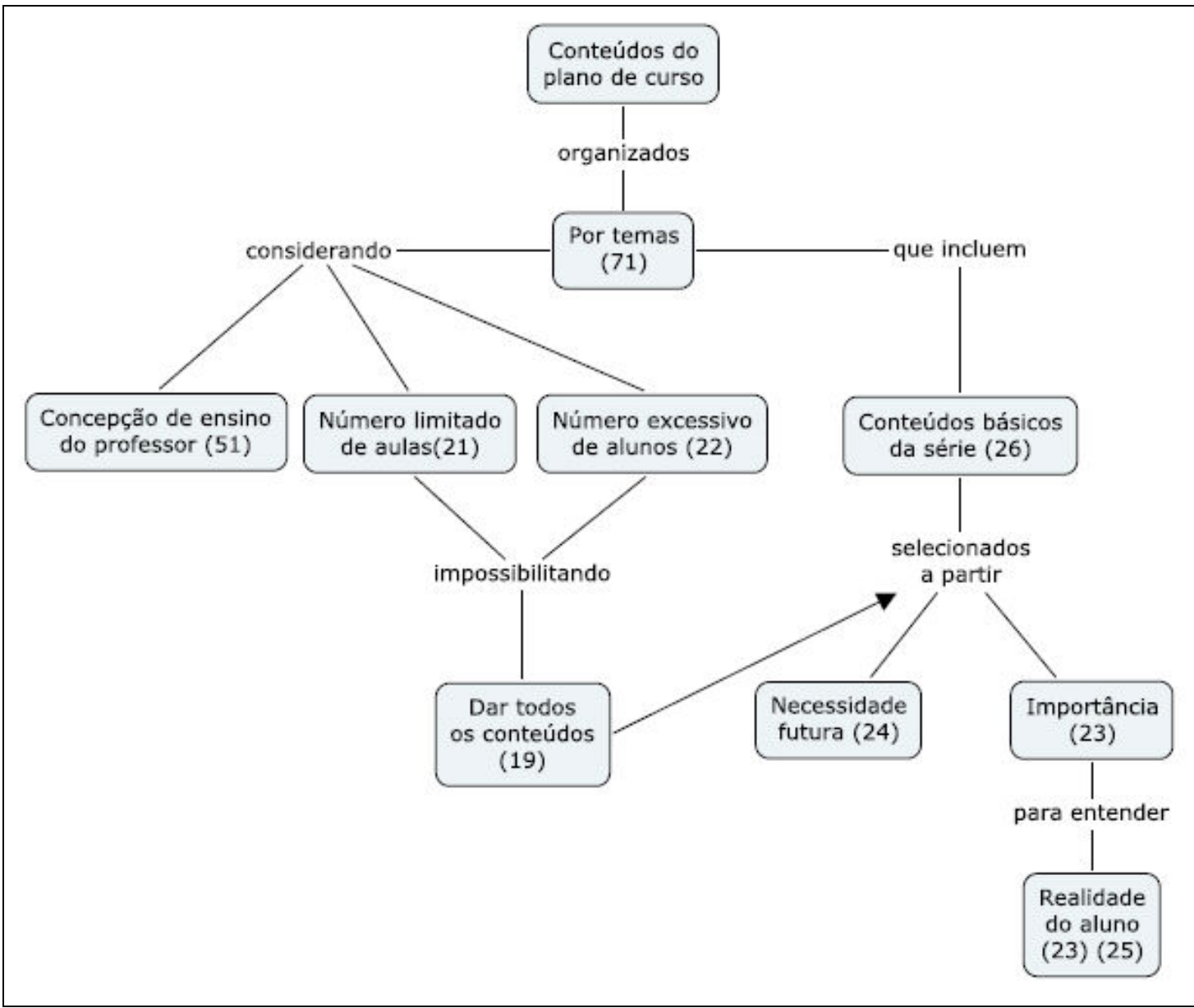

MC39. Plano de curso_seleção de conteúdos de P5

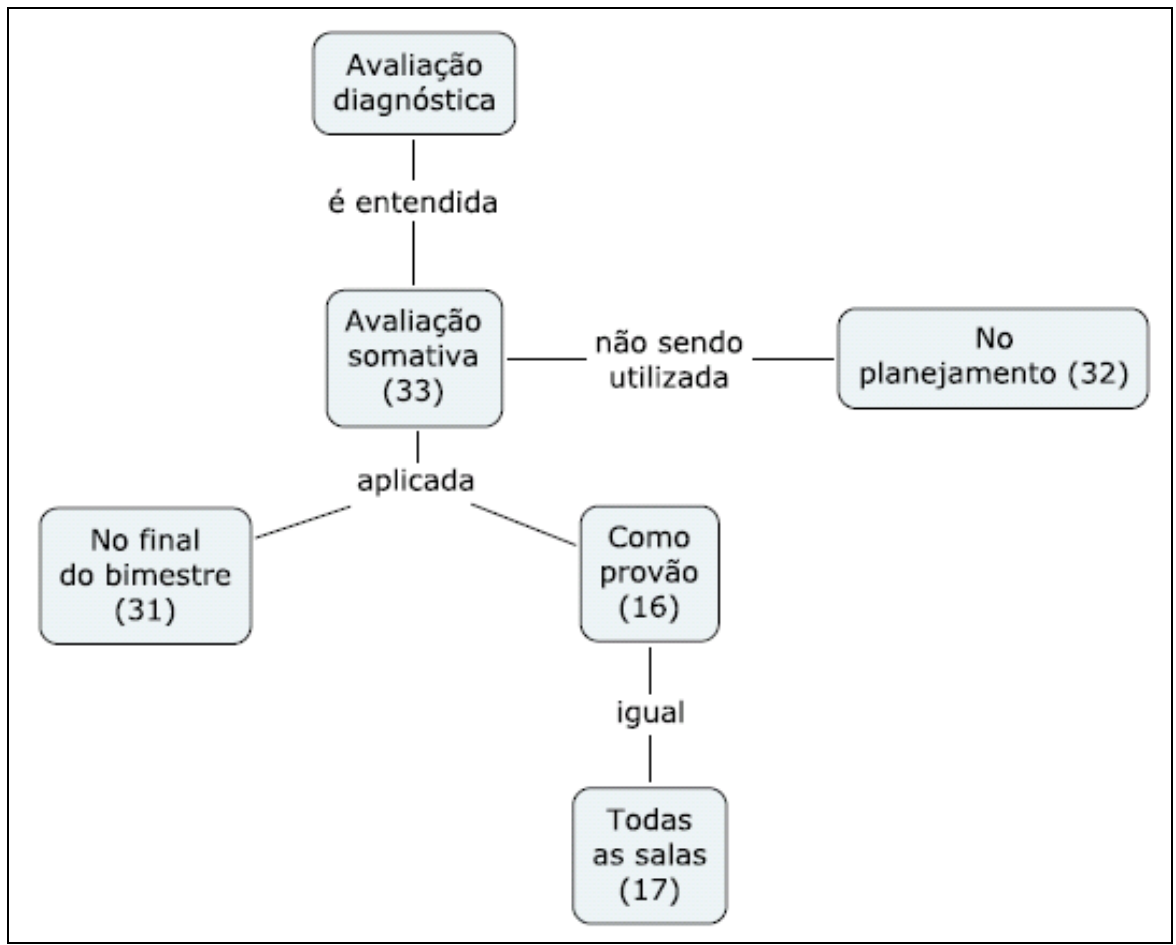

MC40. Plano de curso_avaliação diagnóstica de P5 
Para elaborar seu plano de curso, P5 considera a realidade do aluno que já é conhecida por ele pelo tempo que trabalha na escola. Não é feito um diagnóstico a cada início de ano para identificar particularidades da nova turma. As características da escola também são consideradas no que se refere aos recursos materiais e pessoais.

O professor P5 seleciona alguns conteúdos de Química em detrimento de outros dependendo do número de aulas por série e da relevância que tem para a turma, porque considera que ...não tem como dar todos os conteúdos..., ...o aluno não vai assimilar, não tem como.... Apesar de organizar seu ensino por temas geradores, relaciona-os com os conteúdos tradicionais estabelecidos para cada série tendo como referencial os livros didáticos. Isto fica claro quando afirma ...a gente não foge assim tanto do conteúdo da série, ...é o tradicional mesmo, nos livros didáticos.

Isto se contrapõe à idéia de que a seleção de conteúdos está relacionada com o cotidiano do aluno, com o que seria mais importante conhecer, para o aluno entender a realidade dele.

Diz que seu plano é modificado a cada ano porque surgem novas informações, textos e porque os alunos são diferentes, porém é o mesmo para todos os professores da escola e nas turmas da mesma série.

Para planejar, como já mencionamos, não faz um diagnóstico da turma. A avaliação é somativa envolvendo o conteúdo de todo o bimestre na forma de provão. E é por ele que o professor identifica se os alunos aprenderam ou não o conteúdo ensinado. 


\section{Os planos de curso pré e pós-projeto}

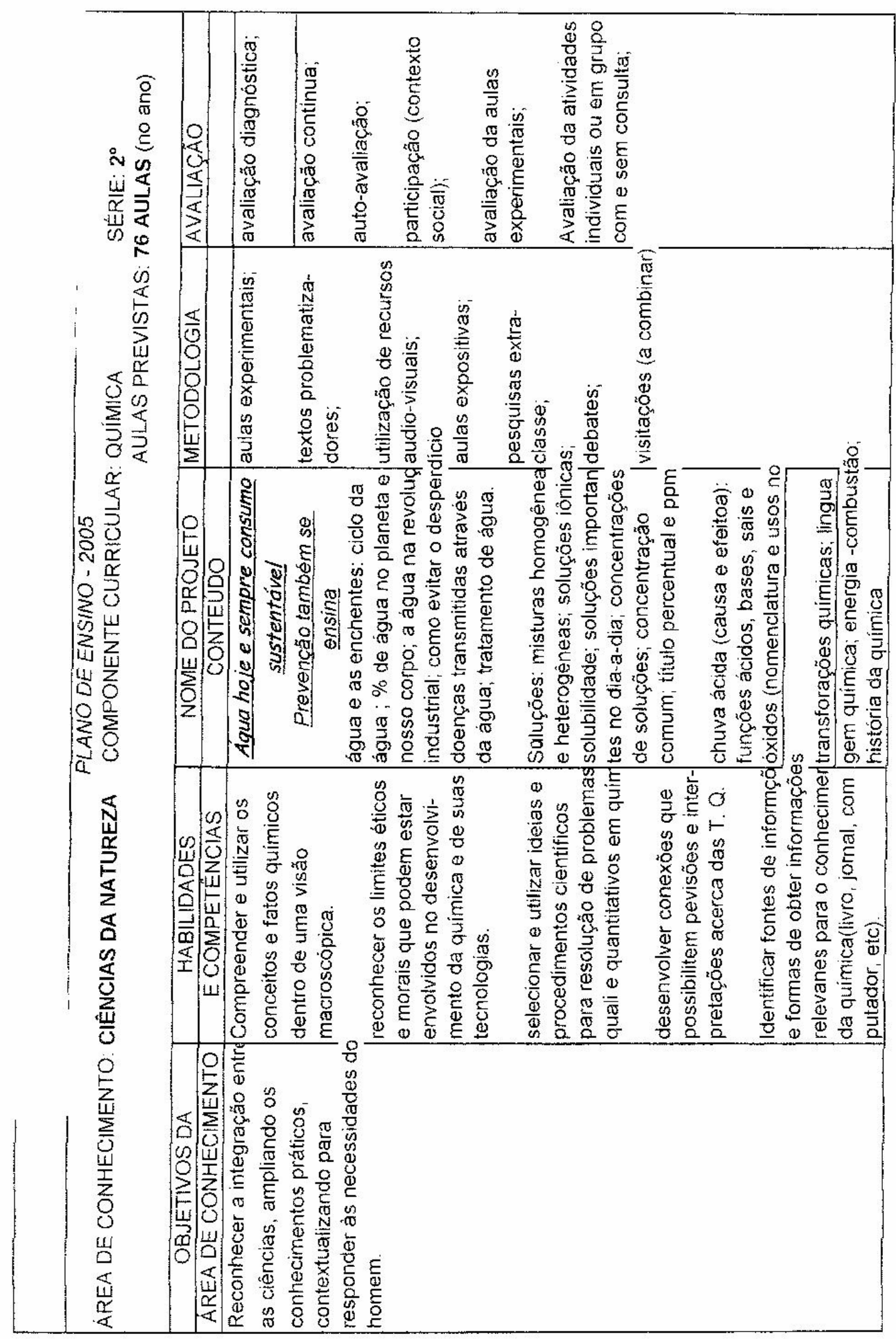


Planos de ensino de 2006

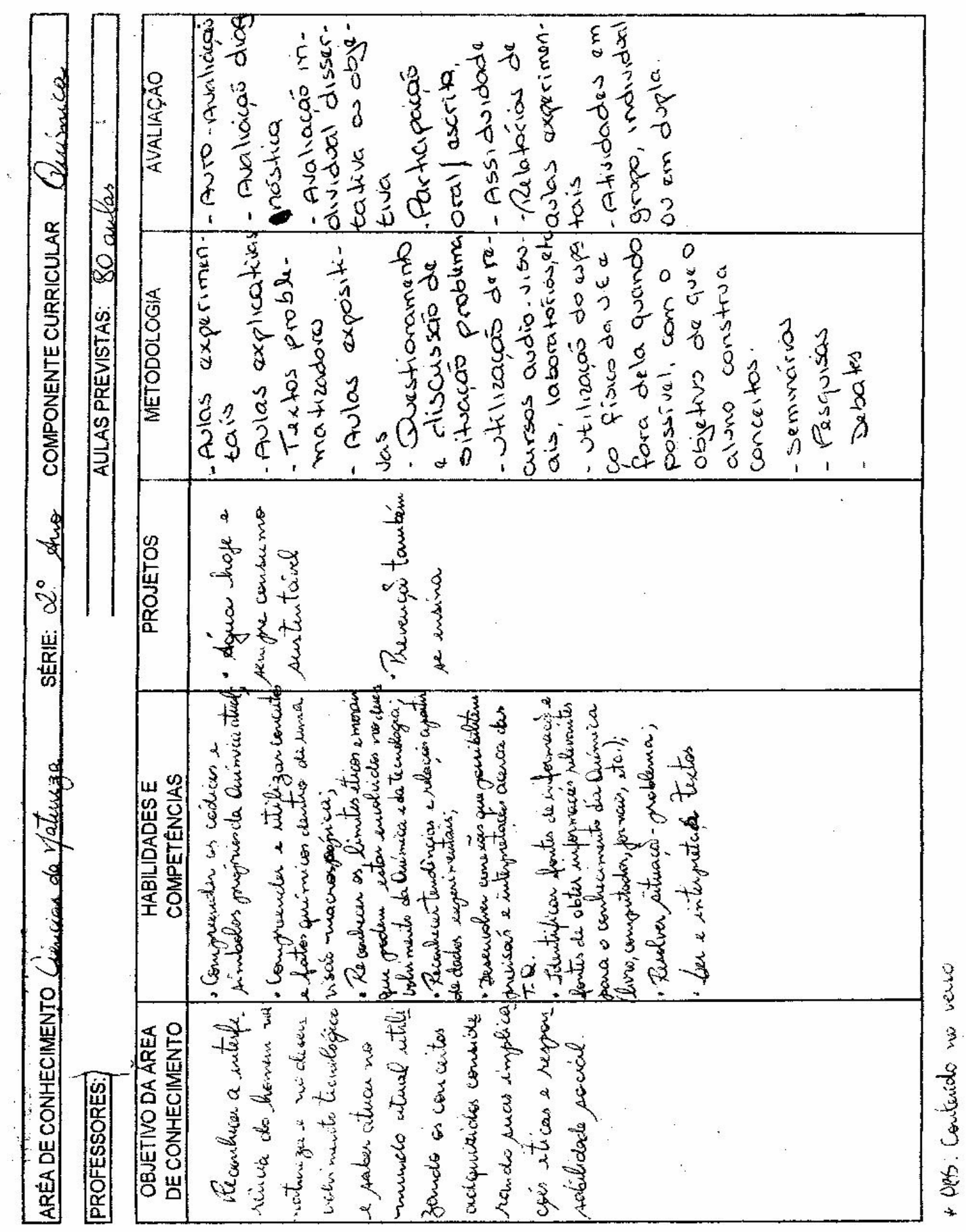




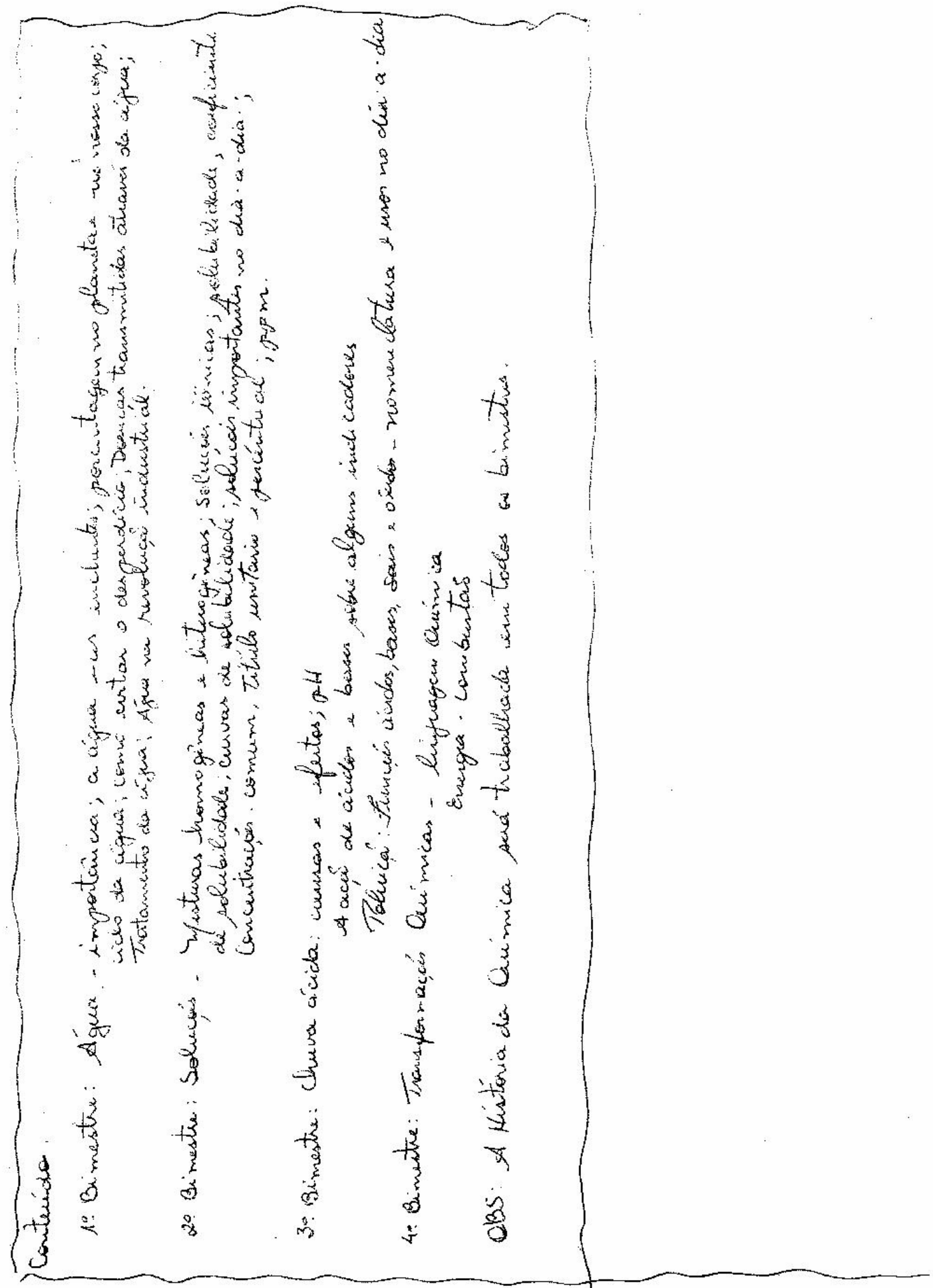




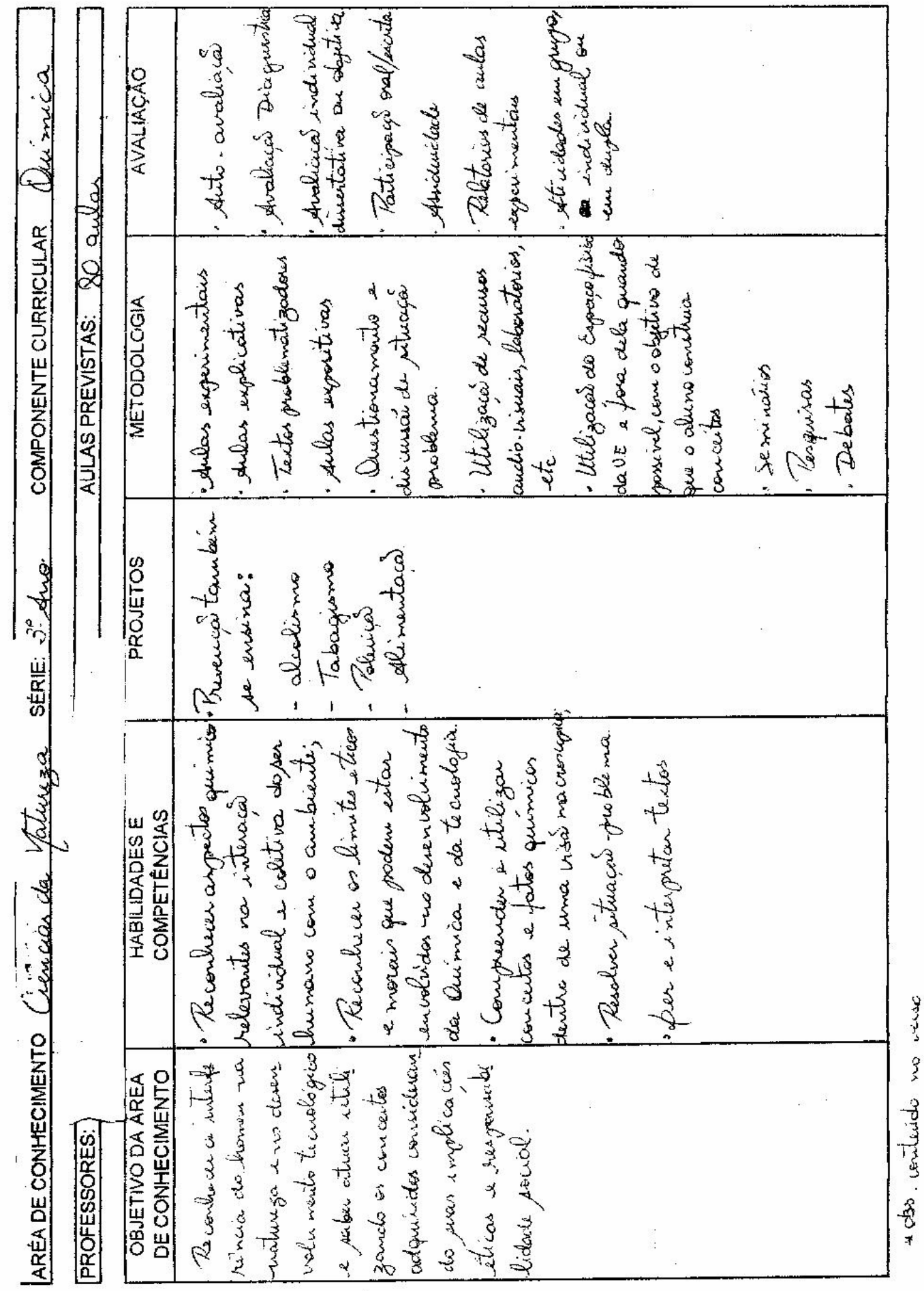




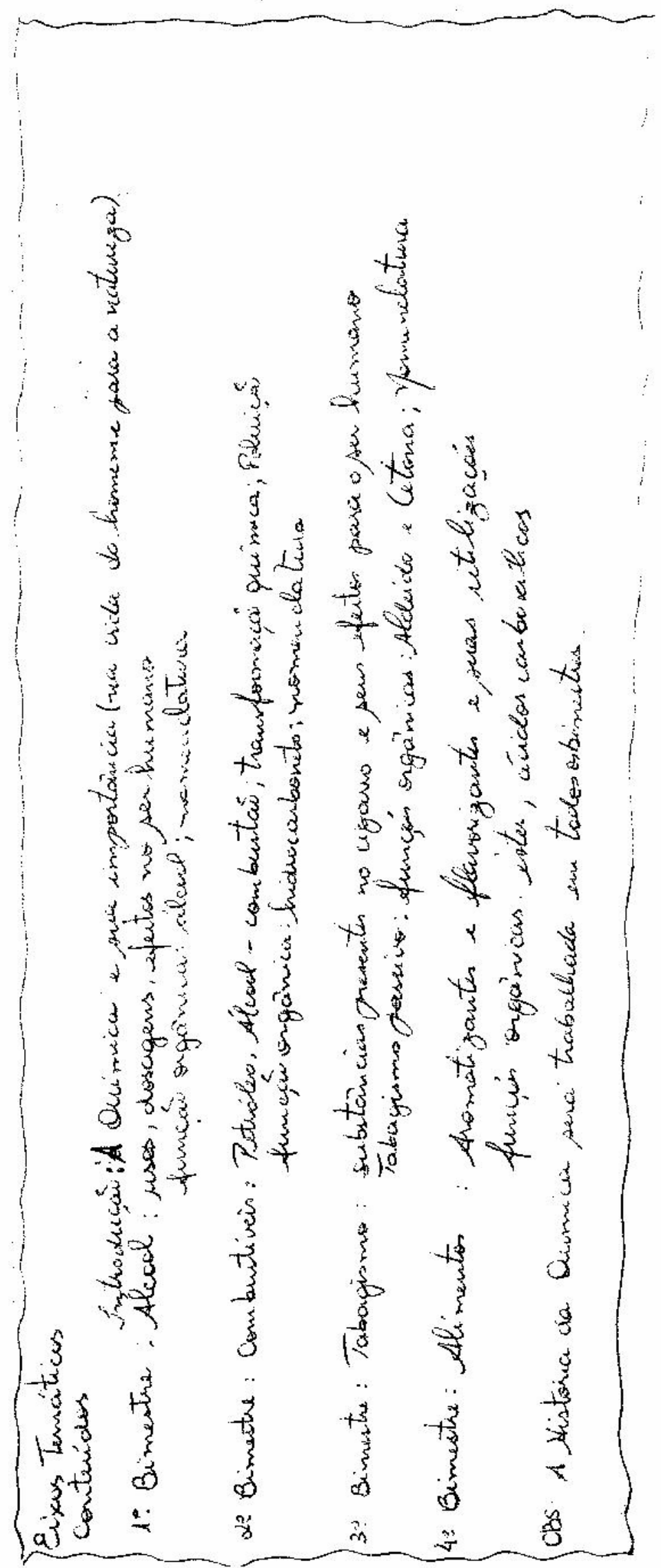


Os planos de curso de P5 estão formatados conforme formulário padrão adotado na maioria das escolas estaduais, em colunas, com pouco espaço para estruturar cada tópico. Isso demonstra o engessamento que a instituição causa no professor. Mesmo que esse sinta a necessidade de detalhar cada item fica inviável em um espaço tão pequeno.

Os objetivos são propostos por habilidades e competências a serem desenvolvidas ao longo do ano indicando que o planejamento está baseado nos PCNs. Essas habilidades e competências são diferentes para cada série apesar do objetivo da área (Ciências da Natureza) ser o mesmo.

Os conteúdos a serem estudados parecem ser os meios para abordarem os temas maiores dos projetos "Água hoje e sempre: consumo sustentável" e "Prevenção também se ensina". Não percebemos os conteúdos na seqüência tradicional dos livros didáticos.

De um ano para o outro P5 separou os conteúdos por bimestres, talvez para organizar melhor a sua prática, mesmo não sendo pré-estabelecido pelo formulário da escola. Entendemos isso como um avanço, pois este professor não se limitou a fazer somente o que a instituição solicitou.

\section{Dados do questionário pós-projeto}

P5 conseguiu trabalhar com a proposta do projeto e para isso elaborou com dificuldade seu plano de aulas, pois não está habituado a organizar sua prática aula a aula.

Sentiu que o fato de ter o plano de aula facilitou e direcionou os passos a serem seguidos para desenvolver o projeto com os alunos. Esse plano teve que ser refeito devido ao tempo que se gastou em cada etapa, principalmente na realização das encomendas.

\section{E. Discussão dos dados}

Podemos dizer que esse professor é coerente em suas concepções e sua prática. Como ele entende que o planejamento indica as diretrizes e os caminhos que deverão ser trabalhados, através de seu plano podemos saber como se dá o ensino em cada série do Ensino Médio, onde esse professor deseja chegar e quais caminhos ele irá percorrer para alcançar seus objetivos.

Entretanto, não fica explícita em seus planos a mudança que ele diz que ocorre a cada ano em relação aos conteúdos porque nos planos da $2^{\mathrm{a}}$ série são os mesmos em 2005 e 2006. 
É um professor que busca atualizar-se com programas de formação contínua e que consegue trabalhar com novas propostas, eu fiz três anos de Pró-Ciência e foi aí que eu comecei a modificar o meu trabalho em sala de aula.

\subsubsection{Professor P6}

A. Dados sobre a concepção de planejamento

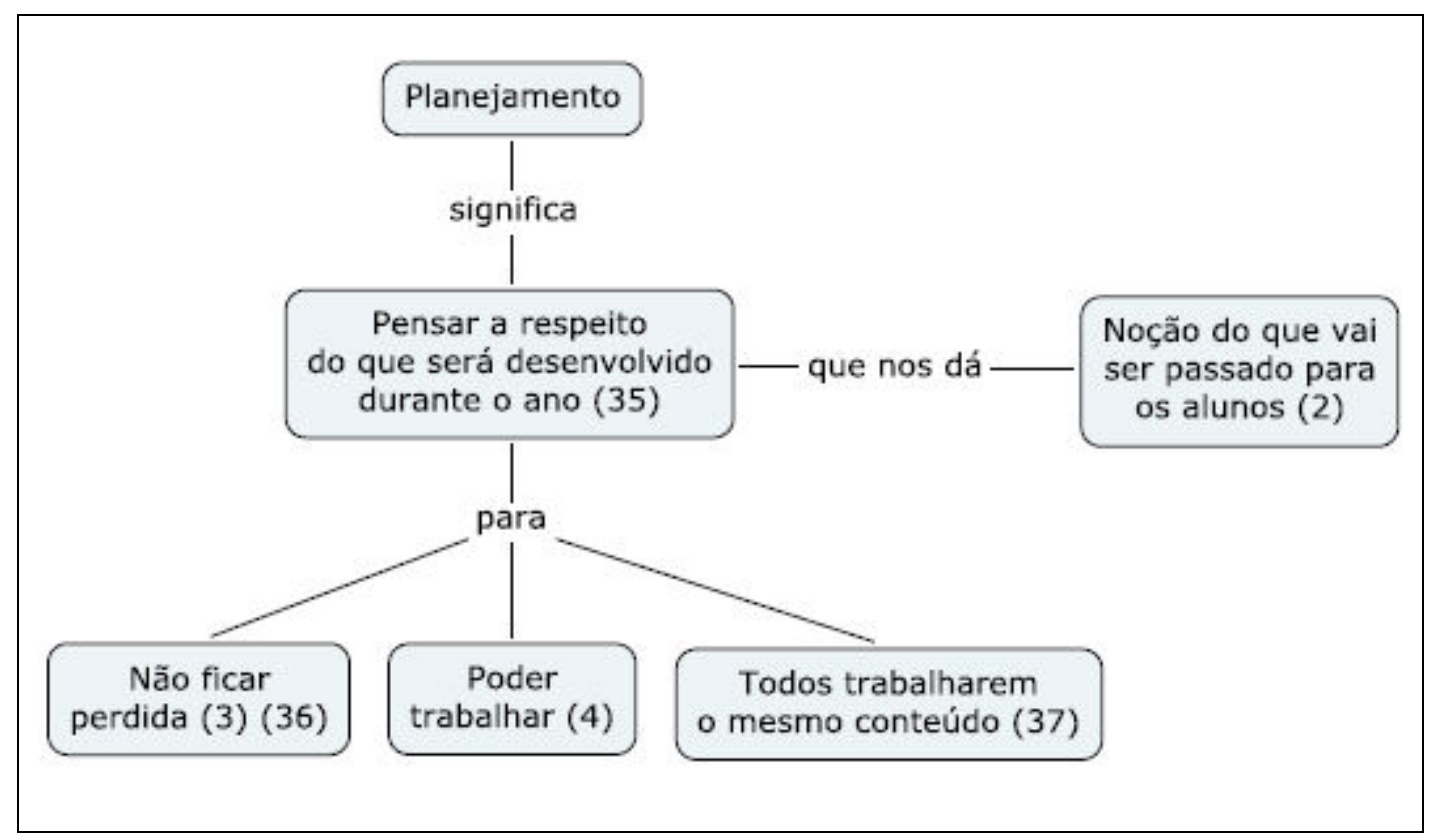

MC41. Planejamento_significado e finalidade de P6 


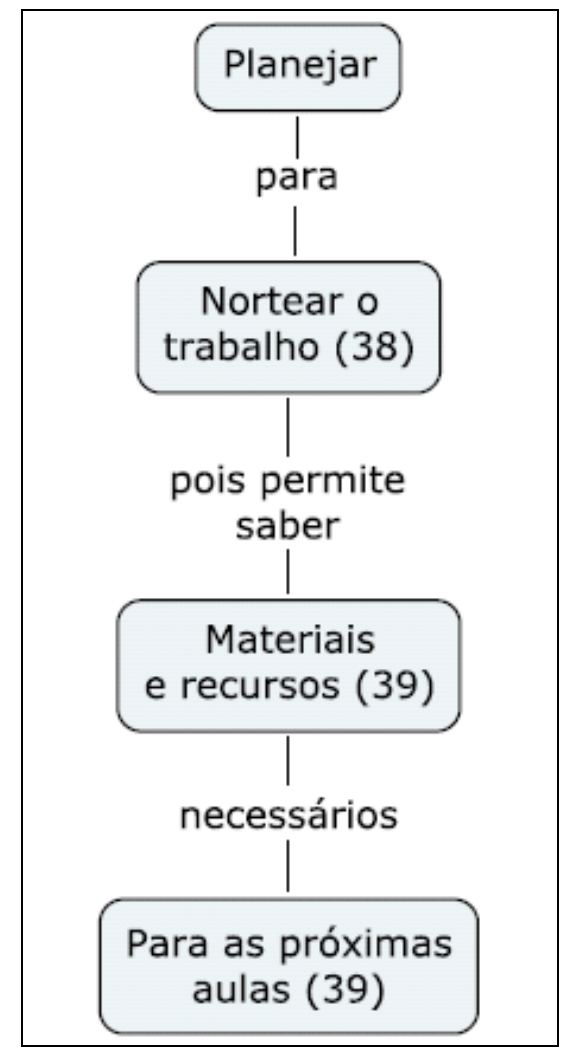

MC42. Planejamento_importância de P6

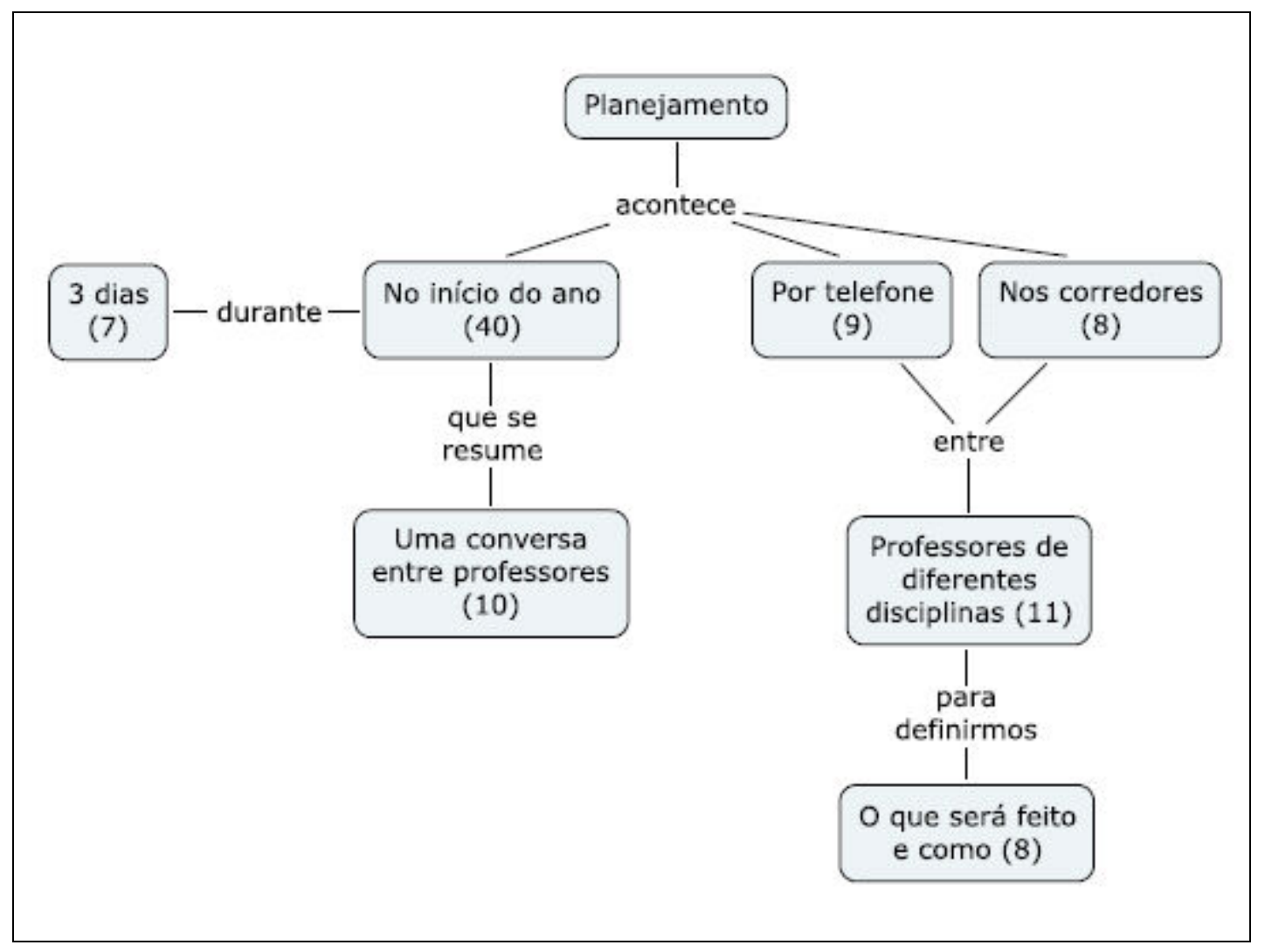

MC43. Planejamento_processo de P6 


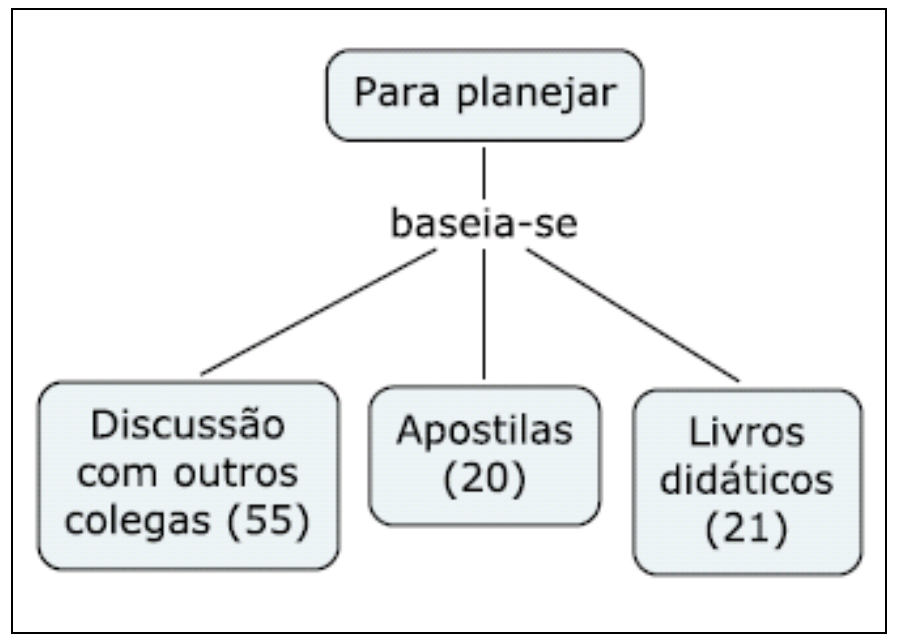

MC44. Planejamento_referências bibliográficas de P6

P6 entende o planejamento como um momento onde será pensado o que será desenvolvido ao longo do ano. Dessa forma ele se organiza e garante que todos os professores da mesma disciplina trabalhem o mesmo conteúdo na escola. Se não tivermos um planejamento... a gente se perde. O aluno vê três vezes a mesma coisa, outra coisa não vê. É uma bagunça.

A definição dos conteúdos que serão estudados se dá nos corredores ou por telefone com professores de outras disciplinas, já que nos 3 dias no início do ano, acontece apenas uma conversa com os professores.

Seu planejamento baseia-se na discussão com outros colegas, converso muito com a outra professora, ... converso com a professora de biologia, de educação artística e também nos livros didáticos e apostilas. 
B. Dados sobre a elaboração do plano de curso

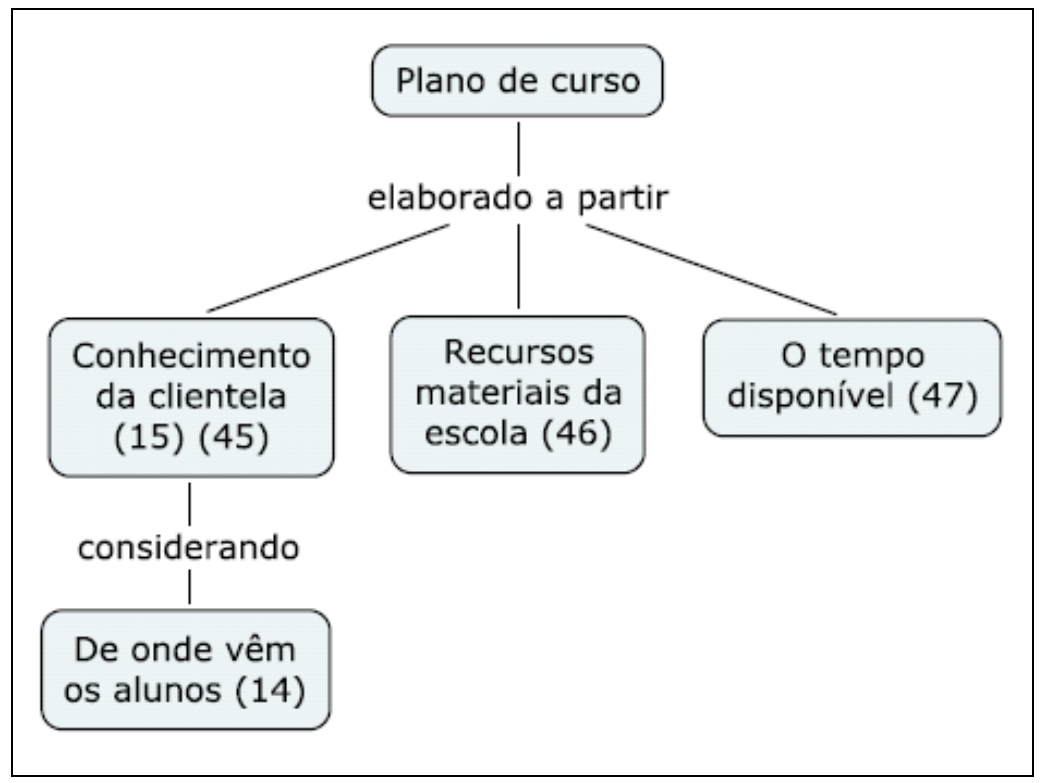

MC45. Plano de curso_pré-requisitos de P6

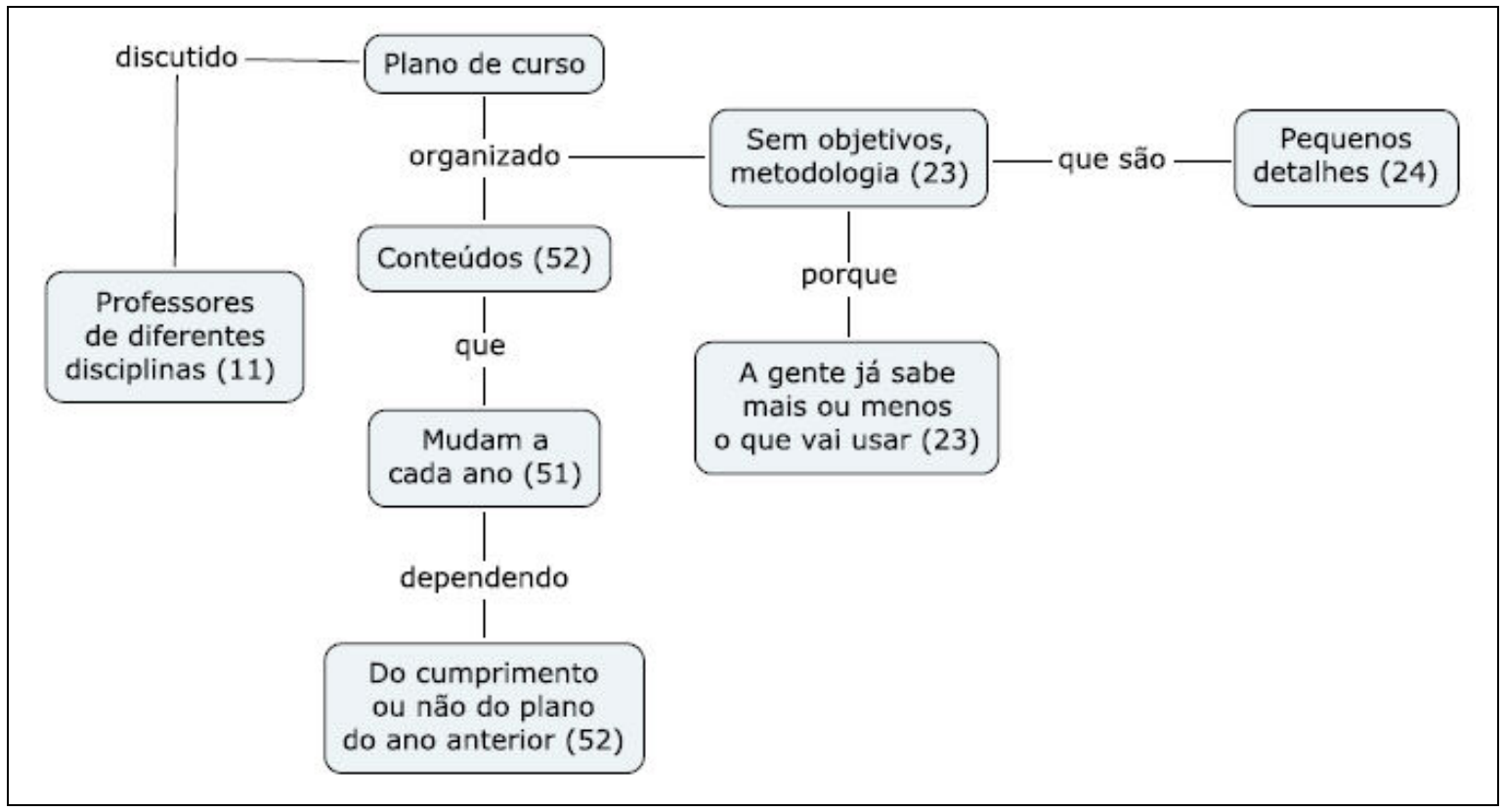

MC46. Plano de curso_características de P6 


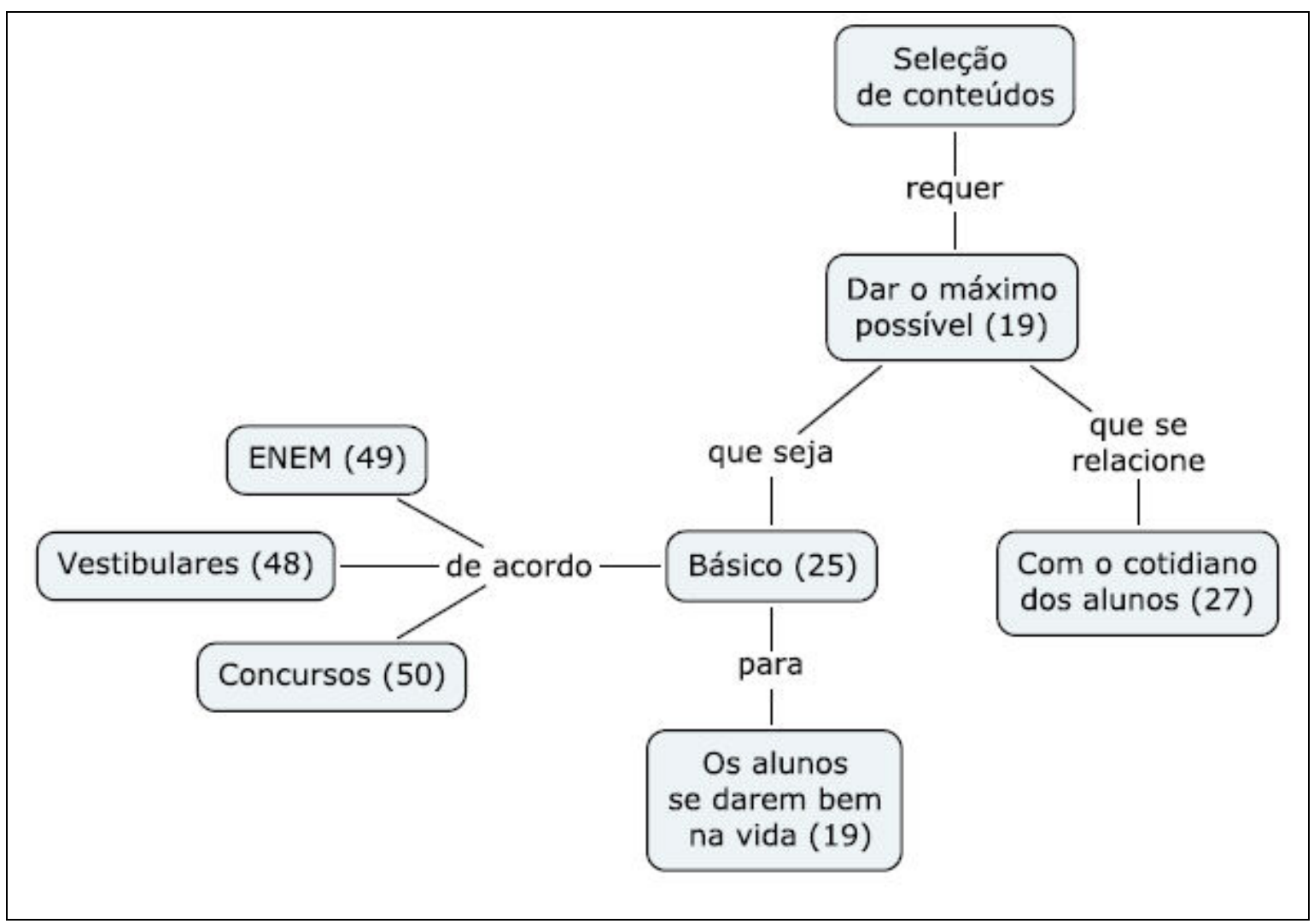

MC47. Plano de curso_seleção de conteúdos de P6

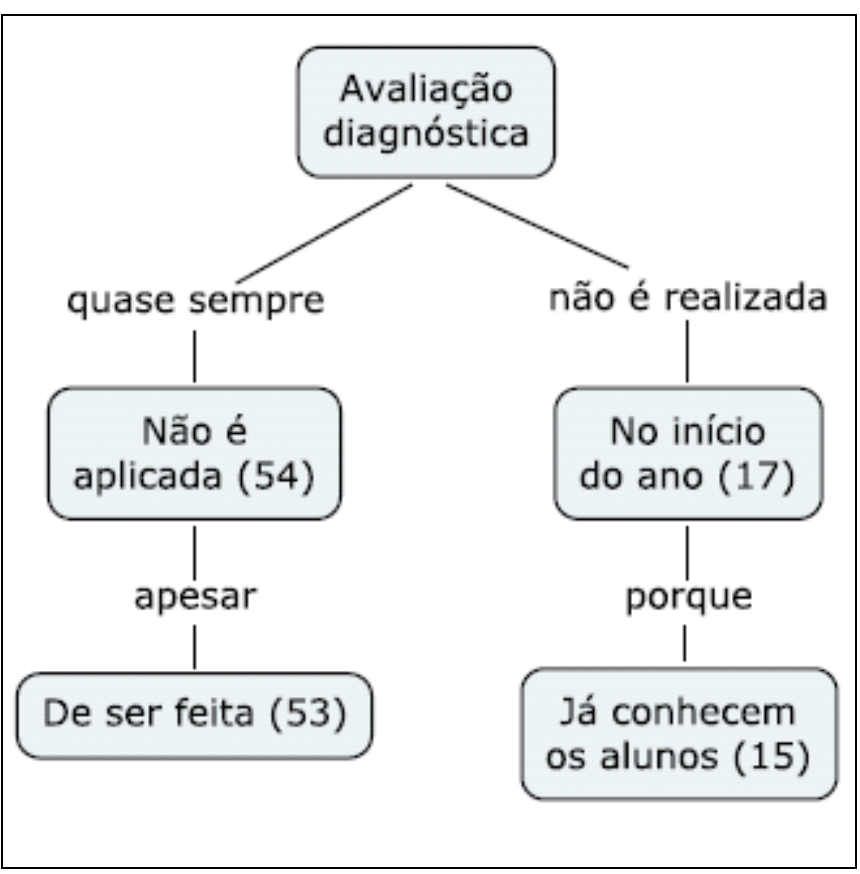

MC48. Plano de curso_avaliação diagnóstica de P6 
Para elaborar seu plano de curso P6 considera o conhecimento que já tem da clientela da escola, nós conhecemos nossos alunos, e também os recursos e o tempo disponível para poder ensinar.

Seu plano é organizado somente em conteúdos, pois considera que os objetivos e a metodologia são detalhes que o professor já sabe, é tão normal pra gente... A cada ano estes conteúdos são reorganizados dependendo do que foi cumprido no ano anterior.

P6 acredita que se deve dar o máximo possível para que eles consigam se dar bem na vida, pois só assim os alunos poderão ter uma profissão. Esses conteúdos devem relacionar-se com o cotidiano do aluno, porém são os que propõem os vestibulares, concursos e o ENEM.

Apesar de P6 fazer um diagnóstico da turma, esse não é utilizado no momento do planejamento porque não é realizado no início do ano. Nesse momento, é feita apenas uma revisão do que eles teriam que ter visto na $8^{a}$ série e que muitos não viram. Para nós não ficou claro em que momento é feita a avaliação diagnóstica e com que objetivo.

\section{Os planos de curso pré e pós-projeto}

\section{Planejamento Anual de Química - Ensino Médio - 2005}

\section{CONTEÚdOS OBJETIVOS}

Matéria e sua propriedadesEntender a estrutura geral de um sistema químico, tanto do ponto de vista macroscópico como do microscópico.

Estados físicos Reconhecer macroscopicamente os três estados da matéria associando suas características com modelos microscópicos.

Associar o aquecimento ou a retirada de energia com as mudanças de estado físico.

Fenômenos físicos e químicos Mostrar como a energia (principalmente térmica) pode interferir no estado físico das substâncias (fenômenos físicos) e como haver reações entre substâncias (fenômenos químicos).

Classificação da matéria Definir misturas e, por decorrência, o conceito de fases de um sistema. 
Relacionar as fases de um sistema às misturas homogêneas e heterogêneas e conceituá-las.

Separação de misturas Mostrar os métodos de separação de misturas, evidenciar sua importância na vida cotidiana e suas aplicações nos processos industriais mais importantes.

Constituição da matéria Entender o conceito de modelo atômico e sua evolução histórica.

Modelos atômicos

Caracterizar os modelos atômicos de Dalton, Thomson, Rutherford-Bohr, Bohr e Sommerfield e estabelecer comparações entre eles.

Reconhecer que o conceito de elemento químico diz respeito ao número atômico independentemente de a espécie considerada possuir ou não carga elétrica. Representar, de acordo com as regras da IUPAC, um átomo qualquer com base no seu símbolo e nas seguintes grandezas: número de massa e número atômico.

Identificar a ocorrência das principais semelhanças atomicas: isótopos, isóbaros e isótonos.

Diagrama de Linus Pauling Distribuir os elétrons dos átomos em subníveis e níveis de energia.

Tabela periódica Reconhecer que o modo como os elementos químicos estão Famíla e período agrupados na tabela periódica nos permite prever como algumas de propriedades variam nos grupos e nos períodos.

Obter dados a respeito dos elementos químicos por meio da utilização da tabela periódica.

Reconhecer as principais diferenças entre metais e nãometais.

Propriedades periódicas e aperiódicas Analisar as propriedades periódicas e aperiódicas, quanto a sua importância na Química.

Ligações químicas Regra do Octeto
Apresentação dos átomos estáveis.

Compreender a teoria do octeto.

Reconhecer que as ligações químicas se estabelecem 
pela união entre átomos por meio da interação dos elétrons da camada de valência.

Ligação iônica ou eletrovalente, Prever o tipo de ligação formada pela covalente ou molecular, distribuição eletrônica dos átomos ligantes e por suas covalente dativa ou posições na tabela. Análise e estudo das diversas coordenada formas de ligação fazendo a diferenciação entre e metálica a iônica, covalente e metálica.

Forças intermoleculares Prever a natureza polar ou apolar das ligações químicas.

Determinar a natureza polar ou apolar das moléculas relacionando-a à solubilidade e às forças intermoleculares.

Funções inorgânicas Desenvolver a noção de equação química e reconhecer as principais funções inorgânicas: ácidos, bases, sais e óxidos, através da identificação de suas propriedades funcionais

Ácido, base, sal e óxido Classificar os ácidos quanto a sua força.

Classificar as bases quanto a sua força.

Conhecer aplicações das principais substâncias e suas implicações tecnológicas, econômicas, sociais e ambientais.

Avaliar o papel dos óxidos na poluição atmosférica e no fenômeno do aquecimento global.

Classificar os óxidos em ácidos, básicos ou neutros.

Reações químicas

Desenvolver os conceitos de reação química e de equação química.

Identificar os principais tipos de reações químicas inorgânicas: síntese, decomposição, deslocamento e dupla-troca.

Representar por equações químicas as reações de neutralização ácido-base.

Prever a ocorrência das reações de deslocamento e dupla-troca.

Estabelecer o equilíbrio entre reagentes e produtos 
através do balanceamento das reações químicas.

Verificar que podem ser feitas relações entre quantidades.

Aspectos quantitativos da química Interpretar de forma mais quantitativa o significado das fórmulas e de uma equação química.

Relações de massa e conceito de mol Entender os conceitos de massa atômica, Massa molecular e mol.

Compreender a passagem do campo microscópico (massa atômica) para o macroscópico (massa molar). Aplicar o conceito de mol como princípio unificador para a resolução dos diferentes problemas que envolvem estequiometria.

Entender relações entre coeficientes da equação química e quantidades envolvidas na transformação. Treinar cálculos de fórmulas porcentual, mínima e molecular.

Gases

Gás Ideal

Transformações gasosas

Equação de Clapeyron

Lei de Avogadro

Soluções
Desenvolver o conceito de estado gasoso.

Identificar as variáveis de estado: pressão volume e temperatura.

Verificar que se pode relacionar as três variáveis de estado para uma mesma mostra de gás.

Desenvolver as principais propriedades e transformações gasosas de proporcionalidade.

Analisar, por meio de gráficos e tabelas, as transformações isotérmica, isobárica e isovolumétrica. Aplicar a equação geral dos gases e a equação de estado na resolução de situações-problema.

Efetuar cálculos que permitam conclusões sobre o comportamento macroscópico dos materiais no estado gasoso.

Relacionar o conhecimento adquirido com questões ambientais de relevância, como o efeito estufa. Compreender o conceito de solubilidade.

Classificar uma solução em saturada, insaturada ou 


\begin{tabular}{|c|c|}
\hline & $\begin{array}{l}\text { Supersaturada com base na interpretação de gráfico } \\
\text { com curvas de solubilidade. }\end{array}$ \\
\hline Aspectos quantitativos & $\begin{array}{l}\text { Interpretar dados e calcular as concentrações de } \\
\text { soluções expressas em: massa/volume; massa/massa; } \\
\text { quantidade de matéria/volume; ppm. }\end{array}$ \\
\hline Propriedades coligativas & $\begin{array}{l}\text { Diferenciar solução, dispersão coloidal e suspensão. } \\
\text { Conhecer os princípios gerais dos efeitos coligativos. } \\
\text { Relacionar as propriedades dos colóides a fenômenos } \\
\text { da natureza e do cotidiano. }\end{array}$ \\
\hline Termoquímica & $\begin{array}{l}\text { Entender a classificação das transformações físicas e } \\
\text { químicas com relação ao calor trocado com o ambiente. }\end{array}$ \\
\hline Entalpia & $\begin{array}{l}\text { Conhecer o conceito de variação de entalpia. } \\
\text { Diferenciar reação exotérmica de reação endotérmica. }\end{array}$ \\
\hline Lei de Hess & $\begin{array}{l}\text { Calcular a variação de entalpia de reações por } \\
\text { intermédio de gráficos de energia, tabelas ou equações } \\
\text { termoquímicas. }\end{array}$ \\
\hline Cinética química & $\begin{array}{l}\text { Constatar que as partículas dos reagentes estão em } \\
\text { movimento contínuo e desordenado, e as reações } \\
\text { decorrem de suas colisões. } \\
\text { Representar graficamente dados das concentrações de } \\
\text { reagentes e/ou produtos de uma reação em função do } \\
\text { tempo, com base em valores tabelados dessas } \\
\text { grandezas. }\end{array}$ \\
\hline Teoria da colisão & $\begin{array}{l}\text { Estudar a teoria das colisões e relacioná-la com a } \\
\text { termoquímica. }\end{array}$ \\
\hline $\begin{array}{l}\text { Fatores que modificam } \\
\text { a rapidez das reações }\end{array}$ & $\begin{array}{l}\text { Reconhecer os principais fatores que modificam } \\
\text { a rapidez das reações. } \\
\text { Identificar num diagrama de energia de uma reação } \\
\text { Química aspectos como: catalisador, energia de } \\
\text { ativação, complexo ativado e variação de entalpia. } \\
\text { Analisar a influência das concentrações iniciais dos } \\
\text { reagentes na rapidez de uma reação pela expressão } \\
\text { matemática de lei da rapidez de reação. } \\
\text { Avaliar a influência da temperatura, do catalisador, da }\end{array}$ \\
\hline
\end{tabular}


superfície de contato e da concentração de reagentes nos processos químicos do cotidiano.

Equilíbrio químico Compreender o conceito de equilíbrio químico. Identificar o estado de equilíbrio por meio da análise de gráficos de concentração de reagentes e produtos em função do tempo.

Identificar os principais fatores que podem alterar um sistema químico em equilíbrio, com base na análise das equações que representam sistemas em equilíbrio, na análise de gráficos e em experimento prático.

Princípio de Lê Chatelier Entender o princípio de Lê Chatelier de deslocamento de equilíbrio.

Prever o sentido do deslocamento de um equilíbrio químico aplicando o princípio de Lê Chatelier. Calcular os valores de constantes de equilíbrio, com base em dados de concentração e vice-versa.

Relacionar o significado do valor da constante de equilíbrio à determinação da posição do equilíbrio químico ou ao rendimento da reação.

Lei da diluição de Ostwald Escrever a equação de dissociação de ácidos e bases e a correspondente expressão da constante de equilíbrio.

Produto iônico da água e $\mathrm{pH}$ Conhecer os conceitos de $\mathrm{pH}$ e pOH.

Classificar um sistema em ácido, neutro ou básico, comparando o valor de seu $\mathrm{pH}$ com a escala de $\mathrm{pH}$.

\section{Eletroquímica} Determinar o estado de oxidação dos elementos com base em fórmulas químicas.

Entender a oxirredução como uma transferência de elétrons.

Identificar as reações de oxirredução, destacando os agentes oxidante e redutor.

Pilha de Daniell

Analisar um experimento sobre a reação do zinco metálico e uma solução aquosa de sulfato de cobre II. Representar as semi-reações anódicas, catódicas e a reação global de uma pilha pela linguagem simbólica e 
pelas notações químicas esquemáticas conforme a convenção da IUPAC, identificando o pólo negativo e o positivo da pilha.

Voltagem da pilha

Eletrólise

Galvanoplastia

Balanceamento

Radioatividade

Prever a possibilidade de ocorrência de uma reação espontânea, de oxidação e redução, analisando o valor do potencial-padrão da pilha, obtido de dados de uma tabela de potenciais-padrão de redução.

Explicar os fatores envolvidos na corrosão do ferro e identificar as estratégias utilizadas para a proteção contra a corrosão.

Explicar, por meio de linguagem simbólica e/ou esquemas, a eletrólise ígnea de cloreto de sódio e a eletrólise de uma solução aquosa do referido sal, identificando os principais produtos obtidos.

Descrever, por meio da linguagem discursiva e da linguagem simbólica, a galvanoplastia ou eletrodeposição como um dos processos industriais de aplicação de eletrólise, destacando aspectos como proteção à corrosão e durabilidade do produto.

Treinar balanceamentos de equações simples de oxirredução.

Reconhecer que a radioatividade é um fenômeno nuclear.

Partículas alfa e beta e gama Conhecer os três principais tipos de emissões radioativos: alfa, beta e gama.

Lei de Soddy, Fajans Prever valores de números atômicos e de

e Russel massa dos isótopos formados nas emissões alfa e beta. Reconhecer no cotidiano algumas aplicações importantes da energia nuclear nas áreas de medicina, agricultura, arqueologia, nas usinas nucleares e na fabricação de armas nucleares.

Identificar os riscos do uso da energia nuclear.

Desintegração radioativa Conhecer o conceito de meia-vida.

Caracterizar a meia-vida dos isótopos radioativos. 


\begin{tabular}{|c|c|}
\hline Fenômenos radioativos & $\begin{array}{l}\text { Entender os princípios gerais da fissão e fusão } \\
\text { nucleares. }\end{array}$ \\
\hline Química orgânica & $\begin{array}{l}\text { Identificar a participação da química orgânica entre os } \\
\text { materiais que fazem parte do nosso cotidiano. } \\
\text { Caracterizar as principais diferenças entre os } \\
\text { compostos orgânicos e inorgânicos. }\end{array}$ \\
\hline Postulados de Kekulé & $\begin{array}{l}\text { Identificar um átomo de carbono de acordo com os } \\
\text { postulados de Kekulé. } \\
\text { Reconhecer a capacidade do elemento carbono de } \\
\text { formar cadeias. }\end{array}$ \\
\hline $\begin{array}{l}\text { Classificação dos átomos } \\
\text { de cadeias }\end{array}$ & $\begin{array}{l}\text { Classificar os átomos de carbono em uma cadeia, } \\
\text { quanto ao número de carbonos ligados a eles. }\end{array}$ \\
\hline Classificação de cadeias & $\begin{array}{l}\text { Classificar as cadeias carbônicas quanto à disposição } \\
\text { dos átomos de carbono, quanto à ligação entre os } \\
\text { átomos de carbono e quanto à natureza dos átomos que } \\
\text { compõem a cadeia. } \\
\text { Formular e interpretar fórmulas estruturais planas e } \\
\text { simplificadas dos compostos de carbono. }\end{array}$ \\
\hline Funções orgânicas & Definir função orgânica. \\
\hline Hidrocarbonetos & $\begin{array}{l}\text { Reconhecer que o petróleo é uma mistura de } \\
\text { hidrocarbonetos que são separados em frações por } \\
\text { meio da destilação fracionada. } \\
\text { Reconhecer a importância do petróleo como fonte de } \\
\text { energia e matéria-prima para a fabricação de vários } \\
\text { materiais. } \\
\text { Formular e nomear os principais hidrocarbonetos } \\
\text { usando a nomenclatura usual e a recomendada pela } \\
\text { IUPAC. }\end{array}$ \\
\hline Funções oxigenadas & $\begin{array}{l}\text { Conceituar álcool, enol, fenol, aldeído, cetona, ácido } \\
\text { carboxílico, sal de ácido carboxílico, éster e éter. } \\
\text { Reconhecer fórmulas representativas das funções } \\
\text { citadas acima. } \\
\text { Reconhecer os principais usos e aplicações das } \\
\text { substâncias metanol, etanol, metanal, etanal, }\end{array}$ \\
\hline
\end{tabular}


propanona, etoxietano, ácido metanóico, ácido etnóico e etanoato de etila.

Funções nitrogenadas $\quad$ Reconhecer fórmulas representativas das funções: amina, amida, nitrila e nitrocomposto.

Haleto orgânico Identificar haleto orgânico.

Reconhecer em uma molécula de função mista as principais funções orgânicas.

\section{Isomeria}

Conceituar isomeria.

Plana

Identificar os tipos de isômeros planos: função, cadeia, posição e metameria.

Escrever, com base na fórmula molecular e no nome, as fórmulas estruturais dos possíveis isômeros de uma dada substância.

Espacial Identificar os tipos de isomeria espacial: geométrica e óptica.

\section{Reações Orgânicas}

Dispor as equações de algumas reações importantes dos hidrocarbonetos: combustão, substituição e adição. Dispor as equações de algumas reações importantes dos álcoois: combustão, desidratação, oxidação e esterificação.

Dispor as equações de algumas reações importantes dos ácidos carboxílicos: esterificação e neutralização. Reconhecer a importância dessas reações nos processos de transformação das matérias-primas.

\section{Polímeros} Identificar um polímero.

Classificação

Classificar os polímeros em naturais ou sintéticos.

Compreender a importância dos polímeros em nosso dia-a-dia.

Reconhecer as fórmulas representativas de aminoácidos e que as proteínas são formadas por grupamentos de aminoácidos, unidos entre si, por ligações peptídicas.

Reconhecer que os polímeros naturais, como glicogênio, celulose e amido, são formados por 
moléculas de glicose.

Reconhecer os polímeros artificiais de adição, como o polietileno, PVC, teflon, poliestireno, e os de condensação, como o náilon e o dácron.

\section{Planejamento de Química - 2006 Ensino Médio}

\section{CONTEÚDOS OBJETIVOS}

Matéria e sua propriedadesEntender a estrutura geral de um sistema químico, tanto do ponto de vista macroscópico como do microscópico.

Estados físicos Reconhecer macroscopicamente os três estados da matéria associando suas características com modelos microscópicos.

Associar o aquecimento ou a retirada de energia com as mudanças de estado físico.

Fenômenos físicos

Mostrar como a energia (principalmente térmica) e químicos pode interferir no estado físico das substâncias

(fenômenos físicos) e como haver reações entre substâncias (fenômenos químicos).

Classificação da matéria Definir misturas e, por decorrência, o conceito de fases de um sistema.

Relacionar as fases de um sistema às misturas homogêneas e heterogêneas e conceituá-las.

Separação de misturas $\quad$ Mostrar os métodos de separação de misturas, evidenciar sua importância na vida cotidiana e suas aplicações nos processos industriais mais importantes.

Constituição da matéria Entender o conceito de modelo atômico e sua evolução 
Modelos atômicos

Diagrama Energético

\section{Tabela periódica}

Família e período

Propriedades periódicas e aperiódicas

\section{Ligações químicas}

Regra do octeto histórica.

Caracterizar os modelos atômicos de Dalton, Thomson, Rutherford-Bohr, Bohr e Sommerfield e estabelecer comparações entre eles.

Reconhecer que o conceito de elemento químico diz respeito ao número atômico independentemente de a espécie considerada possuir ou não carga elétrica. Representar, de acordo com as regras da IUPAC, um átomo qualquer com base no seu símbolo e nas seguintes grandezas: número de massa e número atômico. Identificar a ocorrência das principais semelhanças atomicas: isótopos, isóbaros e isótonos.

Distribuir os elétrons dos átomos em subníveis e níveis de energia.

Reconhecer que o modo como os elementos químicos estão agrupados na tabela periódica nos permite prever como algumas de suas propriedades variam nos grupos e nos períodos.

Obter dados a respeito dos elementos químicos por meio da utilização da tabela periódica.

Reconhecer as principais diferenças entre metais e nãometais.

Analisar as propriedades periódicas e aperiódicas, quanto a sua importância na Química.

Apresentação dos átomos estáveis.

Compreender a teoria do octeto.

Reconhecer que as ligações químicas se estabelecem pela união entre átomos por meio da interação dos elétrons da camada de valência.

Ligação iônica ou eletrovalente, Prever o tipo de ligação formada pela covalente ou molecular, distribuição eletrônica dos átomos ligantes e por suas covalente dativa ou posições na tabela. 
coordenada e metálica

intermoleculares

\section{Funções inorgânicas}

Ácido, base, sal e óxido
Análise e estudo das diversas formas de ligação fazendo a diferenciação entre a iônica, covalente e metálica.

Prever a natureza polar ou apolar das ligações químicas.

Determinar a natureza polar ou apolar das moléculas relacionado-a à solubilidade $\mathrm{e}$ às forças intermoleculares.

Desenvolver a noção de equação química e reconhecer as principais funções inorgânicas: ácidos, bases, sais e óxidos, através da identificação de sua propriedades funcionais.

Classificar os ácidos quanto a sua força.

Classificar as bases quanto a sua força.

Conhecer aplicações das principais substâncias e suas implicações tecnológicas, econômicas, sociais e ambientais.

Avaliar o papel do óxidos na poluição atmosférica e no fenômeno do aquecimento global.

Classificar os óxidos em ácidos, básicos ou neutros.

Reações químicas Desenvolver os conceitos de reação química e de equação química.

Identificar os principais tipos de reações químicas inorgânicas: síntese, decomposição, deslocamento e duplatroca.

Representar por equações químicas as reações de neutralização ácido-base

Prever a ocorrência das reações de deslocamento e dupla-troca.

Estabelecer o equilíbrio entre reagentes e produtos através do balanceamento das reações químicas.

Verificar que podem ser feitas relações entre quantidades.

Aspectos quantitativos da Interpretar de forma mais quantitativa o significado das 


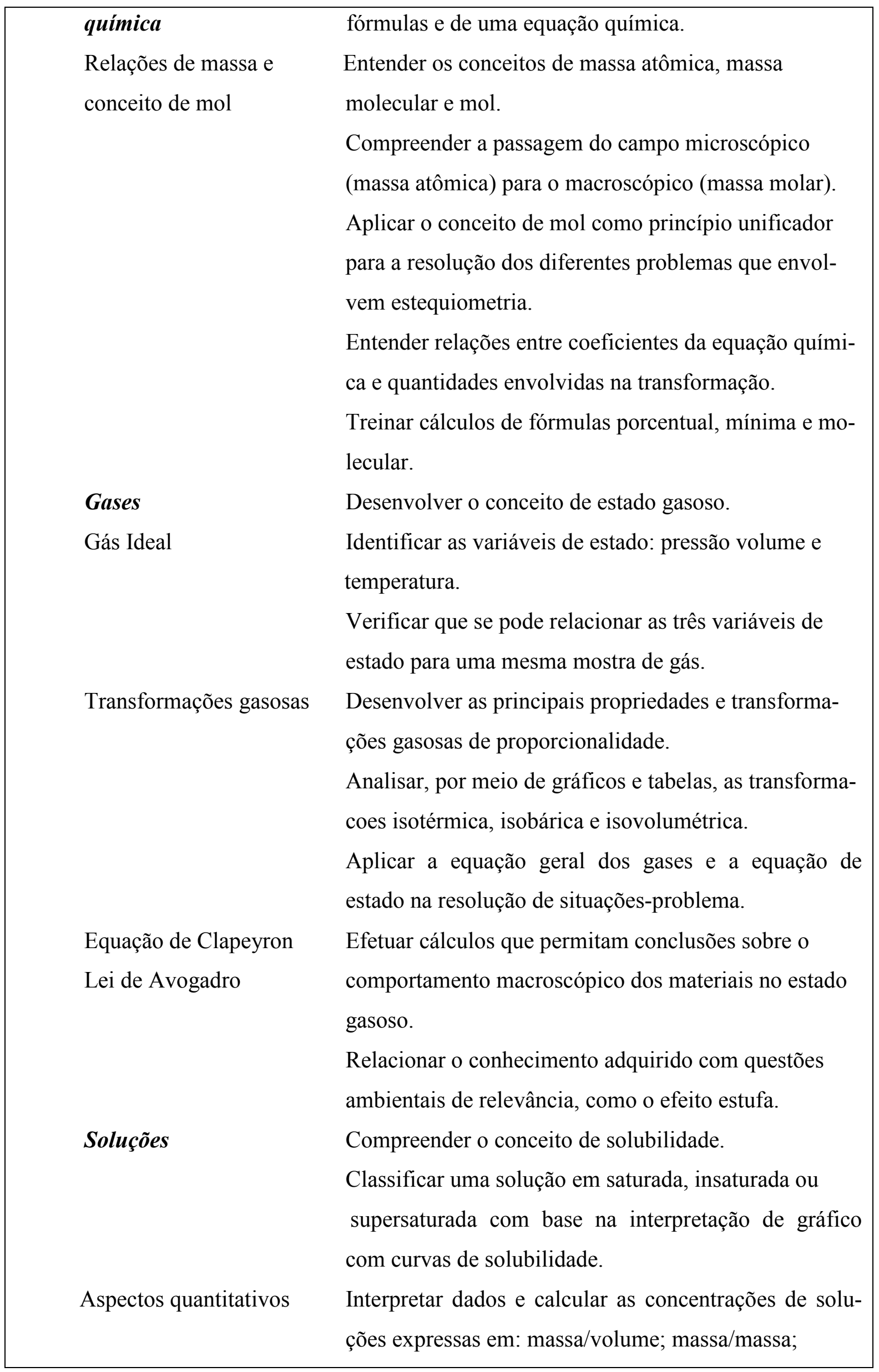




\begin{tabular}{|c|c|}
\hline & quantidade de matéria/volume; ppm. \\
\hline & Diferenciar solução, dispersão coloidal e suspensão. \\
\hline \multirow[t]{3}{*}{ Propriedades coligativas } & Conhecer os princípios gerais dos efeitos coligativos. \\
\hline & Relacionar as propriedades dos colóides a fenômenos \\
\hline & da natureza e do cotidiano. \\
\hline \multirow[t]{2}{*}{ Termoquímica } & Entender a classificação das transformações físicas e \\
\hline & químicas com relação ao calor trocado com o ambiente. \\
\hline \multirow[t]{2}{*}{ Entalpia } & Conhecer o conceito de variação de entalpia. \\
\hline & Diferenciar reação exotérmica de reação endotérmica. \\
\hline \multirow[t]{2}{*}{ Lei de Hess } & Calcular a variação de entalpia de reações por intermé- \\
\hline & $\begin{array}{l}\text { dio de gráficos de energia, tabelas ou equações termo- } \\
\text { químicas. }\end{array}$ \\
\hline \multirow[t]{6}{*}{ Cinética química } & Constatar que as partículas dos reagentes estão em \\
\hline & $\begin{array}{l}\text { movimento contínuo e desordenado, e as reações de- } \\
\text { correm de suas colisões. }\end{array}$ \\
\hline & Representar graficamente dados das concentração de \\
\hline & reagentes e/ou produtos de uma reação em função do \\
\hline & tempo, com base em valores tabelados dessas grande- \\
\hline & 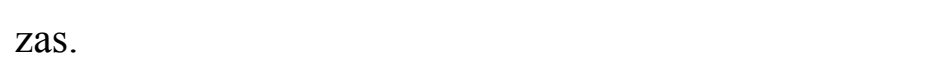 \\
\hline Teoria da colisão & $\begin{array}{l}\text { Estudar a teoria das colisões e relacioná-la com a ter- } \\
\text { moquímica. }\end{array}$ \\
\hline \multirow{11}{*}{$\begin{array}{l}\text { Fatores que modificam a } \\
\text { rapidez das reações }\end{array}$} & Reconhecer os principais fatores que modificam a rapi- \\
\hline & dez das reações. \\
\hline & Identificar num diagrama de energia de uma reação \\
\hline & química aspectos como: catalisador, energia de ativa- \\
\hline & ção, complexo ativado e variação de entalpia. Analisar \\
\hline & a influência das concentrações iniciais dos reagentes na \\
\hline & rapidez de uma reação pela expressão matemática de \\
\hline & lei da rapidez de reação. Avaliar a influência da \\
\hline & temperatura, do catalisador, da superfície de contato e \\
\hline & da concentração de reagentes nos processos químicos \\
\hline & do cotidiano. \\
\hline \multirow[t]{2}{*}{ Equilíbrio químico } & Compreender o conceito de equilíbrio químico. \\
\hline & Identificar o estado de equilíbrio por meio da análise de \\
\hline
\end{tabular}


gráficos de concentração de reagentes e produtos em função do tempo.

Identificar os principais fatores que podem alterar um sistema químico em equilíbrio, com base na análise das equações que representam sistemas em equilíbrio, na análise de gráficos e em experimento prático.

Princípio de Lê Chatelier Entender o princípio de Lê Chatelier de deslocamento de equilíbrio.

Prever o sentido do deslocamento de um equilíbrio químico aplicando o princípio de Lê Chatelier.

Calcular os valores de constantes de equilíbrio, com base em dados de concentração e vice-versa.

Relacionar o significado do valor da constante de equilíbrio à determinação da posição do equilíbrio químico ou ao rendimento da reação.

Lei da diluição de Ostwald Escrever a equação de dissociação de ácidos e bases e a correspondente expressão da constante de equilíbrio.

Produto iônico da água e $\mathrm{pH}$ Conhecer os conceitos de $\mathrm{pH}$ e $\mathrm{pOH}$.

Classificar um sistema em ácido, neutro ou básico, comparando o valor de seu $\mathrm{pH}$ com a escala de $\mathrm{pH}$.

Eletroquímica Determinar o estado de oxidação dos elementos com base em fórmulas químicas.

Entender a oxirredução como uma transferência de eletrons.

Identificar as reações de oxirredução, destacando os agentes oxidante e redutor.

Pilha de Daniell

Analisar um experimento sobre a reação do zinco metalico e uma solução aquosa de sulfato de cobre II.

Representar as semi-reações anódicas, catódicas e a reação global de uma pilha pela linguagem simbólica e pelas notações químicas esquemáticas conforme a convenção da IUPAC, identificando o pólo negativo e o positivo da pilha. Voltagem da pilha. Prever a 
possibilidade de ocorrência de uma reação espontânea, de oxidação e redução, analisando o valor do potencial-padrão da pilha, obtido de dados de uma tabela de potenciais-padrão de redução.

Explicar os fatores envolvidos na corrosão do ferro e identificar as estratégias utilizadas para a proteção contra a corrosão.

Eletrólise

Galvanoplastia

Balanceamento

Radioatividade

Partículas alfa e beta e radiação gama

Explicar, por meio de linguagem simbólica e/ou esquemas, a eletrólise ígnea de cloreto de sódio e a eletrólise de uma solução aquosa do referido sal, identificando os principais produtos obtidos.

Descrever, por meio da linguagem discursiva e da linguagem simbólica, a galvanoplastia ou eletrodeposição como um dos processos industriais de aplicação de eletrólise, destacando aspectos como proteção à corrosão e durabilidade do produto.

Treinar balanceamentos de equações simples de oxirredução.

Reconhecer que a radioatividade é um fenômeno nuclear.

Conhecer os três principais tipos de emissões radioativos: alfa, beta e gama.

Lei de Soddy, Fajans e Russel

Prever valores de números atômicos e de massa dos isótopos formados nas emissões alfa e beta. Reconhecer no cotidiano algumas aplicações importantes da energia nuclear nas áreas de medicina, agricultura, arqueologia, nas usinas nucleares e na fabricação de armas nucleares.

Identificar os riscos do uso da energia nuclear.

Desintegração radioativa Conhecer o conceito de meia-vida.

Caracterizar a meia-vida dos isótopos radioativos.

Fenômenos radioativos Entender os princípios gerais da fissão e fusão nucleares.

Química orgânica Identificar a participação da química orgânica entre os 
materiais que fazem parte do nosso cotidiano.

Caracterizar as principais diferenças entre os compostos orgânicos e inorgânicos.

Postulados de Kekulé Identificar um átomo de carbono de acordo com os postulados de Kekulé.

Reconhecer a capacidade do elemento carbono de formar cadeias.

Classificação dos átomos de Classificar os átomos de carbono em uma cadeia, carbono quanto ao número de carbonos ligados a eles.

Classificação de cadeias Classificar as cadeias carbônicas quanto à disposição carbônicas dos átomos de carbono, quanto à ligação entre os atomos de carbono e quanto à natureza dos átomos que compõem a cadeia.

Formular e interpretar fórmulas estruturais planas e simplificadas dos compostos de carbono.

\section{Funções orgânicas}

Definir função orgânica.

Hidrocarbonetos

Reconhecer que o petróleo é uma mistura de hidrocarbonetos que são separados em frações por meio da destilação fracionada.

Reconhecer a importância do petróleo como fonte de energia e matéria-prima para a fabricação de vários materiais

Formular e nomear os principais hidrocarbonetos usando a nomenclatura usual e a recomendada pela IUPAC.

Funções oxigenadas Conceituar álcool, enol, fenol, aldeído, cetona, ácido carboxílico, sal de ácido carboxílico, éster e éter.

Reconhecer fórmulas representativas das funções citadas acima.

Reconhecer os principais usos e aplicações das substâncias metanol, etanol, metanal, etanal, propanona, etoxietano, ácido metanóico, ácido etnóico e etanoato de etila.

Funções nitrogenadas $\quad$ Reconhecer fórmulas representativas das funções: amina, amida, nitrila e nitrocomposto. 


\begin{tabular}{|c|c|}
\hline Haleto orgânico & $\begin{array}{l}\text { Identificar haleto orgânico. } \\
\text { Reconhecer em uma molécula de função mista as prin- } \\
\text { cipais funções orgânicas. }\end{array}$ \\
\hline Isomeria & Conceituar isomeria. \\
\hline Plana & $\begin{array}{l}\text { Identificar os tipos de isômeros planos: função, cadeia, } \\
\text { posição e metameria. } \\
\text { Escrever, com base na fórmula molecular e no nome, } \\
\text { as fórmulas estruturais dos possíveis isômeros de uma } \\
\text { dada substância. }\end{array}$ \\
\hline Espacial & $\begin{array}{l}\text { Identificar os tipos de isomeria espacial: geométrica e } \\
\text { óptica. }\end{array}$ \\
\hline Reações Orgânicas & $\begin{array}{l}\text { Dispor as equações de algumas reações importantes } \\
\text { dos hidrocarbonetos: combustão, substituição e adição. } \\
\text { Dispor as equações de algumas reações importantes } \\
\text { dos álcoois: combustão, desidratação, oxidação e } \\
\text { esterifica ção. } \\
\text { Dispor as equações de algumas reações importantes } \\
\text { dos ácidos carboxílicos: esterificação e neutralização. } \\
\text { Reconhecer a importância dessas reações nos processos } \\
\text { de transformação das matérias-primas. }\end{array}$ \\
\hline Polímeros & Identificar um polímero. \\
\hline Classificação & $\begin{array}{l}\text { Classificar os polímeros em naturais ou sintéticos. } \\
\text { Compreender a importância dos polímeros em nosso } \\
\text { dia-a-dia. }\end{array}$ \\
\hline & $\begin{array}{l}\text { Reconhecer as fórmulas representativas de } \\
\text { aminoácidos e que as proteínas são formadas por } \\
\text { grupamentos de aminoácidos, unidos entre si, por } \\
\text { ligações peptídicas. }\end{array}$ \\
\hline & $\begin{array}{l}\text { Reconhecer que os polímeros naturais, como glicogê- } \\
\text { nio, celulose e amido, são formados por moléculas de } \\
\text { glicose. }\end{array}$ \\
\hline & $\begin{array}{l}\text { Reconhecer os polímeros artificiais de adição, como o } \\
\text { polietileno, PVC, teflon, poliestireno, e os de } \\
\text { condensação, como o náilon e o dácron. }\end{array}$ \\
\hline
\end{tabular}




\begin{tabular}{|lll|}
\hline \multicolumn{1}{|c|}{ ESTRATÉGIAS } & RECURSOS & AVALIAÇÃo \\
Aula expositiva. & Lousa e giz. & $\begin{array}{l}\text { Contínua e } \\
\text { paralela }\end{array}$ \\
& & $\begin{array}{l}\text { através de } \\
\text { Aula prática. }\end{array}$ \\
Resolução de exercícios. & Lateriais diversos de laboratório. & provas, \\
Projetos desenvolvidos no didico. & Sala de informática. & listas de exercí- \\
ano letivo. & Internet. & cios, discussões \\
& & e debates, \\
& & pesquisas e \\
& & participação \\
& & nos projetos. \\
\hline
\end{tabular}

Os planos de curso elaborados por P6 são para todo o Ensino Médio. Podem ser descritos como uma lista de conteúdos que normalmente se encontra no livro didático do professor. Como a escola adota livro didático acreditamos que seja a cópia dos conteúdos contidos nele.

Esse tipo de plano, se é que podemos chamar assim, está de acordo com a concepção de P6 sobre planejamento. Para ele o plano é importante para não se perder durante o ano e para padronizar o que é ensinado na escola.

Todo o conteúdo do ensino de Química está posto nesses planos porque o professor não consegue enxergar o que é mais importante, ...o mais importante pra um pode não ser pro outro.

A diferença dos planos de anos diferentes é que após o projeto P6 inseriu os tópicos: estratégias, recursos e avaliação. Nós questionamos sobre que tipo de avaliação é feita pelo professor já que ele não determina quais objetivos deseja alcançar. Um está condicionado ao outro. Se não sei onde quero chegar, o que vou avaliar?

Entendemos que esse tipo de plano não auxilia o professor em sua prática diária, devendo ser extremamente necessário um plano de aula. P6 diz que elabora esse plano pensando nos exercícios que irá dar em cada sala, ... vou fazer isso, vou fazer aquilo... e então é registrado no diário. 


\section{Dados do questionário pós-projeto}

Esse professor também conseguiu trabalhar com a proposta do projeto, mas nem todas as simulações que deveriam ser elaboradas pelos alunos estavam prontas ao final do ano.

Para organizar seu trabalho e assim saber passo-a-passo o que fazer, elaborou o plano de aulas e este foi modificado por causa do tempo previsto para as atividades.

\section{E. Discussão dos dados}

Apesar de P6 colocar que o planejamento é um norteador de seu trabalho não percebemos como esta lista de conteúdos pode auxiliá-lo em sua prática. Não vemos a necessidade de o professor copiar tudo isto de um livro didático para conseguir trabalhar. Basta consultá-lo quando necessário.

Também não percebemos como a realidade da clientela é considerada já que não se faz um diagnóstico das turmas e os planos são idênticos de um ano para o outro. Não há objetivos explicitados e, portanto, o professor não tem como direcionar seu trabalho. Esses dados são condizentes com um professor conteudista e tradicional em sua prática, com aulas expositivas e com o propósito de transmitir conhecimentos. 
4.2.7. Professor $P 7$

A. Dados sobre a concepção de planejamento

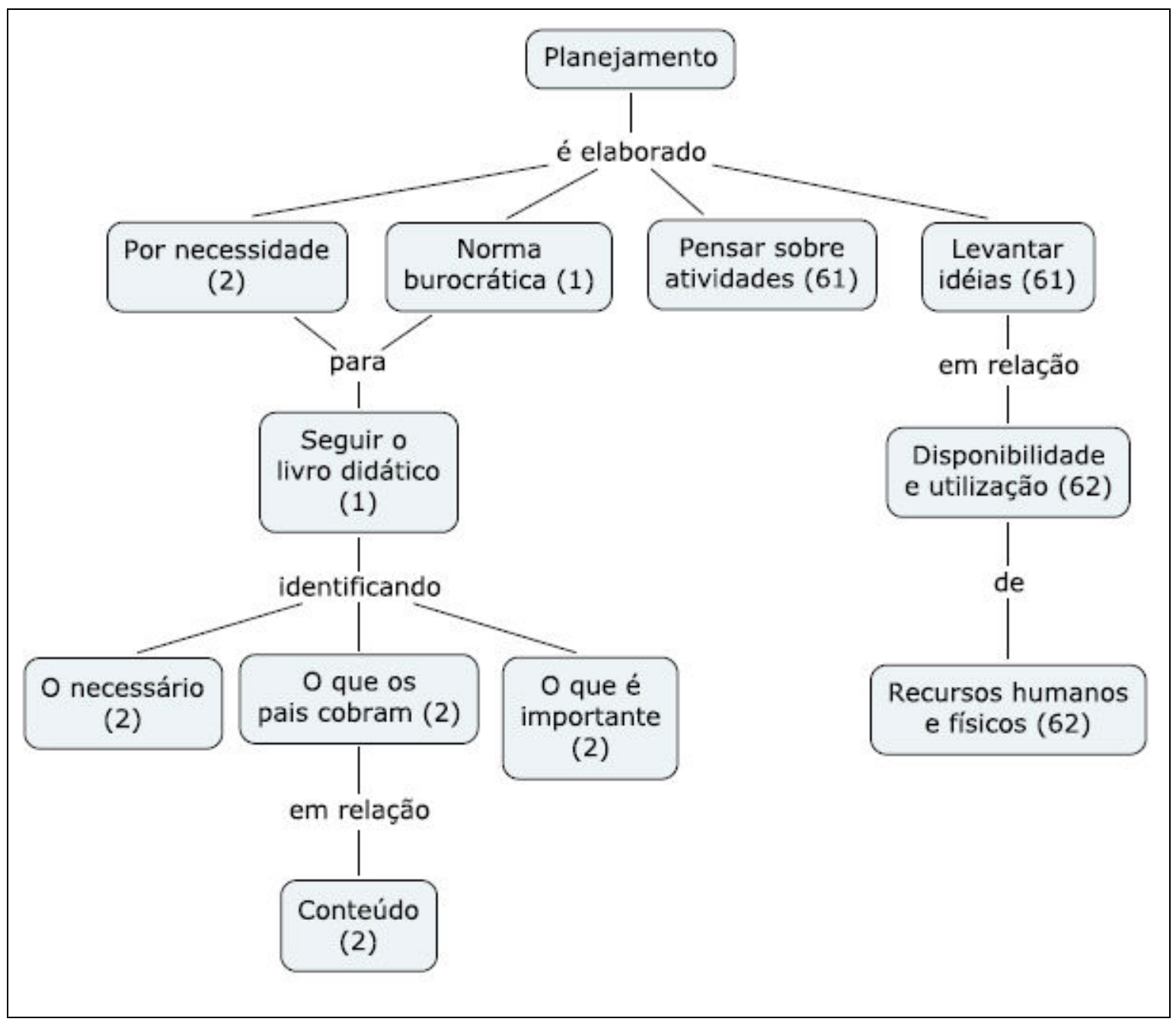

MC49. Planejamento_significado e finalidade de P7 


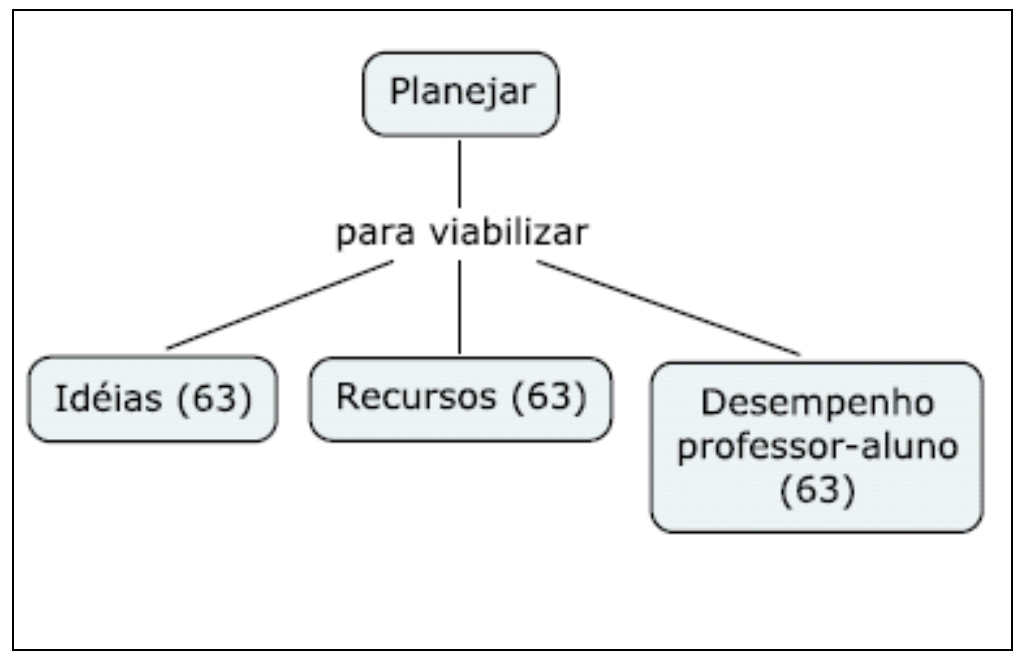

MC50. Planejamento_importância de P7

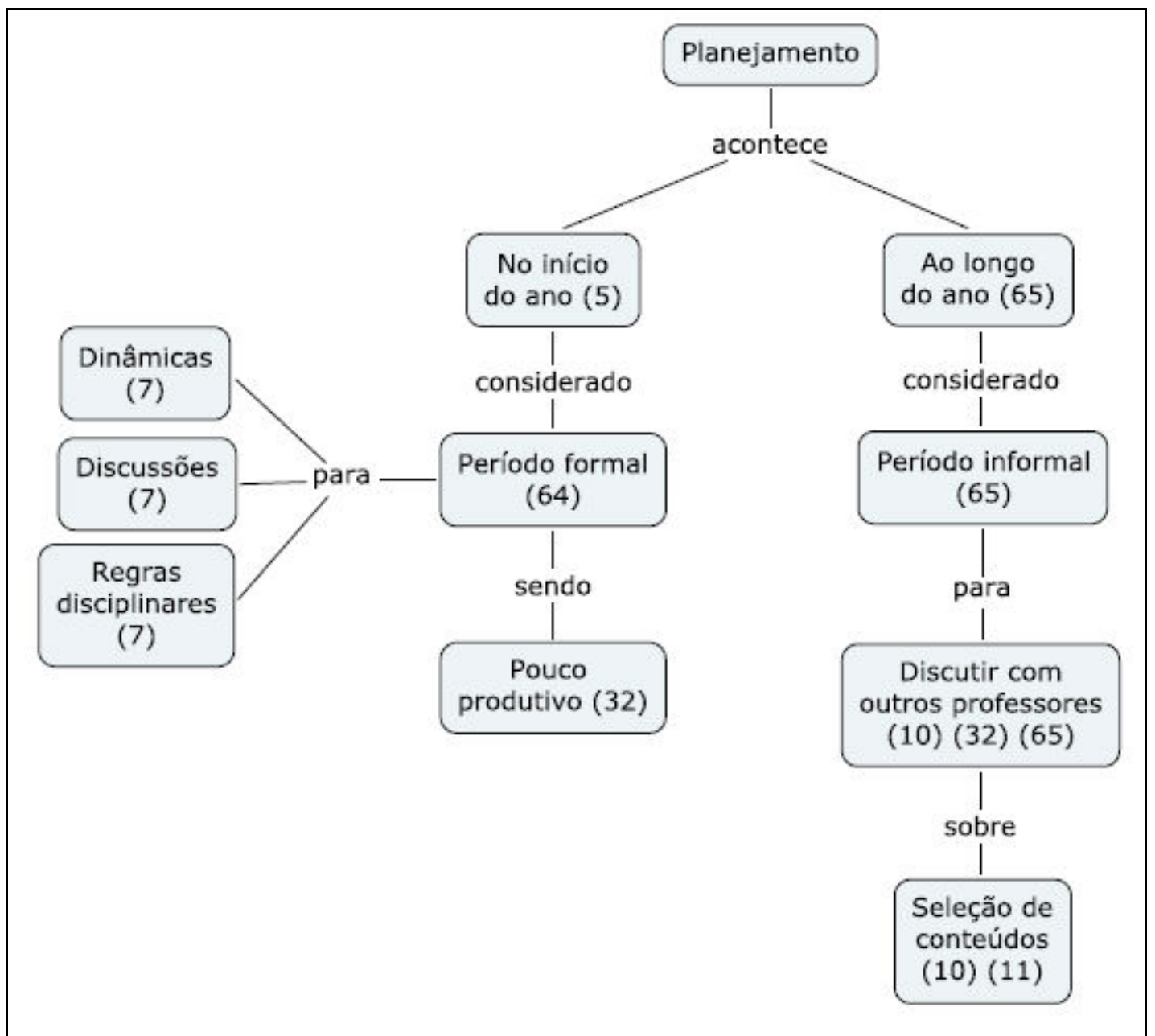

MC51. Planejamento_processo de P7 


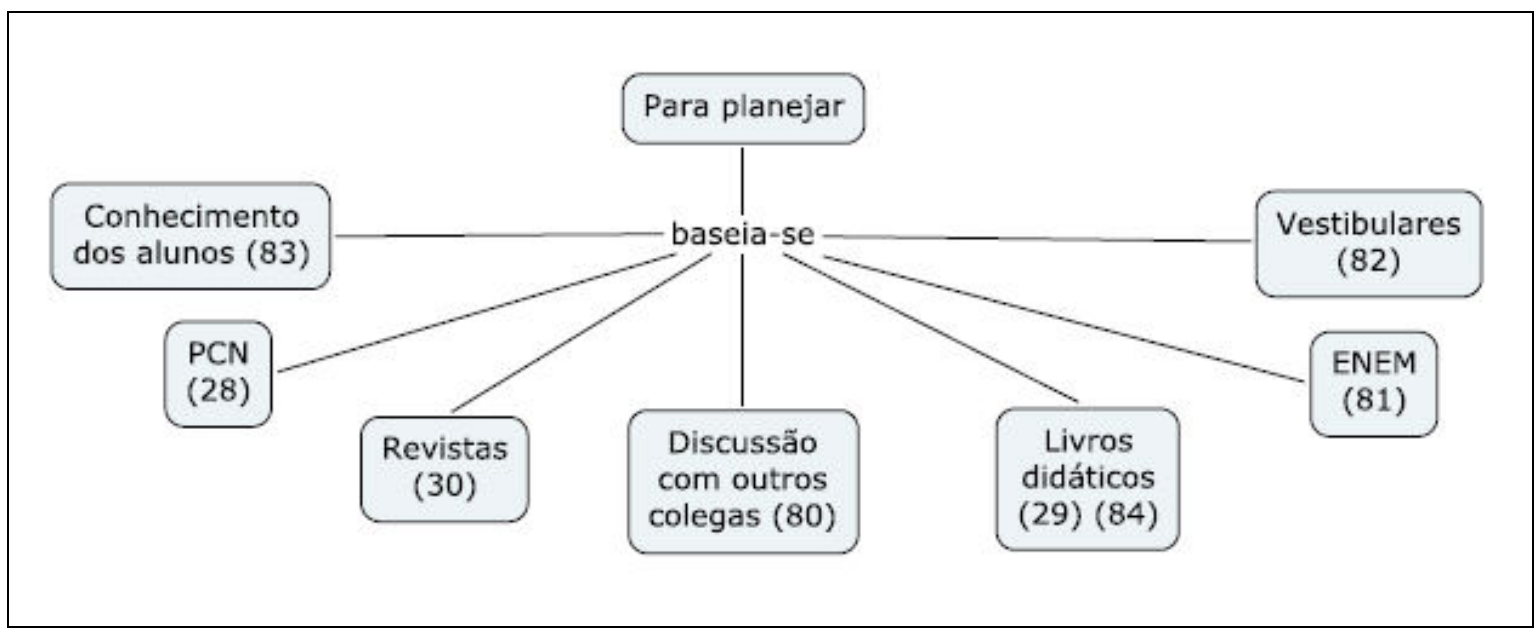

MC52. Planejamento_referências bibliográficas de P7

O planejamento para P7 é uma forma de pensar nos conteúdos que serão estudados no ano letivo e também nos recursos necessários para as aulas. Como sua escola adota livro didático, ele precisa prever quais conteúdos irá ensinar pensando no que é necessário para a turma e na cobrança dos pais e da escola. Tem coisas no livro que não são tão importantes e a gente tem que dar porque o pai cobra que aquela parte do livro não foi usada. Assim, ele é importante porque permite a viabilização das idéias, dos recursos e do desempenho professor-aluno.

O planejamento considerado formal acontece no início do ano em sua escola e não permite que os professores discutam suas disciplinas. Esse momento é dedicado a dinâmicas, discussões e assuntos gerais da escola e somente por uma hora é que os professores podem juntar-se para conversar sobre suas práticas. É claro que não é suficiente. P7 considera um planejamento informal as conversas que tem com os outros professores em momentos ao longo do ano e é partir destas conversas que organiza seu trabalho.

P7 utiliza como referências, além do livro didático adotado pela escola, os PCNs, e como recursos para as aulas, revistas como a Veja e a Nova Escola, informática e vídeos que fazem parte do acervo da escola. 


\section{B. Dados sobre a elaboração do plano de curso}

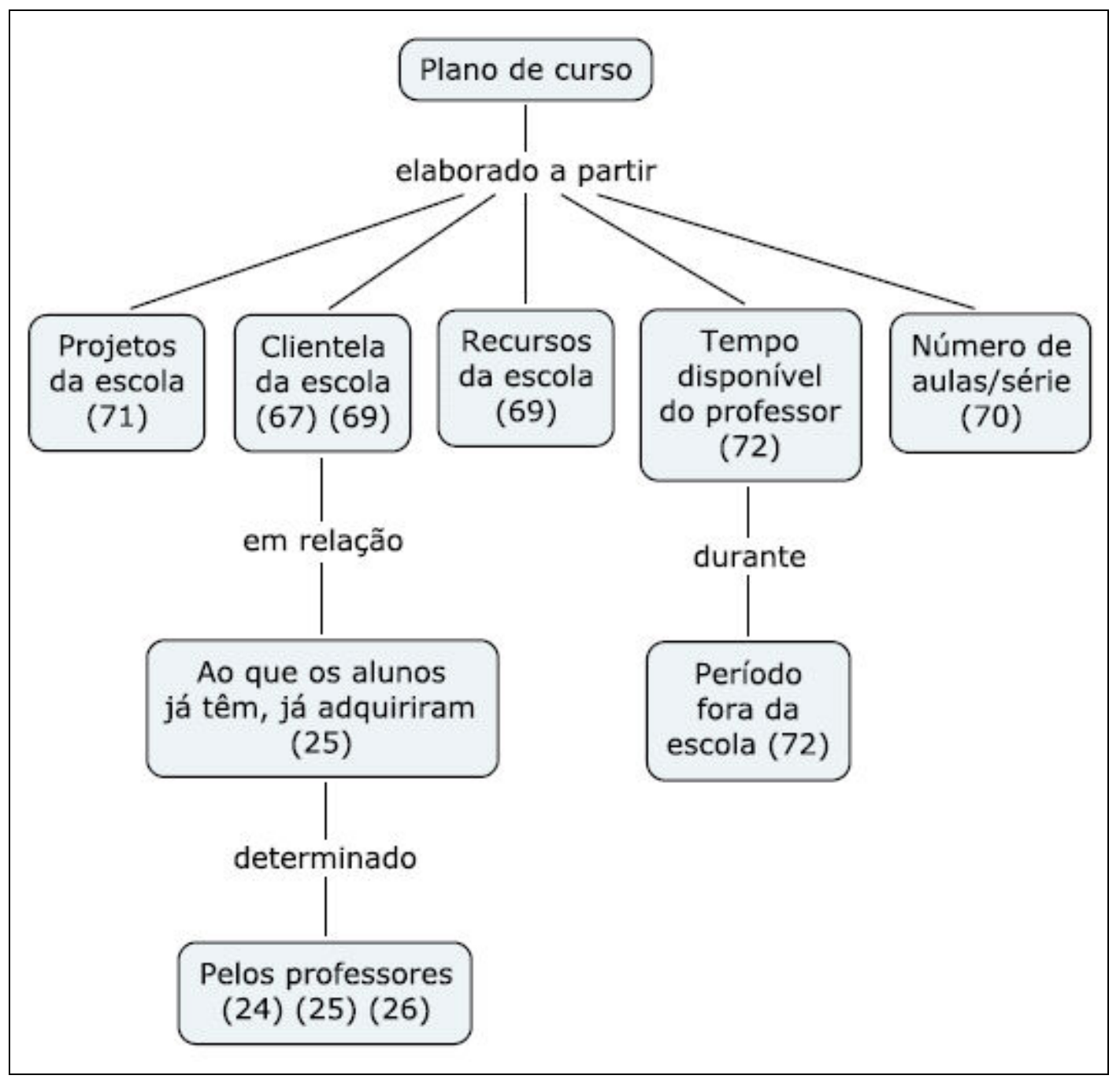

MC53. Plano de curso_pré-requisitos de P7 


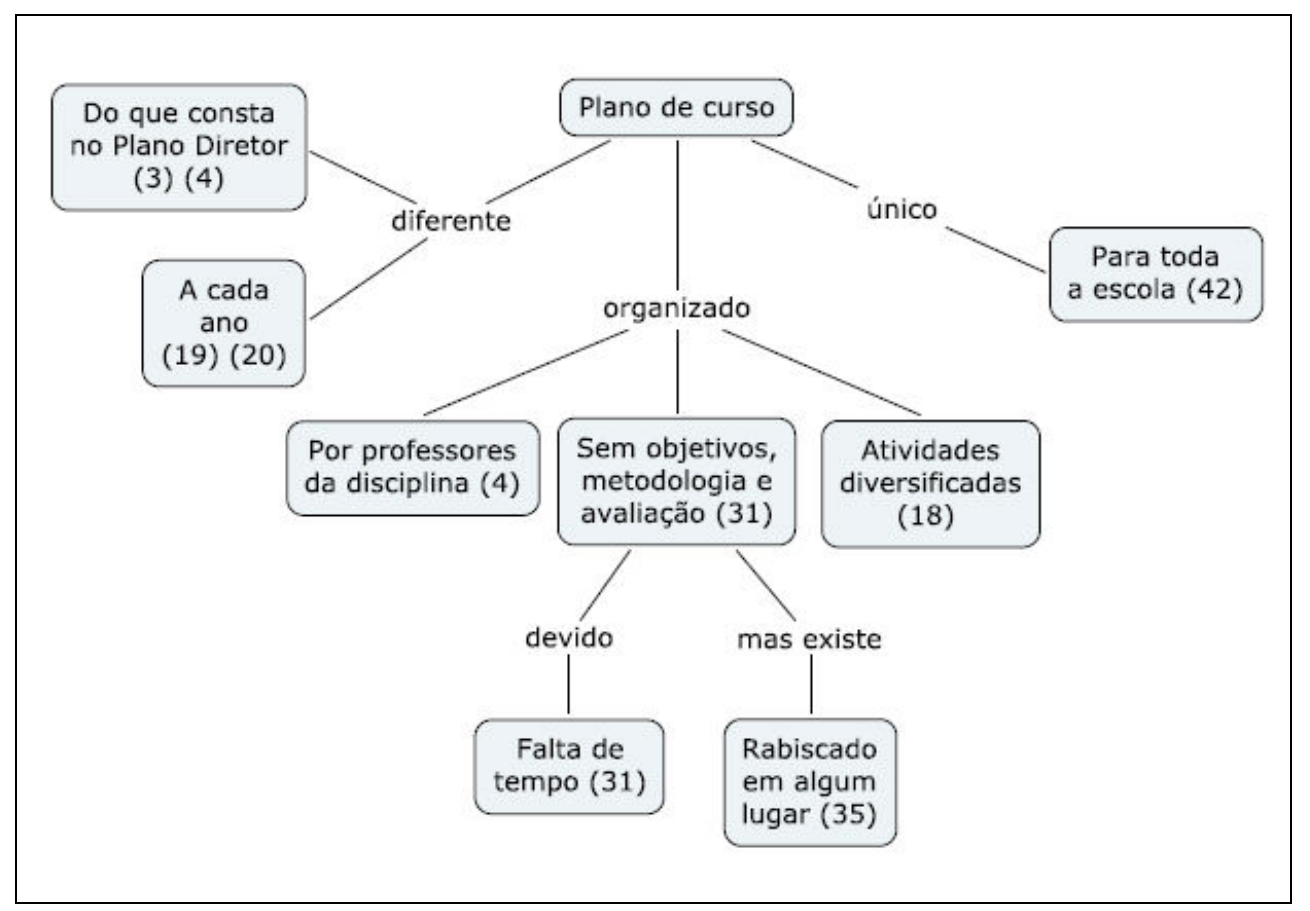

MC54. Plano de curso_características de P7

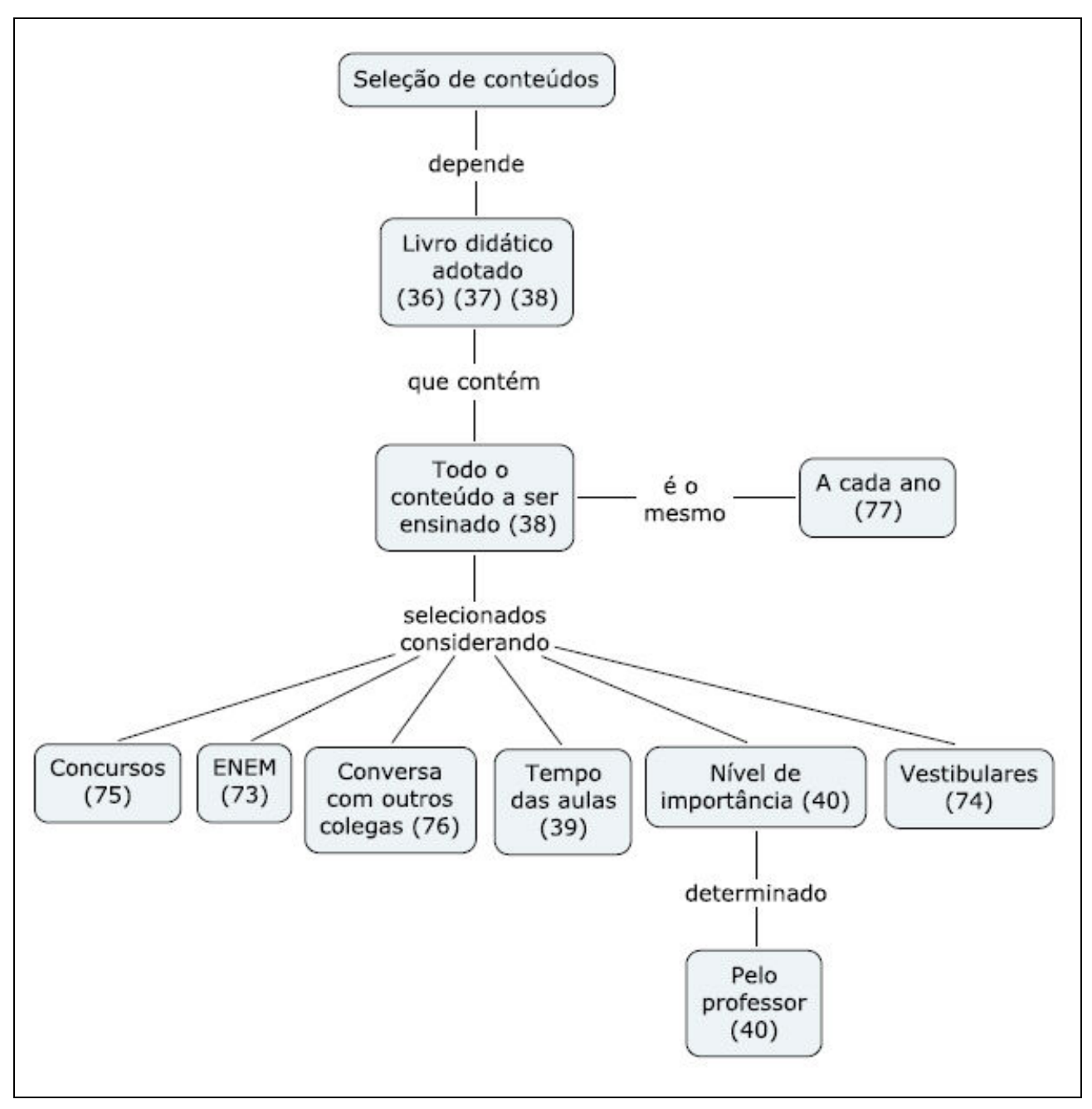

MC55. Plano de curso_seleção de conteúdos de P7 


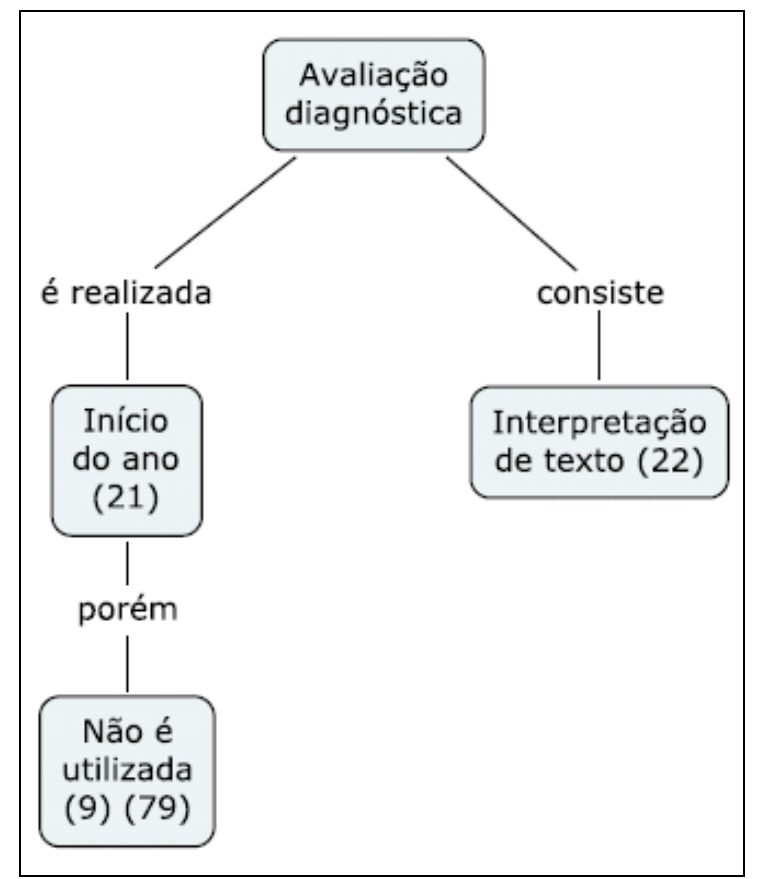

MC56. Plano de curso_avaliação diagnóstica de P7

Para elaborar seu plano de curso, P7 considera os projetos da escola, a clientela, os recursos disponíveis, o número de aulas e ainda a disponibilidade de meu tempo extra escola. Esse plano é único para toda a escola e é organizado por professores da mesma disciplina. Não constam objetivos, metodologia e avaliação por não ter tempo para pensar nisso, mas são tópicos que são pensados e tirados de livros quando os professores têm tempo de se reunir e alguma coisa rabiscada em algum lugar a gente tem.

Sendo assim, o plano de curso se resume aos conteúdos a serem estudados que são selecionados de acordo com o livro didático, com o nível de importância determinado pelo professor e com o tempo disponível para as aulas.

Apesar dos conteúdos serem únicos para toda a escola, a forma de trabalhá-los não é porque a produtividade de cada sala é diferente... o conteúdo é trabalhado de forma diferenciada... então, o exercício não é no mesmo nível de complexidade.

Para identificar esta diversidade, o professor prepara algumas questões baseadas em um texto, são atividades de interpretação que permitem diagnosticar o nível de conhecimento da sala. 


\section{Os planos de curso pré e pós-projeto}

Os planos de curso de P7 são os mesmos de P6, pois estes professores trabalham na mesma escola e elaboram juntos esses planos que valem para todos os períodos. Então, as considerações sobre os planos são as mesmas de P6.

Os planos também estão de acordo com as concepções de P7 na medida em que esse valoriza o cumprimento do livro didático. Então, todo o conteúdo do ensino de Química está proposto nos planos porque o professor tem que seguir essa norma burocrática da escola... eu tenho que seguir o livro.

\section{Dados do questionário pós-projeto}

O professor diz ter trabalhado com a proposta do LabVirt mas não conseguiu enviar suas simulações por ser muito crítico com o trabalho dos alunos.

Para trabalhar com o LabVirt elaborou seu plano de aulas mas teve que reorganizá-lo na questão do tempo. Por causa de outros projetos na escola o tempo previsto não foi suficiente. Para ele, planejar é fácil, executar o planejamento que é problema.

\section{E. Discussão dos dados}

Comparando os planos apresentados por P7 com suas concepções sobre planejamento percebemos dados contraditórios. Esse professor diz utilizar como referências para o planejamento os PCNs, ENEM e conhecimento dos alunos. Em seus planos, entretanto, não constam as habilidades e competências a serem alcançadas nem tão pouco a organização por temas estruturadores como propõem esses documentos.

Ao mesmo tempo em que P7 diz utilizar várias orientações para selecionar seus conteúdos diz que tem que cumprir uma norma da escola que é seguir o livro didático. Assim, entendemos que esse professor também é conteudista e que para cumprir com tanto conteúdo suas aulas são basicamente expositivas sem diversificar sua metodologia. 


\section{CONCLUSÕES}

O planejamento é uma prática que entendemos organizar e facilitar o trabalho do professor em sala de aula. Quando bem elaborado pode atuar como um instrumento de reflexão da prática educativa e de autonomia dos professores.

Neste trabalho nos propusemos investigar as concepções sobre planejamento e plano de ensino de sete professores atuantes na Rede Estadual de São Paulo e participantes do Projeto LabVirt da Escola do Futuro e investigamos se a participação no projeto possibilitou uma mudança nos planos de ensino desses professores. Para o desenvolvimento do projeto LabVirt, os professores tiveram de planejar suas ações minuciosamente e tiveram uma orientação para tal. Nossa hipótese, ao início do trabalho, era que os professores utilizariam essa orientação e perceberiam que refletir sobre suas aulas no momento da elaboração de um plano de ensino facilitaria seu trabalho em sala de aula. Assim, esperávamos modificações nos seus planos de curso pós-projeto.

Para o desenvolvimento desta investigação nos baseamos nas análises dos planos de ensino e questionários realizados pré e pós-projeto e entrevistas semiestruturadas. A partir desse material, unidades de informação foram selecionadas para a construção de categorias e mapas cognitivos.

Nossos dados mostram que, apesar dos professores julgarem que foi útil e importante a realização dos planos "aula a aula" durante o LabVirt, seus planos de ensino nas suas respectivas escolas pouco mudaram em relação aos mesmos planos préprojeto.

Os professores pesquisados entendem planejamento como plano de ensino, ou seja, o documento elaborado com os conteúdos conceituais que serão ensinados durante o ano letivo, e não como um processo que deva ocorrer durante o ano todo a fim de refletir sobre o processo de ensino-aprendizagem fazendo previsões para sua atuação.

Para a realização dos planos de ensino esses professores pensam basicamente nos conteúdos conceituais que irão trabalhar e em sua seqüência. Para seis dos sete professores investigados, os planos de ensino se resumem a uma listagem de conteúdos que apresentam tópicos e seqüências baseadas em livros didáticos tradicionais de Química. Esses planos estão estruturados de modo convencional para cinco dos sete professores, com objetivos gerais e/ou específicos, conteúdos, metodologia e avaliação, estrutura esta que é estabelecida na maioria das escolas. Dois destes professores, que trabalham na mesma escola, apresentaram somente conteúdos conceituais no plano préprojeto.

Para esses professores investigados, os planos de ensino servem como um roteiro orientador dos conteúdos conceituais que serão trabalhados e sua seqüência. 
Apesar de a unanimidade desses professores mencionarem, durante as entrevistas, que realizam avaliação diagnóstica, percebe-se pelas suas falas que essa avaliação não é feita de maneira planejada e em alguns casos não passa de um diálogo com os alunos no primeiro dia de aula para situá-los sobre quais capítulos do livro foram estudados e quais ainda faltam. Apesar disso, nem todos utilizam os resultados dessa avaliação para planejar ou replanejar, minimizando a função deste instrumento.

O objetivo do ensino de Química, segundo esses professores, é o de cumprir com uma transmissão de conteúdos que são determinados basicamente pelos vestibulares. Tendo esse objetivo em mente, existe uma coerência com a quantidade de conteúdos e seqüência que aparecem nos planos tanto pré como pós-projeto. As falas e algumas respostas às questões dos questionários revelam, entretanto, algumas ações distintas em sala de aula em relação ao que aponta o documento entregue na coordenação. Por essas falas um ensino mais contextualizado parece acontecer em alguns casos, muito embora ele tenha de competir com a corrida que a transmissão dos conteúdos pressupõe.

Apesar dos professores revelarem serem autônomos para determinarem o currículo de Química mais adequado à sua realidade, apenas um professor propôs o ensino de Química a partir de temas geradores onde os conteúdos são necessários para o desenvolvimento destes temas, conforme propõem os PCNs, referência citada por esse professor para a elaboração de seu plano. Os outros seis professores mantiveram a seqüência padrão proposta pelos livros didáticos. Praticamente a única diferença entre eles é a relação de conteúdos selecionados, ora por disponibilidade de tempo de aula, ora por dificuldades que o professor enfrenta em dominar determinados assuntos.

A garantia dos conteúdos parece estar vinculada com a idéia de ser um bom professor e que para isso seria necessário garantir o básico para os alunos para que eles tenham chance de sucesso nos vestibulares e em suas escolhas futuras.

Esses professores fazem muito poucas alterações em seus planos de um ano para outro, o que mostra que não levam em consideração as necessidades que cada nova turma apresenta. No discurso, entretanto, dizem fazer um diagnóstico das turmas e dizem ser contra a memorização pura e simples. Numa escola, dois dos professores revelaram que possuem turmas muito distintas nos períodos matutino e noturno no que concerne aos seus objetivos e necessidades. No noturno os estudantes trabalham e passam por dificuldades financeiras e alguns até se envolveram em situações ilícitas. Nas turmas da manhã a realidade é totalmente distinta com alunos com melhor poder aquisitivo, que só estudam e que têm pretensões reais de prosseguir os estudos numa universidade. Apesar desse quadro, esses professores decidiram por uma padronização de conteúdos nos dois períodos para atender aos alunos que desejam ser remanejados 
de horário durante o ano letivo. Isso garantiria um currículo idêntico aos dois públicos de perfis totalmente diferentes.

Os resultados sobre as concepções e práticas dos professores quando planejam seu ensino mostram um perfil de atuação caracterizado por: a) o planejamento constituise num processo sem objetivos ideológicos; b) o conteúdo específico da disciplina é o elemento chave do processo; c) o livro didático constitui a referência fundamental para a seleção e seqüenciação dos conteúdos; d) o conhecimento que o professor tem de seus alunos é pouco considerado em suas tomadas de decisões durante o planejamento.

Apesar das atividades propostas pelo LabVirt possibilitarem que o professor construísse sua ação, preparando, organizando e tomando decisões sobre suas aulas, os resultados nos mostraram que esta participação pouco contribuiu para o entendimento do processo de planejamento e conseqüentemente não influenciou de maneira significativa a prática de planejar desses professores. 


\section{CONSIDERAÇÕES FINAIS}

Diante do quadro descrito acima, percebemos que os professores são simplistas na forma de planejar suas aulas e que um programa de formação contínua, nos moldes do LabVirt não teve êxito em promover mudanças no que concerne à questão do planejamento de ensino e planos de aulas. Ainda que esse não fosse o objetivo principal do projeto, esperava-se que o envolvimento nas atividades propostas pudesse gerar algumas modificações em suas concepções e, conseqüentemente, refletir em seus planos de ensino.

Apesar dos professores perceberem que um plano mais detalhado e refletido facilita o trabalho em sala de aula, julgam ter de dispor de um tempo que não dispõem para transferir essa organização no seu dia a dia. Alguns sentiram muita dificuldade em colocar no papel todos os detalhes necessários de se pensar numa aula e em fazer registros do que acontecia em sala de aula. Isso mostra que os professores ainda não perceberam a importância do ato de planejar e o significado deste ato para sua profissão e para a educação. Assim, nos parece que são meros reprodutores de currículos fechados, pré-estabelecidos pelos livros didáticos.

Por outro lado, hoje temos uma visão mais crítica quanto a programas de formação contínua e entendemos que parte da desconexão entre o discurso e a prática dos professores vem do fato de que tais programas acabam por impor também um "conteúdo' a esses professores que deve ser assimilado da mesma forma que eles realizam com seus alunos. A dificuldade encontrada por esses professores não foi em aplicar o projeto das simulações em sala de aula e aparentemente até realizaram um bom trabalho nessa direção. O grande problema, entretanto, é modificar as ações rotineiras desses professores e, para que isso seja possível, entendemos que um programa de formação contínua deve partir da realidade concreta dos professores, auxiliando-os a enfrentar as dificuldades reais encontradas por eles nas suas respectivas escolas. No nosso entender, os programas de formação contínua necessitam trabalhar a autonomia dos professores para que eles lidem com a sua realidade de escola e alunos e tentem obter melhorias a partir do que o professor já consegue realizar. Acreditamos que, assim, seria obtido um sucesso mais abrangente.

Uma possível explicação para o descompasso entre o discurso e a prática em relação ao planejamento desses professores encontra-se na sua formação acadêmica. Todos eles mencionam que quase não discutiram sobre planejamento na formação inicial e o pouco que fizeram não foi suficiente para entender como isso se processa. O contato mais efetivo com esse processo aconteceu nas escolas já como professores e eles 
simplesmente reproduzem uma história de ensino tradicional e conteudista. Portanto, enfatizamos a necessidade de dar uma maior importância ao planejamento como instrumento didático de reflexão sobre a prática e como orientador da mesma, tanto na formação inicial como contínua de professores.

Por outro lado, acreditamos que os planos que foram apresentados pelos professores não refletem de maneira fiel suas práticas e, portanto, entendemos que para confirmarmos se o plano realmente é utilizado e seguido pelo professor deveríamos acompanhar suas aulas ao longo do ano.

Este trabalho, além de traçar um perfil desses professores com relação às concepções sobre o planejamento, traz um alerta aos cursos de formação contínua e enfatiza a necessidade desses atuarem a partir da realidade de sala de aula dos professores para alcançarem o êxito pretendido, produzindo reflexos em suas práticas educativas diárias. 


\section{REFERÊNCIAS BIBLIOGRÁFICAS}

ALMEIDA, Maria Isabel. O sindicato como instância formadora dos professores: novas contribuições ao desenvolvimento profissional. Tese de Doutorado. Faculdade de Educação,1999. 225p.

APEOESP. Ler e escrever na escola. Planejamento/2005. Cadernos de Formação, n.15, 2005.

Planejamento. Cadernos de Formação, n.10, 2001.

BEATTIE, Mary. New Prospects for Teacher Education: Narrative Ways of Knowing Teaching and Teacher Learning. Educational Research, 37(1), p.53-70, 1995.

BOGDAN, Robert C.; BIKLEN, Sari K. Investigação qualitativa em educação. Uma introdução à teoria e aos métodos. Porto: Porto Ed., 1994.

BRASIL. Lei de Diretrizes e Bases da Educação Nacional, Lei nº 9.394, de 20 de dezembro de 1996.

. Ministério da Educação, Secretaria da Educação Média e Tecnológica (Semtec). Parâmetros Curriculares Nacionais: Ensino Médio. Brasília: MEC/Semtec, 1999.

- Ministério da Educação (MEC), Secretaria da Educação Média e Tecnológica (Semtec). PCN+Ensino Médio: Orientações Educacionais Complementares aos Parâmetros Curriculares Nacionais - Ciências da Natureza, Matemática e suas Tecnologias. Brasília: MEC/Semtec, 2002.

Ministério da Educação (MEC), Secretaria de Educação Básica (SEB), Departamento de Políticas de Ensino Médio. Orientações Curriculares do Ensino Médio. Brasília: MEC/SEB, 2004.

BULWIK, Marta. Formación docente continua: más que una necesidad. Educación Química, 11(3), p. 294-299, 2000. 
CAMPOS, Roselane F.; SHIROMA, Eneida O. O resgate da Escola Nova pelas reformas educacionais contemporâneas. Revista Brasileira de Estudos Pedagógicos, 80 (196), p. 483-493, 1999.

CARVALHO, Anna Maria P. (Org.). Ensino de Ciências: unindo a pesquisa e a prática. São Paulo: Pioneira Thomson Learning, 2004. 151p.

CENP - Coordenadoria de Estudos de Normas e Pedagógicas. Programa Nacional do Livro para o Ensino Médio (PNLEM), 2007. Disponível em: <http://cenp.edunet.sp.gov.br/PNLEM/default.asp> Acesso em: 02/11/2007.

CENP - Coordenadoria de Estudos e Normas Pedagógicas. Programa de Formação Continuada "Teia do Saber", (2005). Disponível em: <http://cenp. edunet.sp.gov.br/TRSaber/Teia_saber/Projeto\%20B\%E1sico\%20-\%202005.pdf>. Acesso em 24/10/2007.

COLL, César; PALACIOS, Jesús; MARCHESI, Álvaro (Orgs.). Desenvolvimento Psicológico e Educação. v. 2. Porto Alegre: Artes Médicas Sul, 1996.

COPELLO LEVY, Maria Inês; SANMARTí PUIG, Neus. Fundamentos de um modelo de formación permanente del profesorado de ciencias centrado em la reflexión dialógica sobre las concepciones y las prácticas. Enseñanza de las Ciencias, 19(2), p. 269-283, 2001.

CUNHA, Ana M. O.; KRASILCHIK, Myriam. A Formação Continuada de Professores de Ciências: percepções a partir de uma experiência. [online\} In: XXIII Reunião Anual da ANPED. Caxambú, 2000. Disponível em: <http://www.anped.org.br/23/textos/0812t.PDF> Acesso em: 18/08/2006.

DÁLMAS, Angelo. Planejamento participativo na escola: elaboração, acompanhamento e avaliação. 12 ed. Petrópolis, RJ: Vozes, 1994.

DEMO, Pedro. Pesquisa e Construção de Conhecimento: metodologia científica no caminho de Habermas. Rio de Janeiro: Tempo Brasileiro, 1997. 125p.

FEJES, Marcela; NAVAS, Ana Maria; NEVES, Denise; MAXIMIANO, Flavio; AKAHOSHI, Luciane; LOPES DE MENEZES, Silvia; NUNES, César A. A. LabVirt 
Química: una experiencia brasilera de redes colaborativas entre la universidad y la escuela. Enseñanza de Las Ciencias, 2005a. Número extra. VII Congreso. Disponível em: <http://www.labvirtq.futuro.usp.br> Acesso em: 26/08/2006.

- Laboratorio Didáctico Virtual - Química: redes colaborativas entre universidad y escuela para producir simulaciones interactivas. In: Virtua Educa, México, 2005b. Disponível em: http://www.labvirtq.futuro.usp.br. Acesso em: 26/08/2006.

- Laboratorio Didáctico Virtual - Química: redes colaborativas entre universidad y escuela para producir simulaciones interactivas. In: II Congreso Iberoamericano de Educared "Educación y Nuevas Tecnologias", 2005c. Disponível em: <http://www.labvirtq.futuro.usp.br> Acesso em: 26/08/2006.

FERREIRA, Aurélio B. H. Dicionário Aurélio Básico da Língua Portuguesa. Rio de Janeiro: Nova Fronteira, 1988.

FURIÓ, Carles; CARNICER, Jesús. El desarrollo profesional del profesor de ciencias mediante tutorías de grupos cooperativos. Estudio de ocho casos. Enseñanza de las Ciencias, 20(1), p.47-73, 2002.

FUSARI, José C. O papel do planejamento na formação do educador. São Paulo, SE/CENP, 1988.

- O planejamento do trabalho pedagógico: algumas indagações e tentativas de respostas. Série Idéias. São Paulo: FDE, v.8, p. 44-53, 1990.

GANDIN, Danilo. Posição do planejamento participativo entre as ferramentas de intervenção na realidade. Currículo sem Fronteira. v.1, n.1, p. 81-95, 2001.

GARCIA, Carlos M. Formación del Profesorado para el Cambio Educativo. Barcelona: EBU, 1994.

GARRIDO, Elsa; CARVALHO, Anna M. P. A importância da reflexão sobre a prática na qualificação da formação inicial do professor. Cadernos de Pesquisa. São Paulo. n.107, p.149-168, 1999. 
GIL-PÉREZ, Daniel; CARVALHO, Anna M. P. Formação de Professores de ciências: tendências e inovações. 3 ed. São Paulo: Cortez, 1998. 120p.

. Dificuldades para la incorporación a la enseñanza de los hallazgos de la investigación e innovación en didáctica de las ciencias. Educación Química, 11(2), p.244$251,2000$.

GOODSON, Ivor. A construção social do currículo. Lisboa: Educa, 1997.

GONZÁLEZ GARCÍA, Fermín María. Los mapas conceptuales de J. D. Novak como instrumentos para la investigación en didáctica de las ciencias experimentales. Enseñanza de las Ciencias, 10(2), p.148-158, 1992.

GONZÁLEZ, Teodoro; BERMEJO, Maria L.; MELLADO, Vicente. Los mapas cognitivos elaborados a partir de entrevistas. Un procedimiento de análisis para comparar las concepciones del profesorado sobre la enseñanza de las ciencias. In: Proceedings of the First International Conference on Concept Mapping. Pamplona, Espanha, 2004. Disponível em: http://cmc.ihmc.us/papers/cmc2004-017.pdf. Acesso em: 06/07/2005.

KENSKI, Vani M. Repensando a avaliação da aprendizagem. In: Veiga, Ilma P. A. (coord.). Repensando a didática. 21 ed. São Paulo: Papirus, 2004.

KITCHIN, Robert M. Cognitive maps: what are they and why study them? Journal of Environmental Psycology, 14, p.1-19, 1994.

KRASILCHIK, Myriam. O professor e o currículo das ciências. São Paulo: EPU, 1987. 80p.

LABVIRT - $\quad$ Laboratório Didático Virtual (2005). http://www.futuro.usp.br/projetos/proj_labvirt.htm

LLINARES, Salvador. Los mapas cognitivos como instrumento para investigar las creencias epistemológicas de los profesores. In: Marcelo, Garcia. La investigación sobre la formación del profesorado. Métodos de investigación y análisis de dados. Buenos Aires: Cincel, 1992. 
LIMA, Maria E. C. C. Formação continuada de professores de Química. Química Nova na Escola, n.4, p.12-17, 1996.

LOPES, Antonia O. Planejamento do ensino numa perspectiva crítica de educação. In: Veiga, IIma P. A. (coord.). Repensando a didática. 21 ed. São Paulo: Papirus, 2004.

MALDANER, Otávio. A. A formação inicial e continuada de professores de Química: professores/pesquisadores. ljuí: Unijuí, 2000. 424p.

MARTINS, Pura L. O. Conteúdos escolares: a quem compete a seleção e a organização? In: Veiga, Ilma P. A. (coord.). Repensando a didática. 21 ed. São Paulo: Papirus, 2004.

MELLADO, Vicente. Concepciones y prácticas de aula de profesores de ciencias em formación inicial de primaria y secundaria. Enseñanza de las Ciencias, 14(3), p. 289302, 1996.

Preservice teachers' classroom practice and their conceptions of the nature of science. Science and Education, 6(4), p.331-354, 1997.

. The classroom practice of preservice teachers and their conceptions of teaching and learning science. Science Education, 82(2), p.197-214, 1998.

MENEGOLLA, Maximiliano; SANT'ANNA, Ilza M. Por que planejar? Como planejar? Currículo-Área-Aula. 13. ed. Petrópolis: Vozes, 2003. 159p.

MILES, Matthew B.; HUBERMAN, A. Michael. Drawing valid meaning from qualitative data: toward a shared craft. Educational Researcher, 13(5), p.20-30, 1984.

NOVAK, Joseph; GOWIN, Bob.; Aprendiendo a aprender. Barcelona: Martínez Roca, 1988. 228p.

NÓVOA, Antonio. Os professores e a sua formação. Lisboa: Dom Quixote, 1995. 
ONTORIA, Antonio; BALLESTEROS, Ana; CUEVAS, Carmen; GIRALDO. Lourdes; MARTíN, Inmaculada; MOLINA, Ana, RODRíGUEZ, Álvaro; VÉLEZ, Ursula. Mapas conceptuales. Una tecnica para aprender. 5 ed. Madrid: Narcea, 2001. 203p.

PACCA, Jesuína L. A. O profissional de educação e o significado do planejamento escolar: problemas dos programas de atualização. Revista Brasileira de Ensino de Física, 14(1), 1992.

PARKE, Helen M.; COBLE, Charles R. Teachers designing curriculum as professional development: a model for transformational science teaching. Journal of Research in Science Teaching, 34(8), p.773-789, 1997.

RODRIGUES, Ângela; ESTEVES, Manuela. A análise de necessidades na formação de professores. Porto: Porto Editora, 1993.

RUIZ, Constantino; SILVA, Consuelo; PORLÁN, Rafael; MELLADO, Vicente. Construcción de mapas cognitivos a partir del cuestionario INPECIP. Aplicación al estudio de la evolución de las concepciones de una profesora de secundaria entre 1993 y 2002. Revista Electrónica de Enseñanza de las Ciencias, 4(1), 2005. Disponível em:http://www.saum.uvigo.es/reec/volumenes/volumen4/ART3_Vol4_N1.pdf\#search=\%2 $2 \% 20 \% 22$ construcci\%C3\%B3n\%20de\%20mapas\%20cognitivos\%22\%22. Acesso em: 06 de julho de 2005.

SÁNCHEZ BLANCO, Gaspar; VALCÁRVEL PÉREZ, Maria V. Diseño de unidades didácticas em el área de ciencias experimentales. Enseñanza de las Ciencias, 11(1), p.33-44, 1993.

Science teacher's views and practices in planning for teaching. Journal of Research in Science Teaching, 36(4), p.493-513, 1999.

Qué tienen em cuenta los profesores cuando seleccionan el contenido de enseñanza? Cambios y dificultades tras un programa de formación. Enseñanza de las Ciencias, 18(3), p.423-437, 2000.

SANTOS, Wildson L. R.; SCHNETZLER, Roseli P. Função Social: O que significa ensino de Química para formar o cidadão? Química Nova na Escola, n.4, p.28-34, 1996. 
SÃO PAULO. Secretaria de Estado da Educação. Subsídios para o planejamento escolar/2006. São Paulo: 2006, 8p. Disponível em: http://cenp.edunet.sp.gov.br/Progestao2/arq/A\%20ESCOLA\%20E\%200S\%20SEUS\%20I NDICADORES.doc>. Acesso em: 06/06/2006.

. Secretaria de Estado de Educação. Planejamento 2005. Orientações para elaboração do planejamento nas escolas e na Diretoria de Ensino. São Paulo: 2005, $25 \mathrm{p}$.

Disponível

em:

http://cenp.edunet.sp.gov.br/Plan2005/planejamento2005.pdf\#search=\%22\%20\%22orient a\%C3\%A7\%C3\%B5es\%20para\%20elabora\%C3\%A7\%C3\%A3o\%20do\%20planejamento \%20nas\%20escolas\%20e\%20na\%22\%22. Acesso em: 10/05/2005.

SCHNETZLER, Roseli P. Concepções e alertas sobre formação continuada de professores de Química. Química Nova na Escola, n.16, p.15-20, 2002.

SOUZA, Denise T. R. A formação contínua de professores como estratégia fundamental para a melhoria da qualidade do ensino: uma reflexão crítica. In: OLIVEIRA, Marta Kohl; SOUZA, Denise T. R.; REGO, Teresa C., (Orgs.). Psicologia, educação e as temáticas da vida contemporânea. São Paulo: Moderna, 2002.

TURRA, Clódia; SANT'ANNA, Flávia; ENRICONE, Délcia; ANDRÉ, Lenir. Planejamento de Ensino e Avaliação. 11. ed. Porto Alegre: Sagra Luzzatto, 2004. 304p.

VASCONCELLOS, Celso S. Planejamento: Plano de Ensino-Aprendizagem e Projeto Educativo. 10. ed. São Paulo: Libertad, 2002. 205p.

VILLANI, Alberto. Planejamento escolar: um instrumento de atualização dos professores de ciências. Revista de Ensino de Física, 13, p.162-177, 1991.

VILLANI, Alberto; FREITAS, Denise. Formação de professores de ciências: um desafio sem limites. Investigações em Ensino de Ciências [on-line], 7(3), 2002. Disponível em: http://www.if.ufrgs.br/public/ensino/revista.htm. Acesso em 08/08/2006.

VILLANI, Alberto; PACCA, Jesuína L. A. Estratégias de ensino e mudança conceitual na atualização de professores. Revista Brasileira de Ensino de Física, 14(4), p.222-228, 1992. 
Construtivismo, conhecimento científico e habilidade didática no ensino de ciências. Revista da Faculdade de Educação, São Paulo, 23(1-2), 1997. Disponível em: http://www.scielo.br/. Acesso em: 08/08/2006.

ZABALLA, Antoni. A prática educativa: como ensinar. Porto Alegre: Artmed, 1998. $224 p$. 


\section{ANEXOS \\ ANEXO 1. PLANEJAMENTO GERAL DE UNIDADES DIDÁTICAS - LABVIRT}

\section{Plano de aulas - LabVirt}

Proposta geral de planejamento de aulas que incorpora desenvolvimento de simulações e trabalho por projetos. Cada aula tem uma duração de 50 minutos.

\section{Aula 1 - Exploração de conceitos}

Objetivo:

Identificar os conhecimentos dos alunos sobre o tema ou conteúdo selecionado.

Atividades para desenvolver em aula:

- Listar palavras que apresentem os conceitos centrais do tema selecionado.

- Formar pequenos grupos de alunos (3-4) e pedir uma definição para cada um deles.

- Comparar, de maneira conjunta, as definições, e construir em grupo uma única definição.

\section{Aula 2 - Introdução de novos conceitos}

Objetivo:

Introduzir e apresentar novos conceitos relacionados com o tema de estudo, a partir da identificação do conhecimento prévio dos alunos.

Atividades para desenvolver em aula:

- Discutir dúvidas e perguntas sobre o tema apresentado.

- Desenvolver, em grupo, problemas do livro de texto.

\section{Aula 3 - Introdução de novos conceitos}

Objetivo:

Introduzir e apresentar novos conceitos relacionados com o tema de estudo, a partir da identificação do conhecimento prévio dos alunos. 
Atividades para desenvolver em aula:

- Desenvolver, se necessário, uma prática de laboratório.

- Discutir dúvidas e perguntas sobre o tema tratado na prática ou em sala.

- Pedir como tarefas de casa a identificação de situações problema do cotidiano, que estejam relacionadas com o tema tratado.

Atividades para desenvolver fora de aula:

- Solicitar o uso da sala de informática para desenvolver as atividades propostas na aula 4.

\section{Aula 4 - Apresentação do LabVirt}

Objetivo:

Apresentar o projeto LabVirt Química, os serviços educativos que oferece e as metodologias de trabalho e avaliação propostas.

Atividades para desenvolver em aula:

- Apresentar o projeto de forma geral.

- Apresentar 2 simulações do LabVirt na sala de informática.

- Pedir aos alunos que pensem como o problema identificado poderia ser tratado através de uma simulação.

- Pedir como lição de casa um esboço com a primeira idéia de simulação por grupos de 3 ou 4 alunos.

\section{Aula 5 - Discussão de idéias para as simulações}

Objetivos:

Analisar, através de apresentações orais e discussões de grupo, as diferentes idéias propostas para as simulações.

Atividades para desenvolver em aula:

- Apresentação oral das diferentes idéias.

- Discussão

Aula 6 - Elaboração do roteiro de encomenda de simulação 
Objetivo:

Iniciar o processo de elaboração do roteiro para a encomenda das simulações.

Atividades a desenvolver em aula:

- Fornecimento de fontes de consulta aos alunos (livros, fotocópias, serviços educativos do website do LabVirt, etc.).

- Trabalho em grupos de 3 ou 4 alunos para desenvolver os conteúdos da simulação.

- Atendimento de dúvidas e perguntas dos alunos.

\section{Aula 7 - Elaboração do roteiro de encomenda de simulação}

Objetivo:

Continuar com o processo de elaboração do roteiro para a encomenda das simulações.

Atividades a desenvolver em aula:

- Fornecimento de fontes de consulta aos alunos (livros, fotocópias, serviços educativos do website do LabVirt, etc.).

- Trabalho em grupos de 3 ou 4 alunos para desenvolver os conteúdos da simulação.

- Atendimento de dúvidas e perguntas dos alunos.

Atividades para desenvolver fora de aula:

- Solicitar o uso da sala de informática para desenvolver as atividades propostas na aula 8.

\section{Aula 8 - Elaboração do roteiro de encomenda de simulação}

Objetivo:

Continuar com o processo de elaboração do roteiro para a encomenda das simulações.

Atividades a desenvolver em aula:

- Fornecimento de fontes de consulta aos alunos (livros, fotocópias, serviços educativos do website do LabVirt, etc.).

- Trabalho em grupos de 3 ou 4 alunos para desenvolver os conteúdos da simulação. 
- Atendimento de dúvidas e perguntas dos alunos.

Atividades para desenvolver fora de aula:

- Solicitar o uso da sala de informática para desenvolver as atividades propostas na aula 9.

Aula 9 - Elaboração do roteiro de encomenda de simulação

Objetivo:

Continuar com o processo de elaboração do roteiro para a encomenda das simulações.

Atividades para desenvolver em aula:

- Trabalho em grupos de 3 ou 4 alunos para continuar o processo de digitalizar a informação.

- Atendimento de dúvidas e perguntas dos alunos.

- Envio de roteiros via e-mail. 
ANEXO 2. ROTEIRO ORIENTADOR PARA ELABORAÇÃO DO PLANO DE ENSINO E DE AULA

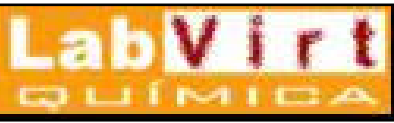

UNIVERSIDADE DE SÃO PAULO

\section{QUÍMICA}

\section{PLANEJAMENTO 2005}




\section{PLANEJAR OU NÃO PLANEJAR O ENSINO?}

Certos professores rejeitam ou desacreditam na ação de planejar. Quais seriam as causas?

Segundo Menegolla e Sant'Anna:

- Superficial conhecimento e o pouco preparo que os professores possuem sobre o planejamento e a sua validade científica, pedagógica e didática.

- Carência de objetivos claros e bem definidos sobre a importância de tal ato.

- São exigidos planejamentos sofisticados, mas de pouca funcionalidade na sala de aula.

Porém planejar é uma exigência do ser humano: é um ato de pensar sobre um possível e viável fazer. E como o homem pensa o seu "quê fazer", o planejamento se justifica por si mesmo. A sua necessidade é a sua própria evidência e justificativa (MENEGOLLA e SANT'ANNA, 2003).

Entende-se por planejamento um processo de previsão de necessidades e racionalização do emprego dos meios materiais e dos recursos humanos disponíveis, a fim de alcançar objetivos concretos, em prazos determinados e em etapas definidas, a partir do conhecimento e avaliação científica da situação original.

A partir dessa definição podemos concluir que todo planejamento requer:

- Conhecimento da realidade, das suas urgências, necessidades e tendências;

- Definição de objetivos claros e significativos;

- Determinação de meios e de recursos possíveis, viáveis e disponíveis;

- Estabelecimento de critérios e de princípios da avaliação para o processo de planejamento e execução;

- Estabelecimento de prazos e etapas para a sua execução.

É preciso planejar uma educação que pelo processo dinâmico possa ser criadora e libertadora do homem. Planejar uma educação que não limite, mas que liberte, que conscientize e comprometa o homem diante do seu mundo. O planejamento, quando levado a sério e respeitado o seu rigor técnico, se constitui numa ferramenta teórico- 
metodológica capaz de dar sentido àquilo que se faz, de definir aquilo que se quer e de, concretamente, transformar realidades.

\section{FINALIDADES DO PLANEJAMENTO}

*Extraído do Livro Planejamento: Projeto de Ensino-Aprendizagem e Projeto Político-Pedagógico (VASCONCELLOS, C.S., 2002).

\section{Planejamento em geral}

- Despertar e fortalecer a esperança na história como possibilidade;

- Ser um instrumento de transformação da realidade;

- Resgatar a intencionalidade da ação (marca essencialmente humana), possibilitando a (re)significação do trabalho, o resgate do sentido da ação educativa;

- Combater a alienação: explicitar e criticar as pressões sociais e os compromissos ideológicos; tomar consciência de que projeto está se servindo;

- Dar coerência à ação da instituição, integrando e mobilizando o coletivo em torno de consensos (provisórios); superar o caráter fragmentário das práticas educativas, a mera justaposição;

- Ajudar a prever e superar dificuldades; fortalecer o grupo para enfrentar conflitos e contradições;

- Racionalizar os esforços, o tempo e os recursos (eficiência e eficácia): utilizados para atingir fins essenciais do processo educacional;

- Diminuir o sofrimento.

\section{Projeto de ensino-aprendizagem}

- Possibilitar a reflexão e a (re)significação do trabalho;

- Resgatar o espaço de criatividade do educador;

- Favorecer a pesquisa sobre a própria prática;

- Organizar adequadamente o currículo, racionalizando as experiências de aprendizagem, tendo em vista tornar a ação pedagógica mais eficaz e eficiente;

- Estabelecer a comunicação com outros professores e alunos;

- Ajudar a resgatar o movimento conceitual e a organizar o fluxo da expressão sobre o objeto de conhecimento; 
- Não desperdiçar atividades e oportunidades de aprendizagem;

- Ser elemento de auto-formação do professor, na medida em que possibilita o pensar mais sistematicamente sobre a realidade, sobre a proposta, sobre a prática, ajudando, pois, a diminuir a distância teoria-prática, evitando a rotina viciada e a improvisação;

- Resgatar o saber docente, a cultura pedagógica do grupo;

- Superar a expropriação a que o professor foi submetido em relação à concepção e ao domínio do seu quê fazer, resgatando sua condição de sujeito transformador.

\section{ROTEIRO DE ELABORAÇÃO DO PROJETO DE ENSINO-APRENDIZAGEM}

\section{Grande desafio:}

Mudar a mentalidade de que fazer planejamento é preencher formulários (mais ou menos sofisticados). Antes de tudo, fazer planejamento é refletir sobre os desafios da realidade da escola e da sala de aula, perceber as necessidades, re-significar o trabalho, buscar formas de enfrentamento e comprometer-se com a transformação da prática.

O Projeto de Ensino-Aprendizagem pode ser subdividido basicamente, quanto ao nível de abrangência, em Plano de Ensino e Plano de Aula. Faremos a seguir algumas considerações sobre o aspecto mais operacional, o 'como' fazer, como organizar isto no cotidiano na escola. Gostaríamos, no entanto, de deixar claro que não se trata de um modelo, mas de possibilidades, que têm o objetivo de provocar a reflexão dos educadores na busca de suas próprias alternativas, tendo em vista sua realidade e a caminhada de cada grupo.

\section{PLANO DE ENSINO}

O Plano do ensino é a sistematização da proposta geral de trabalho do professor naquela determinada disciplina ou área de estudo, numa dada realidade. Pode ser anual ou semestral, dependendo da modalidade em que a disciplina é oferecida. 
Possíveis Elementos do Plano de Ensino

\begin{tabular}{|c|c|}
\hline Dimensão & Elementos \\
\hline Análise da Realidade & $\begin{array}{l}\text { - Identificação } \\
\text { - Caracterização da Realidade } \\
\text { - Sujeitos } \\
\text { - Objeto } \\
\text { - Contexto } \\
\text { - Necessidades }\end{array}$ \\
\hline Projeção dę Finalidades & $\begin{array}{ll}\text { - } & \text { Finalidade da Escola } \\
\text { - } & \text { Fundamentos da Disciplina }\end{array}$ \\
\hline Formas de Mediação & $\begin{array}{l}\text { - } \text { Quadro Geral de Conteúdos } \\
\text { - Proposta Geral Metodológica } \\
\text { - } \text { Proposta de Avaliação } \\
\text { - } \text { Fontes de Pesquisa } \\
\text { - Interação com outras Disciplinas } \\
\text { - Integração com Atividades Extraclasse } \\
\text { - Normas Estabelecidas } \\
\text { - Observações }\end{array}$ \\
\hline
\end{tabular}

Identificação.

Registro do nome da Escola, da Disciplina a ser ministrada, do(s) Professor(es), da série, do número de turmas, do(s) turno(s) (manhã, tarde, noite), da duração (anual, semestral), carga horária prevista. A identificação remete a toda vinculação institucional.

\section{Caracterização da Realidade}

- Sujeitos (professor, alunos)

Registro de elementos relevantes e características gerais percebidas. Em relação ao professor, no início pode haver dificuldade para o registro; não tem problema: o importante é insistir no processo de reflexão crítica. 
Registro do número de aulas semanais, número de dias letivos, aulas previstas por bimestre e no total. Indicação de articulação da disciplina com série anterior e posterior (quando houver).

- Contexto (Escola, Comunidade)

Registro de elementos relevantes e características gerais percebidas. Parte dos registros aqui indicados podem ser feitos antes do início das aulas, em função da experiência do educador; outra parte, apenas depois do conhecimento das turmas.

\section{Necessidades}

Tendo em vista os levantamentos feitos, e contando com a sua experiência anterior, cabe a reflexão do professor a fim de procurar identificar e explicitar as necessidades educacionais (porquê), cujo trabalho posterior visará superá-las. É preciso esclarecer que existem necessidades que são bastante específicas de determinado contexto, mas outras são mais gerais, podendo o professor se basear em sua prática acumulada; estas necessidades presumidas, no entanto, devem ser verificadas empiricamente.

\section{Finalidade de Escola}

Explicitação das finalidades gerais da escola (para quê - amplo). Buscar estas finalidades no Projeto Político-Pedagógico.

\section{Fundamentos da Disciplina}

Trata-se de explicitar os fundamentos da disciplina a ser oferecida, e que revelam o sentido e força do ensino daqueles conteúdos.

\section{Sobre os fundamentos}

O pano de fundo aqui é a pergunta que os alunos sempre têm em mente, mas nem sempre expressam: 'Para que estudar esta matéria?' É a justificativa do ensino da disciplina: como o professor defende a existência da matéria no currículo? Qual é seu papel no desenvolvimento dos alunos, na formação da cidadania? Qual sua origem? Como chegou ao que é hoje? (resgate da história da disciplina). Que relação mantém com a vivência do aluno, com a sociedade, com outras disciplinas? Que mudanças tem havido no ensino da disciplina nos últimos anos? Quais são as tendências atuais do ensino? 
Implica, pois, a explicitação dos objetivos gerais da disciplina/área para aquela série/nível (para quê). Ocorre que, quando se solicita simplesmente que o professor expresse os objetivos, há uma tendência de reproduzir os já colocados nos anos anteriores ou mesmo de copiar aqueles que vêm no livro didático. Ao serem solicitados os fundamentos, como é algo que não está pronto, vai ter que elaborar. Isto vai exigir muita pesquisa e reflexão do professor, e também o trabalho coletivo, dada a necessidade de partilhar com seus pares suas carências, buscas e descobertas.

Esta é uma tarefa da maior importância, pois está em questão, antes de tudo, a re-significação do trabalho pedagógico para o próprio professor, ganhando clareza da relevância e alcance do ensino da sua disciplina, coisa que, como já indicamos, muitas vezes lhe foi negada na sua formação.

\section{Quadro Geral de Conteúdos}

Proposta geral de conteúdos do curso (o quê), o programa que se pretende desenvolver. Entendemos os Conteúdos como sendo o conjunto de conhecimentos, hábitos e atitudes, organizados pedagógica e didaticamente; são os meios para a concretização das finalidades que o educador tem ao preparar o seu curso, a partir da realidade. Estão implicadas aqui as tarefas de seleção, organização e seqüenciação dos conteúdos.

Os conteúdos geralmente são agrupados em unidades temáticas e vêm com uma primeira previsão de divisão por bimestres.

\section{Sobre os Tipos de Conteúdos}

Quando da elaboração do plano, o professor deve ter a lucidez de que os conteúdos a serem trabalhados em sala de aula, não devem ficar limitados aos conceitos, informações, etc. Para que tenhamos uma formação integral da pessoa, necessário se faz articular este trabalho com o conhecimento - que é ponto base e até definidor da especificidade da contribuição da escola neste processo educativo - com outras dimensões, a saber, o desenvolvimento de habilidades e a criação de atitudes favoráveis. Esquematicamente, podemos assim apresentar os três tipos de conteúdos:

\begin{tabular}{|c|c|c|l|}
\hline Tipo & Dimensão & Significado & \multicolumn{1}{c|}{ Abrangência } \\
\hline Conceitual & "Saber" & Representações & Conhecimentos de fatos, \\
& & ou conteúdos & fenômenos, conceitos, princípios, \\
& & de consciência & leis, saberes, idéias, imagens, \\
& & & esquemas, informações \\
\hline
\end{tabular}




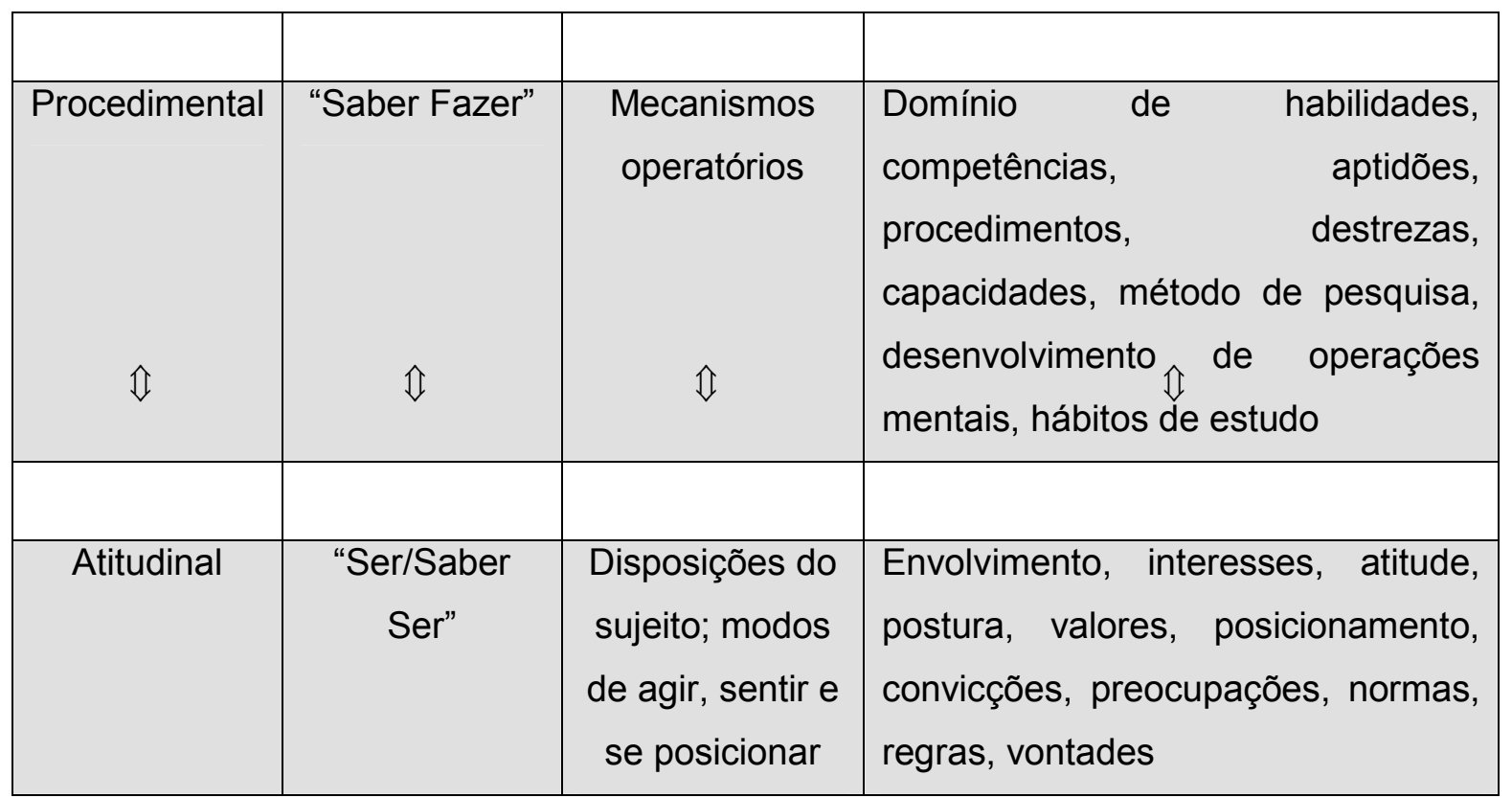

\section{Proposta Geral Metodológica}

Explicitação do caminho geral (como) que o professor pretende seguir no desenvolvimento da disciplina/área.

Aqui o professor pode fazer uma apresentação dos princípios metodológicos que sustentam sua prática, ou ainda indicar a metodologia que normalmente utiliza em sala de aula; não significa que seja a única, mas corresponde um pouco ao 'jeitão' do professor dar suas aulas.

Pode também incluir uma Orientação de Estudo para os alunos em relação à sua disciplina, tendo em vista o melhor aproveitamento.

\section{Proposta de Avaliação}

Apresentação do processo de avaliação a ser utilizado no decorrer do curso (como identificar necessidades). Pode-se explicitar o quê, como, para quê avaliar. Definir bem as regras do jogo da avaliação com os alunos, para evitar criar ansiedade e desconfiança na relação pedagógica. No caso de trabalhar com notas e conceitos, é importante deixar claro como vai se chegar a eles.

\section{Fontes de Pesquisa}

Relação de livros, textos, vídeos, CD’s, sites da Internet, revistas, secções de jornais ou programas de televisão correlatos aos assuntos a serem trabalhados, que serão utilizados ou que podem ser consultados. No caso de livros, pode-se detalhar o que é didático, o que é paradidático, o que é leitura sugerida e ainda o que é fundamento para o trabalho do professor. 


\section{Integração com outras Disciplinas}

Explicitação do trabalho interdisciplinar previsto. Aqui também podem ser colocadas as propostas de trabalho com os temas transversais. Pode-se registrar desde simples 'ganchos' para possíveis integrações, até pequenos projetos já definidos.

\section{Integração com Atividades Extra-classe}

Indicação da forma de integração da disciplina/área com atividades extra-classe previstas pela escola (ex: Mostra Cultural, Feira de Ciências, Olimpíada, Comemorações, etc).

\section{Normas Estabelecidas}

Registro do contrato pedagógico, das normas de convivência em sala de aula que foram estabelecidas em classe. Lembrar que as normas devem ser elaboradas visando às necessidades do trabalho pedagógico em todas as dimensões. É recomendável que não se tenha 'pressa' na sua construção, nem que sejam feitas 'só para entregar para a coordenação'.

\section{Observações}

Espaço para registros do professor sobre o desenvolvimento do processo na sua globalidade. O trabalho de ensino-aprendizagem é muito complexo e dinâmico; recorrer ao registro escrito é uma forma de fazer memória e possibilitar o aperfeiçoamento do projeto.

\section{PLANO DE AULA}

É a proposta de trabalho do professor para uma determinada aula ou conjunto de aulas (por isto chamado também de Plano de Unidade). Corresponde ao nível de maior detalhamento e objetividade do processo de planejamento didático. É a orientação para o quê fazer cotidiano. Muitos professores consideram que 'este é o planejamento que importa mesmo', o que não deixa de revelar uma dose de bom senso. Apenas lembramos que o plano poderá ter muito mais consistência e organicidade se estiver articulado ao Projeto de Curso e ao Projeto Político-Pedagógico da Escola. Por outro lado, a elaboração do Projeto de Curso não elimina o preparo de cada aula, pelo contrário, o pressupõe como complemento de realização.

Em princípio, a aula pode ser encaminhada de inúmeras maneiras. Planejar significa antever uma forma possível e desejável. Se não há planejamento, corre-se o risco de se desperdiçarem oportunidades muito interessantes. Não dá para dar aula 
improvisando, em off e se não ficar boa, 'regravar' (como os programas de televisão). Não planejar pode implicar perder possibilidades de melhores caminhos, perder pontos de entrada significativos.

Devemos destacar a necessidade de uma visão geral em relação ao que vai ser trabalhado na aula: se uma parte não está bem planejada, corre-se o risco de se ocupar muito tempo com outra, até como estratégia inconsciente do professor, mas prejudicando naturalmente os alunos.

Da mesma forma que os outros projetos, o Plano de Aula deve ser feito, antes de mais nada, como uma necessidade do professor e não por exigência formal da coordenação ou direção.

\begin{tabular}{|c|c|}
\hline Dimensão & Elementos \\
\hline$\underset{\Uparrow}{\text { Análise da Realidade }}$ & $\begin{array}{ll}\text { - } & \text { Assunto } \\
\text { - } & \text { Necessidades }\end{array}$ \\
\hline$\Uparrow$ & $\mathbb{1}$ \\
\hline Projeção de Finalidades & - Objetivo \\
\hline Formas de Mediação & $\begin{array}{l}\text { - } \text { Metodologia } \\
\text { - } \text { - } \text { Rempo } \\
\text { - Avaliação } \\
\text { - Tarefa } \\
\text { - Observações }\end{array}$ \\
\hline
\end{tabular}

Uma única aula (ou conjunto de aulas) pode ter este conjunto de elementos repetidos diversas vezes, de acordo com a estimativa de tempo disponível.

\section{Assunto}

Indicação temática a ser trabalhada em sala de aula.

\section{Necessidade}

Explicitação das necessidades percebidas no grupo e que justificam a proposta de ensino. Numa primeira elaboração, o professor pode entender que o Objetivo já 'incorpora' a necessidade; no entanto, o esforço para sua elucidação é salutar em nome da clareza que vai se ganhando (aproximações sucessivas). 


\section{Objetivo}

Trata-se aqui da explicitação do Objetivo Específico do ensino daquele assunto. Tem a ver com o sentido do ensino deste determinado conteúdo, para este grupo, neste momento (o que eu quero mesmo com esse trabalho?).

\section{Conteúdo}

Explicitação do conteúdo a ser trabalhado. Pode ser mais ou menos detalhado, de acordo com o conhecimento do professor; quando o assunto é muito conhecido e já trabalhou várias vezes sobre ele, basta uma referência para a memória. Quando o assunto está em pesquisa, em processo de elaboração, quando a síntese não está suficientemente construída, é importante que o conteúdo seja mais detalhado (até como uma forma de ajudar a configurar esta síntese).

\section{Metodologia}

Explicitação dos procedimentos de ensino, técnicas, estratégias, a serem utilizadas no desenvolvimento deste assunto; é o caminho concreto a ser trilhado. Pode indicar tanto as atividades previstas para o professor, quanto as esperadas dos alunos.

\section{Tempo}

Previsão do tempo a ser empregado com este assunto (quando - no sentido de duração; em relação ao sentido de ordem, já se manifestou antes pela seqüenciação dos conteúdos). É claro que se trata sempre de uma estimativa, mas é importante para a viabilização da proposta. A previsão do tempo revela também a prioridade dada a cada parte.

\section{Recursos}

Cabe aqui a indicação dos recursos que serão utilizados. É importante não desperdiçar oportunidades de inclusão de recursos. Se o professor não planeja e só se lembra quando a aula está em andamento, não dará para aproveitar mais a idéia, pois não preparou o material (ex: texto, recurso audiovisual, material ou condição para aplicação de uma técnica, etc).

\section{Avaliação}

Explicitação de como este trabalho estará sendo avaliado (que necessidades como vai indo): que estratégias o professor pode estar utilizando em sala para acompanhar o processo de desenvolvimento e de construção do conhecimento do aluno. A partir da avaliação feita têm-se elementos para replanejar o trabalho. 


\section{Tarefa}

Indicação das atividades que serão propostas para serem feitas fora da sala de aula. Deve estar relacionada aos objetivos trabalhados ou aos que serão trabalhados logo na seqüência. Numa perspectiva interacionista, a tarefa tem como funções básicas:

- O aprofundamento e síntese do que está sendo visto em classe;

- Ajudar o aluno a ter representações mentais prévias disponíveis correlatas ao assunto a ser tratado nas aulas seguintes. Desta forma, através da tarefa, o aluno planeja sua participação na aula.

\section{Observações}

Registro do professor sobre o andamento cotidiano do trabalho: o que fez, como fez, o que estava previsto e deixou de fazer, comportamento de aluno ou da classe que chamou a atenção, etc. Pode anotar aqui sua reflexão e avaliação sobre a caminhada, tornando o projeto um instrumento de pesquisa sobre sua prática: o que deu certo, o que não deu, as dúvidas e certezas que surgiram, suas hipóteses. É preciso resgatar este hábito de escrever sobre a prática (Diário de Bordo), tendo em vista a possibilidade de uma reflexão mais sistemática.

\section{Referências Bibliográficas:}

GANDIN, D. e GEMERASCA, M. P. Planejamento Participativo na Escola. O que é e como se faz. São Paulo: Loyola, 2002.

MENEGOLLA, M. e SANT'ANNA, I. M. Por que planejar? Como planejar? Currículo - Área - Aula. São Paulo: Vozes, 1996.

VASCONCELlOS, C. S. Planejamento: Projeto de Ensino Aprendizagem e Projeto Político-Pedagógico, $11^{\mathrm{a} e d}$ ed São Paulo: Libertad, 2002. 


\section{ANEXO 3. TRANSCRIC̣ÃO DA INTERVENÇÃO SOBRE PLANEJAMENTO}

P. A primeira pergunta que eu queria fazer para vocês, e agora quero que vocês socializem essa idéia, é se é necessário planejar ou não planejar o ensino? O que vocês acham que é necessário? Ou vocês fazem como uma atividade burocrática? Por que muitas vezes a gente vê o professor preenchendo um formulário, copiando do ano passado entregando e nem tem esse planejamento para acompanhar durante o ano.

M3. Eu acho muitas coisas disso tudo que você está colocando aí. Tem alguns momentos em que a gente até pensa nessa parte burocrática, porque na realidade ninguém sabe planejar, se tem lá uma série de idéias, mas planejar mesmo... Com relação ao planejar, eu acho que não é só planejar o ensino, eu acho que tudo a gente tem que planejar. Agora, a gente está vivendo uma época em que a gente não tem aquela, como é que se diz, a gente sabe exatamente tudo que vai acontecer. A gente está vivendo um momento muito instável. Eu acho que mesmo dentro da instabilidade a gente tem que ter mais ou menos idéias do que a gente vai fazer e do que a gente espera aprender. Pelo menos a gente está fazendo isso agora, ou pelo menos tentando aprender isso agora. Porque eu não consigo comandar nada nem ninguém. Na realidade é isso. Então eu preciso aprender a planejar para saber como isso vai ser possível executar. Mas em que momento isso não foi possível? Como eu posso contornar? Porque como eu sou muito autoritária eu acho que posso mandar em tudo e em todos, e não é assim que a gente consegue, porque daí se a gente planeja dissecando, fechando tudo, a gente acha que vai dar tudo certinho. Então, hoje eu dou um passo até aqui, amanhã eu dou passo até ali, só que aí a gente tem que pensar que eu posso dar esse passo ou tentar dar, e se não for possível dar esse passo, porque não foi possível. E eu acho que essa ação, quando você planeja, você tem que estar aberto para enxergar isso e contornar essa situação, então eu acho que planejar não é só no ensino, é planejar o dia-a-dia e planejar a médio, a longo e longuíssimo prazo e contornar as situações na medida da necessidade. Eu estava lendo uma coisa no final do ciclo, o diário de bordo, que inclusive eu acho uma coisa extremamente legal de a gente fazer. Eu tinha pensado em uma determinada turma do LabVirt, escolhi uma turma para fazer um diário de bordo, para a gente poder ler essas ações e enxergar isso, não dá para fazer com todos porque fica difícil. Não sei que tempo exatamente, mas eu acho que é essa finalidade que a gente tem que pensar, porque na hora que você levanta você já planeja o seu dia. Você já levanta e já pensa "bom hoje eu vou à escola, da escola eu preciso ir ao banco, do banco vou passar no supermercado..." e chega ao meio do dia você replaneja. "Bom, não vai dar para eu ir ao banco porque eu esqueci o cartão de crédito do banco, ou porque a 
hora..." Enfim, você vai fazendo isso automaticamente, só que a gente precisa. Eu sinto isso na minha pessoa, por que não ter muitas informações sobre planejamento bibliograficamente, é uma coisa muito mais subjetiva, ou talvez uma coisa que eu aprendi ao longo de experiência. Mesmo quando estudante você pára e pensa "para que eu vou planejar se eu não consigo medir depois o resultado desse planejamento, e se eu medir e a ação não adiantou nada?" Porque, por exemplo, eu posso depois chegar à conclusão que aquela classe não foi aplicada o suficiente naquele trabalho, mas isso não acontece absolutamente nada, tanto faz se deu certo, se não deu certo educacionalmente falando. Dentro daquilo que eu estou falando de escola estadual, ou dentro de escola particular ou de determinadas escolas, das escolas pelas quais eu passei.

\section{P. Mas você diz assim que não adianta planejar porque não tem como avaliar?}

M3. Não. Não é que não adianta planejar, mas é que muitas vezes a gente fala que eu vou planejar burocraticamente porque se eu planejar que vou dar Química geral, se eu der ou não der, não vai acontecer absolutamente nada Se eu der e os resultados forem negativos, também não vai acontecer nada. Eu particularmente posso chegar e falar assim "estou cometendo algum engano, alguma coisa que aqui no meio do caminho ficou meio perdida, vou resgatar algumas coisas", mas o que eu quero dizer é que na escola você só faz isso burocraticamente, você entrega e está acabado. Entrego e beleza. Não tem suporte de ninguém, ninguém te dá um apoio, ninguém te dá um acompanhamento, você tem um coordenador que é professor de português de primeira a quarta série. Então não tem a menor idéia do que é Química. Ele teve lá atrás, então não pode te ajudar em projetos, em novas técnicas, estratégias. Então, fica todo mundo assim "Ah vai ler, vai estudar..." Bom, eu sei que eu posso ler e posso estudar, não precisa ninguém me dizer., mas cadê o tempo para fazer tudo isso? $\mathrm{E}$ aí depois acontece o seguinte, eu chego e falo "Eu estou tendo este problema com a classe, ou este..." Por exemplo, o ano passado eu não dava aula de sexta-feira, não porque eu não tinha aula, mas porque eu não tinha aluno, e passou o ano inteiro, eu cheguei ao ponto de não entregar as notas dos bimestres para ver se alguém falava alguma coisa, fazia alguma coisa comigo, ou diretor ou coordenador, enfim que ação nós vamos tomar, que estratégia nós vamos fazer? E não aconteceu absolutamente nada. Eu tive que chegar para a turma de sexta-feira e propor alguns paliativos ali para conseguir, e dissolver, diluir essas notas ao longo do ano para conseguir promover esse aluno. Primeiro bimestre porque era primeiro bimestre, segundo bimestre porque era segundo e assim por diante. É isso que eu estou querendo te dizer. Então, para que a gente vai planejar? Eu planejo, eu não precisaria estar entregando esse documento, eu entrego porque o meu 
coordenador pede, eu planejo para minha ação, porque eu preciso ter na mente que andamento eu vou ter, e ao longo do período. Eu vou checando algumas coisas que eu vi ser importante, mas na realidade falta tudo isso que eu estou te falando, falta conhecimento teórico da minha parte, falta como é que eu vou perceber que as minhas ações estão adequadamente planejadas, o que eu posso... Eu percebi que não deu certo, mas aonde eu vou achar um caminho para melhorar? Eu acho que essas coisas basicamente todos nós sentimos, ou pelo menos eu considero. Não sei se é o que vocês consideram...

M7. Eu concordo com o que você disse em gênero, numero e grau, só que eu contestaria uma coisa, você estava enxertando durante anos e tirando né?! E chega uma hora que é tanto projeto... Que nem no ano passado. Todo mundo ficou preso no campeonato bem na hora que a gente estava apresentando, e no nosso era igual, e naqueles projetos da Secretaria da Educação que você é obrigado a fazer, não está escrito em nada da proposta da escola mas você é obrigado a fazer. Aí você é obrigado a tirar coisas que você julga importante porque você planejou, e aí você tira coisas porque agora já não é tão importante, mas não é importante por causa do ritmo de andamento e de conteúdo e de proposta de Química. Deixa de ser importante porque não vai dar tempo, e avaliação diagnóstica a gente até faz, mas você começa a aplicar e aí você pára, porque eu não consigo resgatar todos os alunos que estão apresentando dificuldade. Todos, 20 a $30 \%$ pelo menos. Essa é a realidade que eu vivencio...

M3. É que na realidade eu acho que as coisas são um pouquinho mais confusas. Eu, por exemplo, quando eu entro para falar, para dar o ar, por exemplo. Tem que falar em porcentagem das substâncias que fazem parte do ar. Ficam assim te olhando. Então você tem que parar e explicar o que é, mas isso não está no planejamento, embora eu saiba que exponencialmente a matemática aumenta o número de aulas e a Química diminuiu exponencialmente. Mas, o trabalho dos matemáticos continua a desejar. Me desculpe se tem aqui algum professor de matemática, mas eu não sei onde é que é a falha. Se é o aluno que não esta estudando, não sei se o aluno que não esta sendo cobrado, enfim eu só sei que eles estão vindo cada vez mais com mais dificuldades, e a Química que eu acho que usa português, matemática diretamente e física muitas vezes, não esta conseguindo dar conta de todos os conteúdos. Então você começa a selecionar, é uma coisa que eu nem escrevi aí na hora mas agora falando veio na minha cabeça. Você muitas vezes começa a selecionar, um dos fatores é esse "bem eu não vou dar isso porque tem todos esses pré requisitos que eu sei que eles não tem, e nem eu tenho tempo prá parar e resgatar essas coisas". Um exemplo, o meu curso do noturno no 
ensino médio está com uma aula, então veja, se já com duas já estava difícil, se as sextas-feiras praticamente encerro as semanas na quinta e agora só tem uma aula por semana, então você imagina o quê que acontece. Então o meu objetivo, para o meu planejamento, para mim se ele sair de lá saindo um pouquinho como cidadão e enxergando que algumas das coisas que a gente fala são importantes para que eles decidam o futuro deles e do país eu estou satisfeita. Então, aquela coisa que eu entrei há um tempo atrás que a gente tinha 3, 4 aulas por semana por sala, não 3 ou 4 aulas por semana por grupo de série, então o que a gente dava lá, pegava o Feltre (livro didático) e tentava ir de cabo a rabo hoje nem pensar, eu não tenho como seguir esse tipo de... eu não tenho, se os colegas tem parabéns porque...

M1. Não tem como mesmo, mas é aí que a gente tem que pensar no seguinte, tem muitos casos, por exemplo, o da Ana, tem uma turma com uma aula por semana, eu vou ter que fazer o quê? Fazer uma previsão de necessidades dessa turma, eu vou prever a necessidade que ela tem. Fazer uma seleção de conteúdos para essa necessidade, prevendo o tempo que eu tenho, os recursos disponíveis que eu tenho naquela escola, tudo isso eu vou ter que pensar logo no inicio do ano ver a situação, aquela avaliação diagnóstica de conhecimento dele mesmo prá também não vir tentar fazer grandes coisas e aí parar porque viu que não vai mesmo, então tudo isso são coisas que a gente tem que estar pensando no momento da avaliação com etapas bem definidas do que a gente quer, e sem esquecer do momento de avaliação para ver se o que eu pensei está de acordo, está dando certo ou não, onde eu errei, o que aconteceu, para eu replanejar isso de novo.

M2. Está certo, mas olha, não sei os colegas, mas faz muito tempo que eu não penso em grandes coisas.

\section{M1. Não dá mesmo}

M2. Não porque precisaria de grandes coisas...

M1. Às vezes eu tenho até vergonha de mostrar o meu planejamento, é verdade, eu tenho até vergonha de mostrar o meu planejamento por conta da...

M2. Não tenha é aquilo que você pode fazer.

M1. ...qualidade e da quantidade daquilo que a gente quer fazer. 
M2. Como assim? Tem que colocar aquilo que você pode fazer.

P. O que eu quero, eu gostaria que isso acontecesse com vocês, ao longo do curso, que a gente não fizesse mais, os professores tem que pensar nisso, não fazer mais o planejamento só para a escola ver para ter lá, e alguém chegar lá e falar assim “ Oh ele está dando o curso inteiro, o Feltre inteiro..." Mentira. Então, nós temos que planejar dentro da nossa realidade mesmo, e não se importar se alguém chegar lá e dizer "Você só vai dar transformações químicas o ano inteiro?" "É porque é o que eu consigo fazer com uma aula por semana" então nosso planejamento tem que ser real e tem que ser um apoio para o nosso trabalho, e não virtual para todo mundo ver e falar que aquilo lá está pronto, esquecer de fazer o planejamento para entregar para a escola. A gente tem que fazer o planejamento porque é uma necessidade do ser humano, como ela disse a gente planeja o nosso... A gente acorda planejando, a gente planeja o dia inteiro, então porque eu não vou planejar a minha ação no meu trabalho para que ela saia o mais satisfatoriamente possível.

$\mathrm{O}$ que o planejamento requer que a gente tenha em mente quando a gente vai planejar? O conhecimento da realidade, as necessidades que aquela turma tem, que aquela escola tem. Então, eu preciso conhecer a realidade daquela comunidade que eu trabalho. Eu preciso definir objetivos claros e... objetivo mesmo, objetivos pontuais que eu consiga... Que são coisas que são possíveis de ser realizadas. Determinar os meios que eu tenho, os recursos disponíveis que eu tenho. Então, em alguns momentos a gente vê assim "Ah eu vou usar a sala de informática". Tem professor que chegou hoje na escola e não conhece a escola ainda, mudou o ano, e ele fala que vai usar a sala de informática mas não viu se a escola tem sala de informática ou não. Então ele prevê aquilo no... e quando ele vai usar não tem o computador funcionando, então aquilo que ele planejou já não vai funcionar, ele vai ter que pensar em outra estratégia e isso acaba atravancando o trabalho dele. Às vezes ele fala "Temos uma sala de informática" chega e bate na porta e não tem a chave, então são coisas que a gente precisa já antes, nesse momento do planejamento estar rodando a escola e sabendo tudo que eu tenho dá para usar? Está aberto? Está tudo funcionando? Então eu posso prever isso no meu planejamento. Princípios de avaliação e critérios de avaliação isso tem que estar sempre claro para vocês e para o aluno, para que ele não tenha medo dessa avaliação, pensar nessa avaliação como... completa e não só aquela avaliativa mesmo, aquela antiga que a gente tinha, então essa ter todas as formas e essa avaliação ser acordada com os alunos "Entenderam? Assim está legal? Então o que vocês acham?..." Então esse planejamento também faz parte, precisa da participação do aluno, para ele ter claro o que vai ser o trabalho dele também no ano todo, não ser sempre uma surpresa, é horrível para o aluno 
também ter essas incertezas. Prazos e etapas para execução, então eu preciso colocar que aquilo tem que ser em um mês, se não a gente passa dois três meses em um assunto só, e a gente não tem tempo para isso, então por isso que é melhor selecionar bem aquilo só que você quer e conseguir fazer aquilo bem feito, em vez de quantificar tanto e não fazer nada, eu querer um monte de conteúdo, mas eu não chego a lugar nenhum com esse monte de conteúdo, se eu selecionar um e saber que ele saiu dali com este um, ver que ele aprendeu aquele um, nossa é uma vitória pro professor, eu acho, ver que ele aprendeu aquilo que ele tentou ensinar. Agora prevendo muitas coisas a gente não consegue mesmo. Possibilitar reflexão que é aquilo que ela falou parar, pensar avaliar, deu certo? Não deu certo? Ver aonde será que embolou o meio de campo? Aonde será que eu preciso mudar? ... Então esse momento de reflexão é importante, se ela for coletiva é melhor ainda, porque aí a gente tem apoio de outras idéias, de outras pessoas, e eu acho que até um professor de primeira a quarta pode te ajudar, não na seleção de conteúdo talvez, mais em algumas estratégias, prá dar uma saída num entrave que você teve, depende do problema é claro, mas não assim "Ah como eu vou conseguir ensinar termodinâmica pro meu aluno?" Isso ele não vai conseguir te ajudar mesmo, mas em algumas estratégias de ação com o aluno talvez ele possa.

M1. O que eu levantei nesse sentido, é porque eu acho que o ideal seria você ter um coordenador da área ou o mais próximo da área possível, porque eu sei que o Estado acaba sempre falando naquelas coisas, a gente não tem recursos então acaba pegando um coordenador, uma pessoa que se disponha a ser coordenador, e prá coordenar todas as áreas, e além de tudo existe todo o lado burocrático que tem que cumprir... ou seja, o coordenador pedagógico acaba não dando todo o suporte pedagógico que a gente precisa, então é nesse sentido, eu não estou menosprezando o fato de ele ser de primeira a quarta, mas é que o enfoque dele é outro, ele até tem estratégias que vão me ajudar com certeza, mas especificamente para minha área, ele vai ter essa estratégia, então eu acho que a gente devia.... não sei.... pensar em alguma coisa que até fosse mais viável nesse aspecto, um coordenador pedagógico prá todas as disciplinas... coitado dele, pensando nele, não é... no apoio que ele pode dar a todos, sem contar a parte burocrática, que ai eu já nem vejo mais a coordenadora...

P. Outra coisa ele favorece a pesquisa na sua própria prática, então nessa questão de pesquisa, quando você faz uma avaliação você levanta dados daquele seu processo, então é essa pesquisa que a gente fala, então é essa pesquisa de você estar colhendo dados da sua prática, prá poder interferir nessa sua prática também. Organizar adequadamente currículo, a gente tem essa mobilidade na escola estadual de mexer no 
currículo, o quanto vocês querem, então adequem o currículo às necessidades dos alunos de vocês, às vezes não tem tanta importância ele aprender pilha vai, então o que é mais importante para essa comunidade nesse momento, que está acontecendo nesse momento que é mais importante, o que eu posso colaborar prá ele ter o conhecimento e ser um cidadão e ... Comunicação com os outros professores no momento do planejamento, a idéia é essa, que ele seja participativo, tanto com os professores e também com os alunos, é aquilo que eu falei prá vocês a participação deles é importante, assim vocês tiram até desejos que eles têm, às vezes sai até coisas mais interessantes...

M1. Nessa hora do trabalho coletivo, é justo nessa parte que o coordenador não conseguiria estar agindo, os outros professores com as mesmas dificuldades poderiam inclusive assim, o professor de física dá aula uma vez por semana, o de Química dá aula uma vez por semana, o de biologia... aí de repente mesmo nessa coisa que pode ser um projeto qualquer, que veio da secretaria, "Ah então eu vou fazer esse projeto, eu vou trabalhar só ligações químicas que ajuda em biologia, biologia eu vou fazer isso..." de repente vai surgindo, não sei, mas isso daí o que acontece, no horário do trabalho coletivo consegue um pouco disso, óbvio se o coordenador não ficar falando outras coisas e desvirtua a reunião, mas se fosse possível aproveitar os professores e ...

M1. Na realidade se você for ler os parâmetros curriculares é exatamente isso, por que que eles falam lá que a gente deve ter até quatro aulas prá se estudar currículo? Porque seria exatamente uma área suprir a outra, uma área complementar a outra, só que a gente não consegue... ninguém... pelo menos eu estou falando da minha escola, a gente não senta com o professor de biologia e fala "o que você vai dar?" Mesmo porque a gente também não abrange... eu tive uma vivência, eu tive uma experiência em termos de estudante, eu aprendi Química, então eu lembro da biologia quando eu fui aluno lá do ensino médio, então eu não sei da biologia o que ela precisa de treinamento para eu poder ao invés de dar... então eu entro com ligações porque vai ajudar, eu entro com química orgânica porque vai ajudar, se percebe isso, a gente na realidade não senta para fazer esse grande planejamento, e o que acontece, eu dou aula de Química estou falando sobre $A$, ele dá aula de biologia está falando sobre A, o outro professor da aula de física está falando sobre $A$, no fim a gente está falando a mesma coisa, em três rituais diferentes, quando de repente a gente podia estar falando A, ele B, e tantas outras coisas e estar suprindo todo o conteúdo na realidade, essa é minha visão, então eu acho que falta isso. 
M1. Até porque, quando a gente tem o tempo do planejamento no início e no meio do ano, que seriam os dias que se tem mais tempo para isso, eu acho que se perde muito tempo com discussões que não levam a nada, então discute-se muito o sexo do anjo e a gente não tem tempo para realmente fazer aquilo que a gente gostaria, aí por exemplo, a gente tem professor de Química que tem três na casa, professor de biologia tem cinco, um dá aula para duas salas, outro dá aula para três salas, o conteúdo não bate em nada, aí vem outro que é de lá não sei aonde e... então tudo isso, a gente teria que ter esse tempo para gente se acertar, e no fim a gente não tem o tempo, porque começa a tal conversa que não leva a nada, então a gente fica sem esse tempo, porque depois tem aquele professor que só dá quatro aulas na escola, eu vejo ele na hora do intervalo uma vez por semana, um intervalo de quinze minutos e não dá nem para falar oi para ele, então aí a gente não consegue mais sincronizar as coisas aí cada um vai por si e pronto.

M1. Pela primeira vez nós fizemos na minha escola uma avaliação diagnóstica para saber que tipo de regras a gente colocaria, porque lá nós temos um problema muito sério de regras, disciplina, regulamentos etc, então lá foi feita essa pesquisa, todos se envolveram, pela primeira vez, mais aí foi tirado dos professores, os professores que resolveram fazer isso, "então vamos fazer, porque a gente precisa saber, porque a gente quer..." como entro a partir de agora o censo dos colegas então a gente tem que entrar sete horas de manhã, então a gente queria saber que espaço de tolerância deveria dar para esse aluno, se até sete e dez, se até sete e quinze... para saber como é que eles chegariam, essa foi uma das perguntas que foram feitas, mas foi a primeira vez, então a gente não tem esse perfil do aluno, para saber assim... da minha parte é tudo muito meio que subjetivo, é tudo meio que intuitivo, é meio que nessas pesquisas feita na boca de urna, "Ah você vem de carro? Vem de ônibus? Vem de não sei o que? Estuda? Trabalha? Só estuda? Lá lá lá..." não é como se diz... documentado isso, e pela primeira vez foi feito isso. Então acho que na realidade a gente é muito amador.

M2. Teve uma hora Marcela que você falou sobre a necessidade de adequar o currículo e vê a necessidade do aluno, o que eu vejo na minha escola é assim: de tanto aumentar a carga de português e matemática, os alunos querem fazer direito, comunicação, jornalismo e só, acabou com a área de exatas, alguns ainda arriscam alguma coisa na área de biológicas, biomédicas, alguns, muito poucos, mas a maioria está na área de humanas, vai para área de humanas, porque aumenta, aumenta, aumenta o número de humanas, então a gente fica adequando o currículo, adequando a nossa disciplina o nosso conteúdo e a gente percebe que cada vez mais ele estão sendo 
desmotivados a seguir a área, apesar deles acharem assim "Antigamente o meu pai falava que Química era mais difícil do que é hoje..." claro, tem muito menos conteúdo, e eu acho que a gente também evoluiu um pouquinho na forma de ministrar as aulas, mas o conteúdo também diminuiu muito, então eu fico adequando o currículo para escola e eu não sei se isso é o caminho, porque o que a gente está vendo é um menor número de profissionais da área, cada vez mais difícil de encontrar profissional da área, cada vez mais difícil de ver um aluno falando assim "Oh vou fazer Química", no começo eu tinha vários alunos falando "Oh professora eu vou seguir Química" hoje eu tenho dois, três alunos da escola, de mil e seiscentos alunos eu tenho dois ou três...

\section{M1. E a gente fica tão feliz né?}

M2. Eu acho que na realidade o sistema é mal organizado, porque os projetos que vêm no decorrer do ano nós já deveríamos saber no começo do ano, pra poder fazer o nosso planejamento e na verdade a gente não sabe, eles surgem ao decorrer do ano, então de repente você está dando uma coisa, você tem que parar porque tem que realizar o projeto, então já vem do sistema já esse mal planejamento...

M1. Mas é muito importante saber se vai deixar aluno usar boné ou não na sala de aula.

P. Não dispersar atividade e oportunidade de aprendizagem, então se você já prevê uma atividade que está mais fácil, porque às vezes você está no meio de uma situação e fala "Ai aquele texto ia tão bem aqui agora, mais eu não tenho texto", ou aquela fita que iria tão bem, então isso é muito importante para você prever as suas atividades. Ser um elemento de auto formação do professor, porque você vai parar vai refletir, você tem que pesquisar outras estratégias, outras formas de você estar chegando ao aluno, então você estar estudando de uma certa forma. Resgatar o saber docente, a cultura pedagógica, e superar essa pressão que o professor é submetido em relação à concepção e o domínio do seu perfazer, quando ele diz assim que oh ... nesse sentido aqui que as coisas vem prontas para gente, o professor sabe fazer, ele não precisa que isso venha de cima, venham essa imposições às vezes e o professor acaba ficando fechado lá, nessas propostas, você tem essa liberdade de querer mexer nisso, fazer como você acha, não se fechar ao livro didático somente, fazer de uma forma que você acaba ficando preso naquilo, então ele desapropria o seu conhecimento não vê o professor como um ser pensante, que ele mesmo pode construir o currículo dele, que ele mesmo pode fazer essas apostilas que hoje a gente tem no ensino, então o professor 
pode estar sozinho pensando nisso, com a turma dele com a realidade que ele tem. Quais são as questões importantes que a gente tem que pensar no momento do planejamento? Porque eu vou ensinar Química? O objetivo do meu ensino? Para que? O que eu quero que isso desenvolva no meu aluno? Para que? Para quem? Quem é o meu aluno? Quem é a minha clientela que eu tenho? Então eu preciso pensar nisso. O que eu vou ensinar para ele? O que eu julgo interessante ensinar para ele? E como vou ensinar isso para ele? Que estratégias eu vou utilizar para que ele aprenda aquilo que eu estou tentando ensinar prá ele. Algumas questões que a gente sempre tem que pensar, para gente poder se nortear dentro de vários fatores. Dentro do planejamento maior que a gente faz anual... É o que/fazer cotidiano dele, o dia-a-dia dele, no início eu planejo um tema, mais depois eu tenho que destrinchar esse tema, como é que eu vou agir lá na sala de aula naquele dia, isso muitas vezes a gente faz indo prá escola, no carro "eu vou dar aquele texto no começo, depois eu vou aplicar aquele questionário" às vezes a gente não tem nem registro mais, você planeja isso antes com certeza, você não chega na sala e pensa no que vai dar hoje, na sala, na frente do aluno, jamais, então a gente tem o costume de fazer isso, só que às vezes a gente não tem o costume de registrar isso, e o porque é importante fazer o registro? Para depois eu poder avaliar e ver o que deu certo e o que não deu, para eu poder replanejar isso em algum momento, porque se eu não faço isso no ano que vem eu repito isso, aí erro de novo e repito e nunca paro para pensar porque eu erro naquilo, fazer uma reflexão da minha prática. Então eu coloquei aqui algumas dimensões e elementos que são necessários no plano de aula, uma proposta, nada é fechado. Cada um pode adequar o seu da melhor maneira, eu quando comecei a dar aula eu recebi aquele formulário da escola, objetivo, metodologia, recurso e avaliação, um papelzinho desse tamanho, para eu planejar o meu curso inteiro em quatro coluninhas, que depois eu mudei e fazia pelo menos uma folha, e entregava uma folhinha de quatro folhas para escola, porque a escola dá esse formato para você, mas você tem a liberdade de mexer nisso o quanto vocês querem.

M2. Na minha não tem, você pode usar um pouquinho mais de espaço mais tem que estar naquele... porque inclusive dessa vez eles deram... ela já entrou no... já fez a planilha já copiou no meu disquete, que é para eu entregar para que ela passe para o computador na hora de fazer o plano anual, eu não sei tem o nome... sei lá plano diretor, não sei uma coisa assim qualquer que... essa parte burocrática... daí o que ela faz ela já pega e já insere lá, porque quando o professor não faz isso só faz essa folhinha eles tem o trabalho todo de digitar, o que também elas têm que padronizar essa entrega prá diretoria, então... 
P. - Então eu vou te dizer como funciona, é porque elas quiseram dessa maneira, porque ela pode simplesmente anexar tudo e encadernar tudo junto do jeito que o professor entrega, eles querem fazer tudo bonitinho...

M2. Exatamente, neste caso é o que eu estou te falando, nesse caso não adianta, se eu chegar e falar está aqui o meu planejamento, porque eu particularmente, eu prefiro planejar aula por aula, porque quando a gente tinha um outro tipo de módulo, que era um outro tipo de curso que a gente trabalhava quatro aulas no semestre, que eu dava um semestre só de Química, que no semestre que vem ele ia para outra área especializada, então eu fazia por aula que eu achava muito mais prático, aí elas resolveram fazer desse jeito, então, aí já te deu o disquetizinho, "olha está aqui você preenche" é lógico não fala assim você só pode gastar uma planilha, mais você tem que procurar trabalhar nesse número que a gente fechou, especificamente nesse.

M5. Uma das justificativas que existem para isso, já escutei alguns colegas falando, que tem trabalhos nas diretorias de ensino, no caso de Mauá, é que sabe que o plano que o professor entrega ele não cumpre, então ficam um monte, uma papelada inteira lá perdida, já sabem que ele não vai cumprir mesmo, segundo essas pessoas, pedem o mínimo dele lá e pronto, do ponto de vista legal tem um plano, não vai ter problema algum e do outro ponto de vista eles não vão ter muito trabalho também.

M4. Quer dizer o professor tem que fazer dois planejamentos, um para entregar e um paracumprir.

P. A idéia então é que se faça isso, já que prá escola não funciona muito, a gente entende que planejamento é uma ferramenta minha de trabalho, então eu vou fazer uma para mim bem feita e organizada para eu organizar o meu trabalho ao longo do ano.

M4. Caixa dois.

P. Ai a gente resume para entregar para escola, dá uma resumida.

M2. Sem contar que na escola eu tenho três turmas uma que vem para completar cargo e num sei o que então no meu caso, que nós somos em três professores de Química, cada um vai fazer o seu planejamento, porque a professora que dá aula comigo nos segundos anos, que a gente divide a turma, não concorda com a forma que eu trabalho e obviamente que eu não vou concordar com a forma com que ela trabalha. 
P. Aí o aluno é remanejado prá um outro ambiente, aí ele joga fora o caderno de dois meses e faz outro...

M2. Mesmo porque quem tá de manhã e vai prá noite, ele passa de duas aulas e vai prá uma aula, e assim vai, quando chega prá fazer esse tal documento, ele tira aquele que tiver mais informações, então se o meu planejamento for com mais itens insere ali, e só o dela for com menos itens "Ah, não está muito resumido, muito enxuto".

M4. A questão é aquele burocrático, aquele que a gente tem que fazer tem que entregar enfim, o coordenador ou o diretor quer que faça no Word letra arial 12 e num sei o que, tá bom, é aquela exigência burocrática que a lei????? Uma estrutura que não funciona que tá lá prá mostrar e juntar papel num sei porque, mas eu acho que tudo que a Marcela tá colocando é a gente ter em mente que precisa ter o nosso, a nossa prática, a nossa questão, e aí aquelas quatro coluninhas lá, pode ser uma só, pode ser duas, três, você é que vai ver o que realmente é importante, se vai ter coluna se não vai, e é isso que a gente tem que olhar, sabe porque se a gente ficar nesse de que a escola exige, e estamos amarrados né, tá preso e aí o que eu faço? Eu não sei. Então a gente tem que transcender isso "Tá bom aquilo ali eu faço porque tem aquela exigência" mas vamos tentar um planejamento que vai me dar uma prática melhor, que vai me ajudar, que vai... e aí eu vou fazer do jeito que eu quiser, pode ter vinte páginas, uma, dez, sou eu que vou resolver, é a hora de a gente ter a liberdade de "eu quero fazer assim, esse sou eu de verdade, o outro é o que mandam eu ser".

M1. Lá na nossa escola o planejamento já é totalmente diferente disso, já vai resolver, nós não colocamos mais objetivos e estratégias, é competência e habilidade, é tudo em cima de competência e habilidade e tem o conteúdo, então ele é extremamente "dável", a frase que eu coloquei serve pro primeiro, segundo e terceiro ano, então dei, bem, se não dei, bem, entendeu ele é vago então é assim, eu não posso modificá-lo, ele encosta no plano diretor, e o plano diretor só pode ser modificado a cada quatro anos, e já é um absurdo, porque quatro anos pro ensino fundamental é de quinta até oitava, mas quatro anos pro ensino médio é de primeiro até primeiro da faculdade, então eu volto lá na faculdade prá corrigir, então fica totalmente jogado, sem sentido algum, burocrático, vamos fazer, vamos, tem que fazer, vamos, o que eu posso fazer é uma adequação, na hora de eu fazer essa adequação é aquela história "Ah, você não deu idéia... vamos fazer uma avaliação diagnóstica prá saber como eles estão... vamos fazer uma revisão.. foi dado o dever..." o que eles cobram da gente é diferente daquilo que a gente se propõe a fazer, é completamente diferente, e se você não faz, você é cobrada porque você não 
fez, o tempo inteiro é assim. Que nem você falou "É então eu só vou colocar isso no meu plano" eu só vou colocar isso no meu plano e o aluno vai chegar cobrando porque ele lá no cursinho tão falando isso e eu não tive isso aqui na escola, e ele vai cobrar na coordenação e na direção, e a coordenação e a direção vai falar porque você não colocou isso no seu plano, "porque eu não tenho condição de dar", "O que, como não professora?" todas as escolas eu não digo, mas pelo menos lá a nossa realidade é essa.

P. O que nós temos que pensar em plano de aula, na apostila de vocês, vocês tem o planejamento todo, um roteiro também de planejamento geral, mas eu foquei no plano de aula que é o que vocês tem que sair daqui mais ou menos elaborado por causa do LabVirt tá. Quais são as dimensões que eles colocam, análise da realidade, a projeção de finalidades e as formas de mediação que eu vou utilizar, então como eu vou analisar a realidade é o assunto que eu vou tratar, é o tema que a gente coloca lá, e quais são as necessidades em relação a esse tema, porque eu vou trabalhar esse tema, qual a necessidade de trabalhar esse tema, tem que pensar a importância dele, ele é necessário por causa disso e disso. A projeção de finalidades é o meu objetivo claro, é um objetivo claro e possível, certo então eu tenho que ter um objetivo final desse trabalho, e a avaliação vai ser em cima desse meu objetivo, qual foi o ponto que eu alcancei, quais foram as minhas formas de mediação que não deram certo, que não me permitiu alcançar o objetivo que eu queria. Então quais foram essas formas de mediação, a metodologia do objetivo que eu vou utilizar, como é que eu vou trabalhar, o tempo que eu tenho, então nós vamos colocar lá duas aulas de cinqüenta minutos, recursos que eu tenho prá mim, então considerar os recursos possíveis mesmo que eu tenho prá utilizar, avaliação, qual vai ser a minha avaliação sempre bem acordada com os alunos, algumas tarefas que eu vou ter que realizar durante o meu plano, por exemplo, as observações que são importantes prá mim durante o meu percurso, eu deixo um espaço no meu plano prá fazer observações, na aula um aconteceu isso e isso, algum comportamento de aluno, alguma coisa, prá você depois, porque às vezes acontece aquilo e você acaba passando com a correria que você vive você não pensa nisso, então é um espaço de registro do processo prá você ver depois o que aconteceu e replanejar, pensar novamente e refletir sobre aquilo. $E$ essas referências bibliográficas que vocês vão estar utilizando aí no trabalho, coisas que não vieram no primeiro planejamento, vou utilizar um texto, que texto? A gente gostaria de saber, como o Flávio cercou o cerco prá gente tá participando com vocês na escola, com o planejamento a gente precisa ter o planejamento na mão, prá nós é importante saber exatamente o que vocês vão estar utilizando prá gente poder subsidiar o trabalho de vocês... 
C. Só para lembrar, esse orientador pode estar fazendo aquilo que você falou no início, que o teu coordenador não dá conta de fazer, porque ele é de português, história, ensino fundamental... é exatamente isso, a gente pode até dar umas dicas, você está focando o projeto e naquele momento pelo menos você está sendo subsidiado, você vai ter alguém prá trocar uma figurinha ali, entendeu? Isso prá nós é importante nós termos, todo orientador, de você ter o planejamento geral de 2005 e o plano de aula, prá nós termos a idéia de na época que vocês vão estar trabalhando, quando, então assim no segundo bimestre vocês vão trabalhar termodinâmica e vão ter um plano, vai ter o LabVirt nesse meio, então até o segundo bimestre ele pode estar trabalhando com vocês outras... preparando essa atividade e aí ele já se organiza prá nesse segundo bimestre estar agindo lá junto com vocês na escola, então a gente tem mais ou menos um cronograma, tá, prá nós vai facilitar o trabalho também, alguém quer fazer alguma pergunta em relação a essas dimensões e elementos que a gente colocou aqui? Eu coloquei prá vocês aí o planejamento de uma aula, era até prá eu ter... eu já pedi permissão prá ele, mas era prá eu ter tirado o nome mas ele deixou, o Fábio que é o outro orientador que a gente tem aqui, que faltou hoje, "eu vou ser massacrado" ele falou assim prá mim, "eles vão me massacrar", falei que não, eu coloquei o planejamento dele, tá na pasta, e eu coloquei ele aqui prá vocês, prá gente analisar, prá vocês verem pontos importantes que ele colocou, e pontos que estão faltando, prá vocês poderem planejar o de vocês hoje, dar uma esboçada no de vocês... a Marcela quer que vocês deixem o esboço desse planejamento ... vocês precisam deixar hoje o esboço do trabalho de vocês, já até prá nós orientadores termos uma noção dos assuntos que vocês vão trabalhar, é lógico que isso não vai sair bonitinho e perfeito, vocês vão estar podendo mexer nisso em casa, mas a gente precisa ter uma noção de como vocês vão trabalhar. Isso vocês vão fazer ainda por uma hora, vocês vão poder até utilizar os computadores se vocês quiserem, prá já ir fazendo nos computadores, tem também os da outra sala que vocês vão poder estar utilizando. Bom então aqui nós temos o planejamento do Fábio e, vocês têm em mão aí, e eu queria que a gente desse uma analisada de como ele entregou esse planejamento, se tá fácil prá um orientador entender o que esta sendo feito na sala de aula, o que poderia ser acrescentado, o que não poderia, prá vocês poderem ter uma noção de como vai ficar o planejamento de vocês, tá? Bom ele deveria estar aqui, ele colocou que o público dele são alunos do primeiro ano de ensino médio, que a gente colocou lá nas nossas dimensões mais ou menos o que deveria ter, vamos seguir mais ou menos o quadrinho, se vocês quiserem seguir mais ou menos essas dimensões ela está na página oito, eu botei lá no plano de aula tem essa tabelinha anterior, e aí ele coloca o público, o assunto que ele vai traçar, os conceitos envolvidos, 
transformações químicas e combustão. E aí o que vocês acham dessa introdução do planejamento? Comprido? Falta alguma coisa? Ou esta ótimo desse jeito?

M4. Eu acho que ele deixou de colocar quais as necessidades, uma justificativa talvez do trabalho, porque ele escolheu combustão e não ligações químicas, porque ele achou importante... gente é assim, a gente tem que entender que o LabVirt é uma ferramenta prá fazer coisas ali que a gente não poderia fazer no dia-a-dia, às vezes um experimento muito simples de acrescentar uma substância e outra dá um resultado que eu consigo fazer em um laboratório, não é importante eu fazer isso visualmente se eu tenho condições de fazer isso na prática, eu vou passar pro LabVirt coisas que talvez sejam muito difíceis eu construir isso em um laboratório por exemplo, é aí que tá a utilidade da ferramenta, assim às vezes a gente enxerga modelos e fazer um desenho na lousa pelo amor de Deus o aluno não enxerga de jeito nenhum, então eu posso utilizar essa ferramenta prá mostrar esses modelos, movimentos, alguma coisa nesse sentido, então porque é importante eu colocar a combustão aqui, o que é importante nesse tema prá eu colocar no LabVirt, vocês estão me entendendo? Porque eu não posso explodir um laboratório, por exemplo, se eu quero que cause uma explosão então é bom colocar virtualmente, né, prá não acontecer nenhum problema. Então, até nisso a gente tem que pensar na hora de escolher um tema, porque o LabVirt vai ajudar na compreensão do aluno naquele conceito, se eu tenho um conceito que eu mesma sozinha posso conseguir misturando sal com a água, então beleza. Não preciso por isso numa simulação. Faltou aí a finalidade, e o objetivo? Qual o objetivo dele com essa aula? Alguém sabe me dizer?

M4. O objetivo do experimento e não da aula?

P. Do módulo inteiro não tem aquele objetivo final, que um deles é que eles consigam fazer a encomenda, com essa aplicação que eles façam pesquisa, que eles aumentem o conhecimento na área de combustão. Olha quantas coisas ele deve ter em mente aplicando esse módulo, ele precisa deixar claro prá gente o que ele quer, se não como é que ele vai avaliar? Como é que ele vai avaliar se deu certo se ele nem sabia o que ele queria...

M2. Na realidade eu acho que ele sabia o que ele queria, mas não escreveu.

P. A gente precisa deixar claro até para você saber depois, você mesmo avaliar a sua prática, a sua ação. 
M2. Eu estou entendendo a sua colocação, mas na realidade a gente sabe, o fato é que eu, por exemplo sou uma pessoa que gosto muito mais de falar do que de escrever, então eu tenho muita dificuldade em escrever, provavelmente porque eu me policio muito mais, porque eu vou ver uma série de outras coisas, enfim, e eu acho que a dificuldade é da escrita mesmo. Com certeza na hora ele pensou em alguma coisa sim, só que ele omitiu, ficou só na parte dele. Lógico que aquele que tá lendo não tem noção, não tem como tirar só um pedacinho da cabeça dele.

P. Bom e aí ele passa prá aula 1, aula 2, aula 3, enfim, ele coloca que ele não deixou aquela coisa separadinha por colunas, mas ao longo do percurso, ao longo do registro dele ele põe "levantamento das idéias dos alunos sobre o que é queimar o material", como é que ele vai fazer isso? Ele vai marcar as resposta na lousa então ele vai fazer a pergunta e as pessoas vão... então a metodologia dele já tá incluída aqui no meio de uma certa forma. Em nem todas as aulas eu percebi, mas ele tenta colocar aí como ele vai fazer todas as atividades dele. Definir com os alunos o termo combustão ao invés de queima, problematização inicial com as questões, o que é necessário para que haja uma combustão, marcar as resposta na lousa de novo. Aí vai fazer um experimento demonstrativo, queima da palha de aço, então no caso aqui ele colocou referência prá gente, isso prá vocês verem como é importante, eu como orientadora vou lá no livro e vou buscar essa experiência. Como é esse experimento, e vai iniciar a leitura do texto já dando as explicações do jeito que tá no livro do GEPEQ. Então eu sei ir lá e buscar e ver qual texto ele vai utilizar, se ele vai buscar um texto de revista, de jornal com o tema, seria interessante que vocês colocassem uma xerox prá gente ver que texto é esse, e ver o que mais pode sair daquele texto, o que mais pode explorar daquele texto e tudo mais, ou põe a referência prá gente buscar. Importante também seria colocar prá cada aula, a gente tem um objetivo maior que é chegar em uma simulação, que ele aprenda melhor a combustão que ele faça pesquisa, que ele interaja, tem várias atitudes propostas e a gente por aula às vezes tem uns objetivos específicos, "Nessa aula eu quero formar a idéia de combustão" tem um objetivo específico meu nessa aula.

M4. Sabe uma coisa que eu estou sentindo falta aqui Marcela? É saber quanto tempo é cada aula dessas.

P. Isso, tempo de aula é legal. 
M2. É isso que eu ia te perguntar, esse tempo é tempo de aula, ou é tempo em cada momento aqui. Porque olha "Levantamento das idéias" ele vai gastar meia hora, uma hora, quinze minutos.

P. Isso mesmo, tempo de cada atividade e tempo de aula. Eu coloquei também aqui, por exemplo, eu não sei se aqui vai ser dupla, se vai ser dobradinha, se vai ser uma aula só, porque às vezes é muita atividade que eu coloco prá uma aula só...

M1. Nós acabamos de comentar isso...

P. Então vai dar muita coisa em uma aula só, de repente é uma dobradinha e eu não sei. E aí o interessante é a gente falar "Vou demorar cinco minutos prá isso" e deu cinco minutos, legal então vamos partir prá outra, e a pior coisa é a gente começar um assunto e não dar o fim naquela aula, a gente só vai ver o aluno às vezes depois de quinze dias, né porque aí semana que vem tem um campeonato naquele dia, teve uma palestra não sei de quem, é emenda de feriado, e aí os alunos nem viram onde eles pararam, e aquele trabalho não foi concluído e você tem que retomar e já se perdeu mais tempo por causa disso.

M4. Aí a questão da divisão do tempo das aulas, aquela coisa que a gente discutiu semestre passado, que tá exigindo muito disso na prática dele, principalmente quando você separar aula prá reunião de grupo, que vai ser uma proposta, pegar essa dobradinha só para reunião de grupo, se eu falar que o grupo tem trinta minutos prá se reunir, dez minutos prá me apresentar o relatório e cinco minutos para avaliação, esquece, não acontece. É linguagem mental. Todo mundo correndo, fazendo as coisas de qualquer jeito, falando que não vai dar tempo, o pessoal da noite também...

M1. Eu acho que isso é legal, mesmo quem não começou ainda o trabalho diretamente do LabVirt, vai ainda formular, em algumas atividades que a gente for fazendo já ir começando "Olha vocês tem que responder esse questionário até nove e meia, nove e meia todo mundo tem que entregar". E aí você vai ver se deu esses trinta minutos ou não deu, e aí você vai percebendo se pode ou não pode, que é aquela coisa do reavaliar. Prá uma classe em meia hora ele pode responder, e a outra classe precisa de trinta e cinco minutos ou de vinte e cinco ou de vinte porque acabou antes. Mas eu acho que a gente pode ir treinando... eu falo isso porque eu nas minhas avaliações eu treino "Vocês tem cinco minutos prá preencher isso, cinco minutos prá isso e o resto prá isso" às vezes acontece de "Professora tô na quinta questão e tocou o sinal", "não tem 
problema, tava dentro dos cinco minutos, na próxima aula a gente retoma da quinta questão ou da sexta". Eu acho que é legal prá gente prever o outro trabalho depois, o LabVirt.

P. Já ir acostumando com o sistema de trabalho.

M4. Se você conhecer também esse trabalho que vai cair, porque tem aluno que se dá muito bem com o prazo, ele tem essa habilidade ou essa competência, ele já tem essa disciplina. Mas tem aluno que você fala que tem meia hora... por exemplo a Marcela deu prá gente quinze minutinhos prá responder quatro questionário, a Marcela é chefe e deu a meia hora inicial, a Marcela deu mais quinze minutinhos antes da fala dela, a gente ficou papeando em cinco minutos dava prá ter respondido. Foi mais ou menos isso, então a gente percebe que acontece isso com o nosso aluno também. Por isso que é bom, como ela falou, a gente tá medindo qual aluno me dá uma boa resposta com prazo e esse aluno acaba sendo controlador de tempo nas reuniões e assim por diante.

P. A gente tem um mês prá entregar o trabalho, e a gente faz que dia? Sexta à noite prá entregar no dia seguinte.

M6. É como planejamento, a gente sabe que tem que entregar e no dia anterior você vai fazer.

P. Questões de entendimento de texto, então ele vai falar "Passar na lousa e deixá-los fazendo", em quanto tempo? Que questões são essas? Gente lembrando, aproveitando o gancho da aula de ontem, questões abertas, questões fechadas, questões acadêmicas ligadas ao conceito, questões abertas ligadas ao contexto que você quer. Todas as questões que a gente puder colocar dentro de um questionário é importante, não fazer sempre só questões de interpretação de texto, pergunta e resposta que tá lá... isso não leva muito o aluno a pensar. Então é importante um pergunta fechada? É importante prá ver que conceito envolvido ele sabe. Perguntas abertas também são, relacionadas com o dia-a-dia deles. Correção das questões, revezar o laboratório da próxima aula, lembrando que em nenhuma aula ele prevê a ata, o que o aluno tem que fazer.

M4. Mas esses instrumentos são específicos das reuniões dos grupos do LabVirt. 
M1. Eu não entendi direito se essa "interpretação de texto" é em grupo ou individual.

P. Todas as metodologias da aula, se eu já pensei antes... chega um aluno e fala "Professora pode ser em dupla ou pode ser em quatro", se você já pensou você fala que não que vai ser individual porque eu preciso... às vezes pode ser em grupo porque eu pensei assim...

M6. Questões abertas são interessantes para esclarecer todo o grupo né, e discutir. E quando a questão é fechada é aquela coisa mais simples que a pessoa faz sozinha, então você tem que prever e já imaginar como vai agir.

P.Não ser induzido pelos alunos. Experimento de formação de gás carbônico na água de barita, questões sobre o experimento dado aos alunos junto com o roteiro do experimento prá ser respondido no final de cada aula. Então eu coloquei: Qual é o roteiro? Quais são as questões do experimento? Na aula 4 ele coloca um monte de coisas. E eu coloquei aqui se dá tempo de fazer tudo isso em uma aula só. Vai problematizar, vai levantar a idéia do aluno, vai dividir a turma em grupos, uma turma vai levar para sala de informática e a outra turma vai ficar pesquisando.

Todos - Protestos de ser uma proposta incabível.

M4. Então ele já selecionou os livros e pesquisou o assunto na internet.

P.Isso também é coisa que a gente tem que pensar quando selecionar material prá eles, porque eles não têm acesso mesmo. Pedi prá eles um recorte de jornal e ele não tem mesmo como ter jornal. Então a gente tem essa dificuldade também no Estado de não ter onde eles acharem recurso prá pesquisa, dependendo da escola é muito difícil mesmo.

M3. Dependendo da clientela eles não tem nem dinheiro...

P. Atividade da aula 7, aula 6 e 7 eu não coloquei nada, atividade de pesquisa bibliográfica, metade da turma a outra metade vai estar no laboratório, quanto tempo prá isso? Eu acho que às vezes é melhor uma aula na outra troca do que parar no meio enfim. Ele vai apresentar o LabVirt só na aula 7. 
M4. Devia ter feito a apresentação na proposta de produção.

P. Apresentação da proposta de encomenda do LabVirt. Muitas atividades na aula também. Então a gente precisa ver onde vai apresentar o LabVirt, e eu acho que é uma coisa que vocês falam até no começo do ano, no planejamento de vocês. Sabe aquela aula de apresentação do primeiro dia que a gente só fala e fala, já toca brasa no LabVirt aí também.

M4. Na minha sala no primeiro dia eles já estavam floreando já, sabe aquele primeiro módulo, então esse primeiro módulo é complicado mesmo.

P. Aqui ele coloca apresentação das encomendas dos grupos e discussão dos pontos positivos e negativos de cada encomenda. Eu acho que é legal essa discussão em grupo com todos dando idéias, grupos falando um para o outro, e aí todos os grupos colocam a sua posição. Aqui ele fala que vai fazer a reformulação na aula seguinte em sala de aula. Eu acho que é uma coisa que ele pode estar fazendo em casa, aqui todos já estão com a encomenda pronta, os grupos sabem as encomendas deles, foram feitas sugestões, ele não pode estar fazendo isso em casa, em vez de perder uma aula para a reformulação da encomenda? Então ele pode estar pensando em passar atividade para casa, deles pensarem na reformulação das encomendas.

M4. Ele precisa de tempo prá analisar, recolher esse material observar e devolver por aluno.

P. Então aqui já foi a apresentação, aí ele coloca assim que depois da discussão e dos pontos positivos e tal... eles vão ter uma aula para reformular. Então eu acho que dá para eles tentarem fazer isso como atividade de casa sem perder uma aula.

M5. Eu acho que ele deve estar presente prá estar monitorando dependendo do que...

M4. Tem que fazer observações ali como eu falei...

P. Bom aqui uma sugestão de evitar atividades repetitivas. Quando vocês forem fazer o planejamento, para que eles não se cansem, diversificar as atividades que você vão propor e utilizar as outras ferramentas do LabVirt, que eu não vi aqui no 
planejamento. Então nós vamos consultar o Fórum neste momento... vamos colocar "consulte o químico" nesse outro momento... não esquecer dessas duas coisas.

M3. Tem internet nessa escola?

M5. Estamos trabalhando com um monte de coisas, não apoiada, mas dá uma idéia forte para trabalhar em sala de aula.

P. Então aqui no final vocês vão colocar também a parte da bibliografia, prá gente ter uma noção do que vocês estão utilizando, que livro de apoio que vocês utilizam, essas coisas assim prá gente ter uma idéia. Tanto aqui como no planejamento geral, vem um planejamento geral às vezes grande, quando você vai olhar não tem nenhum livro didático que o professor vai utilizar. Recursos: livro didático. Mas não fala qual.

M4. Deixa eu colocar uma questão. Lá na escola fizeram a gente mudar um pouquinho a questão do planejamento geral da disciplina, porque junto com a diretoria a gente preparou uma reunião e o que a gente pediu para os professores? A gente montou uma tabelinha no computador, a diretora da minha escola, e o que a gente pediu para os professores no começo do ano foi uma relação de conteúdo programático por disciplina, por série. E prá gente desmistificar essa questão do professor, porque isso aqui que a gente faz na semana de planejamento, essa questão que a gente levantou, é o trabalho burocrático que vocês, o diretor também e o professor odeiam fazer no começo do ano. Já é prever porque aqui não sei quais salas, eu já sabia que estavam com os terceiros anos, mas, muitos professores OFA não sabiam, ou estão chegando da diretoria e caem de gaiato em cima disso daqui. Então foi uma forma de a gente padronizar os conteúdos dos três anos, agora que a gente tá tendo contato com os alunos, quando os módulos já estão acabando os professores começam bimestralmente a elaborar essa documentação, mas essa documentação não vem para nossa mão, ele não tem a obrigação formal de entregar, ele vai precisar por lá projeto diversificado, um projeto diferente, aí vem prá nossa mão o plano de aula do bimestre. Mas caso contrário vai ter o seu modo de planejar. Diminui a papelada na minha mão, porque eu não vou ter que administrar muito, porque o modo como a gente pois, como a Marcela falou eu só vou ter que encadernar e mandar para a diretoria de ensino, já tá no formato porque a gente falou pro professor levar num formato bom prá encadernar. O professor vai ter a maior liberdade depois prá fazer sua aula, planejando a aula especificamente com aquela turma que ele tá trabalhando, isso prá gente, eu e a P2 que vamos trabalhar com o LabVirt, é uma mão na roda. 
M3. Prá cada turma vai planejar?

M4. Primeiro colegial, primeiro, segundo e terceiro bimestre, aí depois vem o segundo, os terceiros e assim vai, e por exemplo o LabVirt prá mim e prá Solange tá mais tranqüilo. Porque agora ainda vou ter que apresentar tudo no começo do ano, como a P2 fez no ano passado, planejando as aulas da turma passada, inicial com uma papelada, a gente apresentou o conteúdo programático, a gente assinalou nesse conteúdo aonde tá o LabVirt, então agora no primeiro bimestre vou trabalhar o LabVirt e a teoria dos gases, depois vem a introdução da Química orgânica, né que o que a gente tá planejando, aí eu vou ter uma brecha de tempo aí, agora vou ter dez dias de espaço modular, dez dias que eu vou sentar com o conteúdo do plano de aula com o Alexandre ou... que eu vou estudar prá ficar tranqüilo. Então a gente se desvencilhou um pouco. Eu tava ouvindo o que vocês estavam falando e resolvi partir prá defesa dos PCPs, porque dá para fazer, porque se a gente orienta professor, se a gente desmistifica isso, deixa de ser um trabalho burocrático chato deixa de ser uma obrigação profissional. Eu falei para eles, esse ano eu só quero a relação dos conteúdos programáticos, tanto que a reunião da gente foi uma delícia, a gente discutiu projeto, a gente pegou... a gente fez um dia e meio, a gente trabalhou seis horas cada dia, então foi um dia e meio, oito horas de trabalho só discutindo atividade com a escola, só discutindo meios ... recursos que a gente ia precisar, no último dia em meia hora os professores [...] e nas outras duas horas que sobraram a minha diretora usou com recados administrativos e tal, que aí eu deixei com ela duas horinhas finais. Mas a quinta e a sexta foi de trabalho intenso, encaixando dinâmica, encaixando socialização... a gente entrou com um projeto de estar vendo o protocolo de Kyoto, sentou eu a professora de geografia e a professora de Química, prá fazer todo mundo. Agora esse bimestre a gente tá falando isso, eu tô com gases com meus alunos do terceiro ano no primeiro bimestre, então com essas duas prá dar o LabVirt eu tô trabalhando a diminuição na emissão de poluentes na atmosfera, junto com a professora de geografia, que tá analisando as questões ambientais na aula de geografia, e a professora de história que tá analisando os países que tem problema prá assinar o protocolo. Então essa é uma coisa bem interessante, planejamento então virou isso, virou planejamento de ação.

M6. Você está defendendo, mas você é uma exceção.

P. Bom valeu, importante também seria se vocês dessem uma olhadinha na apostila. 
194

ANEXO 4. QUESTIONÁRIOS PRÉ PROJETO

LabVirt

QUESTIONÁRIO PRÉVIO Á ATIVIDADE DE PLANEJAMENTOS

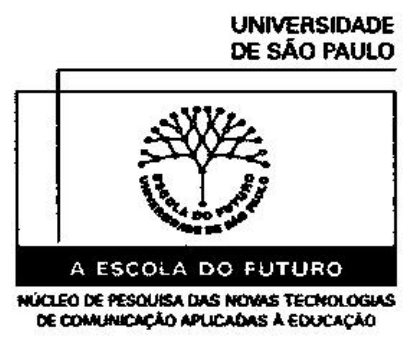

Encontro Mensal LabVirt Química 18/05/2005

1. Para você, o que significa planejamento de ensino e qual sua finalidade?

Planifamento de ensino e'Tum roturo erientódorl que [serve para direcionarmos a aprendigagem]

2. Qual a importância do planejamento para a sua prática?

Catrave's do planejamento podemos diagnosticar, araliar, replanejar $\theta$ trabolhe de ensino aprendizogem $]^{76}$

3. Como é realizado o planejamento da sua escola?O que você sugeriria para melhora-lo, se fosse necessário?

Hoplanijamento éfito com djetivos gerais da uscola e oljetivos específicos da disciplina. ${ }^{77}$ hão vejo necessidode de mudameas visto que ele i'flexurel.

4. Você replaneja? Porquê? Em qual momento?

Sim, [poque nem sernpre covre um acompanhamento por parte das turmas no que refore a sequencia do planejamento]e a frecesisedode de replanejar pode ocover no final dos limestres] $]^{79}$

5. Quais itens devem ser pensados para elaborar o planejamento?

[Realidade da escola, da comunidade $]^{80}$ e do

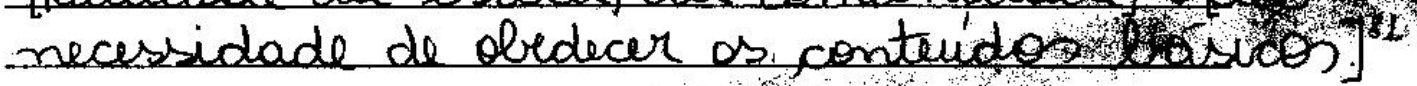


195

6. Como vocé seleciona o conteúdo de química?

IDs eiveos norteaderes sas a proposta da CENP e os PCNS] $]^{32}$

7. A cada ano o conteúdo muda ou é o mesmo? Justifique.

$\left[10 \text { conterido } e^{\prime} 0 \text { mesmo }\right]^{83} 0$ que [muda $e^{\prime}$ a abordagem. $]^{84}$

8. A avaliaçăo diagnóstica é feita?

Leim [para verificar se reabmente. esta ocorrendo a compreensas e aplica cad da aprendizagem $]^{35}$

9. Quais sāo suas referências para o planejamento?

[Propesta CENP, PCNS, periódicios, livon didáticion $]^{86}$

10. Você planeja só o conteúdo geral ou planeja cada aula também?

Registros apenas para o conteúdo geral. Enas tirha a hálito de registron por aula $]^{87}$ mas agora estou comecando a fazê-los

Nome (opcional):

P1 


\section{Labivirt}

\section{QUESTIONÁRIO PRÉVIO Á ATIVIDADE DE PLANEJAMENTOS}

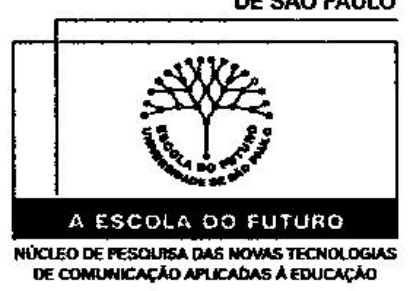

\section{Encontro Mensal LabVirt Química 18/05/2005}

1. Para voce, o que significa planejamento de ensino e qual sua finalidade? Ilignifica enganizan is contuidis

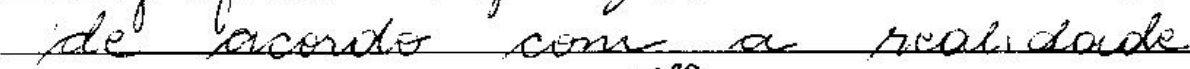

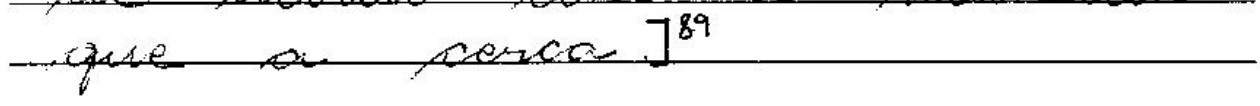

2. Qual a importância do planejamento para a sua prática?

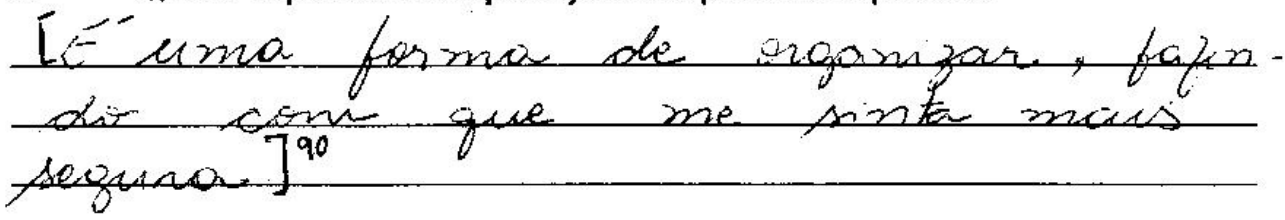

3. Como é realizado o planejamento da sua escola?O que você sugerina para melhora-lo, se fosse necessánio?

EE reahizach em grupo com bax nos

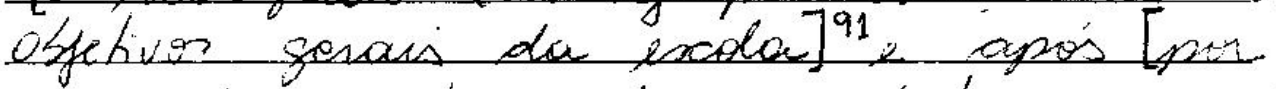

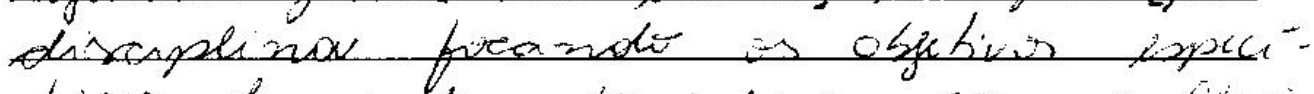
fins de cada discrpinza cinu a fixi. 4. Você replaneia? Porquê? Em qual momento?

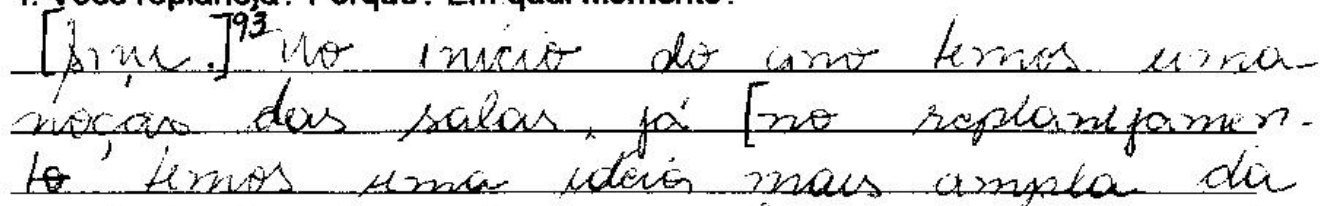

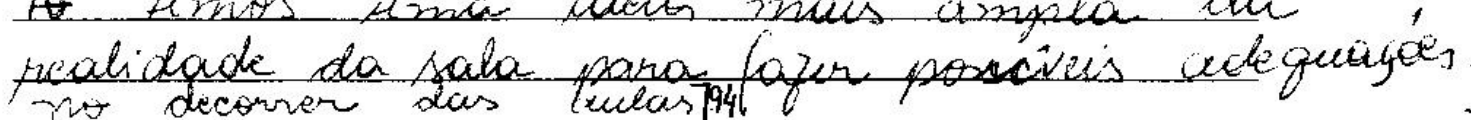
5. Quais itens devem ser pensados para elaborar o planejamento? I G nowidode da ecola, da

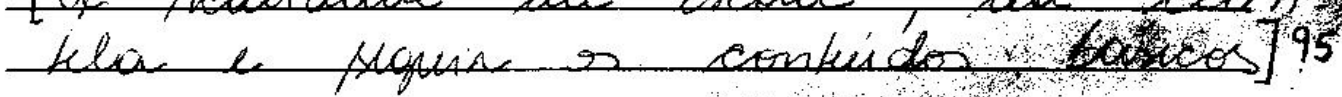


197

6. Como você seleciona o conteúdo de química?

[Com base mos $\mathrm{PCN}_{5} 2$ a sealidade der comu nudade $]^{96}$

7. A cada ano o conteúdo muda ou é o mesmo? Justifique.

[i) contuivio nái muda apinas sá́ futas as modifificarínes mevensoinas

8. A avaliaçăo diagnóstica é feita?

$[\text { Sim logo no incéio das aulas }]^{98}$

9. Quais são suas referências para o planejamento?

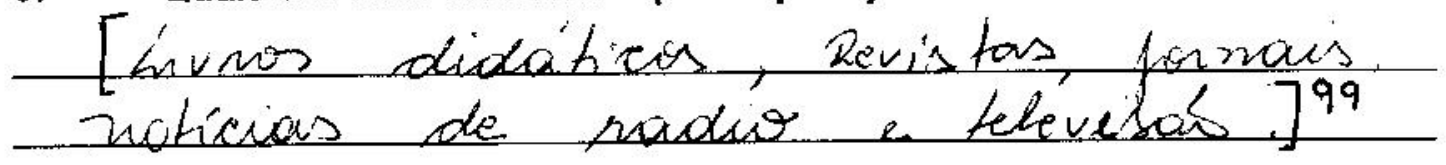

10. Vocé planeja só o conteúdo geral ou planeja cada aula também?
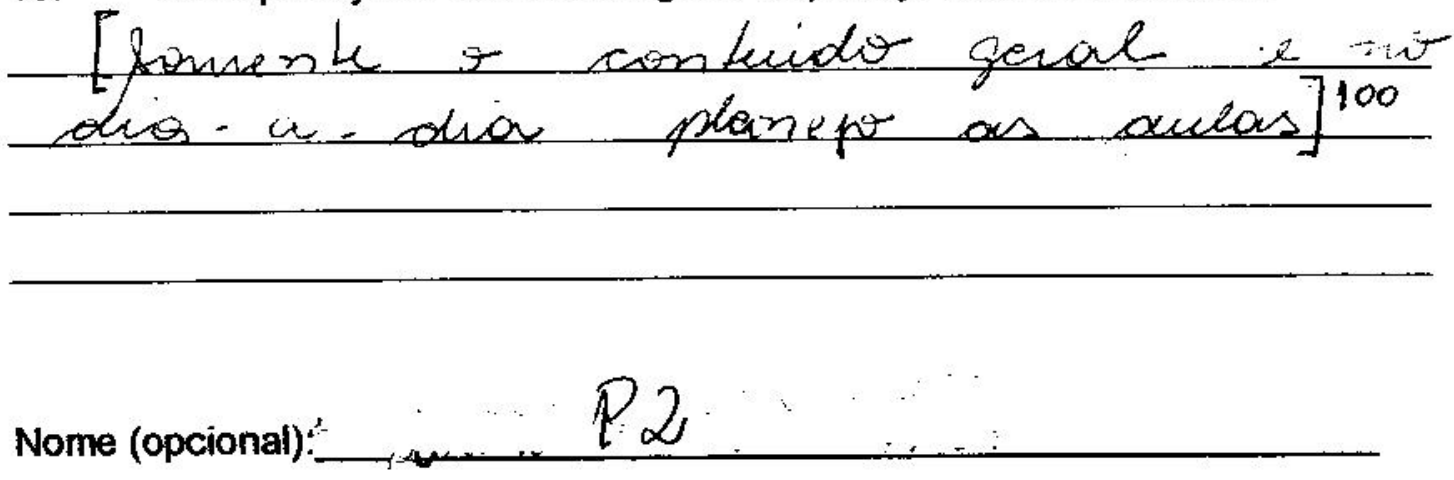
198

Virt

QUESTIONÁRIO PRÉVIO Á ATIVIDADE DE PLANEJAMENTOS
UNIVERSIDADE

DE SAO PAULO

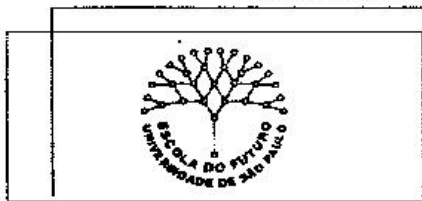

A ESCOLA DO FUTURO

OECLO DE PESOUISA DAS NOVAS TECNOLOGIA

Encontro Mensal LabVirt Química 25/02/2005

1. Para vocé, o que significa planejamento de ensino e qual sua finalidade?

1 Dlanejámento de Ensino [é um rorteador das acoer en sale de ala $]^{54}$

2. Qual a importância do planejamento para a sua prática?

1 Planejamento Epadroniza a prática, mesmo com estratégias diferenciadas (p/ $\neq 1$ salas)] 55 Egarantimos um mañor oprovertankento de Sbitivos idealizados. $]^{56}$

3. Como é realizado o planejamento da sua escola?0 que você sugeriria para melhora-lo, se fosse necessário?

As reunioés de plan este ano, [forom valtado, pt o Conten do Programatico do discolinar,afi-. de padromiza-bos] $]^{57}$ Num outro momento, [bareado $n=$ C.P. elaboramos proposte de a fividades. 58

4. Você replaneją? Porquê? Em qual momento?

[Som]. flara melhor atendes as hecesuidader especificas de uma turma ou "momanto".] 60

5. Quais itens devem ser pensados para elaborar o planejanento?

[1-Conterido Programático $]^{61}$

[2- Realidade da elientela $]^{6.2}$

[3-Esprafiridade de cada furma $]^{63}$ 
199

6. Como você seleciona o conteúdo de quimiça?

[Ovientacks dos exame eficiais] [ENEN] $]^{65}$ [Vertibulare ] 6 ex.

7. A cada ano o conteúdo muda ou é o mesmo? Justifique.

[E o mesmo]. [una vez gu proaranos manter un padras de traballo (conterido) andependente da vercessas de profenore $]^{68}$

8. A avaliação diagnóstica é feita?

Sim, Epara redefinir an entratégics e mefodo logios en uma dos conterido $]^{69}$

9. Quais são suas referèncias para o planejamento?

p/ o conterids prograncítico [orientager de examm.] [livios didáticos] $]^{71}$, t.

7/ metodologia e estratégia : [PON'S], [orientaserer da SE]

10. Você planeja só o conteúdo geral ou planeja cada aula também?

O conterids geral, comp prinapio Norteador.

[Cada modulo segue descrito separadale imais especificate e personalizado à clasgl] $]^{74}$

Nome (opcional): 
200

Labirir

QUESTIONÁRIO PRÉVIO Á ATIVIDADE DE PLANEJAMENTOS
UNIVERSIDADE

DE SÃO PAULO

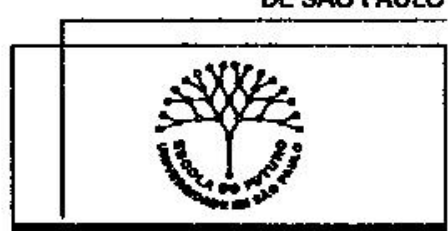

A ESCOLA DO FUTURO DE COHEHESCUMSA DAS MONAS TECNDLOGLAS

Encontro Mensal LabVirt Química 18/05/2005

1. Para você, o que significa planejamento de ensino e qual sua finalidade?

Eplanejomento [quxila no contevido a ser dedo olurante o ano $7^{58}$

2. Qual a importåncia do planejamento para a sua prática?

[Auxilia no eurso.j59

3. Como é realizado o planejamento da sua escola?O que você sugeriria para melhora-lo, se fosse necessário?

comeso do ano $]^{60}$ que [falla - ter mai contato com outwos colegas de química para trocas de ideias] $]^{61}$

4. Você replaneja? Porquê? Em qual momento?

[Sim]. [Deromte o curso] $]^{63}$ wa vendo as [dificuldades dor slunas \& como eles, estoo se comportando com 0 contevido dodo] $]^{64}$

5. Quais itens devem ser pensados para elaborar o planejamento?

toder. 
201

6. Como você seleciona o conteúdo de química?

Ellue tenhia uma sepuénia mais lófica $]^{65}$

7. A cada ano o conteúdo muda ou é o mesmo? Justifique.

Madifico conforme a nola e suas difieulataden $]^{66}$ sempre que posivel comento um asuento do div a dia.

8. A avaliaçāo diagnóstica é feita? $[\text { Sim] }]^{67}$ hanto é que [quando vgi. modifico meu plangomento] 68
neeenidade

9. Quais são suas referências para o planejamento? do assunto u "pago" um livno e depedendo do assunto atro livioj70

10. Vocé planeja só o conteúdo geral ou planeja cada aula também?

[Suands un dar um asxinto que neo vejo algum tempo en voth a dar uma estudoda no contéido.] ${ }^{71}$

Nome (opcional):

$P 4$ 


\section{QUESTIONÁRIO PRÉVIO Á ATIVIDADE DE PLANEJAMENTOS}

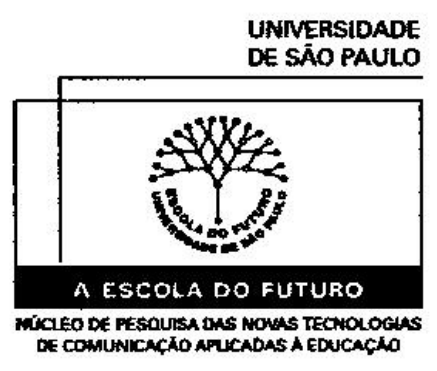

\section{Encontro Mensal LabVirt Química 18/05/2005}

1. Para você, o que significa planejamento de ensino e qual sua finalidade? Sigmifica [oreparar o que será ensinado durante 0 ano] 57 [as diretrizes, os caminhos que deveraís ser trabalhados] ${ }^{58}$ $E$ de extrema importancio es sua finalidade e Tdirecionar - trabalho dos nofusores] tauxaliando sen trabalho no deconer 2. Qual a importância do planejamento para a sua prática?

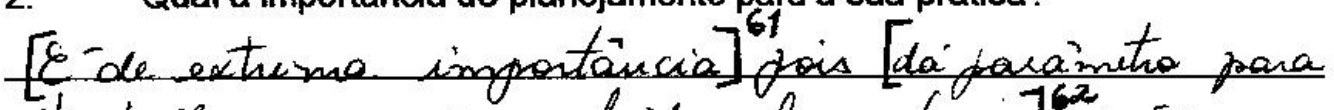
e trobalho a see desencolvido jelo profino $]^{62}$ ja que esse Fhanefamento de pende da escola dos alunos e de

3. Como é realizado o planejamento da sua escola?O que você sugeriria para melhora-lo, se fosse necessário?

[E'sealizodo no inicio do ano $]^{64}$ onde es professores se recínem pos área e [definimos temas gerodous, alem dos poofetos que peras desencolvidos en cada

4. Você replaneja? Porquê? Em qual momento?

Sim, wenmalmente seplanefamos no 30 bimeste, porque [e'necestário reavaliar e que ja'fordado] therificar a necessidade de retomar o assunto ov continuar o planfolo, ou atémesmo vardar totolmente e pue for planefada]

5. Quais itens devem ser pensados para elaborar o plangiamento?

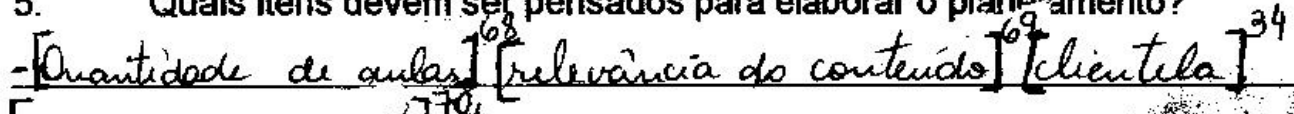
[recusos da escola $]_{\text {etc. }}^{70}$ 
203

6. Como você seleciona o conteúdo de química?

We acondo com Qu contéudos selucionados en $[\text { vestibulares] }]^{48},[E N \in M]^{49}$ e $[\text { concursos }]^{50}$

7. A cada ano o conteúdo muda ou é o mesmo? Justifique.

[Lepende]. Se o planejamento do ano anterior náo foi cumprido por falta de tempo, o planijamento érefito pana poder encaixar os conterído que realmente säo necessário $]^{52}$.

8. A avaliaçāo diagnóstica é feita?

$[\sin ]^{53}$, Emax quase sempre nä̀ applicada].

9. Quais sāo suas referências para o planejamento?

[Discusráa com oxtros coleges] $]^{55}$

10. Você planeja só o conteúdo geral ou planeja cada aula também? ambas

Nome (opcional): $\quad P 6$

- [a clientelo a quem esta sindo dirigido o cuso $]^{45}$

- [or vecurson niateniair e físicos da $V E]^{46}$

- [o tempo disponéch dentro e fora da excola $]^{47}$ 


\section{Virt \\ QUESTIONÁRIO PRÉVIO Á ATIVIDADE DE \\ PLANEJAMENTOS}

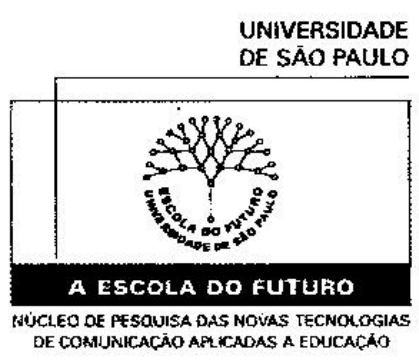

\section{Encontro Mensal LabVirt Química 25/02/2005}

1. Para você, o que significa planejamento de ensino e qual sua finalidade? Pensar pre as atitudes ideias a peren tomadas. durante o aur letwio] $]^{63}[$ som relacps an recurvos humanoo e. frócios que a U.E. apresenta a como utilizá-los].

2. Qual a importância do planejamento para a sua prática?

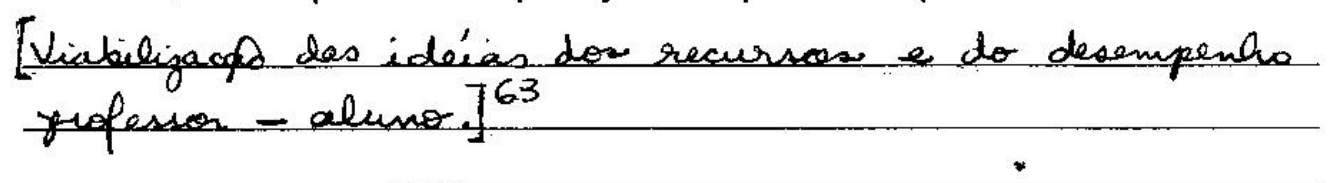

3. Como é realizado o planejamento da sua escola?o que você sugeriria para melhora-lo, se fosse necessário?

Formal $\rightarrow$ porcódo yrogramado pela pecretaria de aducacdo/diratoria de ensiñ; quando acontere! $]^{64}$ Wuformal $\rightarrow$ "Bate - entra pofessores durante o ano letwio e havamente nos HTPC's. $]^{65}$

4. Você replaneja? Porquê? Em qual momento?

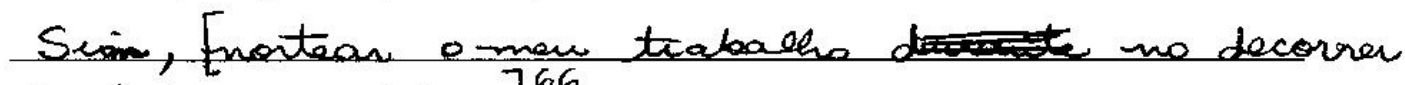
de todo ano latino. $]^{66}$

5. Quais itens devem ser pensados para elaborar o planejameation

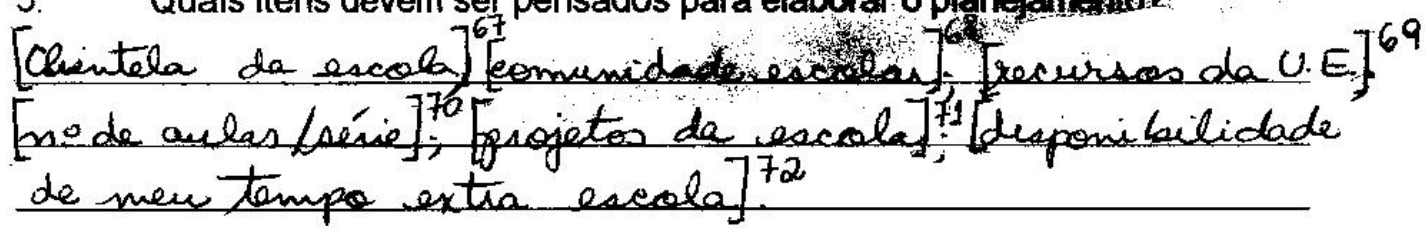


6. Como vocé seleciona o conteúdo de química?

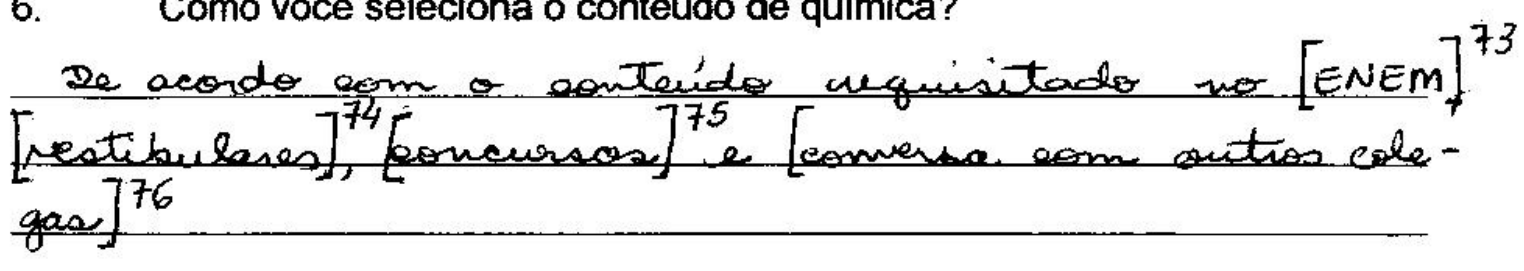

7. A cada ano o conteúdo muda ou é o mesmo? Justifique.

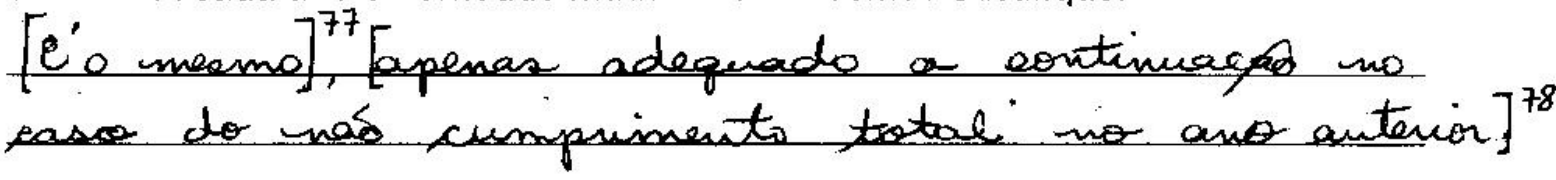

8. A avaliação diagnóstica é feita?

[Sim, mas quase pempre nod aplicada totalmente. 79

9. Quais são suas referências para o planejamento?

Fuscirss eom outros colegan] [ENEM] [restibulares] $]^{82}$ [eomberminento dos alumes] ${ }^{83}[$ lives] 84 atc

10. Você planeja só o conteúdo geral ou planeja cada aula também? Contendo e aulas.

Nome (opcional): __. P 


\section{ANEXO 5. TRANSCRIČÃO DAS ENTREVISTAS}

\section{ENTREVISTA COM P1 (08 DE AGOSTO DE 2005)}

P. Em que momento é feito o planejamento na sua escola?

P1. Quando eu entrei aqui (neste ano) foi feito [no início do ano] ${ }^{1}$, o planejamento anual.

P. Quantos dias são dedicados ao planejamento?

P1. Foram dedicados no [começo do ano três dias e agora no início do segundo semestre, dois dias, que foi um replanejamento. $]^{2}$

P. Você achou suficientes esses três dias prá planejar as suas aulas por ano?

P1. Foi. Foram suficientes sim. É porque quando a gente [fala suficiente em termos de conteúdo] ${ }^{3}$, foi. Agora, em termos de você ter [reais projetos, aí não foi] ${ }^{4}$. Porque sempre cai naquela [mesmice, né. Você selecionar os conteúdos e falar sobre alguns projetos] $]^{5}$. Mas assim, [detalhar] ${ }^{6}$, precisar esses projetos aí já não teve tempo prá isso. Porque você tem que [estar selecionando material, vendo como esse material vai chegar até você, não só ficar no papel.] $]^{7}$ Então isso daí eu acho que é a falha. É aquele [tempo prá estar planejando a ação.] ${ }^{8}$

P. E esse planejamento foi discutido com outros professores da disciplina ou da área?

P1. [Foram discutidos com a disciplina sim. $]^{9}$

P. Com a disciplina?

P1. É com a disciplina. Mas assim, apesar da disciplina ser em comum, [a realidade é um pouco diferente por período. $]^{10}$

P. E mesmo assim se padronizou um planejamento prá todo mundo?

P1. [Tentou-se comum, padronizar.] ${ }^{11}$

P. E você acha que essa discussão com outros professores é necessária?

P1. De outras disciplinas?

P. Não da mesma disciplina. Vocês tiveram com a mesma disciplina. Você acha que é necessária essa discussão?

$\mathrm{P} 1$. É [necessária prá ter um ponto em comum na escola] ${ }^{12}$, porque a própria diretora colocou isso no começo do ano, que teve esse problema nos anos anteriores, de se [fazer um planejamento com conteúdo em comum, padronizado] ${ }^{13}$ e quando chegar numa determinada época do ano que aluno precisa remanejar de um horário pro outro, [teve aluno que veio do noturno prá manhã ou vice-versa e o conteúdo com o mesmo professor era totalmente diferente.] ${ }^{14}$ Não era nem a seqüência, que às vezes não tem 
tempo. O tempo não é possível. Mas é o conteúdo mesmo. Totalmente diferente. Então ela pegou no pé em relação a isso daí que tem o quanto mais padronizado possível.

P. Você consulta esse planejamento anual ao longo do ano? Você o tem, você consulta ele?

$\mathrm{P} 1$. [Tenho. $^{15}$ Já tenho em mente já o que foi planejado em termos de conteúdo, atividades e [sempre estou acompanhando.] ${ }^{16}$

P. Aqui você coloca que o planejamento é flexível. Como assim flexível? O que você quis dizer com isso?

P1. Nesse momento aí, eu quis dizer o seguinte: que você aborda tópicos por bimestre, né. $E$ dependendo... $E$ você vai prá realidade da sala de aula, principalmente no começo do ano. Então você tem um diagnóstico. Você planeja, mas você chega na sala de aula e você [faz um diagnóstico.] ${ }^{17}$ Então [de acordo com aquele diagnóstico você pode estar alterando o seu planejamento. $]^{18}$ Visto que foi meu primeiro ano aqui nesta escola, então ocorreu isso com as turmas da $2^{\mathrm{a}}$ série. Do $1^{\circ}$ ano, eles chegaram e estão acompanhando normal o planejamento. Agora as $2^{a}$ séries eles vieram com uma defasagem muito grande da série anterior. Então o que o grupo, eu mais os dois professores da área, planejou no começo do ano, teve que replanejar. Porque não dava prá partir daquele ponto que a gente tinha planejado.

P. Para todas as $2^{\mathrm{a}}$ séries?

P1. Prá todas.

P. Nesse replanejamento você elabora um novo documento? Você registra esse seu replanejamento?

$\mathrm{P} 1$. [Não] ${ }^{19}$. A gente [não teve um encontro prá estar formulando isso no papel.] $]^{20}$ Foi [feito, erroneamente, de boca a boca] ${ }^{21}$, e [essa mudança foi feita via diário, só.] ${ }^{22}$ Agora no segundo semestre é que teve um momento de fazer o replanejamento. Então assim, em termos de documento só foi colocado isso agora, no [começo do segundo semestre que ocorreu esse momento de replanejamento vai ser documentado.] ${ }^{23}$

P. E essas mudanças que ocorrem no replanejamento, ocorrem porquê? O quê que vocês consideram prá fazer algumas mudanças no planejamento de vocês?

$\mathrm{P} 1$. [Os objetivos não atingidos no decorrer do $1^{\circ}$ e $2^{\circ}$ bimestre $]^{24}$, [em termos de conteúdo também.] ${ }^{25} \mathrm{O}$ que a gente considera mais foi assim, [o tempo que não foi hábil] $^{26}$, né. $E$ também o fator rendimento. Às vezes [nem sempre o aluno retorna prá gente naquele tempo que a gente espera. ${ }^{27}$ Então, além da defasagem da série anterior, aí tem o fator tempo também, o acompanhamento do aluno junto com aquilo que a gente propõe.

P. Então as mudanças são, no sentido de assim, prorrogar o prazo prá aplicar aqueles conteúdos? 
P1. [É uma prorrogação. $]^{28}$

P. O planejamento, pelo que eu entendi, ele é único prá todos os $1^{\circ}$, todos os $2^{\circ} \mathrm{e}$ todos os $3^{\circ}$ ?

P1. Isso.

P. Na questão 5, que fala assim, "quais itens devem ser pensados para elaborar o planejamento?" Ai você coloca assim "realidade da escola, da comunidade e da necessidade de obedecer aos conteúdos básicos". O que é que significa esses conteúdos básicos?

P1. [Aqueles oferecidos pelos PCN, pela Proposta Pedagógica da CENP.] $]^{29}$ Porque lá tem os conteúdos a serem abordados. [Dentro daquele conteúdo a gente vai ver qual é a realidade da escola. ${ }^{30}$ A realidade da escola qual seria, [a grade curricular, a realidade da comunidade também, qual que é a situação que a comunidade vive.] $]^{31}$ É até estranho falar isso, mas a [quantidade de alunos que tem, a classe.] ${ }^{32}$ [Se é média, se alta...Alta não vai ter, né. Se é muito baixa ou se é média.] $]^{33}$ Tem tudo isso. Aí tem alguns itens dentro do que é proposto, na proposta pedagógica que [a gente seleciona. Coloca aqueles conteúdos mais significativos.] ${ }^{34}$

P. Além desses itens aqui, o que mais teria que ser pensado para um planejamento? Você vai elaborar o seu planejamento, quais são os itens que não podem faltar?

$P 1$. Hum, os itens que não podem faltar, além daqueles conteúdos básicos, do PCN, da Proposta Pedagógica? É...(pausa) Não podem faltar em termos de que?

P. Em termos da formatação mesmo do planejamento. Prá você entregar um planejamento bem elaborado.

P1. Vai ter que ter o [objetivo, o conteúdo, a metodologia, a avaliação.] ${ }^{35}$ Itens importantes e necessários no planejamento, né?

$P$. Você conhece bem a Proposta da CENP e o PCN?

P1. [A Proposta da CENP sim, o livro verdinho e os PCN do Ensino Médio da disciplina de Química sim.] $]^{36}$

P. Qual é a sua concepção de ensino? Prá você o que é ensinar?

$\mathrm{P} 1$. Ensinar? Olha, [ensinar eu acredito que é transmitir conhecimento.] ${ }^{37}$

P. E você acha que seu planejamento está de acordo com a sua concepção?

P1. No que diz respeito a transmitir conhecimento, sim. E agora, a aprendizagem que aí eu já acho que depende do ensino, mas não é somente dependente dele. Que você tem a transmissão de conhecimentos, [mas só transmitir o conhecimento não é suficiente.] ${ }^{38}$ Você [tem que ter toda uma metodologia.] $]^{39}$ Hoje em dia, mudaram-se as denominações, fala "protagonismo juvenil", né. Então você tem [a troca, na realidade, de conhecimento.] $]^{40}$ Enquanto professor você tem que estar sempre [buscando o seguinte 
objetivo "ensinar a aprender"] ${ }^{41}$, então...Transmissão de conhecimento e ao mesmo tempo também praticando "ensinar a aprender".

P. A avaliação diagnóstica é feita em qual momento?

P1. [No início do ano. $]^{42}$

P. Como que ela é feita? Ela é uma avaliação escrita ou uma avaliação oral?

P1. Particularmente eu faço [uma avaliação oral] ${ }^{43}$ e num outro momento [uma avaliação escrita. $]^{44}$ Porque você já chegar, logo de cara, no começo do ano, falando pro aluno responder questões, é muito difícil. Então você, [através de uma aula dialogada] ${ }^{45}$, você vai sugerindo pro aluno que ele faça aquela investigação sobre o que ele já viu, as dificuldades que ele teve com relação a determinados assuntos dentro da disciplina. Então através daí você vai tendo um diagnóstico sobre o que realmente ele assimilou até então. [O que ele viu e o que ele assimilou. ${ }^{46}$

P. E aí você utiliza esses dados pro seu planejamento, ou não?

P1. [Sim, utilizo sim.] $]^{47}$ [Fazendo aprofundamento de conceitos e também utilizando dentro do conteúdo a ser dado. $]^{48}$

P. No seu planejamento, por exemplo, não consta o conteúdo radioatividade. Como que é feita essa seleção de conteúdos. Por que você seleciona uns e não outros? Quais são os motivos de você excluir um assunto, e colocar aquele?

$\mathrm{P} 1$. Olha vou ser bem sincera. [Tem alguns conteúdos químicos que dependem de um conhecimento anterior mais aprofundando de um determinado assunto. ${ }^{49}$ Não descartando o fato da radioatividade. Bom, [se depende de um assunto prévio anterior que a gente supõe que o aluno não vai ter capacidade de estar acompanhando] ${ }^{50}$, né. Mas eu acho [que fica até mesmo pela acomodação] ${ }^{51}$, vou ser bem sincera, [pela acomodação das escolhas.] $]^{52}$ Porque a [maioria dos outros colégios também não chega a abordar tão profundamente esse assunto dentro da disciplina. ${ }^{53}$ Vai deixando prá outra, né. Porque agora a abordagem é mais física, de estar trabalhando isso. E aí quando chega na disciplina de física, os alunos falam que não tiveram isso na Química e aí vira uma bola de neve. Então, [é errado mesmo a gente pegar e estar selecionando a bel prazer os conteúdos. $]^{54}$ Mas a disciplina de radioatividade a gente discutiu no começo do ano a respeito, tá. Só que teve assim um [fator primordial] ${ }^{55}$ que foi, [aqueles que são mais necessários $]^{56}$, ou seja, [pedidos na maioria das provas de vestibular] ${ }^{57}$, né, e o [fator tempo] ${ }^{58}$, que [não tinha tempo] ${ }^{59}$, nem da [grade curricular que a gente tem] ${ }^{60}$, estar abordando certos conteúdos. E esse daí não deu tempo prá estar incluindo.

P. E aí também, então os outros conteúdos considera-se que eles são mais solicitados pelos exames? 
P1. Isso. É [medo de estar tirando alguns outros] ${ }^{61}$ que já são vistos há muito tempo e colocando esses, né. Medo, acomodação também do professor. E aquilo que diz respeito [ao aluno não vai conseguir atingir os objetivos desse tema.] ${ }^{62}$

P. Como que você se prepara prá cada aula já que não é feito um planejamento por aula, de aula?

P1. Olha nessa escola fica um pouco mais simples até o preparo de aula pelo seguinte fato: [você já tem uma preparação única antes de começar o bimestre.] ${ }^{63}$ Então, por exemplo, eu já sei o que eu vou dar em todos os segundos, no decorrer de 10 dias. Então isso, de uma maneira ou de outra acaba sendo igual prá todas as outras salas. Isso tanto no $1^{\circ}$, quanto no $3^{\circ}$. Então assim, [não está documentado.] ${ }^{64}$ Essa é a minha falha em relação a documento. Não está documentado, mas [eu tenho no diário] ${ }^{65}$ aquele primeiro momento que eu já sei em relação ao [conteúdo, atividades, trabalhos que os alunos irão fazer.] $]^{66}$

$P$. Mas porque você acha que é uma falha não estar documentado?

P1. Porque assim, [tendo essa capacitação agora do Labvirt a gente sabe que é necessário a pessoa documentar tudo.] ${ }^{67}$ Porque na realidade a gente [tem que respeitar a equipe] ${ }^{68}$ também, porque [eu sei o que eu vou dar, mas eu vou estar sendo egoísta eu só saber. $]^{69}$ [E se de repente eu preciso não estar na escola. ${ }^{70}$ Quem é que vai fazer isso? Então tem que ter algo documentado. [Porque eu deixando isso disponível prá escola, caso eu tenha ou faltar ou uma licença, alguém sabe estar acompanhando.] $]^{71}$ Porque está documentado passo a passo o que se é proposto. Porque [você jogar assim, tópico por conteúdo é muito aleatório] ${ }^{72}$, né. Então assim, [o planejamento documentado aula a aula é importante ter na escola porque você não está sozinho nela, você faz parte de uma equipe e a equipe tem que estar sabendo, os coordenadores principalmente, o que é que está sendo proposto por aula também, não só aquele planejamento anual que foi feito num determinado momento. $]^{73}$

P. Você teria condições de fazer esse planejamento aula a aula?

P1. [Teria. É trabalhoso mas eu teria condições.] $]^{74}$

P. Quais seriam os problemas que você acha que impedem de fazer esse planejamento?

P1. [O que impede é tempo. $]^{75}$ Esse é o principal fator, e só. Prá mim só seria tempo. Porque assim, tendo um você vai ter prá todas as outras turmas.

P. Como está sendo ter que planejar as aulas do Labvirt? Então você tem que fazer aula a aula já que hoje você não faz na sua prática, no dia a dia e pro Labvirt você está tendo que apresentar, de uma certa forma uma exigência. Como é que está sendo fazer isso? 
P1. [No começo eu fiquei em pânico.] ${ }^{76}$ Depois com mais orientações eu comecei a me tranqüilizar, porém eu ainda [não tinha assim tanta segurança de como fazer.] ${ }^{77}$ Hoje eu não vou dizer que estou $100 \%$ segura mas a tranqüilidade minha já está chegando a uns $80 \%$. Então assim, eu [tive orientações a respeito de como fazer.] ${ }^{78}$ Outras dificuldades com relação ao tempo prá executar. [Porque você tem que também fazer uma pesquisa.] ${ }^{79} \mathrm{O}$ documento tem que ser detalhado, então faltou esse fator tempo, mas hoje em dia eu já estou tranqüila e eu sei agora começar e terminar. Eu tenho segurança prá isso.

P. E aí você já me disse que você acha que isso é necessário. Seria necessário, hoje prá você dar suas aulas?

P1. [É necessário.] ${ }^{80}$

P. Em que medida esse procedimento auxilia ou atrapalha a sua prática como professora?

P1. Pensando assim objetivamente, ele não iria atrapalhar de maneira alguma, muito pelo contrário, você também vai estar passando essa responsabilidade pro aluno porque o aluno muitas vezes ele vem prá sala de aula sem objetivo, né. Você se pega muitas vezes, dentro de 100 minutos de aula, o aluno só esperando escrever uma lousa. E aí ele copia aquela lousa e você quer passar prá ele qual que é o objetivo daquilo, dar continuidade. E muitas vezes ele também já está acomodado, devido à falta de objetivo que é dado prá ele. Então se você faz um planejamento diário, você vai passar aquilo pro aluno também e você vai cobrar dele. Então se você teve o compromisso de preparar aquilo tendo início, meio e fim, você vai jogar isso pro aluno e aí no final ele vai ter que dar uma resposta prá você. Então olha: - O planejado prá aula de hoje, pro dia de hoje foi esse. E aí, o que é que a gente atingiu no dia de hoje? Você começando a jogar isso pro aluno ele vai começar a ter um pouquinho mais de responsabilidade e compromisso com a aula. Essa é a visão que eu tenho a respeito do planejamento diário.

P. Você hoje elabora o seu planejamento anual por necessidade ou prá cumprir normas burocráticas?

P1. Não, é por necessidade. Porque se não ocorrer o planejamento qual vai ser a ação?

P. Então, se a escola não te pedisse você faria do mesmo jeito?

P1. Faria do mesmo jeito. Porque eu acredito que tudo precisa de organização. Você precisa ter ordem no que você vai dar, no que você espera.

$P$. E isso foi assim desde que você começou a dar aula?

P1. Desde quando eu comecei. Mesmo porque eu fiz magistério, né. Então no magistério você, desde novinha já sabe tudo que tem que fazer. Não é esse planejamento que tem hoje em dia. Mas era aquele planejamento que tinha todos 
aqueles tópicos, né, Introdução, objetivo, conteúdo. Era objetivo, conteúdo, procedimento...Tudo aquilo. Então já era um hábito, já. Desde cedo eu já sabia que dentro da educação tinha que ter essa organização. Você tem que ter fins. Então prá isso...

P. E na sua formação acadêmica de faculdade de Química, a Licenciatura. Foi discutido ou foi ensinado em algum momento como planejar, como fazer um planejamento?

$\mathrm{P} 1$. Olha, sinceramente não. A única coisa que era cobrada era que você sabia que teria que ter organização eram os relatórios. Nos relatórios. Agora na matéria Metodologia e Estrutura do funcionamento de primeiro grau a gente não teve essa preparação. Sabia-se que os conteúdos eram seguidos. Mas eles não deram assim, como você priorizar a escolha dos seus conteúdos. Por quê? A maioria das referências bibliográficas que tem por aí, os livros paradidáticos, vamos ser mais claros, né, eles já tem lá no final aquele objetivo e conteúdo. Aquela seqüência. Então muitas vezes você se sente insegura. Como eu vou escolher? Eu vou mudar aquilo que já existe? Então eu tinha essa insegurança. Tinha muita insegurança. Depois no decorrer, quando eu comecei a estar estudando um pouco melhor, porque eu já tinha uma noção, que aquilo que estava na seqüência dos livros didáticos era um pouco incoerente. Principalmente se você tinha uma grade curricular que não era a quantidade de aulas necessárias para aquela quantidade de assuntos, né. Então começou a dar desespero, enquanto profissional. E aí, depois começando a estudar... Eu fiz parte lá do GEPEQ...Até o próprio Pitombo falou que na época em que ele era professor, que hoje em dia ele só está lá só orientando o curso. Mas assim, quando ele era mais severo, na atividade dele que ele priorizava aquela seqüência de assuntos, atomística profundamente...E hoje em dia a gente sabe que não é por aí. Que o aprender macroscópico é muito mais significativo a princípio do que o microscópico, que vai seguindo adiante. Então assim, eu comecei a ter uma luz: - Nossa! Se uma pessoa assim tão gabaritada está chegando a essa conclusão, então eu não estou sozinha. Então a gente começou a questionar muito isso daí e viu que a educação mudou um pouco. A educação Química tem mudado bastante, principalmente no que diz respeito à seleção de conteúdos, né. $E$ o que pega agora é que infelizmente a maioria dos didáticos que já existe não está de acordo. Então prá você estar realmente reformulando suas aulas de Química de acordo com a quantidade das aulas que você tem dentro da escola, com tempo, quantidade de temas e quantidade de tempo, você enquanto profissional tem que estar montando o seu trabalho, o seu material de trabalho. E esse é o tempo que o professor da rede pública não tem ou outro professor também qualquer não tem.

$P$. Então hoje você se permite mexer nessa seqüencia de conteúdos? 
P1. Hoje eu me permito. Sem assim dor na consciência. Porque antigamente eu ficava muito insegura. Eu seguia aquela seqüência de livros didáticos e muitas vezes, assim, eu cheguei numa certa fase que eu não ficava assim questionando com o aluno: Você está conseguindo? Até que ponto isto está sendo positivo prá você? Não, é aquela rapidez. Eu tenho que terminar isso, eu tenho que entrar naquilo e eu falava prá eles: Não vocês estão atrasados! Entendeu? Isso daí acaba estafando o aluno também, não é? Você está assim querendo que ele se torne uma caixa, está querendo colocar um monte de coisa ali dentro. E hoje em dia eu estou mais segura com relação a isso. Tanto que eu vou ser sincera prá você, não importa se eu não conseguir atingir todos os conteúdos, mas o conteúdo dado foi bem transmitido, bem trabalhado, que eu tenha um retorno positivo dos alunos, eu priorizo isso. 


\section{ENTREVISTA COM P2 (02 DE AGOSTO DE 2005)}

P. Você elabora o seu planejamento anual por necessidade ou para cumprir normas burocráticas?

P2. Sinceramente?

P. Isso sinceramente.

P2. [Para cumprir normas burocráticas. $]^{1}$

P. Então você não sente necessidade em fazer o planejamento?

P2. Infelizmente. [É uma necessidade] ${ }^{2}$, daí a [minha dificuldade muitas vezes de estar trabalhando com planejamentos] ${ }^{3}$, assim... tipo, a [dificuldade que eu tive de estar aplicando o projeto LabVirt, a principal dificuldade era planejar. $]^{4}$ Me planejar, então era uma dificuldade, eu comentei ainda isso com os amigos, com o Fabio e tal, porque [era uma dificuldade interna minha, de estar colocando no papel de estar planejando o trabalho. $]^{5}$

P. Então se não tivesse o planejamento você conseguiria dar aula do mesmo jeito?

P2. [Do mesmo jeito dificilmente não. $]^{6}$

$P$. Por que não?

P2. Por que assim, [você tem que ter um fio condutor] ${ }^{7}$, né, então você tem que ter mais ou menos. Então porque, aquela história, [a gente acha que já deu aula dez anos então não preciso mais planejar nada, e isso é mentira. $]^{8}$ Isso é mentira porque [a gente vê o quanto fica faltando, o quanto você poderia aproveitar mais o seu tempo. $]^{9}$

P. Esse planejamento que você faz burocrático, para a escola, você consulta ele ao longo do ano?

P2. [Poucas vezes. $]^{10}$

P. Você segue ele?

P2. [Não. $]^{11}$

P. Não segue?

P2. [Sigo o planejamento, sigo o que foi planejado] ${ }^{12}$, assim o que a gente colocou no papel, mas eu não carrego, eu [acho que eu deveria estar colocando no meu diário e estar ali no dia-a-dia. $]^{13}$ Eu acho que isso deveria ser o planejamento, e eu não faço isso.

P. Você elabora, você de certa forma planeja a sua aula para cada turma?

P2. [Planejo.] $]^{14}$

P. A aula prá cada turma é igual?

P2. [De jeito nenhum, não. ${ }^{15}$ Assim o que é igual são os tópicos que são iguais, mas a [forma de estar passando, até a maneira deles estarem escrevendo eu mudo totalmente. $]^{16}$ Então de uma sala prá outra muda completamente. 
P. E quando você planeja essa aula, você registra esse planejamento em algum lugar? Como que é feito isso, você planeja aula prá cada sala? Como que é feito esse planejamento?

P2. [Às vezes sim] ${ }^{17}$, [às vezes eu coloco no papel, monto apostila, quando é alguma coisa de diferente que eu queira fazer $]^{18}$, [mas no dia-a-dia, vai indo. $]^{19}$

$P$. A cada ano esse planejamento é o mesmo ou ele muda?

P2. [Muda, ele muda.] ${ }^{20}$

P. E o que você considera para mudar ele?

P2. Muda, ele [tem que ser partilhado com todos os professores da área] ${ }^{21}$, então [a gente procura estar fazendo com que os conteúdos batam de manhã e à noite] ${ }^{22}$, então isso [vai mudar de acordo com a realidade de cada turma.] ${ }^{23}$

P. Então, você falou que esse planejamento tem que estar de acordo com os outros professores. Então ele é discutido com os outros professores da disciplina?

P2. Sim.

$P$. Você acha que isso é necessário?

P2. Muito

P. Por quê?

P2. Exatamente por isso, [por que cada um tem o seu jeito de estar passando, mas o conteúdo acho que tem que estar... $]^{24}$ prá [não estar atrapalhando o aluno se ele passa de um horário pro outro, de uma escola prá outra. $]^{25}$ Acho que tem que ser mais ou menos, mais ou menos [porque a gente sabe que no final ele vai estar precisando de um conteúdo básico. $]^{26}$

P. Precisa de um padrão?

P2. [Tem que ter um padrão. $]^{27}$

P. Da escola inteira?

P2. [Da escola inteira ${ }^{28}$, [porque ele vai ser cobrado lá na frente, no vestibular ou em um curso que ele for fazer] ${ }^{29}$, [na faculdade dependendo da matéria que ele optar, ele vai ter que ter aquele mínimo] ${ }^{30}$, então aquilo [ele tem que ter ele tem o direito de ter isso.] ${ }^{31}$ Então assim é muito preocupante quando os professores acham que eu não preciso mais cumprir um programa, um currículo, e começam assim " Ah, hoje eu vou falar disso, amanhã eu falo daquilo, e aí eu estou fazendo uma aula diferenciada..." Acho preocupante isso, [a gente tem que garantir aquele básico e dentro do básico estar abrangendo outros assuntos. $]^{32}$

P. E aqui na escola o planejamento é seguido por todos?

P2. É. A gente procura, não é sempre assim, eu percebo que varia muito de escola para escola, já trabalho aqui há algum tempo, e não foi assim durante muito tempo, hoje a gente consegue estar caminhando mais ou menos, agora teve o re- 
planejamento, e nós sentamos e "Olha o que a gente fez de diferente?" então " O quê é que nos mudamos?" então "oh, isso foi invertido assim e assim, não sei o que, eu acabei esquecendo isso, não sei o que aconteceu..." e aí [a gente re-alterou o nosso planejamento, ele foi re-planejado mesmo. $]^{33}$

$P$. Foi registrado essas novas ações?

P2. [Foi registrado.]

P. Foi re-elaborado, foi registrado de novo? Esse re-planejamento ele é entregue para escola de novo?

P2. [De novo.] $]^{35}$

P. Então esse planejamento que eu tenho já mudou?

P2. Mudou alguma coisa, e eu não sei se já está... foi feito só um rascunho eu acho, não esta ainda em definitivo. Mas assim, as mudanças nós já fizemos.

P. E aí o que é considerado para re-planejar? Então o que os professores esqueceram? Se a turma avançou até que ponto?

P2. [Até onde eles conseguiram, se você conseguiu, o porquê você conseguiu, ou se não conseguiu] ${ }^{36}$ o porquê você não conseguiu, e isso é re-planejar mesmo.

P. E aí o que vocês fazem, por exemplo, vamos supor aqui, primeiro colegial tinha desde a história das ciências até funções inorgânicas e aí eles foram até elementos químicos, então ficou faltando ligações químicas, reações químicas e funções orgânicas. O que vocês fazem com essas três?

P2. No final do ano por exemplo, é isso que você quer dizer?

P. É pode ser. Ou então vamos dividir isso aqui por bimestre, vamos supor, a história da ciência vai da Química ao cotidiano no ensino de Química, então era para dar esses três, vai Química e noções fundamentais, e esse último não deu para dar, o que você faz com esse conteúdo que não deu prá dar?

P2. Continua, continua sempre, aí se acabar e não der tempo de dar funções inorgânicas aí no próximo ano, seria o correto, a gente estar retomando ali, em funções inorgânicas. Que [eu acho que deveria ser feito o planejamento no início do ano a escola tem que trazer e tem que saber até onde cada turma foi. $]^{37} \mathrm{E}$ eu acho que não tem essa ligação. Quando a gente tem professor que fica na mesma escola, que alguns anos atrás era possível, isso funcionava bem, então a gente conseguia passar um pro outro e era muito bom, hoje em dia não é assim, essa quebra que existe de o professor cada ano estar em uma escola é complicado. Agora acho que vai facilitar um pouco com os efetivos, fica mais fácil.

P. Você não acha que teria outra maneira de resolver isso, por exemplo, tem a quebra de professor, tem a falta de professor, a troca-troca. Vamos supor, eu entrei esse ano aqui, e o professor do ano passado não estava. 
P2. Aí [o professor planeja mais ou menos, sem conhecer os alunos] ${ }^{38}$, aí [ele entra na sala de aula e vai ter que conversar com os alunos, é o que a gente faz sempre $]^{39}$, ou pelo menos eu faço isso sempre, "Até onde vocês viram?", então "Vocês viram isso? Viram isso?..." e perguntar por que muitas vezes eles falam que já viram, mas não viram.

P. Ou então eles falam que não viram nada, mas já viram.

P2. Isso mesmo, então a gente tem que estar buscando deles, de onde eles viram prá onde eles foram. Que foi o caso esse ano do terceiro colegial, eles não chegaram... foi programado o primeiro bimestre para estar trabalhando com gases e eu a Kelly as duas esqueceram e o Fabio trabalhou gases.

P. Vocês não trabalharam?

P2. Não, então a gente vai ter que nessas turmas, a gente re-planejou isso, nessas turmas o conteúdo de gases vai ficar no final.

P. E vai ter que ser...

P2. Dado.

P. E vocês esqueceram talvez porque vocês não tinham o planejamento na mão.

P2. Exatamente, eu falei que comi bola legal, eu esqueci, e a Kelly também esqueceu e o Fabio fez direitinho.

$P$. Porque você não guarda o planejamento que você faz?

P2. Eu acho que é... como é que a gente fala... [falta de organização. ${ }^{40}$ [Eu não sou uma pessoa organizada, e isso me atrapalha $]^{41}$, então exatamente por isso, quer dizer eu sou organizada na minha bagunça, eu sei de tudo... entendeu? Eu não faço as coisas por fazer, mas eu sinto a necessidade de estar me organizando, de poder seguir direitinho, e isso é um aprendizado que você tem que... o LabVirt esta me ensinando isso entendeu? Por isso que eu quero continuar trabalhando, porque assim é muito melhor, [eu senti que é muito melhor você seguir um planejamento ali aula a aula.] ${ }^{42}$ [Você vai segura, você termina segura. $]^{43}$

P. Aqui na questão cinco você eu pergunto assim: "Quais itens devem ser pensados para se elaborar um planejamento?" daí você me colocou: "A realidade da escola, da clientela e seguir os conteúdos básicos", então como esses itens são considerados no planejamento? Como é que você considera a realidade da escola no planejamento? Como é feito isso?

P2. Eu preciso saber como é, agora que eu tô em outra escola que é completamente diferente eu sinto essa necessidade, então eu [preciso conhecer como são os meus alunos] ${ }^{44}$, [de onde eles vêm, se eles trabalham ou não trabalham, eles moram aqui perto ou moram longe] ${ }^{45}$, eu acho que tudo isso faz a diferença, porque [a gente tem que ver qual o objetivos deles, então a gente tá trabalhando para a formação 
desse aluno] ${ }^{46}$ não é? Então a gente tem que saber o que ele quer, o que ele está buscando, então [se a gente acha que eles estão buscando alguma coisa muito que deixa a desejar a gente tem pura obrigação de estar ampliando os horizontes desse aluno $^{47}$, então a partir daí que eu falo que a gente tem que conhecer a clientela, e [quando a gente não conhece a clientela a gente tem as dificuldades.] ${ }^{48}$ Eu falei da clientela, falei da realidade da escola, então [como que a escola trabalha] ${ }^{49}$, tem escola que abre para a comunidade, quando a escola é aberta para a comunidade é muito mais fácil trabalhar com o aluno, o aluno se sente parte integrante daquela comunidade, daquela escola, ele gosta e começa a participar muito mais. Quando a escola é fechada ele começa a depredar, pichar, entendeu? Eu senti que nessa escola nos tivemos momentos diferentes, e a diferença é muito grande, eu tive momentos que era aberto, momento que fechou de vez e a diferença é muito grande.

$P$. Essa questão de seguir os conteúdos básicos?

P2. [Esses conteúdos que eu acho que ele tem direito, ele tem direito ele tem que estar garantido o ensino. ${ }^{50}$ Eu acho que ele precisa, que [a gente não pode fugir do básico necessário prá ele] ${ }^{51}$, nesse ponto que eu falo de conteúdo, [não que eu falo que tem que seguir o livro didático, não é isso, mas existe um mínimo necessário que ele tem que aprender. $]^{52}$

P. Fora esse, quais itens mesmo você acha que tem que constar em um planejamento? Como objetivo e tal, o que você acha que seria importante hoje, você vendo que planejamento é uma ferramenta importante para o professor. Se você tivesse que pensar nele, que elaborar ele, que itens você acha que não deveriam faltar para ficar um planejamento completo, claro?

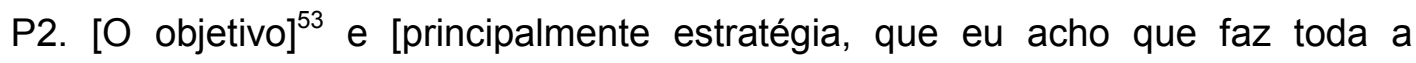
diferença.] ${ }^{54}$

P. Estratégia que você diz é a metodologia?

P2. [Metodologia, como você vai passar esse conteúdo, de que forma.] ${ }^{55}$ Levando em consideração a minha sala, a realidade dos meus alunos, o que eles querem, se eles são agitados se eles são parados.

$\mathrm{P}$. Você conhece o PCN?

P2. Conheço.

P. Já leu ele todo direitinho?

P2. Já.

P. O que você acha dele? É uma coisa possível? Não é possível? Está de acordo?

P2. Eu acho que é possível. Agora dentro do ensino de Química a gente tem poucas aulas, então assim tudo aquilo seria possível se a gente tivesse mais tempo, 
porque nessa escola a gente ainda tá sendo favorecido por causa do módulo, mas numa escola que tem as aulas pulverizadas é muito difícil, muito difícil estar trabalhando tudo, você trabalha um pouquinho.

P. Levando em consideração essa coisa que você fala de conteúdo básico, como é que, por exemplo, no planejamento de vocês não consta radioatividade por exemplo. Como é feita essa seleção de conteúdos? Como é que vocês selecionam uns e não outros? No que vocês se baseiam? Como é que vocês consideram os conteúdos básicos? De onde vocês tiram que esses são conteúdos básicos e não os outros?

P2. Inclusive isso foi uma das discussões, porque eu fiquei brava de não ter radioatividade só que a gente tem que entrar em um acordo, porque eu acho que principalmente agora é importante a gente estar falando, porque é um assunto que está pipocando por aí em todos os lugares. Eu acho que [a gente tem que estar pegando os conteúdos principalmente que tá no dia-a-dia, atual $]^{56}$, e radioatividade era um dos que assim eu queria que tivesse e não tem. Então eu fiquei assim "Vamos trocar gases por radioatividade?" por que eu acho que gases não é tão importante. Então a gente discute esses assuntos levando em consideração, e aí vai pela maioria, por que não pode ter um planejamento diferente prá cada turma. Mas é discutido e foi discutido.

P. E aí consideram como para selecionar, por exemplo, esses conteúdos nessa seqüência?

P2. Ah tá, [nessa seqüência acho que até por uma comodidade] ${ }^{57}$, acho que [0 livro didático traz nessa seqüência. $]^{58}$ Embora a gente já tenha trabalhado aqui com o mapa conceitual, nós fizemos um ano, e é difícil trabalhar com ele, porque às vezes a gente não esta acostumado, e eu tô vendo que nessa minha intenção de trabalhar com o programa é mais ou menos o mapa conceitual que no primeiro ano trabalha com matéria do segundo de terceiro e eu acho que é essa idéia de estar puxando de estar misturando as coisas, então é falta de hábito mesmo de estar moldando, então fica muito mais prático, que a gente já está acostumado assim. A gente também [trabalha com a proposta educacional da CENP do livrinho verde $]^{59}$. Eu desde quando comecei a trabalhar, dando aula, eu utilizo o livrinho verde como referência, muito mais do que os livros didáticos, não fogem muito disso, não foge muito disso não.

P. Qual é a sua concepção de ensino?

P2. Prá mim, [eu acredito que o que eu estou ensinando tem que fazer parte da vida do meu aluno, tem que ser interessante para o meu aluno] ${ }^{60}$, eu tenho, [tenho por obrigação de acrescentar algo para ele, mesmo que seja mínimo ${ }^{61}$ que [tenho que mudar alguma coisa nele] ${ }^{62}$, então prá mim ensino é isso, se eu conseguir que cinqüenta por cento da sala consiga entender alguma coisa, entender de que forma, de relacionar com o dia-a-dia dele, de ele poder exercer mesmo, eu falo muito isso, dele poder exercer a 
cidadania. Eu sempre friso isso: Qual é o principal objetivo do ensino de Química no ensino médio? Prá mim é fazer com que eles consigam no dia-a-dia deles, na vida deles, criticar, argumentar, entendeu? Questionar, discutir em cima, de que forma isso? Isso é treino, e eu só posso discutir aquilo que eu já ouvi falar, que eu ouvi dizer, que alguém me disse como é o correto. Eu até brinco com eles que eu digo "Olha gente isso aqui é um caderno, vocês estão vendo? Isso aqui é um caderno é vermelho é bonito." , "Professora você tá louca isso aqui não é um caderno, isso aí é um estojo" "Mas quem é que disse que isso aqui é um estojo? Então um dia alguém disse prá vocês que isso aqui é um estojo então a partir disso que vocês conhecem é que vocês podem estar argumentando seja com quem for" Por que? Por que você tem um conceito você tem um aprendizado.

P. Você acha que o seu planejamento está de acordo com essa concepção?

P2. Eu acho que... que o planejamento... é que cada um tem um método de dar aula, então a minha aula é de acordo com isso, com essa minha concepção, eu nunca fugi disso, inclusive o Fabio costuma brincar que ele aprendeu a dar aula, por que assim ele começou a dar aula e ele foi o meu estagiário, e eu sempre tive essa concepção, então assim a proposta de sempre trabalhar nessa linha, e eu acredito muito nisso, que você só aprende se isso for interessante prá você e se isso for te acrescentar em algo, se não isso fica, né... e ele acabou mudando bastante o jeito dele de dar aula também, então ele pega às vezes um aluno que vem da noite, passa prá manhã, ele pega o caderno olha e fala assim "Ah, ela trabalhou aqui..." tem muito professor que se fecha muito, medo de errar medo de mostrar a fragilidade, a Kelly me cobra muito isso, ela fala assim: "Você coloca demais..." e eu falo "Mas eu sou assim, se eu tenho dificuldade eu vou atrás, seu eu tenho medo eu vou e falo".

P. Como assim coloca demais?

P2. De abrir demais, que nem o fato do planejamento, eu cheguei pro Fábio outro dia voltando do curso e falei: "Fábio vou te confessar uma coisa, prá mim o mais difícil tá sendo planejar, eu não sou organizada então eu to brigando uma briga interna comigo" então ela achou que eu falei demais, entendeu? Mas eu sou assim porque só assim eu vou aprender. Eu preciso aprender, então eu não tenho vergonha de chegar de errar, de ir atrás, de buscar e de... entendeu? Eu não tenho, e eu acho que isso é que faz a gente crescer, e de buscar desafios.

P. Justamente prá você ter alguém prá te ajudar e ultrapassar essa barreira.

P2. Exatamente, e assim o Fábio me ajuda bastante porque ele tem esse dom, o dom da palavra, o dom de colocar no papel, eu não tenho isso, e ele me ajuda nisso, "Fábio eu quero assim, assim, assim", eu posso ter as idéias, eu posso fazer legal, mas eu na hora de colocar no papel eu não sei, na hora de falar eu não sei. 
P. Durante a sua formação foi discutido ou ensinado algo sobre planejar? Planejamento? Planejar? Você lembra?

P2. Prá ser sincera, [acho que muito pouco] ${ }^{63}$, Prática, né PEC, Prática de Educação ou de Ensino... alguma coisa assim. Muito pouco eu não tive muito. Mas o que acontece? Na época que eu fiz o curso, eu jamais queria dar aula, então prá mim isso era... então as minhas aulas de Didática, a minha professora era bárbara, olha eu gostava muito dela, e hoje eu vejo assim a falta que me fez as aulas de Didática, então se o professor pudesse estar estagiando enquanto né, estudante mesmo, nossa... alguns tiveram essa oportunidade, mas isso seria bárbaro, eu tenho vontade de voltar a estudar por causa disso, porque assim você muda completamente, você tem um objetivo, e na época que eu fiz a faculdade eu não tinha objetivo de dar aula, eu queria trabalhar na indústria, e aí eu falava pro meu professor "Eu nunca vou dar aula na minha vida, nunca" e aí dois anos depois de formada encontrei com ele e falei assim "Preciso te contar uma coisa" e ele falou "Já sei você tá dando aula" eu confirmei e ele falou "Tá vendo, eu não falei" e me apaixonei, porque eu me descobri.

$P$. Você chegou a trabalhar na indústria ou não?

P2. Trabalhei mas não..., trabalhei, fazia estágio assim, mas nada certo, eu trabalhava numa indústria química num departamento de marketing e estagiava no laboratório, mas eu não cheguei a trabalhar definitivamente no laboratório porque eu acabei saindo.

P. O que te levou a dar aula?

P. A necessidade, a primeira coisa assim foi a necessidade, mas a pior, o que me segurou muito foi a insegurança, aquela coisa ah eu acho que eu não sei, eu morro de vergonha, eu não conseguia falar em público, nossa era uma coisa assim, aí eu passei por uma fase meio complicada e eu precisava trabalhar, e eu fui pegar uma aulinhas a noite, minha cunhada trabalhava aqui, e falou que estavam precisando de professor de matemática, tanto que eu comecei com aula de matemática que eu me sentia mais segura, Química de jeito nenhum, e comecei com aula de matemática numa licença de quinze dias, e estou há quase quinze anos já, não parei mais, porque eu me apaixonei, sabe é uma coisa assim, e larguei o que eu fazia, eu era secretária, eu larguei pedi exoneração, eu optei por dar aula, por que é uma coisa assim, e você fala assim "Você pretende fazer coordenação?" Não eu quero trabalhar com os meus alunos, eu sinto a necessidade de estar com os meus alunos, de tá no dia-a-dia com eles, de saber como é que eles são, de saber o que eles estão entendendo. Os professores não imaginam o quanto nós somos importantes prá eles.

P. Quanta influência. 
P2. Quanta influência, e eles acham que não. Então quanto professor é exemplo ainda, e há necessidade de o professor tá tendo uma linha, uma postura, uma ética, ainda nos dias de hoje o professor é exemplo, e eu acredito muito nisso.

P. No início do ano, antes de você saber o planejamento, ou logo em seguida, é feita uma avaliação diagnóstica com os alunos?

P2. Como assim? Antes de planejar?

P. É, aqui você me coloca assim: "Sim, logo no início das aulas".

P2. Então isso é o que eu faço.

P. E como que é feita essa sua avaliação diagnóstica?

$P 2$. De estar questionando, de [saber que matéria já foi dada... $]^{64}$

P. Então não é uma coisa formal, no papel?

P2. [Não] ${ }^{65}$, eu já fiz, eu já fiz, mas [eles têm mais dificuldade de colocar no papel, de estar registrando] ${ }^{66}$, eu já fiz.

$P$. Então como você faz?

P2. Eu mesma vou conversando, "Ah, vocês já tiveram isso? De onde veio? De que escola veio? O que aprenderam? Vocês tiveram aula de Química?" muitos não, muitos vieram de outras cidades, de outros estados, ou vieram de outra escola que não teve professor o ano inteiro, então não sabe nada, e aí como é que eu vou fazer? [Eu vou ver a maioria, e pela maioria a gente vai caminhar. $]^{67}$

P. E aí você dá uma olhada no seu planejamento prá ver se tá de acordo ou não?

P2. Então porque esse planejamento na verdade a gente acaba entregando depois né, [a gente discute, faz um rascunho e depois a gente entrega] ${ }^{68}$, então tanto é que eu [acho que esse foi entregue quase em maio, então até maio a gente teve tempo de estar mexendo nele.] ${ }^{69}$

P. Você já falou um pouquinho disso, agora vamos fazer formalmente. Como está sendo ter que planejar as aulas do LabVirt? Você acha que é necessário?

P2. [Muito difícil] ${ }^{70}$, [muito, muito complicado prá mim.] ${ }^{71}$

$\mathrm{P}$. Onde você sente essa maior dificuldade?

P2. Registrar, [o registro prá mim é muito complicado, inclusive quando eu vou registrar as minhas aulas no diário] ${ }^{72}$, então prá mim isso [é complicado, de estar registrando e de assim, de tá organizando o meu tempo. $]^{73}$ Eu já consigo algumas vezes eu consigo terminar o meu módulo com o meu diário fechado, que seria o correto. $E$ às vezes eu não consigo.

P. Por quê?

P2. Por que falta de planejamento, então [eu percebi que se eu planejar aula a aula, que é muito mais difícil, eu gastar esse tempo todo planejando, depois no decorrer é muito mais simples, muito mais seguro, muito mais fácil, flui muito melhor. $]^{74}$ 
P. Você sentiu isso?

P2. Muito, muito, prá mim o registro é muito mais difícil.

P. Então assim ele auxilia ou ele dificulta essa sua prática?

P2. [Auxilia muito] ${ }^{75}$, muito, então assim o que acontece? [Isso é questão de hábito] $^{76}$, [é muito difícil no início, mais eu preciso ir fazendo, ir fazendo, até que vai chegar um momento.... $]^{77}$

P. Você seguiu ele ao longo da semana?

P2. [Do LabVirt sim.] ${ }^{78}$

P. Além dessa dificuldade de registrar, você sentiu alguma outra dificuldade nele? O que dificulta estar elaborando ele, além do seu problema com registro tem alguma outra coisa que possa dificultar estar elaborando esse planejamento aula a aula?

P2. Você tem que tá contando com imprevistos, acho que isso tem que tá claro, só, acho que nada assim. Não sei se é o porquê foi o primeiro que eu apliquei e foi tudo tão redondinho, foi muito certinho, então assim eu não sei como vai acontecer nas outras salas.

P. Mas prá você no dia-a-dia, você poderia estar fazendo esse planejamento?

P2. [Poderia estar fazendo isso nas minhas aulas normalmente.] ${ }^{79}$ Só que aí, [a gente tem que ter mais tempo prá estar elaborando, coisa que a gente não tem. $]^{80}$

P. Então falta tempo?

P2. Tempo, a gente não tem esse tempo prá estar elaborando, a gente não tem a disposição das pessoas de estar fazendo isso junto, eu acho que as divergências acontecem, e é complicado você lidar, cada um tem um ponto de vista, cada um tem seu objetivo e aí fica meio que na saia justa. Eu acredito na educação e eu vivo isso, isso é importante prá mim, prá um outro pode ser que não seja.

P. Mas aí no aula a aula você pode estar liberando esse outro, poderia ser só você.

P2. É poderia.

P. Você acha que a prática disso, poderá fazer com que você faça isso futuramente ou não?

P2. Eu acredito que sim, eu acho que assim, que o ser humano e o professor também e o aluno também, é igual aluno né, quando a gente fala que o professor é igual aluno, e é igual. O professor também tem que ter alguém ali por trás cobrando, então eu tive uma diretora, que tudo que eu sei eu aprendi com ela, então assim ela é uma pessoa que acredita muito na educação, acredita no ser humano, trabalha em pró do ser humano e ela encaminha os professores para essa linha, e ela fazia no planejamento, ela fazia assim a gente fazer um quadro, e era difícil, nossa era um horror prá gente trabalhar porque você não tá acostumado, prá que você vai ensinar isso, e como, de que forma? 
Então planejamento era assim com ela, não era isso, não era senta lá em grupo você faz o seu planejamento e pronto acabou, não, era discutido com a direção, com a coordenação, hoje eu não sei como é na escola dela, ela é diretora de lá. Mas era assim, e foi assim que eu aprendi, então eu tive muita sorte de ter pessoas maravilhosas do meu lado que me ensinaram tudo isso que eu ainda carrego, e que ao longo do tempo acaba fugindo um pouco porque você não tem aquela cobrança, alguém te cutucando ali prá você fazer.

P. E aí cada escola também tem o seu estilo, e tem que seguir aquele estilo né?

P2. É, mas eu acho que vai muito de direção, eu acho. Porque quando você visa o seu planejamento assim, você visa o seu aluno, você acha que a comunidade é uma coisa muito maior, então você está vendo toda a sua comunidade, que é assim, que essa pessoa ainda trabalha.

P. Como é que você considera o vestibular? Ele é importante pro seu planejamento, prá sua prática? Ou você não considera o vestibular? Que assim eu entendi que você considera o objetivo da comunidade, o objetivo dos alunos a realidade deles e tal. Então o vestibular não faz parte do seu planejamento?

P2. Sim faz parte quando eu seleciono o conteúdo mínimo.

$P$. Então ele é uma das referências?

P2. [Sim. $]_{81}$

$P$. Então não é só o CENP?

P2. Não, mas a proposta do vestibular está mudando né, eu acho que tá assim aquela parte, não muito mais ele tá, aí eu sempre falo pro meu aluno, deixo muito claro isso, "Olha você não vai sair daqui apto prá prestar vestibular" eu deixo muito claro isso "Se você quiser fazer vestibular, você vai ter que, você vai ter condições prá estudar, to te dando subsídios prá você ir buscar, se você estudar, ou você vai ter que fazer um cursinho à parte, por que você não vai sair com condições da minha aula prá prestar vestibular" eu sou muito clara com eles. Então eu viso sim o básico do básico.

P. E as suas referências prá ensinar Química? Onde você busca quando você fala assim "ah eu preciso estudar e tal" , rever prá poder ensinar, porque a gente esquece muita coisa mesmo. Onde você busca referência bibliográfica? Quais são as referências bibliográficas prá ensinar? Não aquela que o aluno usa, aquela que você usa, por exemplo quando vai ensinar amina, onde você vai buscar sobre amina prá você preparar a sua aula?

P2. Eu busco em [alguns livros didáticos mais atualizados] $]_{82}$, eu tenho alguns que eu gosto muito, então assim [a gente tá tendo alguns livros que tá trazendo assuntos mais fáceis de trabalhar] ${ }^{83}$ então [a gente tem hoje em dia os livros que tem a proposta dos PCN's] ${ }^{84}$, então esses livros eu pego e [algumas vezes alguns sites que eu vou atrás 
de pesquisa] ${ }^{85}$, ou mesmo alguns alunos, às vezes eu não tenho tempo, não tenho acesso então eu peço pros alunos o que eu quero e eles trazem às vezes, [a revista Nova escola] ${ }^{86}$, ou melhor a [Veja na sala de aula $]^{87}$, a gente recebe aqui, então eu pego alguns textos de lá, eu trabalhei bastante, bem legal.

$P$. E quais são os seus livros didáticos que você diz que são mais na proposta?

P2. Que eu gosto de estar trabalhando, o Usberco - Salvador, Tito e Canto que são os meus preferidos, a partir deles eu vou buscar os outros, gosto muito do jeito que eles abordam a Química.

P. Vocês usam livro aqui?

P2. Não.

P.Você dá aula com matéria na lousa?

P2. Com matéria na lousa e dificilmente eu uso o mesmo livro, então às vezes eu vou prá sala de aula e aí vem o que dificulta, a falta de planejamento, então eu vou com um monte de livro, então cada hora eu uso um, prá pegar exercício, prá ver o que tá diferente, só que no módulo ainda dá prá eu fazer isso, na aula pulverizada não dá, na aula pulverizada você tem que ter a coisa mais organizada.

P. Porque lá na hora é que você abre o livro e vê o que você vai dar?

P2. Eu tenho mais ou menos já... por que eu já tenho... mais é mais ou menos isso, se eu quero alguma coisa diferente eu já pego.

$\mathrm{P}$. Tem mais alguma coisa que você gostaria de me falar? Sobre planejamento? Algumas coisas que vocês colocaram? Alguma coisa que você não concordava? Alguma coisa que faltou?

P2. Nesse planejamento eu coloquei aqui algumas coisas que eu tento fazer. Experimentos em sala de aula, poucas vezes eu consigo, daí poucas vezes eu consigo, não que eu nunca faço, mais é pouco, gostaria de estar fazendo mais, e eu não sei se acontece isso nas outras aulas, daí a minha vontade de estar fazendo curso no GEPEQ porque ele vai me dar um subsídio maior de estar trabalhando isso em sala de aula, eu quero em sala de aula não em laboratório, em sala porque eu acho que dá prá trabalhar em sala, porque tem escola que tem, a gente tem laboratório aqui mas não é utilizado, eu acho mais fácil ir lá com seu material levar e fazer eu acho que funciona muito melhor. Excursões prá indústrias, eu morro de vontade, já fiz aqui, prá visita em empresa em indústria, e é muito difícil de conseguir que a direção libere prá gente tá saindo com o aluno, então isso eu sinto falta, todo ano eu coloco, mas acho que nessa gestão eu não vou conseguir, já fui até Cubatão na Petrobras de lá, mas eu acho que há oito anos atrás, que eu consegui levar os meus alunos do noturno, no sábado acho que foi durante o dia. Só esses dois que eu não consigo trabalhar, o resto eu trabalho legal, e exposições em eventos ligados... e eu tenho um sonho, que eu trabalhei no particular isso e é muito legal 
de tá fazendo uma, comentei esse ano, chamar de sala aberta ou exposição, mas assim um negócio concreto, de por a mão na massa e fazer, então assim eu já tive oportunidade de fazer no particular, claro que envolve tempo, dinheiro, você tem que trabalhar muito mais além, e você não tem pessoas, porque sozinho não dá prá fazer, que queira abrir mão do seu tempo fora de aula prá tá fazendo isso, entendeu? Você precisa, você vai gastar dinheiro, você vai gastar dinheiro do seu bolso, pode até conseguir com a direção com os alunos, mas é muito difícil, é muito trabalhoso, mas eu não consigo e eu tenho vontade de fazer isso, e eles adoram, eles trabalham e aprendem muito, eu fiz uma estação de tratamento de água numa sala de aula maravilhosa, fiz uma de tratamento de água, uma de tratamento de esgoto e a outra de água mineral que ficou bárbara e eles foram na CETESB eles pesquisaram, na SABESP eles foram, eu tinha uma caixa de água de quinhentos litros na sala de aula, simulando a estação de tratamento, então foi muito válido, eu aprendi muito com isso, eu aprendi coisas que eu nem sabia, e eu acho que isso é muito importante, eu tenho como sonho, e eu não consigo nunca alguém que queira me ajudar a fazer isso, então aqui, feira de ciências todo ano eu ponho, que eles chamam de sala aberta, feira de ciências, eu não consigo, então essa é uma das coisas que me angustia mesmo. Por que eu só consegui na partícular porque nos éramos obrigados mesmo, nos tínhamos a direção, tinha dinheiro, tinha tempo, a gente ganhava prá tá fora do horário. Mas eu acho que se você não acredita no que você faz, se você não se doa, esperar que o outro reconheça não dá, não dá. E aí é onde eu brigo. Então o pessoal fala que eu sonho muito, eu já briguei muito, já coloquei as minhas idéias, já falei, e o pessoal fala "Essa daí tá em outro mundo... essa daí não precisa dar aula... ela dá aula mas ela não precisa do dinheiro..." e não é isso eu tenho outra visão, a última coisa que eu vou ver é o meu salário, não dou aula pelo que eu ganho, eu dou aula porque eu gosto, porque eu acredito, hoje eu sou obrigada, tive que entrar numas de me calar. Na minha aula eu procuro fazer do jeito que eu acredito, mas assim eu queria muito mais, mais não dá. 


\section{ENTREVISTA COM P3 (16 DE MARÇO DE 2005)}

P. Eu quero que você me conte a sua trajetória até chegar a ser professor. Como é que você chegou a ser professor. Você fez Química? E como é que você chegou a ser prof. $^{\circ}$ de Química?

P3. Primeiro fiz faculdade, com interesse em fazer a faculdade de Química pela minha professora de Química do colégio. Que ela me incentivou bastante nessa área.

P.Você sabia Química no colégio?

P3. Sabia

P. Aprendia?

P3. Eu era meio CDF em Química. Pelo menos em Química. E aí gostei, principalmente do magistério de Química, ela me despertou bastante coisa. Foi que eu fiz a faculdade. Aí quando eu estava no $3^{\circ}$ ano da faculdade, do $2^{\circ}$ pro $3^{\circ}$ ano da faculdade, a gente teve um problema financeiro bem sério aqui em casa. $E$ meu pai praticamente obrigou todo mundo a ir trabalhar. Até então ele bancava a faculdade, todo mundo estava bem tranqüilo. Daí, eu comecei a dar aula, meio despropositado assim. Porque na faculdade já tinha despertado interesse em pesquisa, eu estava fazendo iniciação científica. Uma série de coisas prá seguir prá outra área da Química. Mas aí no $3^{\circ}$ ano aconteceram estes probleminhas aqui em casa, e eu tive que fazer alguma coisa prá começar a trabalhar. Então foi quando eu comecei a dar aula. Terminei a faculdade, fiquei um tempo ainda no laboratório de iniciação científica da faculdade, mas depois em 1998 eu falei: - Não! Vou seguir a educação. Fiz a minha Licenciatura em 2000, e foi só sala de aula de 1997 prá cá.

P. Então você terminou bacharel e depois você fez a Licenciatura porque você já estava dando aula?

P3. Hum, hum. Como uma obrigação. Se não eu não poderia continuar na escola.

$P$. Isso. E como é que você veio a ser coordenador?

P3. Coordenador foi mais complicado. Porque de 1997 a 2000 a gente tinha uma coordenadora à noite, a prof ${ }^{a}$ Vânia, e em 2000 ela saiu da escola e em 2001 a gente iniciou o ano sem coordenador. Então a minha diretora propôs: - P3, presta a prova. Você já conhece a escola, já conhece os alunos, o período noturno você já conhece bem, presta a prova prá ver se você vira nosso coordenador. Então eu falei: - Bom, posso prestar sem compromisso nenhum. Prestei, passei. Apresentei a proposta, estava concorrendo com mais 5 colegas de outras escolas, fui aprovado, aí em 2001 eu entrei assim, meio de sopetão. Não estava meio esperando, mas entrei na coordenação e estou aí até agora.

P. Quatro anos já praticamente de coordenador do noturno? 
P3. Quatro anos. E todo ano eles me reelegem, me referendam e falam: - Não, continua, continua, continua... E eu estou aí ainda.

P. Mas você gosta?

P3. Gosto. Tem muita coisa que você faz. A gente costuma brincar que a gente é desviado da nossa função de coordenador prá uma série de coisas. Desde cuidar de aluno no corredor...

P. Brincar não, é sério isso.

P3. E a gente faz tudo na escola, menos ser coordenador. Mas mesmo nessa correria toda a gente tem muito gosto. Pelo menos eu me realizo bastante. Que é um tempo que a gente para prá orientar, a gente tem tempo de preparar melhor uma atividade, não prá minha sala de aula, mas pros professores que trabalham comigo. Então é bem legal ser coordenador, eu não reclamo não.

P. E de ser professor?

P3. Às vezes dá um desgaste. Principalmente esta semana que eu estou entrando às 7 horas na manhã e saindo depois das 11 (da noite), tenho este período da tarde livre, mas desgasta um pouco, a gente às vezes desanima, mas...o que eu nunca perco em mente quando eu estou na sala de aula é a responsabilidade que eu tenho na vida dos pequenininhos que estão ali dentro, eu chamo todos eles de crianças, porque é muito grande, então a gente não pode desanimar. Eu não me permito desanimar por causa disso, porque eu sou responsável, não só pela formação, mas... é.. . parece meio utópico, mas pelo que essas crianças vão ser prá frente, então de passar valor além da Química, de passar o jeito de tratar com as pessoas, então tudo isso eu levo bastante a sério. Então a gente passa por cima de um monte de coisa, da indisciplina, da falta de compromisso, da falta de interesse, mas por esse lado responsável que eu tenho com eles. Porque eu me sinto muito responsável assim.

P. E você pensa em sair da sala de aula?

P3. Não totalmente. Pode aparecer alguma outra coisa prá fazer...Há dois anos atrás eu comecei uma faculdade de farmácia, porque meus pais têm uma farmácia, já prá trabalhar nesse ramo também, mas eu precisei largar a faculdade, mas num, num...Deixar a sala de aula, eu não deixo não. Mesmo que eu me esquematize numa coisa na minha vida, pelo menos 4 aulinhas por semana eu tenho que ter que é prá...

P. Será?

P3. ...Garantir o tino. Fico, fico.

P. Por que você, como coordenador pedagógico, resumiu o planejamento a uma seleção de conteúdos?

P3. Então, a gente... Até o ano passado a gente pedia para os professores fazer um documento mais completo envolvendo... Bom, como esse que eu te mostrei. 
Envolvendo proposta, objetivos gerais, objetivos específicos, além do conteúdo programático. Para esse ano a nossa proposta, na verdade [foi uma sugestão da direção, ela passou prá gente da coordenação antes da semana do planejamento, que ela queria dar uma padronizada na questão dos conteúdos] ${ }^{1}$. Que [a gente tinha um sério problema, apesar de estar tudo documentado, dos professores, de manhã e de noite trabalharem diferente $]^{2}$. Então a gente remanejava o aluno, tinha problema. No meio do ano teve ingresso de efetivo, então professor do colegial teve que ser remanejado pro ensino fundamental ou vice-versa. E a gente viu, teve um caso de um professor de matemática que estava na $7^{a}$ série e de repente foi pro $1^{\circ}$ ano com esse ingresso, e os alunos do $1^{\circ}$ ano começaram a reclamar que ele estava dando a matéria da $7^{a}$ série. Então a gente teve muito problema com essa questão do conteúdo. Então no nosso planejamento esse ano, a gente fundamentou em cima de projetos, a gente fundamentou em cima de um monte de coisas, mas prá escrita o que é que a gente pediu pros professores? Padronizem a relação de conteúdos. Então [a gente queria mesmo padronizar essa questão do conteúdo. Que os professores falassem a mesma linguagem] $]^{3}$. A gente foi questionado por que [é um documento muito vago] ${ }^{4}$. Os professores mesmo estranharam, porque foi fácil de elaborar. Então por exemplo, a gente passou dois dias planejando uma série de atividades prá escola, estudando um monte de alternativas prás disciplinas, fazendo trabalho com professores de áreas diferentes e no último dia, nas duas últimas horinhas, cada grupo de professores da área sentou e pau nesta listinha que eu te mostrei lá no Labvirt. E eles estranharam se ia ser só isso, o que eles poderiam estar fazendo a mais. Mas o grande mote que a gente deu prá esse ano é que prá cada módulo a gente elaborasse um documento de seqüência de aulas, como esse que a gente planeja pro Labvirt, que os professores estivessem pensando antes de começar o módulo, aula a aula, como é que ia ser. Então $1^{\circ}$ dia, $2^{\circ}$ dia, $3^{\circ}$ dia...Aí fica a cabo de cada professor.

P. Foi uma sugestão?

P3. Foi uma sugestão. Eles não têm o compromisso de estar entregando prá gente. Como eu faço pro Labvirt também não levo prá minha coordenadora do dia. Mas eles planejam aula a aula o conteúdo, em cima do conteúdo programático. As atividades, tudo isso, aí eles estão planejando paralelamente. Mas não tem um planejamento com objetivos, ... como foi feito até o ano passado.

P. Você coloca que o planejamento da sua escola é elaborado em cima do conteúdo para padronizar e num outro momento baseado no conteúdo programado 
elaborando propostas de atividades. Estas propostas de atividades são os projetos que você falou?

P3. Isso. No $1^{\circ}$ bimestre, no $3^{\circ}$ ano, é trabalhado o estudo dos gases. Em cima disso eu planejo as atividades do LabVirt, de uma sala aberta, alguma coisa assim. Em cima dos conteúdos programáticos.

P. Esses seus planejamentos de módulo, de temas, você registra ou não?

P3. [Eu registro] ${ }^{5}$. Eu registro agora, não na exigência do Labvirt, mas [é mais organizacional] ${ }^{6}$. [Facilita mesmo ter esse registro, módulo a módulo, das minhas aulas] ${ }^{7}$. E foi uma orientação que nós passamos pros professores também. Em cima do conteúdo programático estar registrando essas atividades aula a aula. O que foi feito na aula 1 ou o que será feito na aula 1, e assim por diante prá gente poder ter um registro das atividades. Faz o conteúdo programático e depois vai planejando bimestre a bimestre o que vai ser feito.

P. Você fala que "o planejamento padroniza a prática". Em que sentido ele padroniza a prática?

P3. [Professores diferentes, no mesmo nível de ensino, com o mesmo conteúdo], por que [a prática é individual de cada um] ${ }^{9}$. Mas pelo menos em termos de conteúdo a gente vai garantir que a mobilidade de aluno garantiria a mesma continuidade no estudo.

P. Quando você coloca aqui "garantimos o maior aproveitamento dos objetivos idealizados". Esses objetivos são em cima de que?

P3. Bom, a gente tem uma clientela aqui na escola, no período da manhã e uns $50 \%$ do período da noite, que é uma clientela que quer seguir estudo no Ensino Superior. Então a gente baseia mesmo nesse objetivo. Até o nosso Projeto Político Pedagógico é bastante focado no prosseguimento dos estudos embora a LDB foque na instrumentalização do indivíduo prá sair do Ensino Médio autônomo capaz de entrar no mercado de trabalho. A gente... aqui na escola, a gente não perverte, mas a gente reverte um pouquinho a situação, prá subsidiar o aluno prá continuidade do estudo. Não só pro mercado de trabalho. Porque a escola estadual não tem oficina, não tem nada prá subsidiar efetivamente pro mercado de trabalho. Então [a gente prefere trabalhar numa forma que o aluno tenha subsídio para prosseguir o estudo $]^{10}$. Então a gente volta na mesma questão. Padroniza o conteúdo exatamente prá isso. Prá esse objetivo. [Fundamentar bem o aluno, teoricamente também, prá ele poder depois prestar um vestibular, prá ele poder encarar um cursinho com mais tranqüilidade] ${ }^{11}$. Pra não ter tanta surpresa no cursinho, por exemplo, e poder prosseguir os estudos dele. Esse seria o objetivo maior assim, que a gente resolveu padronizar os conteúdos esse ano. 
P. Quando você fala que você "replaneja, para melhor atender as necessidades específicas de uma turma ou momento", você replaneja antes, você deu uma atividade, você replaneja ou você replaneja no momento da aula?

P3. [Não] ${ }^{12}$, a aula.. é difícil mudar a aula assim. Porque a gente já tem as atividades, a gente já tem tudo mais ou menos esquematizado. Mas aconteceu uma coisa nesse módulo, por exemplo, na aula de ontem. Eu estava falando as características, macro e microscópicas dos gases, tal e soltei que até tem o vídeo do Discovery que chama Microcosmos, que é tudo filmado pequenininho, então é mais prá biologia. Mas a aluna pediu: - Professor a gente pode ter a oportunidade de ver esse vídeo? Eu falei: - Eu posso conversar com a professora Marlene, que é a professora de biologia deles, que ela passa prá vocês. - Ah, mas porque o senhor não usa o seu módulo? - Ah, a gente vai usar o Labvirt, vai consumir bastante aula, prá gente ter mais tempo [...] Então é nesse sentido do replanejamento. [Às vezes uma orientação, uma sugestão de aluno ou alguma coisa que surja no momento.... $]^{13}$ Por exemplo, amanhã estou assistindo o jornal antes de subir, aparece alguma coisa que dá prá encaixar na aula, então já planejo prá próxima aula estar levando essa informação pro aluno. Eu acho que isso é necessário, até mesmo prá contextualizar a aula, mas [não é muito de sopetão, não] ${ }^{14}$. Sempre...

P. Você coloca na questão 5 que os itens que devem ser pensados para fazer o planejamento são o conteúdo programático, a realidade da clientela e a especificidade de cada turma. Pensando na especificidade de cada turma, você acha que dá prá padronizar o conteúdo programático?

P3. [O conteúdo até dá] ${ }^{15}$.

P. Vamos supor, todos os $2^{\circ}$ anos estão trabalhando com o mesmo conteúdo?

P3. Eu acho que dá. [A gente tem como mexer aí, vamos dizer assim, na profundidade que a gente vai atingir nesse conteúdo] ${ }^{16}$. Porque a gente vai ter vários níveis até onde a gente pode chegar. Por exemplo, pegar a parte da termoquímica. A gente pode manter cálculos ou teorias mais superficiais ou conceitos mais superficiais ou abordar coisas mais pesadas. Isso foi uma experiência que eu tive o ano passado, que com duas turmas, nas minhas seis turmas, no $3^{\circ}$ bimestre, todas elas estavam vendo termoquímica comigo. A questão da matemática aplicada a esse caso, eu até nem levo em consideração porque é necessária uma revisão de equação, uma revisão de sinal, uma revisão de isso ou aquilo. Mas, até onde você pode chegar, o tipo de problematização que você vai propor para uma determinada turma pode ser mais superficial e a outra você pode pegar mais pesado com eles. Então acho que é nesse caso que eu quis dizer a especificidade de cada turma. Se tiver uma diretriz, que é a relação dos conteúdos programáticos. Tanto que se você ler aquilo que a gente apresentou, é bastante genérico. Você tirar um bimestre só para termoquímica. Sendo 
que se você vai pegar o material didático de outras escolas você vê que eles sugerem que você trabalhe isso no máximo em 8 , em 7 aulas. Aí você pega 20 prá dar termoquímica, exatamente prá você poder flexibilizar o trabalho, prá você poder aprofundar mais. Poder ter um tempo maior de..., com a sala que tem mais dificuldade, você poder dispor de um tempo maior prá aprendizagem, prá poder subsidiar direitinho. Então é essa especificidade, nesse caso. Até onde você pode pisar com o aluno. Quão fundo você pode ir ou permanecer um pouquinho mais na superfície.

P. Você coloca que você seleciona os conteúdos de Química a partir das orientações dos exames oficiais, ENEM e vestibular. Essas três frentes sugerem os mesmos conteúdos?

P3. Então [quando a gente vê edital de prova, edital de tudo, a gente vê lá o que pede prá Química, o que estuda prá Química e geralmente não foge muito do que a gente trabalha na sala de aula ${ }^{17}$. Pelo menos os tópicos que aparecem lá. Pelo menos [os vestibulares, todos eles estão bem categóricos, então tem lá tudo que eles pedem] ${ }^{18}$. Quando a gente pensa em ENEM, a gente tem um problema sério em falar em conteúdo fechado porque o ENEM é uma prova que mexe mais com as competências do que propriamente com decoreba de conteúdo. Mas mesmo assim, analisando as provas do ENEM a gente vê que uma questão simples, que aparentemente não exige tanto conhecimento de conteúdo, vai englobar uma série de coisas que o aluno tem que saber... Não somente... A gente brinca: - Prá responder o ENEM é só ler a questão com atenção, você responde a prova. Tem muita coisa que é assim. Mas eu lembro até hoje que uma vez um aluno veio com uma prova do ENEM prá mim, uma questão de obtenção de hidróxido de sódio a partir do cloreto de sódio que envolvia uma série de reações com estequiometria, etc. Então [mesmo pro ENEM a gente tem que dar uma boa subsidiada de conteúdo pro aluno] ${ }^{19}$. [A gente tem que instrumentalizar o aluno nessa área, além é claro, de interpretação e daquelas várias competências que o ENEM pede] ${ }^{20}$. Por isso que [eu não tenho medo de colocar aqui, que um dos determinantes do meu planejamento é o ENEM] ${ }^{21}$. E eu falo pros meus alunos, o ENEM é interpretativo, o ENEM é bastante em cima das habilidades dos alunos, de leitura, de escrita, de atenção, de uma série de coisas. Mas também ele está focado no conteúdo, porque ele não vai deixar de lado. Eu até brinco com eles: porque se fosse só leitura e interpretação, estaria lá um texto que o ursinho Bilu usa calça azul e a primeira questão seria "Qual a cor da calça do ursinho Bilu?" Isso daí seria muito mais banalizada essa prova. Então precisa mesmo do conteúdo também pro ENEM, embora não tanto quanto pro vestibular.

P. Você coloca prá mim que "a cada ano o planejamento é o mesmo", porém a cada ano vem clientela diferente prá você. Então como é que você mantém esse planejamento padrão, todo ano sem mudar? Como é que você faz prá adequar isso? 
P3. Você está falando em pré-requisitos? O aluno chega...

$P$. Vem um aluno do $2^{\circ}$ ano prá você que não era do Laerte.

P3. Então ele teve uma seqüência lá que não necessariamente é a seqüência daqui?

P. Mas então independente disso você mantém um padrão de conteúdo? A escola mantém um padrão de conteúdo?

P3. Se eu falar que estou olhando a maioria vale?

P. Pode ser.

P3. Pode ser? Mas é meio complicado falar assim. Até uma visão meio egoísta da situação, mas acho que a gente..., a clientela muda sim. A gente recebe aluno novo todo ano. Mas nesse ponto realmente não tem um trabalho diferenciado prá esse alunado que chega não. Às vezes, não tiveram subsídios, não tiveram..., mas realmente nesse ponto a seqüência que a gente dá, $1^{\circ}, 2^{\circ}$ e $3^{\circ}$, os nossos alunos acompanham numa boa, tem a visão do conteúdo da Química pro Ensino Médio todinho. Mas caso o aluno..., eu já recebi aluno de $3^{\circ}$ ano no $3^{\circ}$ e $4^{\circ}$ bimestre, que tem escola que tira Química orgânica fora, e de repente eu estava lá em funções nitrogenadas e o cara "Pá" e o trabalho aí fica a parte, mas qualquer coisa que orientar a parte, vai buscar, pesquisar...Mas não tem assim uma, não vou dizer sem preocupação, mas essa visão não tinha me passado mesmo não. Poder ver, eu falar: - Se o aluno chegar nesse ponto sem isso, o que que eu vou estar subsidiando. Porque daí eu teria que estar deixando um trabalho que foi feito, alguma coisa assim. Só uma orientação paralela que poderia ser feita aí.

P. O que você entende por avaliação diagnóstica?

P3. Avaliação diagnóstica. Eu vejo... Ela pode ter duas interpretações. Mas quando eu penso em avaliação diagnóstica [eu vejo alguma forma de eu estar não medindo o conteúdo] ${ }^{22}$. [Não medindo o que o aluno sabe, mas como anda o processo de ensino-aprendizagem $]^{23}$. Eu acho que o diagnóstico, ele é mais nesse ponto. Quando eu penso em avaliação diagnóstica, [alguma atividade ou alguma prova, alguma coisa que eu faça em sala de aula prá medir quão eficiente está sendo esse processo de ensinoaprendizagem] $]^{24}$.

P. Então ela é feita durante o ano todo?

P3. [Isso] $]^{25}$. [É um bate-bola, às vezes uma conversa com os alunos, uma chamada oral] ${ }^{26}$ ou uma conversa mesmo que a gente tenha, prá medir se está sendo eficiente mesmo esse trabalho. Foi até uma discussão que eu tive com a Ana Néri lá na última, porque muita gente entende avaliação diagnóstica em cima do que o aluno..., [uma avaliação que eu vou ver o que o aluno sabe, antes de começar a planejar as minhas coisas. Isso eu já interpreto como levantamento de conteúdos prévios] ${ }^{27}$. Prá mim já é uma coisa completamente diferente. Eu posso fazer isso num momento específico, 
mas realmente isso aí prá mim não é avaliação diagnóstica. [Avaliação diagnóstica é do meu trabalho, do aprendizado do meu aluno] ${ }^{28}$. Então [são atividades que a gente consegue estar fazendo dia a dia, uma avaliação mais contínua, que me permite remodelar no que for necessário a minha prática $]^{29}$.

P. E essa avaliação inicial, você acha importante?

P3. Ah, o levantamento do que o aluno traz?

P. Isso.

P3. [Todo comecinho de módulo eu faço] ${ }^{30}$. Eu passo prá eles o que a gente vai estudar no módulo, o próprio portfólio do aluno já vem os temas, já vem discriminado tudo, mas [na primeira aula eu peço prá eles trazerem a idéia do que eles sabem] ${ }^{31}$. Então, agora a gente está trabalhando gases e você me propôs prá sugerir situaçõesproblema ao invés de perguntar o que é que eles acham de gases. Eu comecei a levar um monte de situações prá eles. Inclusive fiz a experiência da bexiga cheia da bexiga murcha, se o ar tem massa, se o ar não tem massa. E joguei as situações-problema prá eles resolverem. Porque precisa, porque a gente fundamenta. Porque tem coisas que inclusive eu posso pular, os alunos me trazem e eu digo, então eles já estão prontos nesse ponto então a gente pode ir prá outra parte. Não preciso trabalhar tanto análise dimensional, ou preciso dar uma ênfase na análise dimensional, nas unidades... Então isso é importantíssimo pro planejamento.

P. Você utiliza o levantamento de conteúdos prévios de alguma forma?

P3. [Utilizo] $]^{32}$.

P. Prá fazer o planejamento?

P3. Sim.

P. E se a partir dessa avaliação inicial você percebe que eles não têm alguns prérequisitos prá esse conteúdo?

P3. Então precisa parar e voltar. Precisa refazer.

P. Então como é que fica a padronização daqueles conteúdos que você colocou?

P3. Aí a gente "rebola", porque a gente tem que correr, não por uma obrigação de ter que cumprir o que foi dito. Mas a gente precisa tentar adequar, no mesmo tempo, essa retomada e caminhar, ou paralelamente, ou depois disso, caminhar com o que havia planejado. Realmente prá gente não ter esse problema de atrasar ou de não.

P. Na questão 9 você coloca que as "suas referências para o planejamento são, para o conteúdo programático, orientações de exames, livros didáticos e etc. Para metodologias e estratégias, os PCN, orientações da Secretaria da Educação e etc". Eu achei um pouco contraditório. Você poderia explicar melhor?

P3. O quê? A questão do...

P. Você já leu o PCN inteiro de Química? 
P3. Sim.

P. Então lá ele coloca uma estratégia de ensino e temas estruturadores para o ensino. Pelo que eu entendi aqui você faz uma mescla. Então será que esse trabalho não fica um pouco complicado? Como fica isso?

P3. Embora a gente tenha, como você falou esses temas orientadores, os PCN, tudo...

P. Que não exclui o conteúdo.

P3. De forma alguma. Desde que era a proposta da CENP aqui no Estado de SP, a gente tem aqueles livrinhos verdes que perseguiram a gente. Mas o PCN também não se prende só a isso. Ele se prende muito na parte prática, ele se prende nessa coisa que o aluno já traz, no conteúdo... no conteúdo não, no cotidiano do aluno. Então ele traz algumas outras estratégias que você pode adaptar também ao seu modo de trabalho. Então vamos supor assim, a gente está amarrado ao conteúdo na escola. Então foi uma orientação que a gente discutiu, a gente acabou propondo pros professores: "Vamos fechar essa questão da padronização do conteúdo". Tanto que é o primeiro ano que a gente está fazendo isso. Mas a gente pode apanhar, levar um couro até o final do ano por causa disso, e realmente pro ano que vem ter que rever. Mas esse ano a gente está testando isso prá não deixar também muito aberto, como eu falei no começo. Mas mesmo assim a gente pode se basear, como eu falei, nas orientações práticas mesmo que essa documentação traz. Até a Secretaria da Educação mesmo tem alguns documentos de práticas na sala de aula, de investigação, de incentivo ao letramento, incentivo ao monte de coisa que a gente vai lendo e vai selecionando para a nossa prática. Então foi isso que eu quis dizer que para a minha prática eu me baseio bastante em algumas observações que tem nesses documentos oficiais. Também [não levo ao pé da letra o que diz o PCN, não levo ao pé da letra o que a CENP diz] ${ }^{33}$. Eu [já estou no oitavo ano de Estado, então a gente vai criando uma prática própria, vai adaptando, tirando aquilo que não deu certo, colocando coisas novas e vendo o que vai mudando e o que vai permanecendo] ${ }^{34}$. Mas [pro conteúdo mesmo, mantém um linha a ser seguida que a gente vai trabalhando ela, conforme uma orientação ou outra] ${ }^{35}$.

P. Quando a gente foca no conteúdo programático, por isso que eu achei um pouco contraditório, a gente pensa naquela aula tradicional, onde eu preciso cumprir com esse conteúdo todo, então é aquela aula expositiva, milhares de exercícios, enfim. É super corrido porque tem que cumprir todo o conteúdo. Então a sua prática está fora desse padrão?

P3. Não digo que só a minha. A gente, quando trabalha nos blocos de aula, é uma coisa que eu sempre deixo bem claro para os professores [...] não tenham a ilusão que você vai entrar às 7 horas na sala abrindo a boca e as 22 h50 você vai fechar a boca. 
Porque você não vai agüentar, os alunos não vão agüentar. Então nesse sentido, os professores que estão no Laerte, não só nesta escola, mas em outras escolas modulares, já sabem que a prática tem que ser, pelo menos, no mínimo inovadora. Porque se não o aluno se enche e você se acaba. Então a gente já tem professores que trabalham com outras metodologias, já não tem essa cabeça de que eu vou chegar falando e sair falando, porque não acontece. Então sempre tem uma atividade diferente, sempre tem uma pesquisa, sempre tem "Vamos agora escrever..., vamos agora recitar..., agora vem aqui na frente explicar o que você entendeu", então a todo o momento a gente tem uma atividade dessa pipocando. Não necessariamente é um projeto, porque hoje tudo se fala em projeto, até brinco com os professores: "Fez, registra. Pelo menos é currículo prá você." Mas imagina, marquei um seminário com um aluno, uma coisinha..., ele trouxe uma folhinha... Eu falo: "Registra, porque é um seminário que você está subsidiando o aluno em uma série de habilidades. Então os professores daqui já não tem esse padrão de aula, tradicional. E o conteúdo, ele serve já, prá nortear suas atividades. Então, eu não vou me prender na aula tradicional, mas eu sei que esse bimestre, é esse conteúdo que eu devo trabalhar. Como eu vou trabalhar, aí já é uma peculiaridade minha. LabVirt esse bimestre. Solange, Labvirt nos bimestres dela e nas salas dela. Mas e os professores que não tem essa ferramenta? Vai fazer seminários, vai fazer uma série de outras atividades focados, embasados por esse conteúdo que a gente traçou. Então [a gente tem a cobrança da padronização sim, a gente quer que o aluno tenha condições de ter a mesma aula, o mesmo conteúdo de manhã e à noite, mas a didática de cada professor vai com eles] ${ }^{36}$.

P. E a realidade desses alunos, da comunidade, é levada em conta prá alguma coisa?

P3. À noite a gente tem. Porque de manhã é uma realidade assim... A gente diz que o nosso bairro é bem distinto. Porque a rua de cima, onde fica a escola, são casas de bom padrão, todas com carro na garagem. Atrás da escola você já vai ter duas favelas. A rua de cima aqui, é a rua limite do bairro. A gente costuma brincar que de manhã estudam os alunos dessa parte da Dutra e à noite os alunos da parte de lá. Então a gente precisa intervir mesmo nisso. Enquanto de manhã a gente tem uma clientela mais sossegada, um pessoal mais educado, um pessoal até mesmo com dinheiro, a gente não pode negar isso, a gente tem aulas mais tranqüilas, tudo. À noite, a gente, desde que eu me afastei prá coordenação, a gente sempre teve muito problema com essa galera que vem prá escola muito despropositada. Então uma das grandes preocupações nossas a noite foi levar em consideração isso que eles não trazem. Não necessariamente o que eles trazem. Mais a falta de educação a falta de apoio, falta de perspectiva de vida, e a gente baseou num projeto da secretaria de educação que tinha 
o protagonismo juvenil e esse projeto reverteu um pouco, porquê achavam que era só tirar o aluno da escola e colocar num teatro, tirar o aluno da escola e colocar num Sesc, não a gente protagonizou o nosso aluno dentro da escola, então "O que você sabe fazer? Ah eu sei fazer artesanato“. Então bota uma oficina de artesanato na aula desse moleque. "O que você sabe fazer? Ah eu gosto de ler". Então vai cuidar da biblioteca. Então à noite a gente vai articulando as ações dessa maneira. Então uma vez por bimestre a gente tem as salas abertas, então os alunos da noite, a gente pára as aulas por uma semana, e aquele grupo de alunos se apresenta para toda a escola, então tira meia aula de cada aula, já que a gente não pode tirar o dia todo porque é modulo então meia hora, quarenta e cinco minutos ou uma hora e desce aquela sala todinha assiste à palestra. Então a gente vai dessa maneira despertando no aluno um prazer maior de estar na escola e nisso a gente embute o que a gente quer, perspectiva de vida, vai fazer alguma coisa depois, não é porque seu pai é analfabeto que você vai morrer analfabeto. Então tudo isso a gente vai tentando trabalhar, isso acontece à noite com bastante freqüência, durante o dia já é uma outra clientela, já é uma clientela que vem para a escola mesmo, com gana de aprender e levar para vestibular, não é cem por cento óbvio, mas a gente tem já essa grande preocupação.

\section{P. É a maioria?}

P3. A grande maioria.

P. E você já fez um levantamento de quantas dessas pessoas entram num vestibular, em que faculdade, que universidade, pública ou privada?

P3. A gente chegou num registro, a gente todo ano registra os que se inscrevem. No ENEM a gente consegue uma inscrição de oitenta e cinco por cento dos alunos de terceiro médio, a gente tem que levar em consideração que eles tem isenção de taxa, a inscrição é feita na própria escola, então tem todo... só falta uma bandeja com chazinho.

P. E mesmo assim não é de cem por cento?

P3. Mesmo assim não é cem por cento, de oitenta a oitenta e cinco por cento de inscrição dos alunos de terceiro. Para prestar vestibular muitos deles se inscrevem, principalmente nessas faculdades daqui, tem a Interlagos aqui em cima, a Albert Einstein aqui, a Wizard lá em baixo que é um pouquinho melhor, tem a Unib que é perto, a Unip que é perto, então eles se inscrevem por aqui. Não vou estar mentindo para você se as inscrições não beirarem oitenta, oitenta e cinco por cento dos alunos da manhã.

P. E as aprovações? Fica sabendo?

P3. Eles sempre voltam para pedir declarações, "Ah eu preciso de uma declaração prá levar prá faculdade", mas se eu for colocar em porcentagem prá você, vai para trinta, vinte e cinco, trinta no máximo não passa disso. Numa sala de quarenta alunos, se eu for pensar em dez que efetivamente se matriculam numa faculdade seriam 
uns vinte e cinco por cento, aí eu vou estar chutando uma proporção mais adequada, do que eu por uma mais alta.

P. Então de quarenta alunos você acha que trinta se inscrevem pelo menos tentam o vestibular?

P3. Tentam o vestibular, desses dez efetivamente fazem a matricula, quantos que terminam eu não sei.

P. E esses alunos teriam condições de pagar uma faculdade?

P3. Muitos deles têm, da manhã têm.

P. E da noite?

P3. Da noite não.

P. E da noite quanto é a porcentagem de alunos que se inscrevem na faculdade? Que gostariam de fazer uma faculdade?

P3. Que gostariam... eles tem muito sonho, a gente sempre... como eu falei, a gente faz trabalho, a gente o ano passado chegou a ter, não foi uma feira de profissões, mas a gente teve uma série de estudos de profissão, então a gente encheu a escola de cartaz, então eles se envolveram bastante nesse trabalho, então eles sonham em fazer, mas depois não sabem como financeiramente se manter em uma faculdade, e fica aquela coisa "Ah na USP eu não passo, na USP eu não passo", porque padrão de universidade pública prá eles é a USP e eles ficam perdidos. Depois a gente fala que existem meios para conseguir bolsa, então o aluno que prestou ENEM por exemplo, quantas vagas do PROUNI ficaram sem alunos esse ano, porque ou não foram bem divulgados ou o aluno não correu atrás, então tem como fazer um curso superior de graça no Brasil hoje, então eles não tem essa visão ainda, tem muito interesse, muitos deles não se inscrevem, porque simplesmente não vai ter como pagar e acaba ficando mesmo no terceiro médio, só com a vontade de fazer, ou espera mais um ano espera dois anos.

P. A porcentagem de vontade é menor?

P3. A porcentagem de vontade é maior.

P. Do que da manhã?

P3. Ah sim.

$P$. E quantos se inscrevem também é bem menor?

P3. Bem menor, e quantos passam também, é pouquinho.

$P$. Então pensando nisso você não acha que esse planejamento prá noite poderia ser diferente do da manhã? Não embasado em conteúdo, mas em outra... Na realidade dele, em algumas coisas que poderiam ser mais úteis para ele, além do que o conteúdo?

P3. Aí a gente vai ter outro problema, vamos esquecer, por exemplo que a orientação da direção da escola esse ano foi que para a manhã e a noite falasse a mesma linguagem. 
P. Não, fala como professor, o que você acha como professor?

P3. Enquanto isso eu tô te falando, porque se eu ministrasse aula à noite ou de manhã, eu seria cobrado nos terceiros anos de trabalhar as mesmas coisas nos dois períodos.

P. Mais considerando que para elaborar um planejamento você pensa na realidade da clientela, e você me disse que são duas clientelas totalmente diferentes, como é que fica então essa historia de padronizar o conteúdo, se as duas clientelas são totalmente diferentes?

P3. Primeiro assim conteúdo no termo de norteador não necessariamente prático, não necessariamente atividades, mas eu entendi a sua pergunta no sentido que não é tão significativo pro meu aluno da noite estudar teoria cinética dos gases, como está sendo significativo pro meu aluno da manhã estudar teoria cinética dos gases, uma vez que de manhã eles vão usar isso prá alguma coisa, até mesmo como no Labvirt, então é isso é um pouco mais significativo para eles. Mas se a gente for pensar em instrumentalizar esse aluno prá alguma outra área, então vamos esquecer, de manhã a gente fecha visando exatamente o uso de aula prá fazer um bom vestibular, uma boa prova, seguir carreira. E à noite a gente segue a risca o que as diretrizes novas nos dizem, subsidiar o aluno autônomo para o mercado de trabalho.

P. Não tão voltado para o mercado de trabalho, eles já não estão mais tão assim profissionalizantes, já saíram um pouco.

P3. Mas então é nesse sentido que a gente pergunta "Que estrutura a gente tem prá isso?", se eu fosse atender a realidade do meu aluno da noite, sendo bem cruel e materialista, o meu aluno da noite ele chega com fome na escola e o governo não põe uma merendeira à noite, há quantos anos a gente tá pedindo uma oficial de merenda.

P. Eles não comem antes de entrar?

P3. Tem a cantina, mas a cozinha da escola à noite não funciona, porque não tem funcionário mesmo, pessoal prá estar fazendo isso, porque se a gente tivesse funcionário a gente até poderia abrir, porque o governo mandaria verba da merenda para o período da noite também, mas a gente manda e-mail, manda oficio prá diretoria pedindo remanejamento de funcionário, pedindo prá ter esse pessoal na escola. Então o aluno da noite chega com fome, muitos deles moram aqui na vinte aqui em cima, deles não almoçam, então eles até aproveitam às vezes depois do intervalo da tarde que termina umas quatro horas quatro e pouquinho, tem uns dez quinze alunos que vem para a escola almoçar, da noite, a gente não alarma, eles entram pelo portão dos alunos quietinho vão pro refeitório comem a merenda depois vão embora e voltam só à noite. Então se a gente for pensar na realidade desse aluno, esse aluno precisaria de higiene, 
comida, carinho, tudo isso que ele não tem em casa, além de uma perspectiva melhor de vida, uma profissionalização.

P. De um entendimento melhor da realidade dele?

P3. É ele precisaria de isso mesmo, precisaria ter uma oficina, nem que fosse para ensinar o aluno a lixar um cabinho prá chaleira, um cabo de vassoura.

$P$. Eu não diria uma oficina, eu acho que não precisa a esse ponto de chegar a uma coisa muito prática, mas, por exemplo, o que ele vai fazer com a teoria cinética?

P3. Quase nada.

P. Prá realidade dele?

P3. Ele vai encerrar o módulo, vai se esforçar prá tirar um diploma.

P. Na realidade se eu não tivesse feito Química eu hoje também não usaria para nada. Então assim eu até entendo que de manhã os alunos tenham essa vontade de vestibular e infelizmente o vestibular "dita" hoje o que é para ser dado no ensino médio, então ele tem um objetivo com aquele conteúdo todo, mas aí no noturno [...]

P3. Eu entendo que a gente precisa mesmo rever, mas muitas vezes a gente na escola é meio isolado para muita coisa, a gente consegue muita parceria e muito fácil, mas quando essas empresas ganham alguma coisa em troca, então agora a gente está com o projeto "Escola da família", então a empresa precisa fazer parceria com o governo, fazer uma oficina para os pais no final de semana, daí tem uma série de coisas que o governo pode oferecer para esta empresa. Mas quando você fala, por exemplo, a Unet que é parceira nossa no final de semana, ela é uma escola de informática ali em cima, para a Unet vir fazer uma semana de seminário para os alunos sobre o que é trabalhar com tele marketing, sobre o que é trabalhar com digitação de textos, enfim qualquer coisa simples que o aluno possa se empolgar um pouco mais, ela não vem durante a semana. Já vieram, já ofereceram para a escola máquinas novas se a gente conseguisse cem alunos novos para a escola deles, então isso é muito fácil, mas o que a gente efetivamente precisa às vezes a gente fica muito isolado, só contando com a boa vontade dos professores para estarem trabalhando, muitos dos meus professores, param no meio da aula para despertar a atenção de aluno, assim "tá bom vamos ver o que vocês realmente precisam" às vezes o aluno só precisa parar e conversar, aconteceu alguma coisa no ano passado que apareceu um justiceiro para eliminar gente, esse justiceiro estava "apagando" todo mundo, inclusive dois pais de alunos nossos foram assassinados, e foi um dia em que a gente teve que parar a aula à noite dez e meia a minha diretora já tinha dispensado todo mundo para a própria segurança deles, então a gente dispensou sala por sala bem devagarzinho para eles poderem ir sem fazer alarde na rua, e um monte de professores falaram aquele que não conseguiam dar aula aquele dia, porque eles queriam expor o medo de estar sete horas num lugar fechado, com um 
justiceiro do lado de fora, porque a escola é muito pacata, então aquele tão exemplo, então às vezes é necessário a intervenção de fora, então o planejamento fica completamente de lado.

P. Você coloca aqui prá mim que você planeja conteúdo geral como principio norteador, cada módulo e série separadamente, mais especificamente personalizado para a classe. Você faz um registro disso? Você tem?

P3. Sim eu registro. Eu tenho aquele do Labvirt.

P. Só?

P3. Sim, de aula-aula só.

P. Você só dá aula para os terceiros anos? Esse ano?

P3. Só com os terceiros de manhã.

P. Para esse começo de ano você já começou com o Labvirt?

P3. Isso. Já comecei com a teoria cinética dos gases.

$P$. E os outros. E quando esse módulo acabar?

P3. Bem como no ano passado eu trabalhei com o Labvirt bem esporádico, eu testei numa sala, testei em outra só para pegar prática mesmo sabe. Esse ano meu intuito é já trabalhar com todas as turmas durante os bimestres, que depois, agora eu vou entrar em química orgânica que dá pano prá manga para você trabalhar uma série de outros conteúdos nas simulações, eu pretendo planejar em cima da proposta do Labvirt mas eu terminei duas classes antes do nosso encontro, no nosso primeiro encontro eu já tinha passado por duas classes, para organização minha eu já tinha registrado numa folha à parte, não digitei bonitinho tal, mas eu parei antes de começar essas aulas e falei "bom eu vou ter dez dias com eles, o que eu vou fazer nesses dez dias?" Então eu registrei em cima ainda da Lei, com os exercícios todos, peguei livro peguei material e fui ticando o que eu ia passar aula a aula, [então para organização minha] ${ }^{37}$, [para eu poder depois, no terceiro "b" e terceiro "d" ter nessas duas salas depois a mesma seqüência de

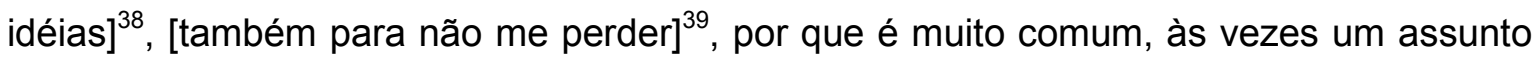
puxa outro e você acaba fugindo, então para me organizar melhor eu fiz esse registro para as salas em que eu não trabalhei o LabVirt.

P. E aí para o próximo módulo, a hora que acabar teoria cinética, você vai planejar o próximo módulo e usar o Labvirt de novo?

P3. Isso, planejar para trabalhar nesse bimestre de terceiro e de segundo com o comecinho da química orgânica, depois eu vou ter as funções, aí eu vou ver direitinho se o Labvirt vale a pena encaixar no bimestre de funções, porque o quarto bimestre nós estamos pensando, pelo menos eu e a Carmem, de estar passando uma revisão um pouco corrida dessas dez aulas para os alunos da manhã, uma revisão de terceiros, eu 
tenho quatro ela tem mais um, então nós estamos vendo essa possibilidade de pelo menos esses três bimestres com o Labvirt.

P. Como está sendo ter que planejar as aulas do Labvirt? Você acha que é necessário? Se não fosse pedido lá na Escola do Futuro, que se entregasse isso, que não tivesse esse acompanhamento, você faria isso?

P3. Não digo que eu faria, mas que eu teria que fazer. Porque é muito complicado você não ter isso prá se organizar. Que quando você trabalha com o Labvirt você trabalha tudo muito rápido. Não porque você tem menos aula prá trabalhar o seu conteúdo mas no projeto Labvirt mesmo, quando você planeja você tem a reunião do grupo aqui na aula você..., passa voando que você não percebe. Você atende um grupo aqui, atende um grupo ali. [Você precisa ter pelo menos, não um documento formal, que é o que eles pedem prá gente lá na Escola do Futuro, mas você precisaria ter pelo menos uns tópicos, essa aula é isso, essa aula é aquilo, prá gente poder se organizar na aula] $]^{40}$. [Planejar o LabVirt dá muito trabalho $]^{41}$. Eu sentei com o Alexandre lá. Ele falou: - Faz um esqueminha, depois desse esqueminha você pensa nele, aumenta ele um pouquinho, depois você detalha mais, detalha mais...e ontem pelo telefone ele falou: - Eu li o seu planejamento... e eu falei: - Não, a Marcela inclusive mandou uma série de orientações prá mim estar incluindo, tá analisando... , e ele falou: - Mas mesmo assim quando você tiver na aula, aproveita um espacinho e anota o que aconteceu que você não previu, que quanto mais detalhado esse planejamento ficar é melhor, inclusive para compartilhar com outro professor, ou para mandar lá para a USP, então é uma coisa que a gente não tem essa dimensão que isso ganha, e esse planejamento ganhou uma dimensão muito grande, porque daqui a pouco vai estar assim: Aqui eu respiro três vezes.... o nível de detalhe é muito grande.

$P$. Mas você acha que isso é bom ou só atrapalha?

P3. [É muito bom] ${ }^{42}$, não atrapalha porque é muito bom porque [a gente prevê melhor nossa prática, nossa ação na sala de aula, a gente evita as saias justas $]^{43}$, vamos dizer assim, por que, por exemplo, por mais que você pense por mais que tudo já aconteceu..., como eu falei segunda feira eu planejei um levantamento de idéias previas, planejei o estudo dos três estados da matéria, os aspectos macros e microscópicos aquela coisa toda, de repente... deu dez minutos, quinze minutos de aula ainda. Vou fazer o que nesses quinze minutos? Eu falei: - Galera assim não dá, vocês vem vocês sabem o que eu vou dar prá vocês... Porque eles têm o portfólio do que eu vou dar no dia, - então prá não atravancar eu vou dar quinze minutos de brinde prá vocês... então já é uma coisa que tem que rever, que são esses detalhezinhos que vão acontecendo, que se a gente não prevê...aí o desespero acaba sendo maior. Então nesse ponto [o planejar, embora dê trabalho, eu acho que ele é muito útil] ${ }^{44}$. 
P. Você fazia isso antes do Labvirt?

P3. Não. Esse planejamento de 2004 que eu te mandei por e-mail ele já era completão, então muitas vezes assim eu chegava no começo do módulo, eu pegava: - Ah então eu vou trabalhar com, vamos pegar o primeiro tema de $1^{\circ}$ ano, propriedades da matéria, alguma coisa assim, não é?

P. História e propriedades da matéria e estrutura atômica.

P3. [lsso] ${ }^{45}$. Daí eu no meu material didático antes do módulo, dava uma lida em todos os capítulos, selecionava os exercícios, fazia as bolinhas no livro didático, e ia deixando o barco fluir. Começava a minha aula como se as 20 aulas fossem seqüenciais, né. Daí você lê tudo, pega todos os exercícios e aí depois só dá uma pausa, sem se preocupar com a seqüência, sem se preocupar com: - A não aqui a minha aula acaba realmente. Então eu tenho que planejar prá duas não tenho que planejar prá 20...Não tinha a preocupação da minha aula ter uma estrutura mais lógica, uma seqüenciação. Então, isso foi no Labvirt que eu falei: - Não, já que tem que planejar então vamos fazer decente. $\mathrm{E}$ a gente aprende que é necessário. Embora, desde a Licenciatura a gente viu planejamento, aquela coisa toda a gente só aprende quando apanha.

P. Você viu planejamento na Licenciatura? Você praticou, você discutiu o planejamento?

P3. Eu tinha 4 aulas de prática todo sábado e a gente tava logo depois de um concurso, o concurso foi em 99. Nossa turma entrou em 2000 e a gente teve muita ênfase no PCN. Então a gente teve com a $M^{a}$ Fernanda muito PCN e GEPEQ. Então, a gente estudou bastante isso. [A questão do planejamento não foi tão superficial não] ${ }^{46}$. [A gente estudou muita coisa sobre planejamento] ${ }^{47}$, porque a gente estava em cima da proposta do GEPEQ. Então, toda aquela questão de primeiro experimentar, depois traçar modelos e depois você vai (...) modelos prá depois construir conceitos. Toda a metodologia do GEPEQ. Então nesse ponto a gente viu o planejamento. [Mas prática de planejamento, não] ${ }^{48}$. A gente teve algumas diretrizes de elaboração de aula, por exemplo, como trabalhar uma aula de laboratório em 50 minutos, que era a realidade da maioria. Então como fazer uma experiência em 10 segundos. Então a gente tinha que planejar, a gente tinha que elaborar uma proposta de uma experiência que coubesse naquela aula. Ou como fazer o levantamento de idéias prévias sem ocupar dois bimestres. A $\mathrm{M}^{\mathrm{a}}$ Fernanda sempre mandava estas questões prá gente e isso a gente tinha que devolver prá ela por escrito. Era um planejamentozinho, mas nada assim, como a gente viu nessa proposta do Labvirt de pensar em um trabalho mais longo, de pensar numa série de fatores. A gente sempre pensava isoladamente. Então foi essa a experiência que eu tive de planejamento na faculdade. Tanto que nas aulas práticas, eu me embasava nisso, né. Então quando eu vou para os laboratórios com os alunos eu 
sempre tenho uma metodologia já própria do laboratório e isso eu vi na licenciatura, [mas assim aula-aula, o que é necessário e tudo foi na prática mesmo na escola] ${ }^{49}$, que [a coordenadora trazia aquela folhinha, que o pessoal brinca: preencha com objetivos, com metodologias e tal, e foi assim que eu aprendi a fazer planejamento] ${ }^{50}$.

P. Para os seus alunos você adota livro?

P3. Não, é tudo na lousa e na garganta.

P. Nem apostila?

P3. Não.

P. Só esclarecendo, quando você coloca que avaliação deve ser continua, são esses tipos de avaliação diagnóstica que você fala?

P3. Isso.

P. Você coloca como objetivos gerais e até nos objetivos específicos, muito aqui as palavras que a gente vê no PCN ...

P3. Subsidiar, propiciar...

$P$. Isso, porém você fala em ênfase no conteúdo e tal, você acha que com essa ênfase que você dá você conseguia alcançar esses objetivos que você coloca? Tudo você aborda desses conteúdos que você coloca?

P3. Claro que não tudo ao mesmo tempo, mas a gente tendo bem clara essa questão de que eu tenho o meu norteador, que é o meu conteúdo programático, e você vai fazer as atividades em cima disso, você pode perfeitamente obter essas habilidades, os conteúdos dependendo da forma como você conduz sua aula. Eu não vou quadratizar a minha aula, né, porque senão eu vou estar podando o meu aluno mesmo, então dependendo do tema da aula, dependendo do tema do módulo você consegue resolver uma atividade, que por exemplo ele possa relacionar isso que ele está descobrindo agora com o que ele viu em física com o que viu em biologia, então você tem que dar essa oportunidade para o aluno, não que a ênfase no conteúdo te proíba isso, eu acho que o planejamento em uma aula bem conduzida, porque eu não sou o expert na sala de aula, mas se você conduz direitinho o seu planejamento, você consegue subsidiar o seu aluno com uma série de coisas e aí claro se você for pensar em aula tradicional esquece mesmo, porque não tem como você alcançar isso aí nunca.

P. Tem algum conteúdo de Química que você exclui do seu planejamento?

P3. Por gostar ou não gostar? Ou por achar que não é...

$P$. Depois você vai me dizer por que.

P3. Ah, entendi, porque nesse ainda consta radioatividade né. E nesse ano na discussão, acho que tá no terceiro ou no segundo ano... então foi no ano anterior que eu tirei com a Rosa e depois esse ano a Carmem pediu prá eu voltar, foi uma coisa assim. Eu sei que radioatividade [é um conteúdo que eu no meu ver não tenho muito prazer de 
trabalhar com o aluno não] ${ }^{51}$, [não que não seja importante] ${ }^{52}$, mas pensar em falar pro aluno que do átomo sai o alfa e depois o nu e tal... existem formas de abordar radioatividade mais legais, eu acho que você pode trabalhar bomba atômica, trabalhar fissão, fusão nuclear que prá eles é mais interessante do que ficar fazendo cálculo de partícula que entra, partícula que sai, então [é um conteúdo que eu deixaria de lado por opção própria] ${ }^{53}$, né $\mathrm{P} 3$ com a radioatividade, e esse ano voltou pro planejamento, lá nos conteúdos está no finalzinho do segundo ano. 


\section{ENTREVISTA COM P4 (05 DE AGOSTO DE 2005)}

P. O que é o planejamento de ensino e prá quê que ele serve?

P4. Ele [facilita o processo que vai ser aplicado] ${ }^{1}$ com os alunos, mas conforme ele vai sendo aplicado, conforme vão sendo dadas as aulas, eu vou vendo as dificuldades e o planejamento, às vezes, é quebrado. Se eu vejo que os alunos têm mais dificuldade em cálculo eu volto e revejo cálculo matemático com os alunos.

P. Você elabora um planejamento a cada ano ou você utiliza os dos anos anteriores?

P4. [Conforme eu vou vendo as dificuldades dos alunos eu vou apenas modificando algumas coisas. $]^{2}$

$P$. Tá você já pega o do ano passado...

P4. E vejo aquilo que tá tendo dificuldade e modifico um pouco.

$P$. Você acha que é importante planejar as suas aulas?

P4. [É lógico.] $]^{3}$

P. Por quê?

P4. [Isso facilita. $]^{4}$ [Eu não chego boiando na sala de aula. $]^{5}$

P. Você chega...

P3. [Sabendo o que eu vou falar.] ${ }^{6}$ Por exemplo, quando tem algum assunto que faz tempo que eu não vejo, como a Química é muito grande, muito ampla, a gente esquece.

P. Quando você elabora o seu planejamento, o que você acha que é importante ter nesse planejamento? O que precisa constar lá?

P4. Na verdade [tudo é importante] ${ }^{7}$, né. Apesar do Estado falar que não existe mais conteúdo, o [vestibular é conteúdo, é conteudista] ${ }^{8}$, então tudo é importante. Até aquele comecinho de separação de misturas pode cair numa questão. Então se eu falar que não é, que não cai, acho que tudo é importante. Não tem como...

P. Mas eu digo assim, igual aqui no seu planejamento, você tem lá, os objetivos, os conteúdos...Num planejamento completo, o que deve constar?

P4. [O máximo que der prá dar pros alunos. $]^{9}$

P. Em relação aos conteúdos de Química?

P4. Isso.

P. Para a seleção desses conteúdos de Química quais são suas referências? Em que é que você se referencia prá selecionar tais conteúdos? Então, você citou assim "eu sigo uma seqüência lógica". Que seqüência lógica é essa? Como você seleciona esses conteúdos? 
P4. Ah, uma [seqüência lógica que eu adquiri já esses anos dando aula.] $]^{10}$ [De livros] $^{11}$, ver uma [seqüência que é fácil ser dada para os alunos] ${ }^{12}$, né. Essa seqüência...Eu não vou começar falando de ácidos se eu não falei do comecinho...O que é um número atômico, o que é um próton, de onde veio. Eu tenho que começar do começo até chegar num...

P. Então, e essa linha de onde você se baseou, prá chegar nessa linha que tem que ser o átomo primeiro e depois o ácido?

P4. Em livros.

P. Nos livros didáticos?

P4. [Nos livros didáticos $]^{13}$ e por vivência, né. Depois de alguns anos dando aula você vê que...

$P$. Que tem que ser essa seqüência?

P4. Não é que tem que ser, [se torna mais fácil prá mim.] $]^{14}$

P. No seu planejamento, por exemplo, não consta o ensino da termoquímica. Como você faz essa escolha por um conteúdo ou não no seu planejamento?

P4. Essa parte de termofísica, termoquímica...

P. De termoquímica. Por exemplo, ...

P4. Pilhas...

P. Não consta lá termoquímica. Eu queria saber por que você não colocou termoquímica no seu conteúdo, na sua seleção de conteúdos, por exemplo, e você coloca radioatividade. Então assim, você, de uma certa forma excluiu um. Como é que você faz essa exclusão de um assunto e não de outro? Por que radioatividade e não termoquímica?

P4. Vejo que os dois são importantes. Mas vejo que é mais fácil, e eu [tenho também mais facilidade prá explicar] ${ }^{15}$ radioatividade. Termoquímica eu tenho dificuldade. (O professor falou também: Não vai publicar isso!)

P. E pro aluno?

P4. [Eu acho que ele também tem. $]^{16}$

P. Dificuldade?

P4. Entra balanceamento, termopilha, termofísica, termoquímica.

P.Você diz aqui no questionário que você modifica o conteúdo conforme a sala. Então existe um planejamento prá cada turma?

P4. Tem. Pro $1^{\circ}$ ano, pro $2^{\circ}$ ano e pro $3^{\circ}$ ano. As salas?

$\mathrm{P}$. Entre salas. Então assim, entre o $1^{\circ} \mathrm{A}$ e $\circ 1^{\circ} \mathrm{B}$. O conteúdo é o mesmo?

P4. [É o mesmo.] ${ }^{17}$ Só que de vez em [quando você vê que eles estão com uma dificuldade num assunto, você fica mais um pouco no assunto] ${ }^{18}$ aí [atrasa o processo todo.] ${ }^{19}$ 
P. Entendi. Então o planejamento inicial é igual pros dois. Só que no momento da aula, talvez você precise modificar porque uma sala caminha diferente da outra?

P4. Eu já percebi assim, eu dou aula pro supletivo também, né. Às vezes você entra numa questão de concentração, aí à noite não dá prá dar muita coisa. Uma só às vezes. Aí entra a parte de fazer cálculo. É um Deus nos acuda a dificuldade de fazer o cálculo. Eles tentarem lembrar que multiplicando um número decimal, como que multiplica. E eu faço a conta e mostro. Então, é uma questão que você perde muito tempo. Aí o que acontece? Atrasa o planejamento. [Não que eu queira ser diferente uma sala com outra. $]^{20}$

P. Em que momento é feita a avaliação diagnóstica? Você leva em consideração o resultado dessa avaliação no seu planejamento?

P4. Eu explico matéria, dou exemplo e na aula seguinte eu dou exercício. Aí eu [vejo quem está participando quem não está...] ${ }^{21}$ Porque eu anoto tudo no diário, tudo que eu faço é tudo anotado lá na página 10 do diário. Quem está participando, quem não está. [Aí eu vejo quem está com dificuldade ou não.] ${ }^{22}$ Eu [vejo também quem não faz nada.] ${ }^{23}$ Essas pessoas eu falo: - $E$ aí, vai fazer ou não vai? Só que não é que nem...Talvez alguns professores tenham essa facilidade de desse diagnóstico e fala se 0 aluno é semi-analfabeto e vai se aprofundar mais. [O meu diagnóstico é mais na forma de participação. $]^{24}$

P. E aí você fala aqui que você modifica o planejamento dependendo da necessidade. Como é que você faz então? Você faz essa avaliação diagnóstica e como é que você modifica esse planejamento?

P4. Aquilo que eu falei. Se eu vejo que uma sala, no exemplo lá das soluções da concentração, tá penando, aí eu tenho que modificar. Dar mais exercício e dar menos o que eu ia dar mais prá frente. Quer dizer, o planejamento não seguiu até o fim. Eu modifiquei um pouco meu planejamento.

P. Você tem o seu planejamento ao longo do ano? Você consulta o seu planejamento ao longo do ano?

P4. [Consulto.] ${ }^{25} \mathrm{Eu}$ [vejo qual a seqüência, mais ou menos, que eu estou.] ${ }^{26}$ Dependendo da sala eu esqueço às vezes qual que é, aí [eu olho prá ver o que é que eu tenho que dar. $]^{27} \mathrm{E}$ o pessoal olha, tanto é que depois dá o visto no meio do ano. A coordenadora mesmo olhou, viu se aquilo que está no meu planejamento tá batendo ou não. Se aquilo que eu falei que iria fazer como avaliação tá indo, se eu estou fazendo ou não.

P. Você quando vai fazer esse planejamento inicial do ano, você leva em consideração a clientela que você tem? Você primeiro vai ver como é que esses alunos 
vêm, né, acerca de alguns conhecimentos, ou não? Você planeja e o que você planejou você vai à sala e dá?

P4. É eu vejo que [nesses tempos está tendo um padrão de dificuldade] ${ }^{28}$, [um padrão de conhecimento.] ${ }^{29}$ [Não tá mudando muito.] ${ }^{30}$ Então, como eu falei, eu [vou mudar conforme a necessidade. $]^{31}$ Ainda mais no supletivo, eu sei o que é que dá prá dar. Eu tenho pegado supletivo já faz 4 anos. Então não dá prá mudar muito. É...Não dá prá eu chegar no supletivo, entrar com balanceamento, entrar com uma coisa também muito difícil se eles não...Se um ou dois talvez possam fazer uma coisa mais difícil, se os outros 50 não vão acompanhar. Então eu entro lá no supletivo no comecinho de tudo. Como eu entro de manhã, comecinho de tudo.

P. Mas aqui no supletivo você diminui bem a quantidade de conteúdos, né, porque as aulas são reduzidas. Então, como é que você seleciona os conteúdos que você vai dar pro supletivo, por exemplo? Então assim, a gente vê que diminuiu muito.

P4. Pelo princípio da Química. Pelo comecinho de tudo ali. Sem, como eu falei, [por falta de tempo] $]^{32}$ não dá prá eu chegar num ácido, numa base, num dá prá eu chegar numa coisa mais profunda. Mas dá prá dar bastante coisa prá eles.

P. Qual é a sua concepção de ensino?

P4. Como assim?

P. O que você entende por ensino? Você ensina para quê?

P4. [Conhecimento] ${ }^{33}$ e em certo momento [preparar pro vestibular.] ${ }^{34} \mathrm{O}$ que mais tem consciência é o $3^{\circ}$ ano da manhã. E não são todos os alunos. Então eu chego e falo: - Esta é uma questão de vestibular. E que eu pego de livros e eu mostro - Tá vendo, tem um baita texto. A pergunta tá bem no finzinho, uma pergunta bem simples. E dou um tempo prá eles tentarem fazer. Aí depois eu vou lá e mostro. Aí eles: - Ah é isso! Aí eu falo: - Tá vendo, isso eu to dando prá vocês. Tem um texto, uma pergunta pequenininha e uma resposta de uma linha.

P. Então, concluindo. Você ensina para preparar pro vestibular? As três séries?

P4. Vamos dizer, o que tem consciência é o $3^{\circ}$ ano. Eu ensino prá [passar o conhecimento. $]^{35}$ Prá todas as salas, mas o que tem mais consciência é o $3^{\circ}$ ano.

$P$. Você faz um planejamento de cada aula antes de você entrar em sala de aula?

P4. [Não.] ${ }^{36}$ [É o planejamento que foi feito no começo do ano] ${ }^{37}$, né. Aí [se tem um assunto que faz tempo que eu não vejo, eu dou uma olhada nos livros] ${ }^{38}$ prá num...

P. Mas então como você sabe o que você vai dar hoje? A hora que você vai entrar hoje na sala como que sabe o que você vai dar aquele dia?

P4. [Eu sei o que eu dei ontem. $]^{39}$ 
P. Tá mas você teve que começar uma aula. Como foi a sua primeira aula? Você planejou o que você ia dar na primeira aula? Você fez um planejamento, um registro do que você ia fazer naquela primeira aula?

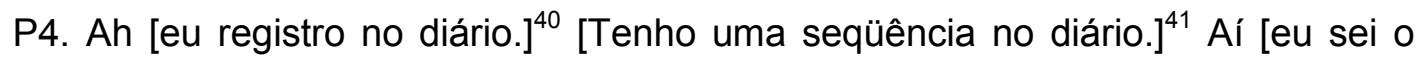
que eu vou falar. $]^{42}$

P. Aí, por exemplo. Como você seleciona os exercícios que você vai dar, essas coisas assim?

P4. [Alguns eu bolo, muitos eu pego de livro.] ${ }^{43}$

P. Você coloca aqui que seria importante ter contato com outros colegas prá planejar. Que colegas seriam esses? Só da disciplina ou da área ou geral da escola? E por que que é importante ter esse contato com esses colegas?

P4. [Troca de idéias. $]^{44}$ Mas tem que ser [colegas de Química] ${ }^{45}$, né. Ultimamente, aqui 90 e poucos por cento das aulas de Química são minhas. A noite toda sou eu. De manhã tem uma colega que vem só de $6^{a}$, a gente mal se vê. Ela chega, eu chego. Ela vai prá aula, no intervalo eu vou embora e a da tarde eu nem conheço. De repente trocar idéias: -Olha, fiz um experimento tal. Eu fiz um negócio bacana, tal. Trocar idéias.

P. E na hora então do planejamento você fez sozinho?

P4. [Fiz.] ${ }^{46}$

P. Como está sendo, ou como foi prá você ter que planejar as aulas do Labvirt? Porque ali você teve que planejar aula a aula, né. O que você ia fazer na aula 1 , o que você ia fazer na aula 2 , o que você ia fazer na aula 3, já deixar pronto doze aulas. Como é que foi fazer esse planejamento?

P4. É [não é fácil não] ${ }^{47}$, [porque foi a primeira vez ${ }^{48}$, né. [Nunca tinha feito esse tipo de trabalho. $]^{49} \mathrm{E}$ como os alunos também não estão tendo um retorno, eles estão com dificuldade do retorno, e também [a gente tem dificuldade de fazer uma coisa nova. $]^{50}$

P. Você acha que é necessário fazer esse planejamento aula a aula, ou não seria necessário?

P4. [Ajuda. $]^{51}$

$P$. Por que é que ajuda?

P4. É que nem o planejamento da aula de Química, se eu sei o que eu vou dar eu tenho uma seqüência. Mas na aula de Química, eu que estou comandando. Depende só de mim. [No Labvirt não. Tem que ter o retorno.] ${ }^{52}$ [Se eu não tenho o retorno eu não tenho como fazer a seqüência. $]^{53}$

P. Você elabora o seu planejamento anual por necessidade ou prá atender solicitações burocráticas da escola, por exemplo? 
P4. Olha [foi no começo burocrático.] ${ }^{54}$ Honestamente burocrático. Mas a gente acaba, depois que foi a parte burocrática, [você acaba usando.] ${ }^{55}$ [Acaba auxiliando.] $]^{56}$

P. Bom, no começo lá, se não tivesse não faria falta? Você chegaria e daria aula do mesmo jeito?

P4. Como eu falei, acaba auxiliando. Talvez não tivesse esse instrumento para auxiliar.

P. Durante a sua formação acadêmica você ouviu falar, aprendeu, discutiu alguma coisa sobre planejamento, como planejar?

P4. [Não.] ${ }^{57}$ Por que eu fiz um curso de Química industrial. Aí depois só que eu fiz a Resolução 2 prá dar aula. [Na Resolução 2, teve como planejar ali] ${ }^{58}$, mas na faculdade mesmo não. 


\section{ENTREVISTA COM P5 (04 DE AGOSTO DE 2005)}

P. Você elabora seu planejamento por necessidade ou prá cumprir normas burocráticas?

P5. Os dois.

P. Os dois?

P5. Os dois... É faz parte. [A gente já tem esse hábito de fazer o planejamento] ${ }^{1} \mathrm{e}$ da [necessidade por que sem ele não tem como você direcionar o que você vai trabalhar. $]^{2}$

P. E isso foi assim desde quando você começou a ser professora?

P5. Não. [No começo era...Seguia, às vezes, já copiava o que era do ano anterior então a gente só reproduzia né, seguia o livro mesmo...Assim, os padrões.] $]^{3}$ Aí eu comecei a participar de cursos e eu comecei a participar do GEPEQ, do Pró-Ciência, eu fiz três anos de Pró-Ciência e [foi aí que eu comecei a modificar o meu trabalho em sala de aula. $]^{4}$

P. Você consulta, então, o seu planejamento ao longo do ano?

P5. [Sim. $]^{5}$

P. Está sempre com você?

P5. [Sempre. $]^{6}$

P. Não entrega prá secretaria e esquece?

P5. Não, [estou sempre acompanhando.] ${ }^{7}$

P. Você acha importante discutir com os outros professores da mesma disciplina ou área prá planejar?

P5. [Sim. $]^{8}$

P. E o seu planejamento hoje é feito dessa forma?

P5. É por área. [Hoje é por área.] $]^{9}$ Antes se falava em trabalhar por área, porém [a gente não tinha essa oportunidade de se encontrar, de planejar.] ${ }^{10}$ Aí normalmente [um fazia e os outros seguiam] ${ }^{11}$, né. E pelo menos na escola que eu trabalho hoje, [no meio do $\mathrm{ano}^{12}$ teve o [replanejamento por área.] ${ }^{13}$ Então [a área definiu um projeto, um tema. $]^{14}$ Então a gente...

P. Por área assim... Então você foi com física, química, biologia e matemática?

P5. Isso.

P. E aí depois prá você fazer o seu de Química?

P5. Não tem...Porque eu já tinha...

P. Você tem algum colega de Química que faz com você?

P5. Tenho.

P. Ou você faz sozinha o seu de Química e ele faz o dele para as salas dele? 
P5. [Não, é o mesmo. ${ }^{15}$ [A gente senta junto, planeja.] ${ }^{16}$ Tanto é que quando a gente se encontra no corredor é assim: - Ah, onde é que você está? Ah eu achei um texto novo...eu achei...e dá seqüência.

P. Então tem uma colaboração. E na hora de fechar o assunto isso é tranqüilo, fechar o que vai ser tratado?

P5. [Sim.] ${ }^{17}$ Tanto é que lá [a gente tem um provão né, que é uma avaliação diagnóstica] ${ }^{18}$ e [a gente consegue dar a mesma prova prá todas as salas] ${ }^{19}$ mesmo com professores diferentes.

P. No momento do replanejamento, que você disse que vocês fizeram, as mudanças que foram propostas foram registradas?

P5. [Sim. $]^{20}$

P. E qual foi...Em quê que você se baseou prá fazer essas mudanças? Por que que houve essas mudanças?

P5. Primeiro que todo ano eles reclamavam né, vindo da direção, que tinha que ser feito um planejamento por área, que tinha que ser desenvolvido projeto. $\mathrm{E}$ como eu estava aprendendo a trabalhar diferenciado então eu acabei fazendo uma troca, né. Então ajudando os professores, quem já tinha alguma informação foi complementando e a gente foi mudando. Lentamente, né...Até hoje assim, é lenta essa mudança, mas a gente está fazendo diferente.

P. Está conseguindo. Então, mas eu queria saber assim: houve o replanejamento, então alguma coisa no replanejamento agora no meio do ano mudou?

P5. Sim.

$P$. E o que é que vocês consideraram prá fazer essas mudanças?

P5. A exigência da área. Porque no começo do ano, falou-se em trabalhar por área, só que não foi dado um momento prá gente sentar por área. Nós sentamos por disciplina e depois foi cobrada uma prova por área. Sendo que a gente não estava trabalhando a mesma coisa. Então agora, nesse momento, a gente refez no replanejamento a área. Então nós definimos. Tanto é que na série, $3^{\circ}$, vai ser o tema Prevenção Também se Ensina. Então dentro disso, Química vai trabalhar Tabagismo. Então todos vão trabalhar aquilo que já ia ser trabalhado, mas com o foco em prevenção.

P. Então este planejamento está registrado?

P5. Sim.

P. Dentro de cada tema são desenvolvidos conteúdos de Química, por que eu vi que o seu planejamento é por tema né. Como você seleciona estes conteúdos? E porque você seleciona uns e não outros?

P5. Olha, primeiro porque [a gente sabe que não tem como dar todos os conteúdos.] $]^{21}$ Eu acho que... 
P. Por quê?

P5. Primeiro que [o aluno não vai assimilar, não tem como.] ${ }^{22}$ Só se fosse uma escola particular mesmo que segue a apostila, fora isso não dá. [O número de aulas é limitado] $^{23}$, [o número de alunos é excessivo] ${ }^{24}$, então são vários problemas. Então [a gente seleciona aqueles conteúdos que a gente acha mais importante] ${ }^{25}$ e [que vai ser cobrado mais do aluno. $]^{26}$

P. Mais importante para...

P5. [Para o aluno entender a realidade dele.] ${ }^{27}$ [Aquilo que é mais próximo.] ${ }^{28} \mathrm{E}$ também [aquilo que faz parte do que seria o conteúdo da série] ${ }^{29}$, né. [A gente não foge assim tanto do conteúdo da série. $]^{30}$

P. E esse conteúdo da série, você tem referência...Quais são suas referências prá planejar?

P5. [É o tradicional mesmo.] ${ }^{31}$ [Nos livros tradicionais.] $]^{32}$

P. Então essa seriação de conteúdos você se baseia em cima dos livros didáticos, é isso?

P5. Sim. Ela continua.

P. É feito um planejamento para cada turma?

P5. [Não.] $]^{33}$

P. O planejamento é terceiros anos, segundos anos, primeiros anos?

P5. [É.] $]^{34}$ [Algumas exceções nas salas em que não consegue trabalhar, aí o trabalho é diferenciado.] $]^{35}$

P. Como é utilizada essa sua avaliação diagnóstica, que você disse que você faz no planejamento? Em que momento ela é feita?

P5. [Quase no final do bimestre.] $]^{36}$ Um mês e meio depois a gente faz essa avaliação e aí depois faz uma recuperação ou faz um fechamento.

P. E aí como que vocês utilizam essa avaliação diagnóstica para planejar? Ela é utilizada no planejamento ou não?

P5. [Não] ${ }^{37}$ [ela vem como uma avaliação mesmo.] ${ }^{38}$

P. Tá. Então na hora do planejamento você considera a realidade dos alunos, assim?

P5. $[\text { Sim. }]^{39}$

P. Como que é feito isso?

P5. Olha a gente [tem uma característica na escola] ${ }^{40}$, né. Que a maioria são alunos, principalmente no noturno, antes eram trabalhadores, hoje não é mais. A gente tem uma grande maioria de alunos que não é trabalhador. Maioria são menores. Então a gente vai vendo cada característica. Muitos moram longe, pegam ônibus prá ir prá escola. Então a maioria não é... São de classe média baixa. Então tudo isso a gente leva em 
conta. Lá também tem assim...Muitos alunos acabam trabalhando em supermercado, né. Então são poucos alunos que dão seqüência nos estudos. A maioria que tão lá ou trabalham no shopping ou trabalham no mercado. Então [a gente acaba pegando essa realidade deles e utilizando em sala de aula. $]^{41}$

P. Quais são as suas referências teóricas para o planejamento? Na hora de fazer o seu planejamento em que referencial você se baseia?

P5. No [PCN.] $]^{42}$

P. No PCN? Você conhece o PCN?

P5. [Não o sei inteiro, mas a gente consulta e estuda bastante. $]^{43}$

P. É feito o registro do planejamento de cada aula? Porque aqui você fala prá mim que você planeja as aulas também. Assim né, aula por aula. Então você faz o registro desse planejamento por aula?

P5. O registro no diário você está dizendo?

P. É, não, de alguma forma. Você tem um registro do que você vai fazer naquela aula?

P5. Porque eu acabo... Vou arquivando, entendeu? E acabo depois [o registro vai só no diário. $]^{44}$ [Não tenho assim um planejamento para entregar de aula] ${ }^{45}$, não.

P. Então como você se prepara prá dar a aula daquele dia, por exemplo? Como que você sabe o que você vai fazer naquele dia?

P5. Ah não. [lsso eu já tenho planejado assim, quando eu fecho o bimestre.] ${ }^{46}$ Então eu vou trabalhar...Eu já separo os textos, atividades, se vai ter aula experimental se não vai ter. Então isso já no bimestre de quando eu pego o tema. Então eu já sei, seleciono quais textos vão ser, quais atividades, se vai ter que...Nesse bimestre no tabagismo eu vou trabalhar...O fechamento vai ser um debate, né. Como eu trabalhei no álcool. Algumas turmas vão ser seminários e eu dei a opção, ao invés de seminário pode ser teatro, né. Então assim vai ter um fechamento, então eu [já tenho começo, meio e fim. $]^{47}$

P. Tá. Aí você só vai seguindo essa seqüência?

P5. Isso. [Mas registrado não.] ${ }^{48}$

P. Tá. Como está sendo então, ter que planejar as aulas do Labvirt? Você acha que é necessário?

P5. [Sim.] ${ }^{49}$

P. Está sendo fácil planejar? Porque lá você tem que planejar aula a aula exatamente o que você vai fazer. Como é que está sendo fazer esse planejamento?

P5. Olha. [Não está assim... $]^{50}$ [Eu não tenho o hábito de registrar essa aula a aula $]^{51}$, mas [eu já tenho uma seqüência] ${ }^{52}$ então, tanto é que lá, eu estava conversando com a Lu, na questão do que vai ser os próximos passos. Eles já começaram, eu já tenho 
as idéias prévias...Eu tô na briga prá conseguir usar o laboratório de informática, que eles não querem deixar. Então eu me propus a ir fora do horário e fazer uma atividade com uma simulação, prá ser um prévio, e aí sim engajar eles no projeto. Por que tô seguindo, mas não muito certinho. Com algumas...Porque eu percebi assim, que quando eles entregaram o relatório eu percebi assim que muitos se perderam eles não entenderam o que era. Eu conversei com o Eri, eu conversei com o Fábio prá me direcionar o que eu poderia dar de retorno prá cada grupo. E somente dois grupos conseguiram entender o que era, mas eu não sei se... Porque nas férias eles deveriam pesquisar. Eu não sei se eles vão me trazer esse retorno. Então o quê que eu vou fazer, vou dar uma atividade que é a da jóia, mas eles vão ter que me entregar individual. Como se fosse uma avaliação. E aí prá ver se eles entendem essa...Juntar o conteúdo, com a interação, com a situação problema prá ver se eles conseguem dar continuidade.

P. Então a sua aplicação do seu módulo ainda não terminou? Você está no meio da aplicação do seu módulo?

P5. Não tô no começo ainda.

P. Você acha que esse procedimento de, é que você está no comecinho então não deu prá você sentir muito assim, mas você tem que planejar o Labvirt aula a aula, e eu queria saber se você acha que esse procedimento auxilia ou dificulta a sua prática?

P5. Olha, [eu acho que não interfere] ${ }^{53}$, porque a partir do momento que você planejou, você tem uma seqüência, você sabe qual é seu começo, qual meio, qual o fim então você pode ter algumas alterações, mas isso não interfere.

P. Você chega a se sentir mais segura? Vou chegar lá vou olhar e já sei o que vou dar?

P5. Não prá mim já é tranqüilo.

P. Qual que é a sua concepção de ensino?

P5. Ensino?

P. É.

P5. Eu acho que ensino é você [auxiliar o aluno a compreender o mundo.] ${ }^{54}$ Compreender as transformações, no caso da disciplina de Química, compreender a interação dele, qual é o papel dele, o quê que ele pode fazer prá melhorar, o quê que ele faz, entender o próprio corpo. Eu acho que ensino é isso. Você [fazer essa ligação essa mediação do aluno com o mundo. $]^{55}$

P. Você acha que o planejamento que você elabora está de acordo com essa concepção?

P5. [Eu acho que sim. $]^{56}$

P. Durante a sua formação inicial, foi discutido/ensinado alguma coisa sobre como planejar? 
P5. [Foi, na aula de metodologia] ${ }^{57}$, mas... [era básico ${ }^{58}$, né. Você tinha que escrever... [Não foi assim auxiliado como, as alternativas, as possibilidades.] ${ }^{59}$ [Foi só cobrada uma coisa que a gente pôs no papel e entregou. $]^{60}$

P. E aí você aprendeu a fazer o seu planejamento como?

P5. [Fazendo.] ${ }^{61}$ Só que assim, quando você entra no Estado, normalmente os mais velhos, falam assim: - Olha tá pronto, copia do ano passado. E por uns tempos você faz isso, até você adquirir uma segurança de você mesmo planejar o seu, não simplesmente copiar o dos outros. 


\section{ENTREVISTA COM P6 (11 DE NOVEMBRO DE 2005)}

P. Você elabora seu planejamento de ensino por necessidade ou para cumprir normas burocráticas?

P6. [Não.] ${ }^{1}$ Porque [nós precisamos ter uma noção do que vai ser passado para os alunos.] ${ }^{2}$ [Se não eu fico perdida] ${ }^{3}$, não sei em que passo estou. Eu converso muito com a outra professora, porque não são os mesmos alunos os 3 anos. Nós mudamos a sala. Então se nós não tivermos um planejamento e as duas estarem mais ou menos ali, a gente se perde. $O$ aluno vê 3 vezes a mesma coisa, outra coisa não vê. É uma bagunça.

P. Prá organizar o trabalho?

P6. [É prá trabalhar. $]^{4}$

P. Você consulta este planejamento ao longo do ano, ou você sabe o que fez e entrega prá diretoria?

P6. Não. [Antigamente era assim.] ${ }^{5}$ Tanto é que nos tínhamos esse planejamento que era mandado prá diretoria e o nosso, que nos sentávamos e falávamos e vamos trabalhar isso, desse jeito, desse jeito... durante o ano era isso. Agora nós fizemos [o nosso planejamento igual ao da direção da escola. $]^{6}$ Tudo igual.

P. Em que momento é feito o planejamento na escola? Quantos dias são dedicados?

P6. [São três dias de planejamento.] ${ }^{7}$ Agora [pra sentar os professores da área prá ver o que vai ser feito, o que não vai ser feito e como vai ser feito, aí é uma conversa no meio dos corredores] ${ }^{8}$, mesmo. [Ou quando não tem aluno que nós sentamos e conversamos ou pelo telefone. $]^{9}$

P. Então naquele momento que a escola prepara vocês não conseguem parar prá planejar?

P6. Prá planejar, não. [É mais uma conversa entre os professores $]^{10}$, alguma coisa assim, mas planejar?

P. Então o planejamento é discutido com a Regina, outra professora da mesma disciplina?

P6. [Converso com a professora de biologia, de educação artística.] ${ }^{11}$

$P$. Você acha que isso é importante, é necessário?

P6. [Eu acho. ${ }^{12}$ Porque senão os alunos vão ficar pensando prá que que estou aprendendo isso. Se colocar em várias disciplinas [eles sabem que tem uma relação com outra. $]^{13}$ 
P. Quando você coloca "é considerado a clientela da escola prá planejar", o que você considera desta clientela?

P6. [De onde eles vêm. ${ }^{14} \mathrm{O}$ tipo de aluno. [Nós conhecemos nossos alunos.] ${ }^{15} \mathrm{Se}$ a gente não conhece, nós fazemos o planejamento e se precisamos refazemos o planejamento. Porque não adianta colocar 500 conteúdos e o menino não saber nem escrever o nome. Aí começa do básico prá continuar.

P. E esse replanejamento é registrado e anexado ao planejamento inicial ou é uma coisa imediata?

P6. É. Nós falamos não dá prá fazer assim vamos fazer de outro jeito. Mas [a gente não registra. $]^{16}$

P. Vocês fazem uma [avaliação diagnóstica no início do ano?] ${ }^{17}$

P6. [Não.] ${ }^{18}$ Eu faço assim, uma revisão do que eles teriam que ter visto na $8^{a}$ série e que muitos não viram e alguns exercícios. [A clientela é muito diferente.] ${ }^{19}$ Pelo menos o básico eles tem que ver. Se eles estão precisando fazer um vestibular, um vestibulinho eles precisam saber pelo menos a base. Então eu fico com dó de não dar nada, dar só o mínimo do mínimo da $8^{a}$ série e de repente os meninos saírem daqui sem saber nada. Eu gosto de passar, de falar eles sabem alguma coisa.

P. Como referência para o planejamento você cita os vestibulares. Os seus alunos pensam em fazer vestibular? Quantos deles?

P6. A maioria. No $3^{\circ}$ muitos vão fazer cursinho. Para concurso público, escola técnica. Então eu tento [dar o máximo possível para que eles consigam se dar bem na vida. $]^{20}$ Se não o que é que eles vão fazer. Não tem uma profissão, não tem nada.

P. Quais são suas referências didáticas para o planejamento?

P6. [Livros, apostilas] ${ }^{21}$, coisas assim. [Livros didáticos.] $]^{22}$

P. Você faz um planejamento de cada aula?

P6. Eu costumo fazer.

P. Como que ele é feito?

P6. Eu sento e vejo essa sala. Normalmente elas são na mesma seqüência. Vou fazer isso, vou fazer aquilo. De repente uma sala é muito adiantada, então eu passo mais exercícios. Outra sala empaca, então tem que parar refazer, passar outros exercícios, ver onde eles estão errando.

P. Você registra estes planejamentos?

P6. [Passo no diário de classe. $]^{23}$

$P$. Porque é que no planejamento que vocês me mandaram não constam objetivos gerais, recursos didáticos, metodologia e avaliação? Vocês não pensam nestes tópicos no momento do planejamento? 
P6. Eu acho que é assim tão normal prá gente. Porque como nós duas estamos sempre juntas, conversando, acho que acabou escapando. Porque [a gente já sabe mais ou menos o que vai usar. $]^{24}$ [Vai usar giz, sala de informática, laboratório, biblioteca... acho que a gente acabou esquecendo deste pequeno detalhe.] ${ }^{25}$

$P$. Mas vocês pensam nisso na hora do planejamento?

P6. Ah sim. Tanto que eu falo, tal dia o laboratório é meu.

P. Neste planejamento vocês listam todo conteúdo de Química para o EM. Em que você se baseia prá fazer essa seleção de conteúdo?

P6. Como eu falei, eles [têm que saber o básico.] ${ }^{26}$ É o [conteúdo que eles vão ter prá fazer um vestibular, prá fazer um concurso] ${ }^{27}$, prá fazer tudo. Então eu não consigo enxergar o que é mais importante. O que é mais importante prá um, pode não ser pro outro.

P. Então vamos supor que você tenha que excluir algum conteúdo daqui por algum motivo, o que você consideraria prá excluir esse conteúdo?

P6. [Eu considero o que tenha mais a ver com o cotidiano deles.] ${ }^{28}$

P. Você consegue cumprir todo o planejamento?

P6. Nem sempre. Algumas salas eu consigo chegar onde eu quero, mas outras não.

P. Você tem que planejar as aulas do Labvirt. Você acha que é necessário, planejar aula a aula?

P6. [Eu acho. $]^{29}$ [Eu faço a lápis mesmo no final do diário. $]^{30}$ Porque [se eu não tenho uma seqüência eu me perco.] $]^{31}$ Só que o planejamento do Labvirt, você planeja, replaneja... porque não dá prá cumprir... Você tenta deixar um numero $\mathrm{x}$ de aulas e é o dobro.

P. Você sentiu alguma dificuldade em planejar aula a aula do Labvirt?

P6. Não. Foi normal. A única coisa é que é meio frustante por não dar certo.

P. Em que medida esse planejamento aula a aula auxilia ou dificulta a prática do professor?

P6. [Prá mim só auxilia] ${ }^{32}$, porque [eu não sei trabalhar se eu não tenho uma seqüência lógica. ${ }^{33}$ Tem gente que se dá super bem. Mas com o número de salas que eu tenho, eu me perco.

P. Qual a sua concepção de ensino?

P6. É uma coisa bem diferente do que eu estou vendo hoje. [Eu gostaria que fosse prá pessoa entender um pouco mais a respeito do mundo das coisas que estão ao seu redor. $]^{34}$

P. Você acha que o seu planejamento está de acordo com a sua concepção? 
P6. Eu acho que está indo no caminho, entendeu. Eu gostaria assim que os meus alunos entendessem um pouco mais, que eles tentassem aprender. Mas o que eu vejo é que muitas vezes eles não estão nem aí porque o pai e a mãe não estão nem aí. Ninguém está nem aí com a hora no Brasil. Isso me dá um desespero.

P. Na sua graduação, foi discutido, foi ensinado e aprendido alguma coisa sobre como planejar?

P6. [Não.] $]^{35}$ Eles só ensinaram os autores. Nem como lidar numa sala de aula.

P. Então como foi seu primeiro dia de escola?

P6. Me colocaram como eventual na sala de aula e disseram você vai dar a matéria. Eu não tinha planejamento nenhum, não tinha nada, não sabia nada, fiquei perdida. E nos outros anos foram feitos planejamentos com os professores e aquilo que eu achava que estava bom eu dava e o que não achava eu excluía. Até agora foi nós que sentamos e fizemos, e isso é o que nós pensamos. 


\section{ENTREVISTA COM P7 (11 DE NOVEMBRO DE 2005)}

P. Você elabora seu planejamento de ensino por necessidade ou para cumprir normas burocráticas?

P7. [As duas coisas.] ${ }^{1}$ Aqui na escola nós adotamos o livro. Então como adota livro didático eu tenho que [seguir essa norma burocrática da escola que eu tenho que seguir o livro.] ${ }^{2} \mathrm{E}$ [por necessidade porque tem coisas no livro que não são tão importantes e a gente tem que dar porque o pai cobra que aquela parte do livro não foi usada e coisas que são mais importantes, assuntos que você tem que dar maior importância que o livro trata muita vezes de uma forma superficial.] ${ }^{3}$ Então acaba cumprindo as duas partes.

$P$. E você acha que ele é por necessidade em que sentido?

P7. No sentido da construção do conhecimento do aluno. Nesse fator. Então é... aquilo também que eu julgo ser importante dentro da Química...então a gente acaba dando maior ênfase nisso daí. Agora a gente leva em conta o aluno o que ele tem de conhecimento que geralmente... por menos pessimista que eu possa ser a bagagem é sempre muito pequena, muito. Então é nesse sentido.

P. E você consulta seu planejamento ao longo do ano?

P7. Então aqui na escola a gente tinha um planejamento medíocre. E a direção anterior, ela não deixou que a gente alterasse porque ela falava que ela tinha um plano prá 4 anos, um plano diretor, e que esse plano diretor só podia sofrer pequenas adequações. Então a gente nunca conseguiu mudar. Quem fez esse planejamento eu não sei por que há 4 anos atrás eu não estava aqui. [O planejamento que eu tinha era totalmente diferente e no plano diretor é um planejamento de meia página... prá 3 anos. Então eu não sei de onde veio e eu não seguia isso daí. Eu seguia um que eu tinha assim... rascunhado num caderno. $]^{4} \mathrm{E}$ quando eu barrava em alguma coisa com algum aluno eu tinha que estar documentada em cima daquilo que tinha na escola. Então nunca tava documentada. Pois daquilo não tinha nada. Então eu seguia assim. Aí esse ano, com a troca da direção, [eu e a Juliana vamos fazer um planejamento diferente] ${ }^{5}$, tudo... A gente começou a fazer quando bateu com a sua orientação lá no Labvirt. $E$ aí nós pensamos, vamos seguir aquela orientação e vamos tentar fazer alguma coisa diferente pros próximos anos, porque essa direção já pediu que o ano que vem ela vai mudar tudo... ela tá mudando todo o plano diretor... inclusive tá entrando o Labvirt no plano diretor.

P. Em que momento é feito o planejamento da sua escola? Quantos dias são dedicados a ele? 
P7. Geralmente nós temos dois momentos: [no início do ano, nós damos uma semana de aula, uns 10 dias de aula, uma coisa assim e aí paramos... $]^{6}$ a maioria das vezes bate com a semana do Carnaval. Quando nós retornamos, aí isso é como planejamento. Até esse ano, [nunca paramos para fazer planejamento.] ${ }^{7}$ [Nós paramos, aí nós temos dinâmicas, temos discussões... nós temos regras disciplinares, nós temos tudo isso e o planejamento depois é assim: Olha, agora, faltando uma hora prá terminar o último - terceiro dia da parada do planejamento] ${ }^{8}$ [...] então não sobra tempo pro planejamento, aí sobra uma hora. Aqui na escola, a partir da metade do ano passado é que existe outra professora de Química e que nós podemos sentar e conversar. Porque até então eu era sozinha e quando tinha que brigar pelo planejamento, uma andorinha só não fazia verão. E depois o outro momento [é no meio do ano.] Aí no meio do ano tem a avaliação do período no primeiro semestre que parava também dois dias, né. $E$ tudo aquilo que a gente faz, [levantamento de diagnóstico do aluno, tudo que poderia estar sendo usado nesse período a gente não usa. ${ }^{10}$

P. Então você discute esse planejamento com a Juliana. Você acha que é útil essa discussão com outra pessoa? Por quê?

P7. Ah sim! [Porque de repente aquilo que eu acho importante é uma coisa que eu gosto na Química e não que realmente seja importante] ${ }^{11}$, né. [Então quando a gente discute você tira esse lado emocional e fica um lado mais na razão: ${ }^{12}$ Não olha, realmente isso tem importância. Vamos dedicar mais atenção a este fato e não a este. Ah mas eu gosto...Gostoso. Gostar, gostoso não tem....

$P$. Você diz no questionário que é importante replanejar para nortear o seu trabalho. O que significa esse "nortear o seu trabalho"? O que você faz?

P7. [Se eu percebo dificuldade dos alunos...] ${ }^{13}$ Muitas vezes dentro daquele assunto você explica e reexplica, tenta mil e uma formas diferentes e você acaba não atingido o aluno. E em outro assunto que puxe, que dá prá você puxar aquele assunto anterior, então... às vezes você consegue, né ... esclarecer melhor... aí aparece aquela luzinha que o aluno - Ah agora que eu entendi aquilo que você tava falando, né. E fora isso, muitas vezes, a maioria das vezes, [o replanejar nosso é - Não vou dar conta de fazer tudo porque não tenho aula, porque não tive isso, por causa daquele projeto que ficou mais uma semana sem aula, ou tirei uma licença saúde...então você acaba replanejando também por causa disso. ${ }^{14} \mathrm{Na}$ sala de aula é mais ou menos constante, muitas vezes você faz sem saber que está fazendo, né... quando você retoma alguma coisa, repensa naquilo que você fez. [Mas na maioria das vezes é prá cumprir um prazo, uma entrega de conceitos que você não vai cumprir.] ${ }^{15}$ [Agora de um ano prá outro, não deu certo daquele jeito vou tentar desta outra forma. ${ }^{16}$ [Isso eu acho que já faz parte do cotidiano. $^{17}$ [Um monte de ano de magistério você já acaba fazendo isso meio que 
automático. ${ }^{18}$ [Eu procuro diversificar, procuro não ficar na mesmice.] ${ }^{19}$ [É difícil eu usar uma atividade que eu preparei o ano passado e simplesmente pegar esse ano e tirar xérox. $]^{20}$ Eu vejo um monte de gente fazendo isso e eu não consigo. Eu fico brava comigo. Por outro lado eu durmo com a minha consciência tranqüila. [Mas cada ano é uma realidade diferente. $]^{21}$

P. Como é que você faz prá considerar essa clientela da escola prá planejar?

P7. [No inicio do ano a gente faz uma avaliação diagnóstica.] $]^{22}$ Nós pegamos os alunos, [eles respondem algumas questões que a gente elabora através de um texto, de uma interpretação prá ver se ele consegue fazer isso daí] ${ }^{23}$, né. A gente faz uma leitura assim, meio cansativa prá ver se ele realmente tem paciência para aquele tipo de leitura que exigiria mais dele, que teria um conhecimento maior, assim. Então a gente pega isso daí. Mas não é com todo mundo não. É um grupo de professores que são os mais antigos da escola. E a gente parte disso daí.

$P$. E a partir dessas informações você faz o seu planejamento?

P7. É. Diferente do que a gente está fazendo agora. Agora [eu já conheço os alunos, tudo. $]^{24}$ [E em vista do que a gente conhece dos alunos desse ano, nós montamos o $1^{\circ}$ ano do ano que vem. $]^{25}$ Que é esse planejamento que vai ficar aí digitado, fixo... vamos dizer assim. E que com certeza será adaptado pro ano que vem em alguma coisa. Porque, é..., é planejamento. As minhas salas geralmente são de 2 e de 3, então [eu já tenho informação dos outros professores sobre o conhecimento que os alunos já têm, que já adquiriram. $]^{26} \mathrm{E}$ também assim... eu me baseio muito, como eu tenho $2^{\circ}$ ano, $2^{\circ}$ ano tem muito cálculo, então [eu me baseio muito nas informações dos professores de matemática $]^{27}$, não me prendo nem na Química, porque você passa o conceito mas ele não consegue produzir depois. Agora está mudando as coisas aqui na escola, mas até o ano passado eu tinha que ter as provas dos alunos. Eu tinha que mostrar alguma coisa, porque a diretora só se preocupava com os recursos. Ela não se preocupava com o conhecimento do aluno. Era outro enfoque. Então é uma experiência um pouco nova prá gente. Tanto é que nós tínhamos as DPs, e pro ano que vem estão querendo acabar com isso na escola.

P. O replanejamento feito no meio do ano é registrado e anexado ao planejamento inicial?

P7. Não. Isso é o que ela (diretora) chama de adequação ao plano. Então, nós fazemos e depois no relatório final do ano ela faz algumas perguntas básicas: "Você cumpriu o planejamento? Sim ou não?" Se sim justifique, se não justifique. E fica uma justificativa assim: "Não consegui devido à falta de tempo, o número reduzido das minhas aulas, as aulas eram sempre de sexta feira". É mais uma orientação pro professor do ano que vem falar assim: "Ah essa turma aqui, oh. Essa turma eu parei nesse assunto então 
você começa daí". Não é um replanejar assim: "Olha, esse conteúdo eles aprenderam rapidinho dá prá mudar prá 2 aulas e não 4. Esse daqui eles não entenderam muda prá 6. [Não é uma coisa bem direcionada assim não. É muito superficial.] ${ }^{28}$

P. Como referência para o seu planejamento você cita os vestibulares. Os seus alunos pensam em prestar vestibular? Quantos deles?

P7. $30 \%$. É uma coisa que a gente tenta incentivar muito aqui na escola porque nós sempre tivemos um índice alto de alunos prestando vestibular e entrando em faculdades. $\mathrm{E}$ de uns tempos prá cá a gente tá percebendo que isso tá caindo muito. Então a gente tá tentando incentivar bastante. Aqui na região a nossa escola já foi muito mais cotada do que é hoje em termos de um ensino de qualidade. E a gente tá tentando resgatar isso daí. Com um aluno totalmente diferente do que era anos atrás. Porque hoje a gente percebe que eles não têm incentivo em casa, que eles não gostam de uma leitura, eles querem assim, uma coisa mais pronta, né. Se eu der uma coisa pronta, passo a passo, uma receitinha, ele deslancha naquilo, mas se você tirar a receita ele não faz. Então a gente tá tentando mudar isso. É uma situação que nós não somos condizentes com ela, mas que ela tá no mundo aí e a gente tá tentando aprender a trabalhar com ela. Não a trabalhar com ela, mudar.

P. Mas aqui tem a adesão de todos os professores prá isso?

P7. Não. Do grupo dos mais antigos, sim. Porque aqui na escola nós temos muitos professores efetivos, né. Então, por exemplo, o período da tarde da escola não está bem cotado com a comunidade. Mas o período da manha é super bem visto, que é o EM. A gente tem bastantes pais na reunião de pais. Diferente do período da tarde que vem bastante também, mas com a finalidade de simplesmente pegar nota. De manhã não. A gente conta com os pais na cobrança mesmo do aluno. Nós temos pais que vem cobrar a gente: "Olha, meu filho está tendo isso no cursinho e falou que não viu isso com você. Mas é a minoria. Dá uns $30 \%$.

P. Quais seriam as referências didáticas pro seu planejamento?

P7. Nós temos que seguir os PCNs. [A gente se baseia nos PCNS.] ${ }^{29}$ [O livro didático que eu uso aqui é o Química Essencial.] ${ }^{30}$ Que é essencial mesmo. Nós usávamos outro, que a gente teve que se adequar, nos baixamos o nível. Como eu dou aula no laboratório eu tenho o recurso de fazer algumas experiências durante as aulas. [...] Nós recebemos a [Veja e a Nova Escola.] ${ }^{31}$ Então a gente tem esse apoio também de textos, notícias... E aqui na escola, agora, sala de informática. A biblioteca já foi melhor do que hoje. Muitos livros sumiram. E a gente tem o recurso do vídeo. Na diretoria, há alguns anos atrás, nós podíamos pegar alguns vídeos e eles tinham um acervo bem atualizado. O acervo não está mais assim. É grande o acervo, mas não é mais atual.

$P$. Todos os alunos têm o livro? 
P7. Não. Como a gente adota o livro, os alunos que saem vendem o livro com o preço mais acessível. E na editora a gente já negocia com eles logo de cara "Quantos livros, do professor mesmo, você vai me dar na venda desses daqui. Então, por exemplo, nesse ano a gente ganhou prá escola 15 exemplares. Então esses exemplares ficam conosco na sala de aula. Aí, se eu vou cobrar alguma coisa que ele tem que me entregar na próxima aula, eu empresto o livro. Ele sabe que tem que me entregar no dia seguinte. Na minha sala eles trabalham em grupo o tempo todo. Então ajuda.

$P$. Nesse planejamento que você entregou não foram colocados objetivos gerais, recursos didáticos, metodologia e avaliação. Você não pensa nesses tópicos no momento do planejamento?

P7. A gente pensa. [Foi falta de tempo.] ${ }^{32}$ [Como a gente sabe que essas paradas não são muito produtivas no início do ano, e no meio do ano, quando acontece um dia como hoje, que era prá gente ter aluno e não tem, a gente acaba subindo e fazendo alguma coisa.] ${ }^{33}$ Vamos tentar fazer os objetivos que a gente quer alcançar... Então a gente vai fazendo isso. $\mathrm{E}$ como você viu a maioria [a gente foi pegando de livros, pela falta de tempo] $]^{34}$, "Olha isso daqui tá legal... olha isso daqui não...vamos misturar esses dois...e foi mais ou menos assim. Cai dentro com o que a gente tá querendo? Cai. Então vamos pegar." [Não é uma coisa que a gente sentou e produziu realmente aquela frase.] ${ }^{35}$ Porque, do jeito que tá não dá prá continuar, não dá prá usar e tempo prá sentar realmente, elaborar do jeitinho que tem que ser não tá tendo. Eu tenho outra escola a Juliana também. Vamos tentar melhorar. E aí nós fomos fazendo um rabisco e quando eu fui tendo tempo eu fui passando a limpo no computador. Fui digitando. Vamos digitar prá não perder. E acabamos fazendo o ano inteiro. Agora a gente tem que sentar. Conforme a gente foi fazendo foram surgindo as idéias. "Olha, dá prá gente fazer isso aqui." Então [alguma coisa rabiscada em algum lugar a gente tem.] ${ }^{36}$ Mas precisa ainda aprimorar. Mas a gente pensa sim. Sem dúvida nenhuma. Foi a falta de tempo mesmo.

P. No planejamento que vocês fizeram contempla todo conteúdo de Química pro EM praticamente. Em que é que vocês se baseiam prá selecionar este conteúdo?

P7. [Foi o livro.] ${ }^{37}$ [Como eu tenho que seguir o livro didático] ${ }^{38}$, [o livro tem tudo, nos vamos dar tudo. $]^{39}$ Agora tem tópicos ali que nós colocamos 1 ou 2 objetivos porque a gente não acha tão importante. E outros não. A gente detalhou mais porque a gente acredita ser um assunto que realmente envolva mais conhecimento.

P. Caso você tenha que excluir algum conteúdo daqui, por algum motivo. O que você consideraria prá tirar um e não outro?

P7. [A princípio o tempo. $]^{40}$ [...] A gente acaba colocando tudo. E o que é que eu vou descartar? [Eu posso até descartar algum tópico que eu não acho tão importante] ${ }^{41}$ mas no final vou enxugando por causa do tempo. Então isso daqui. Vamos dar a base 
prá ele saber o que é que significa isso. Vamos por exceções? Não, esquece das exceções. E esses casos? Não, esquece dos casos. E aquilo lá? Isso não é tão usado. E acaba fazendo alguma coisa assim. Há muito tempo atrás, eu tive uma orientação lá no GEPEQ, que era a parte da atomística, de quando a gente entrava nos números quânticos essas coisas. Isso a gente não dá aqui. Também acho que não é importante a nível de EM. E a gente acaba colocando no planejamento por causa do livro didático. Então a gente tem, mas a gente não se prende com eles na parte de números quânticos não. Geralmente é um assunto que a gente acaba pulando. A gente explica que se for dar toda teoria quântica, não existe conhecimento suficiente prá isso, mas a gente cita do livro, olha existe...tudo mais. Mas aqueles exercícios de fazer a distribuição e puxar os números quânticos, a gente já não faz aqui há muito tempo. Distribuição sim, em camadas, usa o diagrama, explica o que é que é. Mas aquela cobrança de números quânticos não. Mas a gente questiona, porque eu fui uma vez numa reunião do vestibular da Unicamp. E eles frizaram muito bem, que o negócio deles é conteúdo e ponto final. Então nós até discutimos isso lá no Labvirt. Se não é importante, se não tem fundamentação, se não tem nível prá isso, porque é cobrado isso no vestibular? Então são linhas de pensamento diferentes, de quem prepara o vestibular e de quem dá aula.

P. Por que você acha que tem que constar no seu planejamento já que você não vai dar?

P7. Eu só tenho a noção no meu planejamento. Se você olhar no meu objetivo é só uma noção. Não é um conteúdo aprofundado dele. [Porque no livro tem e os alunos cobram e os pais cobram. $]^{42}$ Esse $30 \%$ que a gente tem que... está fazendo cursinho, que quer fazer uma faculdade tudo mais, é o $30 \%$ de pais que a gente tem na reunião sempre e que cobra uma atitude do professor. Então, antigamente a gente se preocupava com o geral, hoje não. Hoje a gente se preocupa com quem tá com vontade porque infelizmente...uma vez eu ouvi assim: "que é o professor que motiva o aluno, que é o professor que dá exemplo, que é o professor que incentiva, que faz tudo isso". Se for isso, eu estou com a consciência tranqüila, porque eles me vêem sempre lendo, eles me vêem sempre buscando coisas novas, eles me vêem sempre preocupada com conteúdo e sempre...vou de mesa em mesa, difícil eles me verem sentada. Então, se é o exemplo do professor. Eles têm. Eu não acredito. Eu acho que eu faço parte do contexto. Mas a minha parte de motivação e de incentivo é muito pequena. Eu sempre ouço assim: "Você não usa essa palavra porque isso vai refletir contra você". Eu não acho não.

$P$. Então você não consegue cumprir todos os conteúdos que você planeja?

P7. Não. Esse ano eu não vou conseguir cumprir o programa de orgânica. O que eu vou alegar: Hoje não tenho aluno. A semana que vem é o projeto hip-hop, não tenho aluno de novo. E o conteúdo? Foi pro espaço. 
P. Você faz um planejamento diferenciado para cada turma ou é o mesmo prá todas elas? Da mesma forma que você trabalha no $2 \mathrm{~A}$ você trabalha no $2 \mathrm{~B}$ ?

P7. [O planejamento da escola é único. Agora a forma de trabalhar não. $]^{43}[A$ produtividade de cada sala é diferente. $]^{44}$ Então, em umas avança mais no conteúdo e outras não. [O mesmo conteúdo é trabalho de forma diferenciada. ${ }^{45}$ [O exercício não é no mesmo nível de complexidade. $]^{46}$

P. Como está sendo ter que planejar as aulas do Labvirt? Aula a aula. Você acha que é necessário?

P7. Nós fizemos o planejamento e não seguimos nenhum. Porque quando não dava problema na sala de informática, dava problema na biblioteca, dava problema no projeto da escola, batia com o campeonato. Ou então era uma semana que os alunos emendavam, ou caia na semana de provas. Eu não conseguia produzir nada. Então quando implantou na escola, uma realidade totalmente nova prá mim. Nunca tinha mexido em nada disso. Foi a primeira experiência.

P. E ter que fazer esse planejamento foi tranqüilo?

P7. [Foi porque planejar é fácil.] ${ }^{47}$ [Executar o planejamento que é o problema.] ${ }^{48}$ Então, fiz o planejamento. Foi analisado, veio uma resposta. [...] Mas não consegui aplicar, principalmente por causa dos problemas com a sala da informática. [...] Tentei aplicar com 4 salas que se mostraram interessadas, mas não consegui fazer nada. Após adequar a sala de informática, preparamos outro planejamento para turmas novas. [...]

$P$. Você acha que é necessário esse planejamento aula a aula que eles pedem? Dificulta ou facilita?

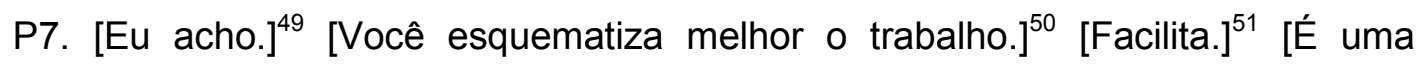
orientação.] $^{52}$ [Você sabe quanto tempo você vai gastar, quanto tempo você tem prá fazer, o nível que esta chegando os alunos. $]^{53}$ Agora, ata e rubrica não consegui. [...]

P. Qual é a sua concepção de ensino? O que você entende por ensino?

P7. Não tem uma pergunta mais fácil? Sinceramente, [pra que eu ensino eu não sei.] ${ }^{54}$ Antigamente, eu acho que eu até sabia, hoje eu acho que eu não sei mais. Eu acho que [hoje eu ensino porque eu tenho que ter um trabalho, então eu venho prá escola dar aula. $]^{55}$ Mas, eu acho que [o ensino é uma coisa fundamental. $]^{56}$ [Eu acho que ele direciona o que você pretende ser e ter na vida. ${ }^{57}$ [Eu acho que o ensino é aquilo que vai dar rumo prá você.. $]^{58}$ Te orientar, um sentido que você vai ter na sua vida. Não acho que é aquilo de aprender de acumular. Acho que não. Vai traçar você. Vai mostrar aquilo que você é. Vai demonstrar prá alguém aquilo que ele pode ser.

P. E você acha que seu planejamento está de acordo com essa sua concepção?

P7. Ah eu acho que tá porque eu trago tanta coisa da atualidade prá eles. Texto..., quadro com mensagens. Eu valorizo muito a auto-estima do aluno. Eu trabalho isso daí. 
Eu coloco parabéns no dia do aniversário de cada aluno meu. Não é só centrado no conteúdo. Eu mostro lições de vida. Eu sempre tenho algum artigo que foi publicado. Eles pedem isso no quadro. Mostro como a vida é.

P. Quando você estudou, na sua graduação, você teve alguma coisa sobre planejamento? Foi discutido ou foi ensinado alguma coisa sobre planejamento ou de como planejar?

P7. Eu tive... [alguma coisa eu tive sim.] ${ }^{59}$ Eu lembro que eu [tiver que fazer um planejamento e eu nem sabia de onde tirar aquilo. ${ }^{60}$ Foi uma coisa assim, tem que entregar, tem que fazer. Nas aulas de didática, a professora colocava alguma coisa e [...] Eu lembro que eu fiz um planejamento em Ciências de uma série e não do curso.

P. Então você acabou aprendendo a fazer na prática aqui do dia a dia?

P7. Exatamente. Porque eu lembro que eu fiz aquele planejamento, mas não foi nada assim olha. O que é conteúdo, o que é objetivo, o que é, o que é... Então [eu devo ter pego um livro e copiei e foi aquilo.] ${ }^{61}$ Se estava certo ou errado? 


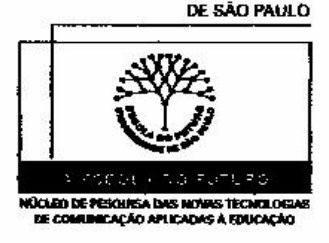

\section{QUESTIONÁRIO SOBRE O PLANEJAMENTO (ENCONTRO 22/09/2005)}

1) Vofê já conseguiu aplicar o projeto? Se não, porquê?

2) Para aplicar o projeto, foi elaborado um planejamento?

fin for ela bou do

3) Você sentiu dificuldades para fazer este planejamento? Quais?

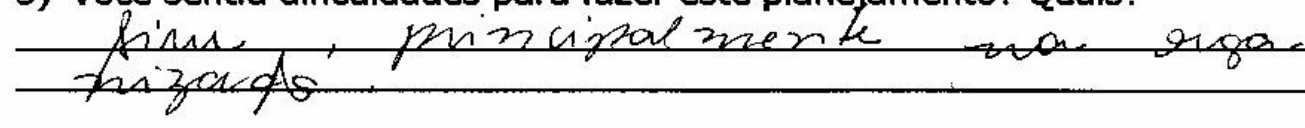

4) Este planejamento facilitou a aplicação do projeto? Explique.

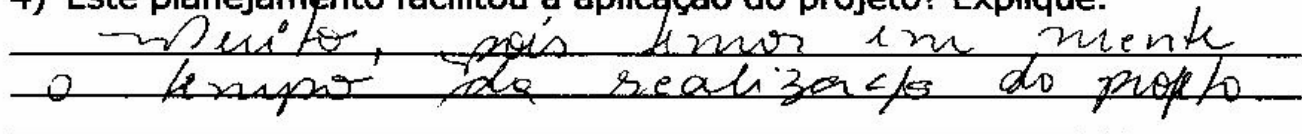
5) Você conseguiu seguir o planejamento como havia pensado ou foi
necessário fazer alguma mudança? Quais?

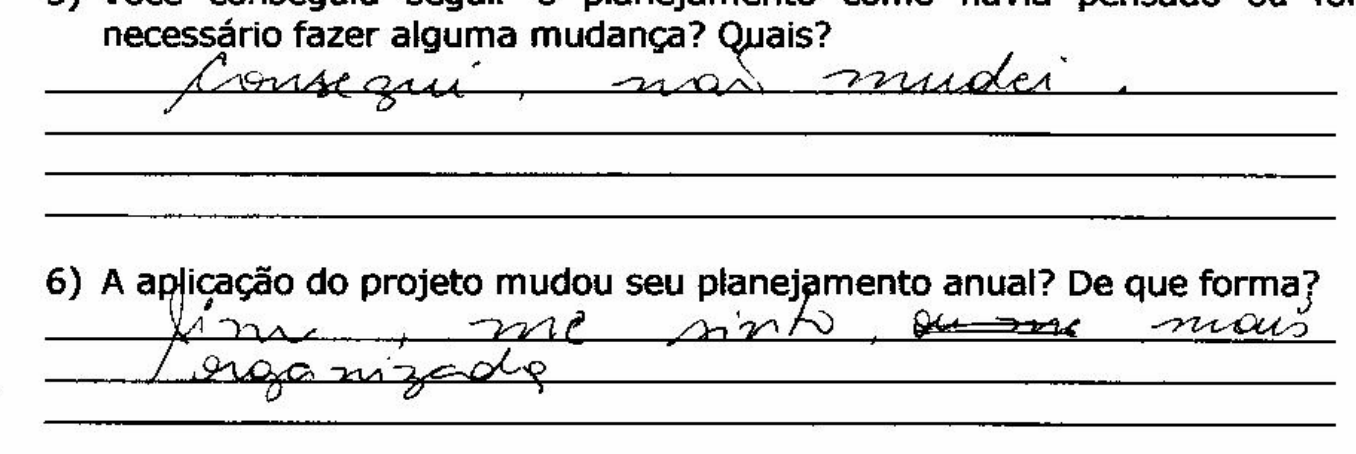

Nome (opcional): $P 2$ 


\section{QUESTIONÁRIO SOBRE O PLANEJAMENTO (ENCONTRO 22/09/2005)}

1) Vocâ já conseguiu aplicar o projeto? Se não, porquê?

\section{Nás}

2) Para aplicar o prgjeto, foj elaborado um planejamento?

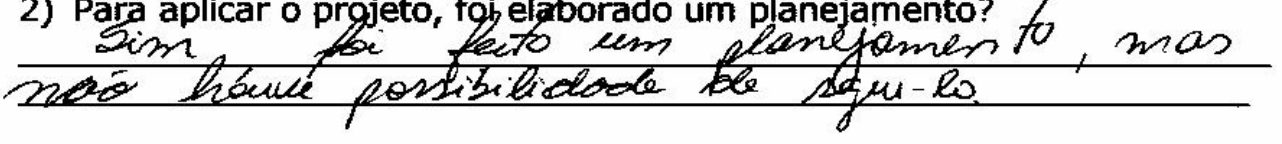

3) Você sentiy dificuldades para fazer este planejamento? Quais?

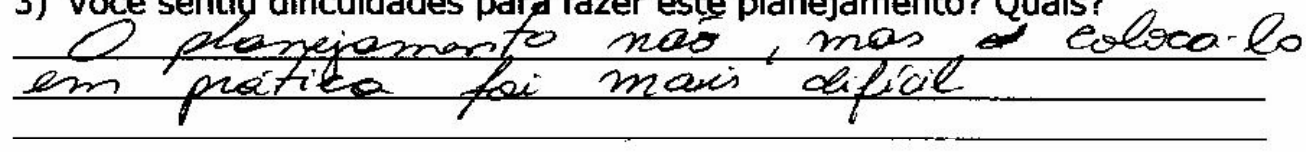

4) Este planejamento facilitou a aplicação do projeto? Explique. Sim

5) Você conseguiu seguir o planejamento como havia pensado ou foi necessário fazer alguma mudança? Quais?

Hecue necessielabe de algumos medoncens.

6) A aglicação do projeto mudou seu planejamentg anual? De que forma? im, algumes pulas foram dediea-
das paro o projeto.

Nome (opcional): _ $\quad P 4$ 


\section{QUESTIONÁRIO SOBRE O PLANEJAMENTO (ENCONTRO 22/09/2005)}

1) Yocê já conseguiu aplicar o projeto? Se não, porquê? Sirm.

2) Para aplicar o projeto, foi elaborado um planejamento? Sim

3) Você sentiu dificuldades para fazer este planejamento? Quais? Sim.

4) Esste planejamento facilitou a aplicação do projeto? Explique.

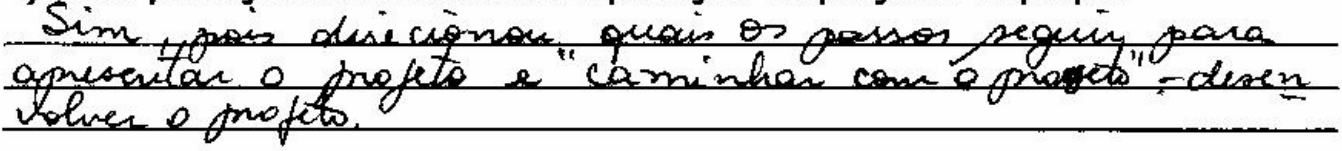

5) Você conseguiu seguir o planejamento como havia pensado ou foi necessário fazer alguma mudança? Quais?

Fi necessario mudancas onincigalmente come relacas ao tempe de pesquisa e realizacas das encomendas

6) A aplicação do projeto mudou seu planejamento anual? De que forma? Parcialmente pais os alunos estas deseruolvenoto an simulacós con o tema solucón que faz parte do plang mento, is conceitos estas, sendó tabalhedos de forma um pouco

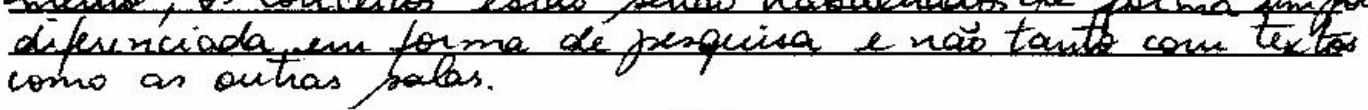

Nome (opcional): 


\section{QUESTIONÁRIO SOBRE O PLANEJAMENTO (ENCONTRO 22/09/2005)}

1) Você já conseguiu aplicar o projeto? Se não, porquêtêtaḉs fim prevén nem todas los istar concluídas.

2) Para aplicar o projeto, foi elaborado um planejamento?

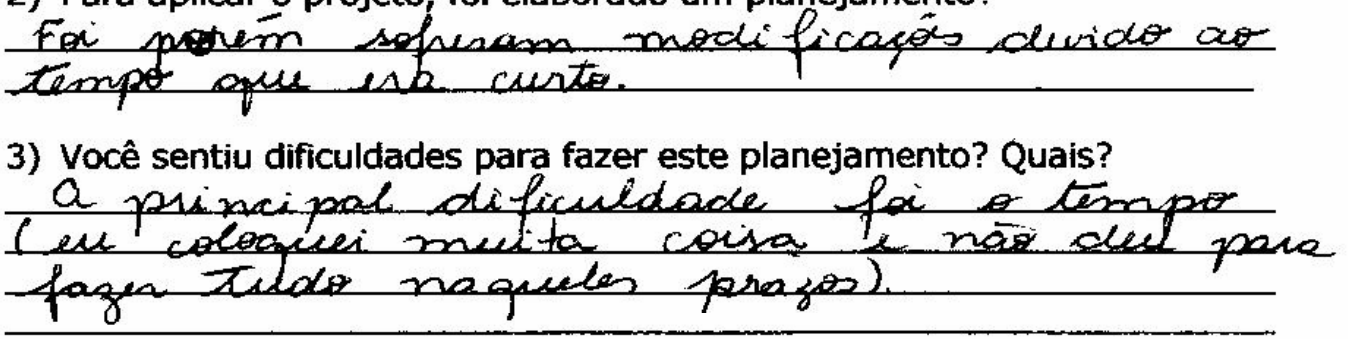

4) Este planejamento facilitou a aplicação do projeto? Explique.

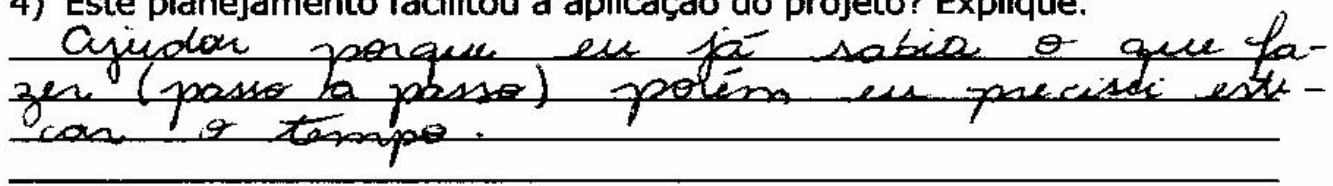

5) Você conseguiu seguir o planejamento como havia pensado ou foi necessário fazer alguma mudança? Quais?

Foi nerestín aumentas o peńrodo pa-

6) A aplicação do projeto mudou seu planejamento anual? De que forma?

Mudou alguma coina ponque en pre-
cisei fican main tempo tratando

Nome (opcional): -1 


\section{QUESTIONÁRIO SOBRE O PLANEJAMENTO (ENCONTRO 22/09/2005)}

1) Você já conseguiu aplicar o projeto? Se não, porquê?

Oá apliquei, umas nas eonsegui seter simulaeps. Fur muito critica. Trares na próaina resunias.

2) Para aplicar o projeto, foi elaborado um planejamento? Sein.

3) Você sentiu dificuldades para fazer este planejamento? Quais? sini. Rom relacts as tempo previoto.

4) Este planejamento facilitou a aplicação do projeto? Explique.

Facilitar, mas ocorren vericis altenacpés devido
a cautros projetos a pragos excistentes ma
escola.

5) Você conseguiu seguir o planejamento como havia pensado ou foi necessário fazer alguma mudança? Quais? mas; modifiquei e tempo, retomei o assunto,

6) A aplicação do projeto mudou seu planejamento anual? De que forma?, Mudou. Nuer planejamento foi madado tambón for causa do projeto. Eston atrasada.

Nome (opcional):

$P 7$ 